\title{
TOWARD A NEW HISTORY OF AMERICAN ACCIDENT LAW: CLASSICAL TORT LAW AND THE COOPERATIVE FIRST-PARTY INSURANCE MOVEMENT
}

\author{
John Fabian Witt
}

\section{TABLE OF CONTENTS}

I. RETHINKING THE ORIGINS OF AMERICAN ACCIDENT LAW .....................................699

A. Accident Law's Late Nineteenth-Century Origins.........................................................699

B. Explaining the Development of American Accident Compensation Law.......................704

C. Contingency and the Comparative Perspective ….......................................................707

D. The Comparative Perspective in Late Nineteenth-Century America ........................... 7 10

II. Amputee Workingmen, Destitute Widows, AND the Crisis

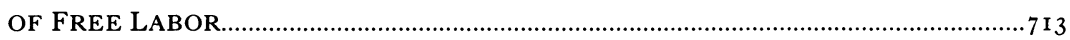

A. The Late Nineteenth-Century Accident Crisis ............................................................ 713

B. Amputee Workingmen, Destitute Widows, and the Crisis of Free Labor ..................... 722

I. The Multiple Ideals of Free Labor ......................................................................722

(a) The Liberal Ideal of Autonomy ......................................................................723

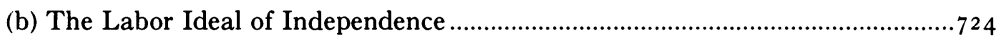

2. The Dilemmas of Free Labor .............................................................................

3. Industrial Accidents and the Dilemmas of Free Labor...........................................726

(a) Accidents and the Liberal Ideal of Autonomy ………………….......................729

(b) Accidents and the Iniquities of Competitive Wage Labor Capitalism................729

(c) Accidents and the Crisis of the Family Wage ...................................................730

C. Alternative Legal Approaches and the Accident Crisis.............................................. 732

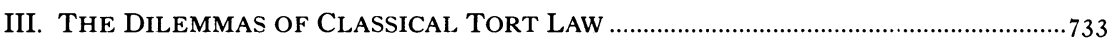

A. Classical Legal Thought and the Law of Torts...............................................................735

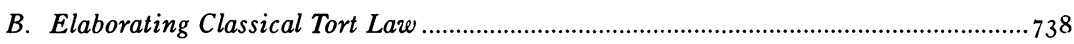

I. Damnum Absque Injuria: Defining the Bounds of Rights and Duties ....................738

2. Contributory Negligence ……….......................................................................74

3. Assumption of Risk .............................................................................................744

C. Pressure from Below: The World of Accident Litigation and the Rise of

Faultless Injuries................................................................................................. 745

I. From Loss of Services to Loss of Wages: The Transformation of the Personal Injury Suit ......................................................................................... 746

2. Obstacles to Personal Injury Litigation (I): Persistent Patterns of

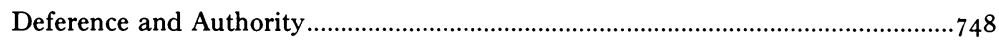

3. Obstacles to Personal Injury Litigation (II): The Law of Evidence..........................753

4. The Rise of Personal Injury Litigation and the Personal Injury Lawyer ...............758

5. The Rise of Faultless Injuries and the Compensation Crisis .................................766

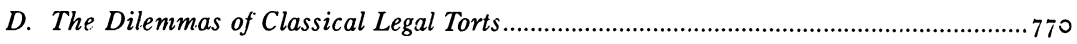

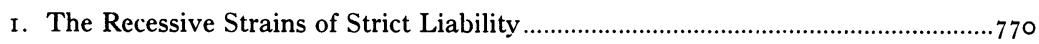




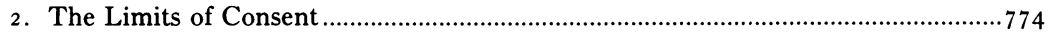

IV. THE FIRST FIRST-PARTY INSURANCE SYSTEM .........................................................777

A. Cooperative First-Party Insurance and Insurance Markets .......................................779

B. Insurance Associations and the Cooperative Strand of Free Labor Ideology.............78 $\mathrm{I}$

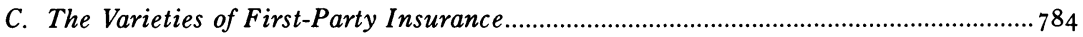

I. Commercial Life Insurance ........................................................................... 785

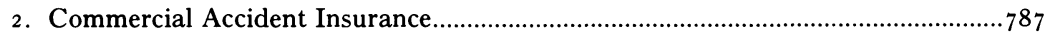

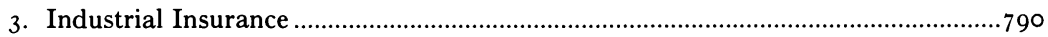

4. Trade Union Insurance Plans ........................................................................ 79 I

V. CoOperative Self-INSURANCE AND THE CoOperative CRITIQUe of

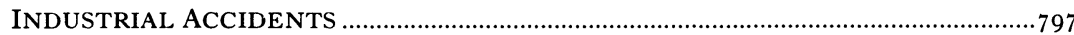

A. Cooperative Associations as Accident Insurance Mechanism ....................................797

I. The Incidence of Cooperative Insurance ..................................................................797

2. Cooperative Life and Disability Benefits ...........................................................799

3. The Structure of Cooperative Disability and Life Insurance: Moral

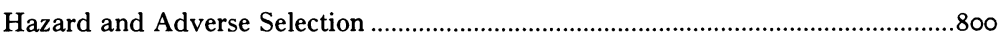

4. Ethnic, Racial, and Religious Segregation in Cooperative Insurance....................804

B. Industrial Accidents, Cooperative Associations, and the Crisis of Free-

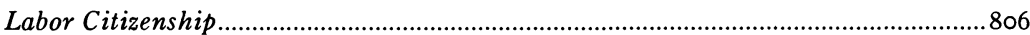

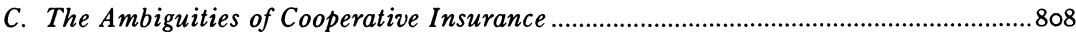

I. The Thin Theory of Cooperation: Cooperative Insurance and the Responsible Self

2. The Thick Theory of Cooperation: Cooperative Insurance and the Cooperative Commonwealth of the Workingman.................................................8 12

(a) The Cooperative Critique of the Wage System .............................................8 12

(b) Cooperative Insurance and the Critique of the Accident Crisis ......................8 $1_{5}$

3. The Ambivalences of Cooperative Insurance............................................................8 I9

D. The Unraveling of Cooperative Fraternal Insurance ................................................82 I

I. The Shortcomings of Cooperative Insurance Societies: High-Risk Exclusions .....82 I

2. Low-Risk Flight, Lapses, and Ponzi Schemes........................................................82 2

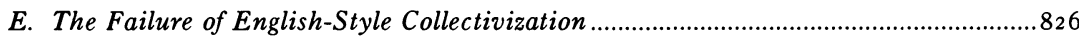

I. The Quest for 'One National Organization' ..........................................................826

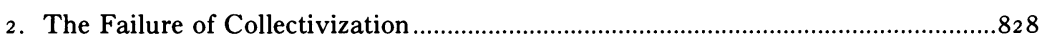

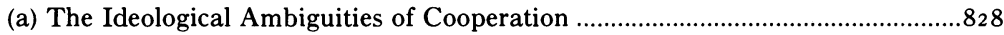

(b) The Law of the Cooperative Insurance Contract .........................................829

(c) The New Immigrants .........................................................................................8 8 I

(d) The Transformation of Work, the Deterrence Problem, and the Decline of the First First-Party System ...........................................................833

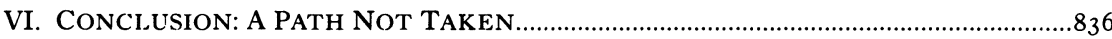




\title{
TOWARD A NEW HISTORY OF AMERICAN ACCIDENT LAW: CLASSICAL TORT LAW AND THE COOPERATIVE FIRST-PARTY INSURANCE MOVEMENT
}

\author{
John Fabian Witt*
}

$\mathrm{T}$ here are two strange discontinuities in accounts of the history of American accident law. First, the historical literature's narrow focus on the common law of tort contrasts sharply with the eclectic approach of contemporary accident law scholars. Contemporary accident law debates offer a wide array of policy alternatives to tort litigation. To name only some of the most prominent, scholars have proposed increased reliance on first-party insurance, ${ }^{1}$ various no-fault insurance schemes, ${ }^{2}$ markets in unmatured tort claims, ${ }^{3}$ and expanded state compensation plans for accidents beyond the sphere of work accidents. ${ }^{4}$ Similarly, recent descriptions of our contemporary accident law system characterize it as made up of a number of different kinds of institutions, ranging from tort law to private and public insurance

* Law Clerk to Judge Pierre N. Leval, U.S. Court of Appeals for the Second Circuit; Ph.D., J.D., Yale University. Many thanks to Miriam Aukerman, Ariela Dubler, Barry Friedman, Lawrence Friedman, Glenda Gilmore, Risa Goluboff, Bob Gordon, Henry Hansmann, Bill LaPiana, Troy McKensie, Bill Nelson, Annie Murphy Paul, John Reid, Peter Schuck, Reva Siegel, Howard Venable, and the members of the N.Y.U. Legal History Colloquium for helpful comments and insights on various versions of this Article. Bob Gordon and Reva Siegel's legal history seminar and the Yale Law School Center for Law, Economics, and Public Policy summer brown bag lunch group helpfully entertained early drafts of this Article. The Samuel I. Golieb Research Fellowship in Legal History at N.Y.U. provided invaluable institutional support.

1 See, e.g., George L. Priest, The Current Insurance Crisis and Modern Tort Law, 96 YALE L.J. I52 I, 1550-63 (1987) [hereinafter Priest, Current Insurance Crisis] (arguing that the source of the "liability crisis" of the late I980s was the shift from first-party insurance to third-party insurance); George L. Priest, Understanding the Liability Crisis, in NEW DIRECTIONS IN LIABILITY LAW I96, 207-09 (Walter Olson ed., I988) (same); see also Patrick Atiyah, Personal Injuries in the TwentyFirst Century: Thinking the Unthinkable, in WRONGS AND REMEDIES IN THE TWENTY-FIRST CENTURY I, 33-46 (Peter Birks ed., I996) (advocating the replacement of tort for personal injury with market mechanisms, primarily first-party insurance).

2 See Robert E. KeEton \& JefFrey O'CONNEll, BASIC PROTECTION For THE TRAFFiC VICTIM: A BLUEPRINT FOR REFORMING AUTOMOBILE INSURANCE (I965).

3 See Robert Cooter \& Stephen D. Sugarman, A Regulated Market in Unmatured Tort Claims: Tort Reform by Contract, in NEW DIRECTIONS IN LIABILITY LAW, supra note I, at I74. For a critical review of contract-based proposals for reforming American accident law, see Mark Geistfeld, The Political Economy of Neocontractual Proposals for Products Liability Reform, 72 TEX. L. REV. 803 (I 994).

4 See, e.g., Stephen D. Sugarman, Doing AWay with Personal Injury LaW (1989); Richard L. Abel, $A$ Critique of Torts, 37 UCLA L. REV. 785, 822-25 (I990); Marc A. Franklin, $R e-$ placing the Negligence Lottery: Compensation and Selective Reimbursement, 53 VA. L. REV. 774, 808-I 4 (I 967). 
programs to no-fault compensation schemes. ${ }^{5}$ Yet histories of American accident law are remarkable for the absence of alternative models. Indeed, the singular feature of our accounts of the development of American accident law is their central concern, one might say obsession, with the tort case. ${ }^{6}$

Second, the history of accident law in the United States is usually recounted as separate and apart from the main currents of the political and legal history of the nineteenth and twentieth centuries. ${ }^{7}$ To be sure, the great waves of industrialization in the American economy have always been, and will surely always remain, a central interpretive tool in explaining changes in the nineteenth- and twentieth-century

5 See Kenneth S. Abraham \& Lance Liebman, Private Insurance, Social Insurance, and Tort Reform: Toward a New Vision of Compensation for Illness and Injury, 93 COLUM. L. REV. 75 (I993); Richard B. Stewart, Crisis in Tort Law? The Institutional Perspective, 54 U. CHI. L. REV. I84 (I987). For a similar description of the English accident compensation system, see P.S. Atiyah, ACCidents, COMPENSATION AND THE LAW 389-4I 2 (2d ed. I975). For an account of the recent history of academic theorizing about alternatives to tort law, see Gary T. Schwartz, Foreword: Tort Scholarship, 73 CAL. L. REV. 548 (I 985 ).

6 There is a growing scholarly literature using historical data to weigh the virtues and flaws of alternative legal regimes. But these studies are not as interested in explaining the development of American accident law as they are in debating the efficiency of various liability regimes. See Price V. Fishback \& ShaWn Everett Kantor, A Prelude to the Welfare State: The ORIGINS OF WORKER'S COMPENSATION (2000); MICHAEL J. MOORE \& W. KIP VISCUSI, COMPENSATION MECHANISMS FOR JOB RISKS: WAGES, WORKERS' COMPENSATION, AND PRODUCT LiABILITY (I990); James R. Chelius, Liability for Industrial Accidents: A Comparison of Negligence and Strict Liability Systems, 5 J. LEgAL STUD. 293 (1976); Price V. Fishback \& Shawn Everett Kantor, Did Workers Pay for the Passage of Workers' Compensation Laws?, I I0 Q.J. ECON. 713 (1995); Price V. Fishback, Liability Rules and Accident Prevention in the Workplace: Empirical Evidence from the Early Twentieth Century, I6 J. LEGAL STUD. 305 (I987).

7 Morton Horwitz's account of tort, contract, and property in the antebellum period pioneered the approach to writing the history of private law fields such as torts as central to political history broadly construed. See MORTON HORWITZ, THE TRANSFORMATION OF AMERICAN LAW, i 780I860 (I977) [hereinafter HORWITZ, TRANSFORMATION I]. Horwitz's interpretation of tort law in the late nineteenth century, however, focuses on intellectual currents in tort law theory rather than on the role of tort law in the great social struggles of the day. See MorTon Horwitz, The TRANSFORMATION OF AMERICAN LAW, I870-1960: THE CRISIS OF LEGAL ORTHODOXY (I992) [hereinafter HORWITZ, TRANSFORMATION II]. In addition, there is an exciting and still-growing body of work that seeks to bring accident law to the forefront of scholarly inquiry into legal and social change in the nineteenth and early twentieth centuries. See, e.g., CHRISTOPHER L. TOMLINS, LAW, LABOR, AND IDEOLOGY IN THE EARLY AMERICAN REPUBLIC 223-92 (I 993) (arguing that the law of work-related accidents gave shape to the Foucauldian disciplinary relationship between employers and employees in the emerging industrial econon $\rightarrow$ Arthur F. McEvoy, The Triangle Shirtwaist Factory Fire of I9II: Social Change, Industrial Accidents, and the Evolution of Common-Sense Causality, 20 LAW \& SOC. INQUIRY 62 I (I995) (identifying the Triangle Shirtwaist Fire as a catalyst for changes in broad ideas about social causation at the turn of the century); Jonathan Simon, For the Government of Its Servants: Law and Disciplinary Power in the Work Place, 1870-1906, I3 STUD. L. POL. \& Soc'Y 105 (19! $\rightarrow$ Barbara Y. Welke, Unreasonable Women: Gender and the Law of Accidental Injury, 1870-1920, I9 LAW \& SOC. INQUIRY 369 (I994). 
law of torts. ${ }^{8}$ Nonetheless, tort law exists only at the margins of our histories of the great battles to define the character of industrializing America. Labor movement opposition to the spread of wage labor, struggles between capitalists and laborers in the workplace, and the political groundswell of farmers' and agrarian parties have been the central themes of the histories of the critical half century following the end of the Civil War, and these themes have rarely included debates and struggles over the law of accidents. Instead, accident law has generally been treated as a player at the edges of a great conflict. Tort law, our histories assume, is not about the structure of the underlying economic system, but rather about addressing the messy by-products of that system. In our own time, after all, most scholars and policymakers view accident law as an instrument to facilitate market economies by minimizing the economic costs of accidents. ${ }^{9}$ And so, scholars often look back and see in past tort regimes the same approach. ${ }^{10}$ At the very least, scholars tend to assume that accident law did not implicate the basic structures of political and social life. Thus the histories of the main currents of American political and social history make the tacit claim that the way in which the law dealt with the accidents produced by capitalism had little to do with the ongoing struggles over the legitimacy of the capitalist system itself. For the story of that struggle, our histories look elsewhere.

This Article seeks to redress these two disjunctures in the history of American accident law. In the second half of the nineteenth century, the United States experienced an accident crisis like none the world had ever seen and like none any Western nation has witnessed since. By the turn of the century, one worker in fifty was killed or disabled for at least four weeks each year because of a work-related accident. ${ }^{11}$ In the population as a whole, roughly one in every thousand Americans died by accident each year. ${ }^{12}$ In dangerous industries, accident rates were considerably higher. In I 890 alone, one railroad worker in

8 See, e.g., LAWrence M. Friedman, A History OF AMERICAN LAW 467 (2d ed. I985) ("The modern law of torts must be laid at the door of the industrial revolution, whose machines had a marvelous capacity for smashing the human body.").

9 The foundational works in the modern economic approach are GUIDO CALABRESI, THE Costs of ACCIDENTS: A LEgal AND Economic ANALYSis (1970); and Richard A. Posner, ECONOMIC ANALYSIS OF LAW (5th ed. 1998). There are, of course, competing views of tort law. Even critics of the economic-instrumentalist view, however, concede its dominance in current debates. See, e.g., Ernest J. Weinrib, Understanding Tort Law, 23 VAL. U. L. REV. 485, 488 (I989) ("So ingrained is the dominance of instrumentalist tort theory that an alternative approach is now scarcely imaginable.").

10 The classic example is Richard A. Posner, A Theory of Negligence, I J. LEGAL STUD. 29 (1972).

11 Frederick Hoffman, Industrial Accident Statistics, BUll. U.S. BUREAU OF LABOR STAT., March I9I5, at 5-6.

12 Id. at 13. 
every three hundred was killed on the job; among freight railroad brakemen, one in every hundred died in work accidents each year. ${ }^{13}$ The most extraordinary rates of death and injury appear to have been reached in the anthracite coal mines of Pennsylvania, where each year during the I860s and I870s six percent of the workforce was killed, six percent permanently crippled, and six percent seriously but temporarily disabled. ${ }^{14}$ By comparison to other Western economies, accident rates in the late nineteenth- and early twentieth-century United States were remarkably high. Railroad fatalities, for example, were four times more frequent per train-mile in the United States than in England. ${ }^{15}$ And by comparison to today, rates of accidental death at the turn of the century were astronomical. The annual accidental death rate of one in one thousand for the population as a whole in the United States in 1900 is as great as that of the single most dangerous occupation (lumber and timber work) at the opening of the twenty-first century. ${ }^{16}$ Today, fewer than four in every ten-thousand Americans die each year from accidents. ${ }^{17}$

Americans in the last decades of the nineteenth century experimented with a number of alternative institutional mechanisms for dealing with the problem of industrial accidents. The common law of torts emerged in these years - for the first time - as an accident law regime. Workers organized widespread but remarkably little-known cooperative insurance societies. Many employers - especially in the first decade of the twentieth century - adopted private employer compensation programs. Social insurance advocates supported accident compensation schemes such as the workmen's compensation statutes that were enacted in the decade after r9io and that appeared likely at the time to develop into much broader social insurance programs. ${ }^{18}$

Moreover, each of the different institutional experiments in the late nineteenth century embodied not just a distinct solution to the industrial accident crisis, but also a competing vision of how best to reor-

13 Mark Aldrich, SAFETy First: Technology, LABOR, AND Business IN THE BuILdING OF AMERICAN WORK SAFETY, I870-I939, at I5-I6 (I997).

14 Anthony F.C. Wallace, St. Clair: A Nineteenth-Century Coal Town's ExPERIENCE WITH A DISASTER-PRONE INDUSTRY 253 (I987).

15 ALDRICH, supra note $\mathrm{I}_{3}$, at $\rightarrow$ Carroll W. Doten, Recent Railway Accidents in the United States, 9 PUbliCATIONS AM. STAT. AsS'N i 55, I67 (1905).

16 ALDRICH, supra note $\mathrm{I}_{3}$, at 5 ; supra p. 694.

17 Centers for Disease Control and Prevention, Dep'T of Health \& Human ServS., NATIONAL VITAL STATISTICS REPORTS, July 24, 2000, at 26 tbl.8, available at http://www.cdc.gov/ nchs/data/nvs48_i I.pdf [hereinafter NATIONAL VITAL STATISTICS REPORTS].

18 For a review of the alternative approaches to accident law during the late nineteenth and early twentieth centuries, see John Fabian Witt, The Accidental Republic: Amputee Workingmen, Destitute Widows, and the Remaking of American Law, I868-1922 (2000) (unpublished Ph.D. dissertation, Yale University) (on file with the Harvard Law School Library). 
ganize nineteenth-century institutions for the twentieth-century industrial economy. The employer-specific accident compensation programs that grew quickly after the turn of the century, for example, advanced a managerial-corporatist approach to the accident problem, in which employers and managers took private responsibility for the governance of social life. ${ }^{19}$ Workmen's compensation programs, on the other hand, represented the first step toward a broad statist approach to the reorganization of accident law. ${ }^{20}$

This Article focuses on the contrast between the common law of torts and the cooperative insurance societies of American workingmen. Lawyers and judges constructed the common law of torts as an attempt to contain the fallout from the industrial economy within the framework of classical liberalism. The cooperative insurance societies, by contrast, advanced a critique of competitive capitalism; to its proponents, cooperative self-insurance against accidents stood as a model for the cooperative reconstruction of American economic life.

The Article first describes the structure of the common law of torts as an elaborate working-out of the principles of classical nineteenthcentury liberalism. The finely wrought doctrinal structures of the common law of torts, however, ultimately failed to contain the late nineteenth-century accident crisis. In part, the common law of torts failed because it was an immensely inefficient and costly mechanism for resolving accident cases - a mechanism that proved inadequate to compensate accident victims and their families. In another sense, however, the failure of the common law of tort was rooted in the conceptual dilemmas posed for classical nineteenth-century liberalism by the accidents of the industrial revolution.

The Article then turns to the rise and fall of the most important but virtually ignored late nineteenth-century alternative to tort law: the cooperative first-party insurance movement. After the Civil War, cooperative insurance societies became the earliest American first-party system of compensation for accidental injury and death. Indeed, by the late nineteenth-century, workingmen's insurance societies became the leading systematic mechanism for compensating victims of accidental injury, and they remained such into the first decade of the twentieth century. The cooperative societies thus represent a critically

19 A few legal scholars - mostly of an economic bent - have written, about the employers' compensation programs. See, e.g., Richard A. Epstein, The Historical Origins and Economic Structure of Workers' Compensation Law, I6 GA. L. REV. 775, 797-800 (I982) (discussing the adoption of private compensation schemes by English firms); Price V. Fishback \& Shawn Everett Kantor, The Adoption of Workers' Compensation in the United States, 1900-1930, 4I J.L. \& ECON. 305 (1998).

20 See, e.g., Roy Lubove, The STRUgGle FOR Social Security, i 900-i 935, at 45-65 (2d ed. I 986$)$. 
important path not taken by American accident law, one that has been virtually written out of the histories of tort law. In particular, the insurance associations presented a remarkably well designed insurance mechanism that developed novel solutions to the moral-hazard and adverse-selection problems endemic to disability insurance. Moreover, the cooperative insurance societies embodied a radical critique of the competitive capitalist system that generated industrial accidents in the first place. As we shall see, this cooperative critique was itself fraught with internal contradictions and tensions. Nonetheless, the cooperative insurance associations represented America's leading model of cooperative economic organization. And in the eyes of the leaders of the late nineteenth-century movement to recreate American capitalism on a cooperative basis, the societies formed the opening wedge for the cooperative transformation of American economic life.

This Article thus claims that the history of American accident law is a story of sharply divergent normative conceptions of political economy. Our own accident law regime today is in large part the product of the contest among these different visions of accident policy, and indeed, different visions of American politics and society more generally. Accordingly, understanding how we have arrived at the accident law regime that we have today requires reconstructing the alternate possible paths of development with which Americans experimented over a century ago.

The reconstruction of one such path not taken in accident law at the turn of the twentieth century begins to explain some of the peculiar characteristics of the American tort system today. In most other Western nations, social insurance programs provide a much higher share of accident victim compensation than they do in the United States. The American accident law regime in the early twenty-first century, by contrast, is characterized by relatively greater reliance on costly tort litigation that leaves victims undercompensated, does a poor job of deterring accidents, and satisfies few of its constituencies other than the lawyers who profit from it. The story of the rise and fall of the first first-party insurance system is a history of the demise of our earliest attempt to experiment with alternatives to the tort system. In Great Britain, as we shall see, the friendly societies - cooperative insurance associations much like their American counterparts described here were incorporated into early state insurance schemes and played an important role in the construction of a more systematic disability insurance regime. American cooperative self-insurance societies also sought to develop into a quasi-public apparatus for disability insurance. But the decline and ultimate demise of cooperative insurance societies in the United States blunted the possibility of the development of a broader social insurance approach to accident compensation in the early twentieth century. 
Part I of the Article sets the stage for what is to come by describing and critiquing the existing histories of American accident law. By thinking comparatively about the histories of American accident law and accident law in Western Europe, I argue that existing histories of the law of accidents in the United States - notwithstanding their diversity - share the common flaw of viewing the development of accident law as having flowed ineluctably from either changes in the underlying economy, on the one hand, or changes in ideas about such concepts as causation or the nature of legal science, on the other. Comparative studies of Western nations undergoing similar economic and intellectual changes, however, indicate that other nations experimented with a wide array of alternative accident law regimes. American accident law reformers in the I880S and I890s knew of the various European models for accident law, and in fact studied them quite closely. As a result, the shape of American accident law in the late nineteenth century was more radically contingent than existing accounts suggest.

Part II turns to the particular ideological and cultural setting in which Americans approached the late nineteenth-century accident problem. In particular, a loose collection of ideas about the meaning of free labor manhood in the post-Civil War economy distinguished the American experience from that of other nations and established the basic terms on which the American debate about accident law took place.

Part III describes the emergence of the common law of torts as an attempt by American judges and lawyers to grapple with the accident problem in the terms of classical liberalism. Part IV then turns to the leading late nineteenth-century alternative to the common law of torts: first-party or self-insurance against disability and death. First-party disability and life insurance in the late nineteenth century took a number of different forms, and Part IV discusses several of the leading insurance mechanisms. Cooperative self-insurance societies, however, best solved the problems endemic to disability insurance markets. As a result, cooperative first-party insurance against disability and death quickly emerged as the leading form of first-party insurance, and indeed as the leading systematic mechanism for compensating accident victims in the late nineteenth century and into the twentieth.

Part V examines the cooperative insurance movement in more detail and describes it as an ingenious solution to a number of the problems that to this day plague private disability insurance mechanisms. As we shall see, the disability insurance market innovations developed by the cooperative associations became increasingly difficult to implement in the twentieth century. Thus notwithstanding the genius of cooperative insurance as a mechanism for providing disability and life insurance in the late nineteenth century, the cooperative first-party insurance associations do not appear to have had a long-term future as a 
private first-party insurance alternative to tort law. Instead, the longterm viability of the cooperative insurance movement rested on the possibility that the American societies could, like their European counterparts, become the building blocks of early social insurance programs.

Ultimately, of course, the cooperative insurance movement failed to make the transition to social insurance, and Part VI examines the causes of its decline. Nonetheless, at the turn of the twentieth century, American insurance cooperatives - like their counterparts across the Atlantic - had established the foundations of a system of accident law very different from the one we have today.

\section{RETHINKING THE ORIGINS OF AMERICAN ACCIDENT LAW}

\section{A. Accident Law's Late Nineteenth-Century Origins}

Modern accident law is a remarkably recent development. Indeed, the American system of accident law is almost entirely a product of the late nineteenth and early twentieth centuries, for it was only then that the accident rates of an industrializing economy required the development of new institutions to deal with the fallout from regular injury and accidental death.

Eighteenth-century lawyers and judges in England and in the American colonies focused little attention on the law of tort. William Blackstone's monumental four-volume treatise on the English common law, published between I 765 and I 769 , was largely concerned with the technicalities of real property law. For example, Blackstone's treatment of "private wrongs," as close as he came to the modern concept of torts, was cursory and wholly unconcerned with the substantive law of torts that would come to preoccupy twentieth-century lawyers. ${ }^{21}$ Early and mid-nineteenth-century American lawyers and judges, in turn, reorganized the law around the principle of contract. ${ }^{22}$ Private contractual relations became the paradigmatic concept through which common law lawyers and judges approached legal problems, and lawyers treated as contracts cases many disputes that would be considered

21 See 3 WILliam BlaCKSTONE, COMMENTARIES * I I 5-43.

22 See HORWITZ, TRANSFORMATION I, supra note 7, at I60-2 io ("The Triumph of Contract"). This reorganization was primarily a Northern phenomenon; the nature of Southern states' legal systems is a matter of some controversy among historians because the law of slavery generated a powerful set of noncontractual guiding principles. Compare MARK V. TUSHNET, THE AMERICAN LAW OF SLAVERY, I8Io-I860: CONSIDERATIONS OF HUMANITY AND INTEREST 33-34 (I98I) (arguing that the law of slavery reinforced a paternalistic worldview), with JENNY BOURNE WAHL, THE BONDSMAN'S BURDEN: AN ECONOMIC ANALYSIS OF THE COMMON LAW OF SOUTHERN SLAVERY (I998) (redescribing Tushnet's ostensibly paternalistic legal rules as designed to effectuate efficient transactions in the peculiar kind of property that was the slave). 
torts problems today. ${ }^{23}$ To be sure, wide swaths of the mid-nineteenthcentury common law were inconsistent with a contractual theory of social relations. Noncontractual status relationships characterized the relations of husband and wife and master and servant, to name two central social institutions. ${ }^{24}$ At the same time, a robust tradition of public regulation of social life persisted alongside the rhetoric of contractualization..$^{25}$ States and municipalities governed communities through the power of eminent domain, ${ }^{26}$ the regulation of marriage and sexuality, ${ }^{27}$ the policing of labor relations, ${ }^{28}$ the regulation of public markets via the police power, ${ }^{29}$ and innumerable other spheres of regulation..$^{30}$ Nonetheless, judges, lawyers, and legal scholars marginalized these noncontractual aspects of American law in favor of the organizing principle of contract.

To say that the categories of property and contract dominated the legal discourse, however, is not to say that there was no concept of legal liability for nonconsensual harm in the American legal system prior to the late nineteenth century. The basic principle of legal recompense for harm is an ancient one. Sociologists in the Weberian tradition, for instance, have long argued that the ancient state originated not in contract, as Locke and Hobbes argued, but rather in tort. ${ }^{31}$ On this account, payment of damages through a centralized institution replaced

23 On the role of contract-based approaches to accident cases in the mid-nineteenth century (as well as continued reliance on property concepts), see Robert L. Rabin, The Historical Development of the Fault Principle: A Reinterpretation, I5 GA. L. REV. 925 (I98I); see also HORWITZ, TRANSFORMATION I, supra note 7, at 209-IO.

24 See Karen ORRen, Belated Feudalism: LABOR, THE LAW, AND Liberal DevelopMENT IN THE UNITED STATES I60-208 (I99I); TOMLINS, supra note 7, at 232-58; Reva B. Siegel, The Modernization of Marital Status Law: Adjudicating Wives' Rights to Earnings, 1860-1930, 82 GEO. L.J. 2 I 2 7, 2 I 33-4I (I994).

25 See generally William J. Novak, The People's Welfare: LAW AND Regulation IN NINETEENTH-CENTURY AMERICA (1996) (identifying an American tradition of public regulation in the nineteenth century).

26 See Carol Rose, The Comedy of the Commons: Custom, Commerce, and Inherently Public Property, 53 U. CHI. L. REV. 7 I I, 749-53, 77 I-74 (1986); Harry N. Scheiber, Public Rights and the Rule of Law in American Legal History, 72 CAL. L. REV. 2 I $7,225-27$ (I984).

27 See Hendrik Hartog, MAN AND Wife IN AMERICA: A History (2000); Ariela R. Dubler, Governing Through Contract: Common Law Marriage in the Nineteenth Century, IO7 YALE L.J. I885, I885-86 (1998); Reva B. Siegel, "The Rule of Love": Wife Beating as Prerogative and Privacy, IO5 YALE L.J. 2 I I 7, 2 I I 9-20 (I996).

28 See TOMLINS, supra note 7.

29 See, e.g., NovaK, supra note 25, at 83-I I3; Hendrik Hartog, Pigs and Positivism, I985 WIS. L. REV. 899.

30 Examples include usury, bankruptcy, corporations, the creation of banks, and the common law of competition. For a classic overview, see JAMES WILLARD HURST, LAW AND THE CONDITIONS OF FREEDOM IN THE NINETEENTH-CENTURY UNITED STATES (I956).

31 See 2 MAX Weber, ECONOMY AND SOCIETY 904-Io (Guenther Roth \& Claus Wittich eds., I978). 
clan vengeance as the mechanism for making amends for injury. ${ }^{32}$ And indeed, the Code of Hammurabi, written sometime around the year 2000 B.C.E., included a schedule of damages that an injurer had to pay to the injured, as did the early Roman Twelve Tables. ${ }^{33}$ Aristotle's account of corrective justice and the law in the Nicomachean Ethics required the restoration of the status quo ante in the event of what he called "involuntary" transactions. ${ }^{34}$ Classical Roman law, too, had an ad hoc collection of rules for compensatory justice in instances of bodily injury, rules that had evolved out of the early practice of buying off family vengeance. ${ }^{35}$ And by the early modern period, such civil law scholars as Hugo Grotius distilled from the collection of Roman law rules governing private wrongs a single standard of civil liability for "fault," by which Grotius meant action or inaction "in conflict with what men ought to do."36

Yet the problem of compensation for accidental human injury caused by the regular operations of economic life was new to Western legal systems in the mid- to late nineteenth century. Aristotle discussed his conception of corrective justice not in relation to accidental injury but in relation to intentional acts "such as assault, imprisonment, murder, robbery with violence, mutilation, abuse, insult." 37 Even as late as I 88I, the future Justice Holmes, like Aristotle more than two thousand years before, had no conception of the special problems raised for the law of torts by a society facing the statistical inevitability of accidental injury from economic activity. According to the views expressed in Holmes's The Common Law, liability could only be imposed on those who could foresee the possibility of injury and yet still chose to go ahead with the injury-creating activity. ${ }^{38}$ If applied at a high enough level of generality, of course, this liability standard could have been applied to industrial activities. Under modern industrial conditions, after all, a certain number of injuries will follow predictably from a

32 See id.

33 James Q. Whitman, At the Origins of Law and the State: Supervision of Violence, Mutilation of Bodies, or Setting of Prices?, 7 I CHI.-KENT L. REV. 4I, 49-53 (I995).

34 When "one has received and the other has inflicted a wound, or one has slain and the other been slain," Aristotle explained, "the suffering and the action have been unequally distributed; but the judge tries to equalize things by means of the penalty, taking away from the gain of the assailant." 4 ARISTOTle, NiCOMACHEAN ETHicS, Bk. V, ch. 4, in INTroduction to ARistotle 308, 405 (W.D. Ross trans., Richard McKeon ed., I947).

35 See F.H. LAWSON, NEgLigenCE IN THE Civil LAW I-29 (I950).

36 Id. at 28 .

37 ARISTOTLE, supra note 34, at Bk. V, ch. 2. I do not mean to say that the Aristotelian concept of corrective justice is inapplicable to unintentional harms, but merely that Aristotle's central concern appears to have been intentional acts.

38 See Oliver Wendell Holmes, The Common LaW 92 (Belknap Press I 983) (1881). 
decision to proceed with a particular economic activity. ${ }^{39}$ Yet Holmes developed his theory of torts not around industrial injury cases but around personal interactions. Thus, for Holmes - or at least for the Holmes of $188 \mathrm{I}$ - the famous case of Brown v. Kendall, ${ }^{40}$ in which one man accidentally struck another with a stick while striking a dog, became the paradigm case for a theory of torts. ${ }^{41}$

Even as Holmes formulated his early theory of torts, however, the development of industrial manufacturing and railroads was undermining his view of the proper role of foresight and choice in tort doctrine. Indeed, Holmes's early account of the nature of tort law was remarkably out of touch with the emerging world of tort litigation. In

39 See DAVId RosenberG, THE Hidden Holmes: His TheORY OF TORTS IN HISTORY, I08o9 (I995).

4060 Mass. (6 Cush.) 292 (1850).

41 See HOLMES, supra note 38 , at $84-85$. Building on Holmes's support for the strict-liability theory of Rylands v. Fletcher, I L.R.-Ex. 265 (I866), David Rosenberg has recently argued that Holmes's theory of torts is best understood as having advocated a foresight-based strict-liability theory. See ROSENBERG, supra note 39. Rosenberg's interpretation is provocative, and it has the great benefit of unsettling stale and anachronistic assumptions about Holmes's thinking. But much of it is difficult to square with the historical record. As Rosenberg explains, Holmes defended the Rylands decision, which held a nonnegligent defendant liable for damages from water from a reservoir that flooded a neighboring mine, on the ground that the foreseeably risk-prone choice of the defendant had been made "further back" in time, when he chose to have an extrahazardous reservoir on his property. See HOLMES, supra note 38 , at 157 . On Rosenberg's view, the removal back in time of the critical moment of choice and foresight is theoretically consistent with a relatively broad view of enterprise liability for injuries incurred in the course of industrial life. See ROSENBERG, supra note 39, at 135 . But in $\mathrm{I} 88 \mathrm{I}$, as Rosenberg concedes, see id. at I 34 , Holmes showed little awareness of the possible application of his theory of torts to the accidents of an industrializing era; he certainly showed no interest in applying the removed foresight test to industrial enterprise. Instead, Holmes appears to have treated foreseeable but nonnegligent injuries as falling into the category of damnum absque injuria: injuries without remedies. See Holmes, supra note 38 , at I 15 ("There are certain things which the law allows a man to do, notwithstanding the fact that he foresees that harm to another will follow from them."); see also Robert W. Gordon, Holmes' Common Law as Legal and Social Science, Io HoFSTRA L. REV. 719, 736-37 (1982). The law of torts, by Holmes's lights, properly followed a policy of "protecting trade" rather than "protecting titles." HOLMES, supra note 38 , at 80 . Accordingly, Holmes's proposed foreseeability standard closely resembled the modern negligence standard in its utilitarian social welfare calculation: "[T]he public generally profits from individual activity. As action cannot be avoided, and tends to the public good, there is obviously no policy in throwing the hazard of what is at once desirable and inevitable upon the actor." Id. at 77. Even if Rosenberg's foresight-based strict liability approach had been Holmes's approach, such a foresight-based approach would have been open to widely varying determinations of liability depending on (I) the temporal remove at which the judge or scholar made the foresight determination, and (2) the level of generality at which the judge or scholar pitched the required foreseeability of the consequences. Judges who required relatively immediate foreseeability rather than remote foreseeability, or who required that consequences be foreseeable with particularity, would have been able to create an extremely narrow liability regime that could have insulated industrial enterprise from the costs of injuries. On the bench, Holmes appears to have been precisely such a judge. See G. EDWARD WHITE, JUSTICE Oliver Wendell Holmes: LAW AND THE INNER SELF 264-72 (1993); Mark Tushnet, The Logic of Experience: Oliver Wendell Holmes on the Supreme Judicial Court, 63 VA. L. REV. 975, 1030-33 (1977). 
an industrial enterprise of the late nineteenth century, it could be said with some certainty that there would be injuries to workers; on a railroad, for example, it was wholly foreseeable that there would necessarily be a certain number of accidental injuries to passengers and employees. Injury in these circumstances was statistically inevitable, yet railroads and manufacturing enterprises chose (and chose reasonably, by most measures) to go forward with their operations anyway. And according to Holmes and his contemporaries on the bench, the mere fact of that decision was hardly sufficient to charge them with liability in the event of accidents that were not foreseeable in their particulars. ${ }^{42}$

Thus, in the years between the Civil War and the end of the century, a new accident problem pushed tort law to the fore for the first time as a central problem in the American legal order. Accident rates increased dramatically. Personal injury litigation developed and litigation rates skyrocketed. For the first time, middle- and working-class people purchased life insurance policies on a widespread basis. Newly established accident insurance companies wrote a new kind of policy for railway passengers. And legal scholars developed a discrete field known as "tort law." Boston lawyer Francis Hilliard's I 859 treatise on torts, though still framed in Blackstone's terms as a treatise on "private wrongs," 43 was, as Hilliard observed in his preface, the first work exclusively devoted to the law of torts. ${ }^{44}$ Within a decade, Harvard Law School added a course on torts to its curriculum, ${ }^{45}$ and within another twenty years law libraries swelled with new treatises on torts and related fields like railroad and insurance law. ${ }^{46}$ Indeed, within two decades of his I88I lectures on the common law, Holmes was compelled to rethink his ideas about negligence, foreseeability, and choice in light of the statistical inevitability of accidents in modern life. Whereas in I88I he had been preoccupied with interpersonal torts re-

42 See HolmES, supra note 38 , at 95.

43 BLACKSTONE, supra note $2 \mathrm{I}$, at $*$ I I5-43.

44 See i Francis Hilliard, The LaW of Torts, or Private Wrongs, at iii (Boston, Little, Brown \& Co. 1859).

45 See C.G. Addison, The Law of Torts, Abridged for Use in the LaW School of HARVARD UNIVERSITY (Boston, Little, Brown \& Co. 1870).

46 See, e.g., JAMES BARR AMES, Select CASES ON TORTS (Cambridge, i874); Melville M. BIGELOW, ELEMENTS OF THE LAW OF TORTS FOR THE USE OF STUDENTS (Boston, Little, Brown \& Co. 1878); George Bliss, JR., The LaW OF LIFE INSURANCE WITH Chapters UPON ACCIDENT AND GUARANTEE INSURANCE (New York, Baker, Voorhis \& Co. I872); FREDERICK H. COOKE, THE LAW OF LIFE INSURANCE INCLUDING ACCIDENT INSURANCE AND INSURANCE BY Mutual Benefit Societies (New York, Baker, Voorhis \& Co. i89i); ThOMAS M. CoOley, A TREATISE ON THE LAW OF TORTS OR THE WRONGS WHICH ARISE INDEPENDENT OF CONTRACT (Chicago, Callaghan \& Co. I879); William B. HALE, HANDBOOK ON THE LAW OF TORTS (St. Paul, West Publ'g Co. i896); ThOmas G. Shearman \& Amasa A. Redfield, A Treatise on THE LAW OF NEGLIGENCE (New York, Baker, Voorhis \& Co. I869). 
sulting from chance occurrences, in 1897 he observed that the "torts with which our courts are kept busy to-day are mainly the incidents of certain well known businesses. They are injuries to person or property by railroads, factories, and the like." ${ }_{47}$ These injuries, thrown off by the seemingly inexorable progress of industry, created the accident law dilemmas of the late nineteenth and early twentieth centuries.

\section{B. Explaining the Development of American Accident Compensation Law}

The sudden development of accident law in the mid- to late nineteenth century has long presented an attractive subject for historical explanation. Yet the dominant historical accounts of the rise of American accident law fail to recognize the extent to which the late nineteenth century was a moment of possibility for alternate paths of development.

Existing histories of the development of American accident law may be divided roughly into two kinds of accounts: materialist and idealist. ${ }^{48}$ The materialist accounts explain changes in the law of personal injury as responses to industrialization. The standard story in the historical literature begins in a pre-industrial era often supposed to have been characterized by strict liability to injurers for harm inflicted on victims. ${ }^{49}$ The old common law writ of trespass, on this view, provided victims of personal injury (as well as victims of any number of different kinds of injury to personal or real property) a means to recover for harm inflicted, whether or not the injurer acted negligently.50 Trespass thus protected a static conception of the social order by requiring corrective justice in instances of violation of the status quo. ${ }^{51}$ This conventional materialist story continues into the dawn of the in-

47 Oliver Wendell Holmes, Jr., The Path of the Law, Io HARV. L. REV. 457, 467 (I897).

48 A third historical approach focuses not on explaining change in the law of torts but rather on describing the substantive content of tort law. The leading example is Rabin, supra note 23. There is, of course, considerable overlap among the two categories identified in the text and this third category. A fourth category might be said to exist in the fledgling attempts to develop a Foucauldian disciplinary theory of the law of torts. See, e.g., ToMLINS, supra note 7; Jonathan Simon, For the Government of its Servants: Law and Disciplinary Power in the Workplace, 1870-1906, I3 STUD. L. POL. \& SOC'Y IO5 (I993).

49 See Horwitz, TRANSFORMation I, supra note 7; Charles O. Gregory, Trespass to Negligence to Absolute Liability, 37 VA. L. REV. 359 (I95 I). The strict liability thesis about the earlymodern law of accidents has been widely attacked. See, e.g., PETER KARSTEN, HEART VerSUS HEAD: JUDGE-MADE LAW IN NINETEENTH-CENTURY AMERICA 8I-85 (I997); Gary T. Schwartz, Tort Law and the Economy in Nineteenth-Century America: A Reinterpretation, 90 YALE L.J. I 7 17, I722-34 (1981).

50 The writ of trespass, however, required plaintiffs to show that the harm occurred directly as a result of the defendant's actions rather than indirectly.

51 See FRIEDMAN, supra note 8, at 299-300; HORWITZ, TRANSFORMATION I, supra note 7, at 35-36; Gregory, supra note 49, at 36I-62; Leon Green, The Duty Problem in Negligence Cases: II, 29 COLUM. L. REV. 255, 255 (1929) ("A feudal economy required a morality of trespass ...."). 
dustrial era, when the strict liability standard of the writ of trespass is said to have given way to a relatively restrictive negligence principle that underwrote industrial development. ${ }^{52}$ Where once the common law had enforced a corrective justice approach to departures from the status quo, now tort rules encouraged economic development by allowing enterprises to shift the cost of injury-producing activity onto workers, passengers, and neighboring property owners. Thus, midnineteenth-century tort law generally attached liability only upon a finding of negligence on the part of the defendant and developed a series of defenses that often allowed even negligent defendants to escape liability. The doctrine of contributory negligence barred recovery for those whose own negligence contributed to their injury; the doctrine of assumption of risk denied recovery to injured employees on the ground that they assumed the ordinary risks of accidents in the workplace; the fellow servant rule provided immunity to employers in cases in which employee negligence caused the injury of a fellow worker. Then, in the last years of the nineteenth century and the first years of the twentieth, growth in the rate of accidents and the new maturity of the United States's industrialized economy gave rise to an expansion in tort liability. ${ }^{53}$ In the final stage of the materialist account, when tort liability threatened to become too great, states adopted workmen's compensation statutes at the behest of employers to limit employee recovery in work accident cases. ${ }^{54}$

Idealist accounts of the development of accident compensation law tell a similar story but explain historical change by reference to developments in the history of ideas or the sociology of knowledge rather than developments in the economy. Under this approach, the crystallization of the negligence principle in nineteenth-century tort law is said to have arisen not out of the developmental imperatives of an industrializing economy, but rather out of the efforts of the late nineteenthcentury American legal profession to reconceptualize legal rules as a set of ordered and scientific principles. ${ }^{55}$ Jurists like Holmes took it

52 See FRIEDMAN, supra note 8, at 300-02; HORWITZ, TRANSFORMATION I, supra note 7, at 85I08; Gregory, supra note 49 , at 368,382 . Like the thesis that the eighteenth-century law of torts was characterized by a strict liability rule, the story of the rise of a restrictive negligence principle has also been challenged. See, e.g., KARSTEN, supra note 49, at 8-15, 79-127; Schwartz, supra note 49, at $1727-34$.

53 See Lawrence M. Friedman \& Jack Ladinsky, Social Change and the Law of Industrial Accidents, 67 COLUM. L. REV. 50, 59-60 (1967).

54 For materialist accounts of the adoption of workmen's compensation statutes, see ROY Lubove, The STRUgGLe FOR SOCIAL SECURITY, 1900-i 935, at 45-65 (1968); JAMES WEINSTEIN, THE CORPORATE IDEAL IN THE LIBERAL STATE, I900-I9I8, at 40-6I (I968); Friedman \& Ladinsky, supra note 53 , at 69-72.

55 See G. EDWARD White, TORT LAW IN AMERICA: AN INTELLECTUAL HistORY I2-I9 (1980). A less sophisticated idealist account is presented in KARSTEN, supra note 49, at 79-127. Karsten argues that mid-nineteenth-century tort doctrine was inherited by American judges who 
upon themselves in these years to bring conceptual order and theoretical cohesion to the jumble of legal doctrines that comprised the early nineteenth-century law of torts. The negligence principle arose as the leading candidate for doctrinal conceptualists like Holmes because it satisfied the conceptualist desire to unify and systematize tort law at an exceedingly high level of generality around a single abstract principle. ${ }^{56}$ Thus, rather than an ad hoc collection of relational standards, the law of tort instead consisted of one duty of care that each individual owed to all the world. ${ }^{57}$ Furthermore, the idealist approach holds that the shift from a narrow mid-nineteenth-century regime of liability for negligence to a twentieth-century regime of liberalized liability for accidents arose out of new developments in intellectual history. Thus, for example, it is said that widening conceptions of causation, responsibility, and interdependence prompted lawyers and judges to expand the scope of liability. ${ }^{58}$

were constrained by English precedents and the "taught legal tradition." Id. at 79. He explains changes in tort doctrine in the later in the century as the result of judicial sympathy (the "heart" rather than the "head") for the plight of injured plaintiffs. See id. at I9I-29I. A more persuasive account along similar lines is presented in Comment, The Creation of a Common Law Rule: The Fellow Servant Rule, I837-I860, I32 U. PENN. L. REV. 579, 598-600 (1984) (arguing that the fellow servant rule spread across American jurisdictions because of judges' ideas about the meaning of ordered and rational precedent). Another article in this loose cluster of "idealist" accounts is Alfred S. Konefsky, "As Best to Subserve Their Own Interests": Lemuel Shaw, Labor Conspiracy, and Fellow Servants, 7 LAW \& HIST. REV. 2 19, 233-35 (1989), which advances an ideological explanation of the fellow-servant rule as grounded in republican thought. See also Paul Finkelman, Slaves as Fellow Servants: Ideology, Law, and Industrialization, 3I AM. J. LEGAL HIST. 269, 283-85 (1987) (providing an ideological account of the distinct rules for personal injuries sustained by hired-out slaves in the antebellum South). Earlier idealist accounts explain the development of the negligence principle as part of a general evolution in the law from amoral standards of strict liability to rules that looked to the ethics of a defendant's behavior. See, e.g., James Barr Ames, Law and Morals, 22 HARV. L. REV. 97, 98-99 (1908).

56 WHITE, supra note 55, at 4-I9.

57 See Oliver Wendell Holmes, Jr., The Theory of Torts, 7 AM. L. REV. 652, 660 (I873); ADDISON, supra note 45, at iii ("The Law of Torts is the law of those rights which avail against persons generally, or against all mankind, as distinguished from the law of those rights which avail against particular persons ...."). As Robert Rabin has pointed out, whether late nineteenthcentury lawyers conceived of the negligence principle as attaching universally to social relations, the fact remains that the law of torts was shot through with special relational standards, and even included large areas of what Rabin rightly calls zones of "no-duty." Rabin, supra note 23 , at 928.

58 RANDOLPH BERGSTROM, COURTING DANGER: INJURY AND LAW IN NEW YORK CITY, I870-1910, at $167-96$ ( 1992 ) (attributing the rapid growth in personal injury litigation in turn-ofthe-century New York City to a "change of mind" regarding responsibility and causation); LAWRENCE M. FRIEDMAN, TOTAL JUSTICE 45-76 (I985) (locating the twentieth-century growth of American tort law in a new "general expectation of justic $\rightarrow$ McEvoy, supra note 7 , at 627 ; William E. Nelson, From Fairness to Efficiency: The Transformation of Tort Law in New York, 1920-1980, 47 BUFF. L. REV. I I7, I30-32 (1999) (arguing that early twentieth-century New York tort principles manifested a new conceptualization of causation, responsibility, and fairness, and explaining changes in mid-twentieth-century tort law by reference to the development of new ideas about accident preventability); Daniel Polisar \& Aaron Wildavsky, From Individual to System Blame: A Cultural Analysis of Historical Change in the Law of Torts, I J. POL'Y HIST. I 29 (I989) (correlating 


\section{Contingency and the Comparative Perspective}

Recent scholarship foreshadows the beginnings of new approaches to the history of American accident law. Arthur McEvoy, for example, argues that particular dramatic events such as the Triangle Shirtwaist fire of I9II decisively changed the course of accident law reform. ${ }^{59}$ And Barbara Welke contends that as more women encountered accidental injury and death, ideas about gender helped to shape the law of torts even as those ideas about gender were themselves constructed and reconstructed in railroad accident litigation. ${ }^{60}$

Yet despite the glimmerings of new approaches on the horizon, the standard materialist and idealist accounts remain the dominant stories of the history of American accident law. Neither approach offers a persuasive account of the development of accident law, however, for neither approach adequately grasps the contingency of the American accident law regime. ${ }^{61}$ Both materialist and idealist approaches generally assume that there is a determinate relation between a particular course of social change (industrialization) or a new intellectual development (changing ideas about causation), and a particular regime or doctrinal structure in accident law. Such an assumption might be plausible within the narrow confines of the common law of torts. Wider conceptions of causation, for example, might expand the number of persons who could be said to have proximately caused a particular injury. ${ }^{62}$ And as noted at the outset, the existing literature on the development of late nineteenth-century American accident law is in fact preoccupied with problems arising in traditional common law tort cases. By focusing on tort doctrine and tort cases, however, schol-

personal injury litigation patterns with conceptions of responsibility and blame); see also THOMAS L. Haskell, The Emergence of Professional Social SCIEnCE: The American Social SCIENCE ASSOCiation AND THE NineteEnTH-CENTURY CRISIS OF AUTHORITY 240-56 (I977) (describing changing ideas about causation in late nineteenth-century America).

$59 \rightarrow$ McEvoy, supra note 7 , at 626 .

$60 \rightarrow$ Welke, supra note 7 , at 397-98; see also Margo Schlanger, Injured Women Before Common Law Courts, 1860-1930, 2 I HARV. WOMEN's L.J. 79, I39 (1998) (concluding that judges in torts cases carved out specially tailored rules to accommodate the social circumstances of women plaintiffs). In many respects, this Article carries forward the gendered interpretations of Schlanger and especially Welke, except that the approach here focuses on the gendered nature of accident cases involving men. The great bulk of accident cases involved men, and in particular men injured at work. As we shall see, injuries to workingmen generated crises for ideas both of independent manliness and of dependent Victorian womanhood in late nineteenth-century American society. $\rightarrow$ Welke, supra note 7 , at 37 I (noting that a gendered analysis of accident law could be applied equally to men as to women).

61 This point is sketched in summary fashion in Robert W. Gordon, Tort Law in America: An Intellectual History, 94 HARV. L. REV. 903, 907 (I98I) (reviewing WHITE, supra note 55). See also Robert W. Gordon, Critical Legal Histories, 36 STAN. L. REV. 57, I 25 (1984).

62 Cf. HASKell, supra note 58, at 240-56; Thomas L. Haskell, Capitalism and the Origins of Humanitarian Sensibility, Parts I and II, in The ANTISLAVery Debate 107, 107-60 (Thomas Bender ed., I992). 
ars have missed the dynamic and highly contingent character of American accident law in these years. The United States and other industrializing nations experimented in the late nineteenth and early twentieth centuries with an array of policy alternatives to address the problem of compensation for accident victims, and the existence of alternatives to tort litigation ruptures the neat relation between particular social or intellectual developments and changes in the accident law system. Social or intellectual developments could have produced an expanded doctrine of proximate cause, but they could also have produced - and indeed, did produce - any number of alternative responses, such as novel insurance mechanisms, new private contractual arrangements, and state compensation systems. ${ }^{63}$

A simple comparative examination of Western accident law suggests the wide array of alternatives in play during the late nineteenth century and dispels the notion of a clear relation between industrialization or changing ideas of causation, on the one hand, and a particular regime of accident law, on the other. The United States, after all, was not alone in facing an unprecedented challenge to its legal institutions. In the mid-nineteenth century, industrialized countries in Western Europe experienced similar growth in accident rates, though never quite as dramatically as the United States. Yet despite undergoing very similar processes of industrialization and roughly analogous intellectual developments, Western European nations developed accident law regimes quite different from the legal regime of the mid- and late nineteenth-century United States.

Germany offers the most striking contrast to the development of American accident law. As in the United States, industrialization came later to Germany than to England. ${ }^{64}$ Yet although its pattern of industrialization resembled that of the United States, Germany's accident law took a very different path. Germany moved to a regime of strict liability for the most important categories of accidents just as the United States and England were generalizing the negligence principle. In 1838 , the Prussian Railway Act created a presumption of railroad

63 Thomas Grey argues persuasively in a forthcoming article that even the structure of the common law of tort could have developed in radically different directions in the years after the Civil War. See Thomas C. Grey, Accidental Torts, 54 VAND. L. REV. (forthcoming 200I).

64 Feudal institutions and early-modern craft guilds continued to dominate the economies of most German states in the early nineteenth century. In the decades after I848, however, the German economy underwent extraordinarily rapid growth and industrialization. ALAN S. MILWARD \& S.B. SAUL, THE ECONOMIC DEVELOPMENT OF CONTINENTAL EUROPE, I 780-1870, at 367 (2d ed. I979); W.W. Rostow, The STAGES OF ECONOMIC GROWTH: A NON-COMMUNIST MANIFESTO 38 (I960); see DAvid S. LANDES, The Unbound PRometheus: Technological Change and INDUSTRIAL DEVELOPMENT IN WESTERN EUROPE FROM I 750 TO THE PRESENT I93-230 (I 969 ). 
liability for injuries arising out of railroad accidents. ${ }^{65}$ And by the late I85os, local Prussian districts had established a welter of compulsory welfare plans for miners (Knappschaften) and other industrial workers (Unterstutzungskassegesetz), which provided medical care and financial support for the victims of industrial accidents. ${ }^{66}$ Germany followed Prussia's lead after the unification of the German Reich in I87I and adopted the Prussian rule of a presumption of strict liability for railroad accidents, supplemented by a new vicarious liability rule for workplace accidents arising out of negligence in factories and in other dangerous non-railroad employments. ${ }^{67}$ Then in 1884 Germany adopted the first strict-liability workmen's compensation program, replacing cumbersome accident litigation with more efficient, streamlined administrative processes and limited damages. ${ }^{68}$ To be sure, some forty years later, American jurisdictions developed workmen's compensation programs that drew on the German model. But whereas state compensation programs in the United States remained limited to workplace accidents, ${ }^{69}$ Germany expanded on its workmen's compensation model to develop social welfare programs such as sickness and health insurance that created broad guarantees of compensation for disability more generally. ${ }^{70}$

English accident compensation law provides another contrast with the American system. Tort law scholars have long observed that many late nineteenth-century American courts rejected particular English tort doctrines, such as the rule of strict liability for certain hazardous

65 Andre Tunc, Torts, in i I INTERnational EnCyClopedia of Comparative LaW, \& I-80, at 46 (1975); John G. Fleming, Tort Liability for Work Injury, in I 5 INTERNATIONAL ENCYCLOPEDIA OF COMPARATIVE LAW, $\$ 9-47$, at 33-34 (1975). The railway company could free itself of liability "only by showing either that the damage was due to the injured person's own fault or that it was caused by an unavoidable, external accident." Tunc, supra, at 46.

66 E.P. HeNNOCK, BRITISH SOCIAL REFORM AND GeRMAN PRECEDENTS: THE CASE OF SOCIAL INSURANCE, I880-I9I4, at 43 (I987); GERHARD A. RITTER, SOCIAL WElfare IN GERMANY AND BRITAIN 2 I-22 (Kim Traynor trans., I986); GEORGE STEINMETZ, REGULATING THE SOCIAL: THE WELFARE STATE AND LOCAL POLITICS IN IMPERIAL GERMANY I 26-27 (I993).

67 See Tunc, supra note 65, at 46-47.

68 See STEINMETZ, supra note 66, at I27-28; see also GASTON V. RIMLINGER, WELFARE POLICY AND INDUSTRIALIZATION IN EUROPE, AMERICA, AND RUSSIA 90-130 (I97I); RITTER, supra note 66, at 32-82; Detlev Zollner, Germany, in THE EvOLUTION OF SOCIAL INSURANCE I88I-198I: STUDIES OF GERMANY, FRANCE, GREAT BRITAIN, AUSTRIA AND SWITZERLAND I, 22-28 (Peter A. Kohler \& Hans F. Zacher eds., I982).

69 Exceptions include relatively narrow cause-based compensation programs, such as the Black Lung Benefits Program, the National Vaccine Injury Compensation Program, and state programs that compensate for neurological birth defects. See Abraham \& Liebman, supra note 5, at 79.

70 Germany enacted its first sickness insurance plan in 1883 , one year before enacting its industrial accident compensation plan. See RITTER, supra note 66, at 32-82. On the extension of German state accident insurance in the early twentieth century, see id. at $83-130$; and Zollner, supra note 68 , at $32-52$. 
activities. ${ }^{71}$ In this sense, there were significant doctrinal differences between the American and English tort systems. But at a more basic structural level, the English and American compensation systems diverged sharply beginning in I897, when England adopted its own workmen's compensation program, fifteen to twenty years before most American jurisdictions. ${ }^{72}$ By the time the United States developed workmen's compensation statutes of its own, England (like Germany) had expanded the scope of its social insurance mechanisms to provide insurance coverage to accident victims outside of the workplace. ${ }^{73}$

In sum, comparable foreign jurisdictions developed very different accident compensation systems despite sharing similar economic and social histories. In the nineteenth century, Germany moved to strict liability and compulsory state compensation approaches even as the United States adopted the negligence rule. England adopted a state compensation system for work accidents earlier than the United States, and then moved decisively toward the use of social insurance mechanisms to compensate accident victims.

\section{The Comparative Perspective in Late Nineteenth-Century America}

To illustrate the inadequacy of historical accounts that draw overdetermined lessons from changes in the economy or from new ideas about causation, it would be enough to establish merely that countries undergoing similar social changes developed quite different approaches to accident law. One might still object, however, that such alternative paths were either unavailable or unknown to Americans at the time. But Americans in the late nineteenth and early twentieth centuries were in fact deeply interested in experiments in accident policy abroad. Indeed, beginning in the I880s, the cosmopolitan nature of American accident law reform debates suggests the availability of a variety of realistic alternatives.

Policymakers and academics in progressive-era America participated in a vibrant trans-Atlantic dialogue on the problems of modern

71 This doctrine is the famous rule of Rylands v. Fletcher. For the American courts' rejection of the Rylands rule, see Brown v. Collins, 53 N.H. 442, 450 (1873); and Losee v. Buchanan, 5 I N.Y. 483, 49I (1873). See generally RICHARD A. EPSTEIN, CASES AND MATERIALS ON TORTS I34-35 (6th ed. r995).

72 See P.W.J. BARTRIP \& S.B. BURMAN, THE WOUNDED SOldiERS OF INDUSTRY: INDUSTRIAL COMPENSATION POLICY I833-1897, at I90-206 (1983); DAVID G. HANES, THE FiRST BRITISH WORKMEN'S COMPENSATION ACT, I897, at 87-106 (I 968); HENNOCK, supra note 66, at 63-79; Epstein, supra note I9, at 797-800; see generally W.C. Mallalieu, Joseph Chamberlain and Workmen's Compensation, Io J. ECON. HIST. 45 (1950).

73 Most importantly, England's I9 I National Insurance Act created compulsory national health insurance. See A.I. Ogus, Great Britain, in THE Evolution OF SocIAL INSURANCE: I88I-I98I: STUDIES OF GERMANY, FRANCE, GREAT BRITAIN, AUSTRIA, AND SWITZERLAND, supra note 68 , at $150,15 \mathrm{I}-87$. 
social politics in a wide range of fields. ${ }^{74}$ Accident compensation was no exception; debates in the United States about the best course for accident policy took place in a self-consciously international conversation. The American labor movement, for example, had been aware since the mid-nineteenth century of the more favorable liability rules in European jurisdictions, and labor leaders who favored liability law reform in the 1870 s and 1880 s frequently framed their arguments for liberalized employers' liability laws in comparative terms. ${ }^{75}$ In the late I 880s, the Quarterly Journal of Economics reprinted German accident insurance statutes for its American audience. ${ }^{76}$ Other commentators carefully reviewed the viability of the German approach for U.S. accident policy. ${ }^{77}$ And by the 1890 , many American social scientists were convinced that European examples of compulsory insurance against accident and disability represented the future of American policy. ${ }^{78}$

Carroll D. Wright, Chief of the Massachusetts Bureau of Labor Statistics from I873 to I 888 and the first U.S. Commissioner of Labor from I888 until I 905 , was the first American labor reformer to engage in systematic comparative study of foreign accident regimes. ${ }^{79}$ When the Massachusetts legislature directed Wright in 1882 to investigate the subject of employers' liability, especially among railroad workers, Wright focused on the comparative study of employers' liability laws. ${ }^{80}$ Ten years later, while serving as U.S. Commissioner of Labor,

74 See generally JAMES T. KLOPPENBERg, UNCERTAIN ViCTORY: SOCIAL DEMOCRACY AND PROGRESSIVISM IN EUROPEAN AND AMERICAN THOUgHT, I870-I920 (I986); DANIEL T. Rodgers, ATlantic Crossings: Social POlitics in a Progressive AGE (I998).

75 See, e.g., The Labor Movement: The Problem OF Today 54-59 (George McNeill ed., Boston, A.M. Bridgman \& Co. I887).

76 F.W. Taussig, Workmen's Insurance in Germany, 2 Q.J. ECON. I I I (I888); An Act Concerning Insurance in Case of Disability and Old Age, 4 Q.J. ECON. I03 (I890).

77 See, e.g., B.W. Wells, Compulsory Insurance in Germany, 6 POL. SCI. Q. 43, 64 (I89I); F.W. Taussig, Workmen's Insurance in Germany, 8 FORUM I59, I69 (I889).

78 See, e.g., I 7 ANN. REP. OF THE BUREAU OF LABOR STAT. OF N.Y. I899, at 559-60, I I62 (1900) [hereinafter ANN. REP. N.Y. LABOR STAT.] (arguing that the "clear ... fact that every trade has its own inevitable risks" had led European nations to move to compulsory insurance plans and urging United States jurisdictions to abandon "the unjust provisions of the old common law"); Charles R. Henderson, Workingmen's Insurance, 4 AM. J. SoC. 695, 696 (I899); Edward Cummings, Workingmen's Insurance, $6 \mathrm{~J}$. POL. ECON. 556, 558 (1898) (reviewing WILLIAM FRANKLIN Willoughby, Workingmen's Insurance (I898)); John Cummings, Book Review, 6 J. POL. ECON. 556 (1898).

79 Wright was perhaps an unlikely candidate to bring a cosmopolitan perspective to American accident compensation. He was born in 1840 in a small New Hampshire town. After the Civil War, Wright developed a successful law practice and began a promising political career in the state senate. In 1873 , he received a political appointment as chief of the state's new labor statistics collection effort. When local Republican Party politics defeated his political aspirations in the late I870s, Wright made labor statistics his new career. See JAMES LeIBy, CARROLL Wright AND LABOR REFORM: THE ORIGIN OF LABOR STATISTICS 7-38 (I 960 ).

$80 \mathrm{See}$ I 4 ANN. REP. OF THE MASS. BUREAU OF STAT. OF LABOR I883, at 3-52 (Boston, Wright \& Potter Printing Co.) [hereinafter ANN. REP. MASS. LABOR STAT.]. 
Wright hired John Graham Brooks to write a report on German insurance schemes. ${ }^{81}$ By the end of the 1890 , Wright's continuing belief that international examples could inform American law reform led him to appoint William Franklin Willoughby as the Department of Labor's full-time representative in Europe. Willoughby proceeded to catalog the social legislation experiments of European nations in mindnumbing detail, and in I 898 he prepared a broad survey of European workingmen's insurance schemes. ${ }^{82}$ In Willoughby's view, Continental experimentation with compulsory insurance regimes, along with the proliferation of voluntary insurance programs, presented a multiplicity of possible approaches to a problem of increasingly "great practical importance" in the United States. ${ }^{83}$

Wright and his team of researchers were hardly the only students of American liability law interested in foreign examples. State bureaus of labor statistics followed Wright's example, and in the r880s and I 890 s they issued a number of comparative studies of employers' liability rules. ${ }^{84}$ Similarly, in the first decade of the twentieth century, as workmen's compensation legislation became a topic of serious discussion in American legislatures, an array of reformers and academics traveled to Europe under the aegis of such organizations as the Russell Sage Foundation, the National Association of Manufacturers, and the U.S. Department of Labor to see for themselves how other nations dealt with accident compensation. ${ }^{85}$ Moreover, such trans-Atlantic policy exchange went both ways. In the I88os, German economists

81 See John Graham Brooks, Fourth ANNUAL SPECIAL REPORT OF THE COMMISSIONER OF LABOR: COMPULSORY INSURANCE IN GERMANY INCLUDING AN APPENDIX RELATING TO COMPULSORY INSURANCE IN OTHER COUNTRIES IN EUROPE II (Washington, D.C., Gov't

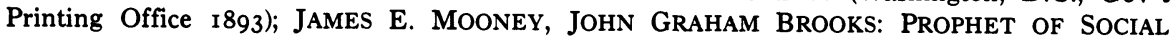
JUSTICE: A CAREER STORY 22 (1968).

82 WILliam FRANKLIN WILlOUGHBy, WORKINGMEN's INSURANCE (New York, Thomas Y. Crowell \& Co. I898). For a discussion of Willoughby's work, see RODGERS, supra note 74 , at 30 , $39,63,66$.

83 WilloughBy, supra note 82, at iii-v; see also William Franklin Willoughby, The French Workmen's Compensation Act, I2 Q.J. ECON. 398 (I898).

84 See, e.g., I I ANN. REP. OF THE BUREAU OF STAT. OF LABOR \& INDS. OF N.J. FOR THE YEAR ENDING OCT. 3I, I888 (Trenton, John L. Murphy Publishing Co. I889) [hereinafter ANN. REP. N.J. LABOR \& INDS. STAT.]; I 7 ANN. REP. N.Y. LABOR STAT., supra note 78, at 559-60, I 162.

85 See, e.g., 24 U.S. DEP'T OF LABOR, ANN. REP. OF THE COMM'R OF LABOR: WORKMEN'S INSURANCE AND COMPENSATION SYSTEMS IN EUROPE (1909) (2 vols.); LEE K. FRANKEL \& MILES M. DAWSON, WORKINGMEN'S INSURANCE IN EUROPE (IgIO) (Russell Sage Foundation study of European social insurance); FERD. C. SCHWEDTMAN \& JAMES A. EMERY, ACCIDENT PREVENTION AND RELIEF: AN INVESTIGATION OF THE SUBJECT IN EUROPE WiTh SPECIAL ATTENTION TO ENGLAND AND GERMANY (I 1 I I ) (National Association of Manufacturers study of European accident compensation programs); see also Paul Monroe, An American System of Labor Pensions and Insurance, 2 AM. J. SOC. 501 (I897). 
came to the United States to study, among other things, the accident insurance programs of American cooperative insurance societies. ${ }^{86}$

American accident law reform in the late nineteenth century was thus a remarkably cosmopolitan affair in which reformers drew on an array of different accident compensation models from Western Europe and Britain. ${ }^{87}$ For Wright, Brooks, and Willoughby, as well as for the panoply of groups that followed them, the great attraction of comparative study of accident law regimes was that it suggested a wide range of possible approaches to the problem of accidents in an industrializing society.

\section{Amputee Workingmen, Destitute WidoWs, AND THE CRISIS OF FREE LABOR}

\section{A. The Late Nineteenth-Century Accident Crisis}

Before turning to some of the different accident law regimes with which Americans experimented in the post-Civil War years, we need to take fuller account of the underlying accident problem. As we have seen already, Western industrializing nations developed a number of different responses to the accident compensation problem of the nineteenth century. But it is not surprising that Germany, England, and the United States each developed new accident compensation schemes during roughly the same years in the mid- to late nineteenth century. For though the accident problem was especially acute in the United States, most Western economies faced a similar problem: the explosion of accident rates in societies that were rapidly becoming urban and industrial.

To a certain extent it was the specter of modern warfare that forced industrializing nations to develop new institutions and policies to deal with injury, disability, and death. In the United States in particular, the ghastly toll of the Civil War highlighted the need to address the fallout from disability and death in an era of new technologies for causing injury. Not counting deaths from disease and sickness, I00,000 Union soldiers were killed in battle during the war, as were at

86 See August Sartorius von Waltershausen, THE WORKers' MOVEMENT IN THE UNITED STATES, I879-I 885, at I 7 I-2 I 9 (David Montgomery \& Marcel van der Linden eds., I 998) (I 885).

87 For further American discussions of accident compensation framed as comparative studies, see I.M. Rubinow, Labor Insurance, I2 J. POL. ECON. 362, 375-78 (1904); and Adna F. Weber, Employers' Liability and Accident Insurance, I 7 POL. SCI. Q. 256, 26 I-83 (I902). 
least 50,000 Confederate soldiers; 88 members of the Union Army alone suffered 400,000 nonfatal wounds and injuries. ${ }^{89}$

The unprecedented onslaught of human injury made a lasting impression on the men and women who witnessed it.90 Watching the fighting at the First Battle of Bull Run in I86I, one Union nurse wrote that the sight of the battlefield was "perfectly appalling." Men lay "bleeding, torn and mangled; legs, arms and bodies are crushed and broken as if smitten by thunderbolts." 11 Frederick Law Olmsted, working for the United States Sanitary Commission, recorded the waves of wounded and sick he witnessed while organizing hospital transports during the I862 Peninsula Campaign. The "wounded," he wrote, poured in "by every train," "packed as closely as they could be stowed in the common freight cars"; "[t]hey arrived, dead and alive together, in the same close box, many with awful wounds festering and alive with maggots." "The stench," Olmsted reported, "was such as to produce vomiting." 92 In the same year, an eyewitness to the horrific violence at Antietam recorded having seen "the most appalling sights upon the battlefield." The ground was "strewn with the bodies of the dead and the dying." "[P]iles of dead men" revealed the "writhing agony in which they died," with "arms and legs torn from the body or the body itself torn asunder." 93

Wartime casualties generated a vigorous effort to organize effective delivery of medical care to wounded and sick soldiers on the battlefield. The Sanitary Commission, a semipublic body of volunteers, inspected medical facilities and operated battlefield ambulance and triage operations in the hopes of creating a "grand system of sanitary care and succor in the Federal army." Medical Department was slow to develop the organizational coherence necessary to deal effectively with the unprecedented number of inju-

88 Horace Herndon CunNingham, Doctors in GraY: The Confederate MEdical SERVICE 5 (I 958 ).

89 GeORge Worthington Adams, Doctors in Blue: The Medical History of The UNION ARMY IN THE CIVIL WAR 3 (I952).

90 As Allan Nevins put it in his classic account of the Civil War, Americans by 1863 had come to realize that no recent conflict "had cost so much in life ... as this one threatened to cost." 3 AllaN NEVINS, THE WAR FOR THE UNION: THE ORGANIZED WAR I863-I864, at 3 (I97 I).

91 Emma E. Edmonds, July 21, I86I, in CIVIL WAR MEDICINE: CARE \& COMFORT OF THE WOUNDED 34 (Robert E. Denney ed., I 994). The thunderbolt analogy is particularly striking. The causes of the battlefield devastation, of course, were all too human. Nonetheless, Edmonds conceived of the causes as acts of god rather than acts of men.

924 THE Papers OF FREDERICK LAW OlMSTED, Defending THE UNION: THE Civil WaR AND THE U.S. SANITARY COMMISSION, I86I-I863, at 363 (Jane Turner Censer ed., I 986 ).

93 I BERNARd BaILyN, Robert Dallek, DAVId BRION DAVIS, DAVID HERBERT DONALD, JOHN L. THOMAS \& GORDON S. WOOD, THE GREAT REPUBLIC: A HISTORY OF THE AMERICAN PEOPLE 6I6-I 7 (I992).

94 U.S. SANITARy COMm'N, THE SANITARy COMmission OF THE UNITED STATES ARMY: A SUCCINCT NARRATIVE OF ITS WORKS AND PURPOSES iii (n.p., I864). 
ries, by the end of the war Union doctors were experimenting with new methods of sanitation, hygiene, and treatment. ${ }^{95}$

The Civil War even gave rise to the United States's first major experiment in public policy for disability and injury in peacetime. For many veterans, of course, wartime injuries remained disabling well after the war itself had ended. Thus, in the wake of the war, the federal government developed institutions and programs designed to reintegrate the injured Civil War veteran into postwar society. The National Home for Disabled Volunteer Soldiers, created just before the end of the war, sheltered veterans whose medical conditions and economic circumstances required inpatient care; by I900, the National Home had housed a total of nearly 100,000 Union veterans. ${ }^{96}$ Moreover, the system of Civil War pensions provided aid to tens of thousands of disabled veterans in the years after the war. ${ }^{97}$ To be sure, Civil War pensions and veterans' homes never expanded to encompass disabled citizens generally. And by the last years of the nineteenth century, the veterans' pension program had devolved into a corruption-laden spending program with little connection to disability policy. ${ }^{98}$ Yet the Civil War veterans' programs presaged the emergence of a series of attempts to deal with the growing problem of accidents in late nineteenth-century American civilian life. Indeed, in the first decades of the twentieth century, the Civil War veterans' programs would lay the groundwork for accident compensation policies aimed at the nation's beleaguered industrial army.

Even in peacetime, however, the process of industrialization generated an unprecedented problem of accidental death and injury in Western economies. Thus, although the Civil War's role in generating a new set of ideas and attitudes about the problem of bodily injury ought not be underestimated, observers of the industrial scene in the I 880 s were struck by the fact that the peacetime economy produced more death and injuries than the war that preceded it. ${ }^{99}$

95 See ADAMS, supra note 89, at I98-99; see also FRANK R. FREEMON, GANGRENE AND GLORY: MEDICAL CARE DURING THE AMERICAN CIVIL WAR I66-80 (I998). On the Confederate Army's medical care, which was hamstrung by a lack of resources, see CUNNINGHAM, supra note 88, passim.

96 Patrick J. Kelly, Creating a National Home: Building the Veterans' Welfare STATE I860-I 900 , at 2 (I997).

97 Theda Skocpol, PROTecting Soldiers and Mothers: The Political Origins of SOCIAL POLICY IN THE UNITED STATES IOg tbl.2 (I992).

98 See id. at I I6-30.

99 See, e.g., I3 ANN. REP. OF THE BUREAU OF STAT. OF LABOR AND INDS. OF N.J. FOR THE YEAR ENDING OCT. 3I, I890, at 367 (Trenton, W.S. Sharp Printing Co. I89I) ("[T] of human life is much greater in the peaceful pursuits of industry than in war; and if it were possible to enumerate them, it would be found far greater than during the four years of destruction in the late civil war."). 
There is, of course, nothing surprising about the observation that industrialization generated heightened accident rates. Standard accounts of the history of legal change during the late nineteenth century take as their starting point the cascade of injuries from railroads, machines, mechanized workplaces, streetcars, and the many other dangerous incidents of modern economic life. ${ }^{100}$ Yet it is worth exploring the question in more detail because some historians have challenged the idea that industrialization and urbanization were accompanied by growth in accident rates. Economic historian Paul Uselding, for example, uses data on the mortality rates of workers in various occupations to conclude that industrial manufacturing work was no more dangerous than nonindustrial occupations. ${ }^{101}$ Similarly, historian Randolph Bergstrom concludes from coroners' data on accidental death rates that, contrary to conventional wisdom, accident rates were generally constant over time in the late nineteenth and early twentieth centuries. ${ }^{102}$

The available statistics, however, furnish good reason to doubt the accuracy of Uselding's and Bergstrom's conclusions. It is notoriously difficult to measure accidental injury and death rates during the nineteenth century. Statistics gathered in the middle part of the century by state railroad commissions, and subsequently by state bureaus of labor statistics, chronically underestimated accident rates because they relied almost entirely on employer self-reporting. ${ }^{103}$ Apparent changes in accident rates in the early statistics often reflected little more than changes in the effectiveness of data gathering. Moreover, the great difficulty in measuring accident rates in the late nineteenth century is that while fatality rates provide the most reliable statistics, improvements in medical care during the period in question make mortality rates an unreliable measure of accident rates generally. The pressures that the Civil War placed on the American medical establishment

\footnotetext{
100 See, e.g., FRIEDMAN, supra note 8 , at 467.

101 See Paul Uselding, In Dispraise of the Muckrakers: United States Occupational Mortality, I890-I I IO, I RES. ECON. HIST. 334, 348-5 I (I976).

102 See BERGSTROM, supra note 58 , at 40-57.

103 In some cases, the underreporting of accidents resulted from primitive record-keeping practices in nineteenth-century firms, especially in smaller, less sophisticated firms. See 17 ANN. REP. N.Y. LABOR STAT., supra note 78 , at 567-68. In other cases, underreporting resulted from employers' incentives to keep state factory inspectors, who could order the installation of expensive safety devices, away from their workplaces. In any event, observers commonly agreed that accidents were vastly underreported. In 1890 , for example, the New York State factory inspector explained:

I do not think that the tables given [of work accidents in the state] contain more than a small fraction of the accidents which happened in New York city. Notwithstanding the fact that it is a misdemeanor punishable by severe penalties for an employer or his responsible agent not to report accidents within forty-eight hours after their occurrence, the information that such accidents have occurred is carefully suppressed from the inspectors, and it is by accident that the facts are oftentimes obtained.
} 
prompted the development of modern organizational structures in hospitals and gave rise to the modern nursing profession. ${ }^{104}$ More importantly still, the 1870 S and 1880 os witnessed the widespread introduction of germ theory and antiseptic surgery into American hospitals, fundamentally transforming the practice of medicine and dramatically improving the survival rates for surgeries such as amputations. ${ }^{105}$ If more and more injuries that would have resulted in death in the $1860 \mathrm{~s}$ were being treated successfully by I 900 , then even relatively constant accidental death rates over the course of the late nineteenth century suggest sharply increased rates of serious accidental injury. ${ }^{106}$

Nonetheless, the statistics that are available indicate that accident rates in Western nations grew sharply in the mid-nineteenth century. In England, the percentage of all deaths resulting from violent causes rose by over $350 \%$ between 1700 and the mid-I 800 s, even though deaths from homicide and execution fell sharply after the late I 700 s. $^{107}$ Similarly, in France, accidental deaths per 100,000 individuals almost doubled, from fifteen in the late 1820 s to twenty-eight by $1860 .{ }^{108}$

Accident rates in the United States are more difficult to determine, but they too appear to have increased dramatically during the midand late nineteenth century. The 1850 census was the first to count deaths from accidents. During the next thirty years, the share of deaths attributable to accident among men aged ten to fifty increased by over $70 \%$, from $7 \%$ to $12 \% .109$ Growth in the share of deaths at-

104 See ADAMS, supra note 89, at I 76-84; CUNNINGHAM, supra note 88, at 267-73; 4 NEVINS, supra note 90 , at 3 II-I 4 .

105 See Charles E. Rosenberg, The Care of Strangers: THe Rise of AMERICA's HosPITAL SYSTEM I $22-65$ (I 987 ); see also LESTER S. KING, TRANSFORMATIONS IN AMERICAN MEDICINE: FROM BENJAMIN RUSH TO WILLIAM OSLER I80-8I (I99I).

106 Uselding, in concluding that nonindustrial and industrial occupations were equally hazardous, relies on the dubious assumption that the mortality rates of men within a particular occupation reflected the dangerousness of that occupation. See Uselding, supra note IoI, at 349 . Uselding's comparison of industrial and nonindustrial occupational death rates does not account for the fact that advances in medical care were likely to be more readily available to industrial workers and workers in urban areas than to nonindustrial or agricultural workers. See id. at 34I-48. Similarly, although Bergstrom purports to account for improvements in medical care over time, see BERGSTROM, supra note 58 , at 53 , the evidence he advances for his conclusion that "accident rates were not rising" between 1870 and 1910 appears to rest largely on fixed ratios of accidental injuries to accidental deaths, see, e.g., id. at $4 \mathrm{I}$ tbl. 3 (presenting relatively constant rates of accidental death per capita over time).

$107 \rightarrow$ Cornelius Walford, On the Number of Deaths from Accident, Negligence, Violence, and Misadventure in the United Kingdom and Some Other Countries, 44 J. STAT. SOC'Y LONDON 444, $450,452,485$ (I88I). The actual growth is likely to be considerably higher than $350 \%$ because the figures for 1700 were collected for London only, whereas nineteenth-century figures were collected from a wider range of locales. It is likely that in I 700 (as in the nineteenth century) accidental death rates were higher in London than in the agricultural countryside. $\rightarrow i d$. at 454 .

$\rightarrow$ Id. at 476 .

109 I compiled these figures from the published census reports from 1850 to 1880 . See J.D.B. DE Bow, Superintendent, U.S. Census, Mortality Statistics of the Seventh Census of 
tributable to accidents was especially pronounced in the North. In southern states such as Alabama, Louisiana, and South Carolina, accidents accounted for roughly the same percentage of deaths among men aged ten to fifty in 1870 as in 1850 , ranging from $5 \%$ to $9 \% .110$ In northern states such as Massachusetts and Pennsylvania, by contrast, accidents accounted respectively for $6 \%$ and $7 \%$ of the deaths of men aged ten to fifty in 1850 , and $12 \%$ and $15 \%$ of such deaths in 1870.111 And among particular classes of accidents, the increased share of deaths attributable to accidents was even greater. In 1860 , railroad accidents accounted for only $0.6 \%$ of deaths among males aged ten to fifty; by 1890 , that figure jumped to almost $3 \%$, a fivefold increase. ${ }^{112}$ It was commonly accepted, moreover, that accident rates in the late nineteenth and early twentieth-century United States were considerably higher than in Europe. ${ }^{113}$ And by comparison to late twentiethcentury and early twenty-first-century accident rates, late nineteenthcentury rates of accidental injury and death were staggering. In I9I2, the best study of deaths from accidental injury estimated 82,500 deaths per year; ${ }^{114}$ today, the population of the United States has tripled, but the number of accidental deaths has remained virtually constant. ${ }^{115}$

Workplace injuries were far and away the leading category of accidental injury and death in turn-of-the-century America, representing

THE UNITED STATES, I850, at I 7-20 (Washington, D.C., A.O.P. Nicholson I855); SEC'y OF THE INTERIOR, STATISTICS OF THE UNITED STATES, (INCLUDING MORTALITY, PROPERTY, \&C.,) IN I860, at 52-55 (Washington, D.C., Gov't Printing Office I866); 2 VITAL STATISTICS OF THE United States, Embracing the Tables of Deaths, Births, SeX, and Age, Ninth Census 20-22 (Washington, D.C., Gov't Printing Office I872) [hereinafter VITAL STATISTICS]; JOHN S. BILlings, RePORT ON THE MORTALITY aNd Vital STATISTICS OF THE UNITED STATES AS RETURNED AT THE TENTH Census (JUNE I, I880), pt. I, at 44-53 (Washington, D.C., Gov't Printing Office I 885 ).

110 DE Bow, supra note Io9, at 50-53 (Alabama); id. at 99-I I I (Louisiana); id. at 250-55 (South Carolina); 2 VITAL STATISTICS, supra note I09, at 22-25 (Alabama); id. at 84-87 (Louisiana); id. at 164-67 (South Carolina).

111 I compiled these figures from the published census reports from 1850 to 1870 . Changes in the 1880 census report make it difficult to calculate state-by-state death figures. See DE BOw, supra note I09, at 132-37 (Massachusetts); id. at 235-39 (Pennsylvania); 2 VITAL STATISTICS, supra note 109, at 96-99 (Massachusetts); id. at 156-59 (Pennsylvania).

112 I compiled these figures from the published census reports from I860 to I890. See JOHN S. BILLINGS, REPORT ON VITAL AND SOCIAL STATISTICS IN THE UNITED STATES AT THE ELEVENTh Census: 1890, PART I. - ANALYSIS AND RATe TABles 740-45 (Washington, D.C., Gov't Printing Office I896); SEC'Y OF THE INTERIOR, supra note IO9, at 53-55.

113 One early twentieth-century study of railroad fatalities found that in the years from I89 I to 1903, fatalities were four times more common per mile of train line in the United States than in England. $\rightarrow$ Doten, supra note ${ }_{15}$, at ${ }_{155} \mathrm{I}_{67}$; see also ALDRICH, supra note ${ }_{13}$, at 17 (stating that in 1889 the fatality rate for railroad employees in the United States was nearly fifty percent higher than in Great Britain).

114 Hoffman, supra note II, at I 7 .

115 See NATIONAL Vital STATISTICS REPORTS, supra note $\mathrm{i} 7$, at 26 tbl.8 (stating that there were 97,835 deaths from accidents and adverse effects in the United States in I998). 
close to one third of all accidental deaths and one half of all accidental injuries. $^{116}$ Indeed, accidents were the leading cause of death among workers in hazardous industries such as railroads and mining. ${ }^{117}$ In I890, railroad workers' death rates were 3 I4 per hundred thousand workers per year. Coal miners' fatality rates were comparable, ranging from 215 deaths per hundred thousand workers per year in bituminous coal mines to 300 deaths per hundred thousand workers per year in anthracite coal mines. ${ }^{118}$ Certain subsets of workers in these dangerous industries had even higher rates of accidental death; trainmen, whose jobs required that they operate the coupling devices between cars, and brakemen, who operated the train's handbrakes, died in work-related accidents at rates of 900 and II4I deaths per hundred thousand workers per year, respectively. ${ }^{119}$ Moreover, in I890 railroad and mine workers alone represented more than one in twenty American wage-earners. ${ }^{120}$ In short, a significant portion of the nation's labor force was subject to extraordinarily high work-accident rates. ${ }^{121}$

It is clear that nineteenth-century observers believed that the number of accidental injuries was increasing rapidly. Moreover, they were certain that the cause of the perceived increase in injury rates was the increased mechanization of industrial life. ${ }^{122}$ Muckraking journalists of the early twentieth century, of course, voiced this complaint quite

116 See Hoffman, supra note II, at I, I7 (stating that there were two million accidental injuries and deaths per year total and one million accidental injuries and deaths in the workplace per year; 82,500 accidental deaths per year total and 25,000 accidental workplace deaths per year). By comparison, in the I990s, work accidents represented approximately twenty-five percent of all accidents. See Deborah R. Hensler, M. Susan Marquis, Allan F. Abrahamse, Sandra H. Berry, Patricia A. Ebener, Elizabeth G. Lewis, E. Allan lind, Robert J. MacCoun, Willard G. MANNing, JEANNETTE A. Rogowski \& MARY E. VAIANA, COMPENSATION FOR ACCIDENTAL INJURIES IN THE UNITED STATES 23 (I99I) [hereinafter COMPENSATION FOR ACCIDENTAL INJURIES].

117 Other occupations in which accidents were the leading cause of death included rubber factory operatives, boatmen and canalmen, quarrymen, telegraph and telephone linemen and electric lightmen, and brick- and tile-makers and terra cotta workers. See BILLINGS, supra note I I2, at $980-83$.

118 ALDRICH, supra note $\mathrm{I}_{3}$, at $\mathrm{I}_{5}, 284-85,300-\mathrm{OI}$.

119 Id. at $\mathrm{I} 5$.

120 See id.

121 See id. In I900, approximately one percent of the population fell victim to a work accident resulting in death or disability lasting more than four weeks. By contrast, in 1990, less than one percent of the population suffered any injury - workplace related or otherwise - requiring medical attention or causing a restriction in activities. See DON DEWEES, DAVID DUfF \& MICHAEL TREBILCOCK, EXPLORING THE DOMAIN OF ACCIDENT LAW: TAKING THE FACTS SERIOUSLY 3 (1996) (stating that in 1985, 2.3 million Americans suffered serious injuries and 143,000 died as a result of injuries sustained in accidents). I calculated these percentages by reference to the population statistics in HISTORICAL STATISTICS OF THE STATES OF THE UNITED STATES: TWO CENTURIES OF THE CENSUS, I 790-1990, at I03-04 (Donald B. Dodd ed., I993).

122 Cf., e.g., P.W.J. BARTRIP \& S.B. BURMAN, THE WOUNDED SOldiers OF INDUSTRY: INDUSTRIAL COMPENSATION POLICY, I833-I897, at I4 (I983) (describing perceptions of work accidents in England). 
vigorously. "The radical revolution in industrial methods," contended a typical article in the New York magazine The Independent, "has involved a vast increase of danger to the laborers."123 Accidental death and injury, wrote another journalist, were "the inevitable concomitants of high-speed machine production." Yet the rate of accidents had increased to such an extent, he argued, as to be "unjust, wasteful of money and human life, and generally intolerable." 124 All in all, the muckraking press agreed that the accident problem had become "one of the most extraordinary conflicts in our industrial history,"125 representing nothing short of "a state of continual war between capital and labor." 126

More sober observers agreed that the rate of accidents was growing. In the United States, census takers continually added new categories to their listing of deaths by accident and injury. The 1850 census measured the number of accidental deaths from burns, drownings, scaldings, and other "accidents." 127 The I 860 census added new categories, including one for "accidents, railroad," 128 and the I 870 census added "[m]ining accidents," "[i]njuries by machinery," and accidents from "[f]alling bodies." 129 In France, the chief of the General Statistical Department concluded in 1865 that the number of accidental deaths was increasing throughout the Western world at a rate greater than the rate of population growth. ${ }^{130}$ And in England, students of accident statistics in the $I 880$ s believed that the ratio of deaths from accidental injury to deaths from all causes had been increasing since the beginning of the century. ${ }^{131}$

Many also agreed that industrialization caused the increases in accident rates. The first statistical studies of accidents in England in the I 850 s centered on the problem of railroad accidents, to which an "unusual degree of public attention" had "recently [been] directed." 132

123 Chauncey B. Brewster, Industrial War or Peace, INDEP., June 29 , I9I I, at 1417.

124 Robert W. Bruère, The Welfare War, HARPER'S MAG., Oct. I9I I, at 674.

125 Id.

126 Brewster, supra note I 23 , at 1417.

127 See DE BOW, supra note 109 , at $\mathrm{I} 7-20$. Individual state reports in the 1850 census occasionally listed additional categories such as "explo[sion] ... steam" (Louisiana), "accident . . . railroad" (Louisiana and Massachusetts), and "accident ... machinery" (Massachusetts and New York). Id. at $99-1$ I I , I 32-37, I83-87.

128 See SEC'Y OF THE INTERIOR, supra note IO9, at 4, 52-55.

129 Francis A. WALKER, DEP'T OF THE INTERIOR, VitAL STATISTICS OF THE UNITED STATES xix, I8-2 I (Washington, D.C., Gov't Printing Office I872). "Falling bodies" appears to have been a reference to falling objects (linked, no doubt, to the construction of increasingly tall buildings), not falling cadavers.

$\rightarrow$ Walford, supra note 107 , at 476 .

$\rightarrow$ Id. at 464 .

$\rightarrow$ F.G.P. Neison, Analytical View of Railway Accidents, I6 J. STAT. SOC'Y LONDON 289, 289 (1853). See generc $\rightarrow$ F.G.P. Neison, Analytical View of Railway Accidents, i7 J. STAT. Soc'Y LONDON 2 I9 (I854). 
Subsequent nineteenth-century and early twentieth-century studies of accidents continued to focus on railroads and also expanded to factories and other mechanized workplaces. ${ }^{133}$ "[T]he general feeling," explained a U.S. Department of Labor investigator, "is that the introduction of high power and complicated machinery has resulted in the increase in the number and severity of accidents."134 One English observer even posited that the accidental death rate bore an arithmetical proportionality "to the quantity of mechanical force in use."135 It comes as no surprise, then, that the first accident insurance company, founded in 1845 in London, dedicated itself entirely to insuring railway passengers against accidents; ${ }^{136}$ by 1864 , the Travelers' Insurance Company became the first company to take up the same line of business in the United States. ${ }^{137}$

Whether or not there was an increase in the rate of accidents during the late nineteenth century (and it appears that there was), the industrial revolution devised myriad new and unfamiliar mechanisms for inflicting harm on the human body. If age-old sources of injury, illness, and premature death had been more or less integrated into the fabric of everyday life, new industrial causes of accident and death stood out in bold relief against the background of traditional and familiar sources of human suffering. "[T]he various and continually multiplying uses of steam and of electricity," observed one accident insurance expert in I89I, "are surrounding us with a thousand dangers which not only were unknown to our fathers, but which were strange to the boyhood and to the early manhood of those who have hardly reached middle age."138 Charles Francis Adams, a railroad commissioner in Massachusetts and later commissioner of the Interstate Commerce Commission and head of the Union Pacific Railroad, remarked in 1879 that "there are few things of which either nature or man is, as a rule, more lavish than human life; - provided always that the methods used in extinguishing it are customary and not unduly obtrusive on the sight and nerves." 139 By contrast, those features of industrial life that developed novel methods of human destruction were "anxiously investigated by ingenious men."140 Adams sensibly pointed out that given the extraordinary technological feat represented

133 See, $1 \rightarrow$ Doten, supra note $\mathrm{I}_{5}$, at $\rightarrow \rightarrow$ Katharine Pearson Woods, Accidents in Factories and Elsewhere, 4 PUBliCATIONS AM. STAT. AsS'N 303, 303 (I895).

134 WILlOUGHBY, supra note 82 , at 7 .

$\rightarrow$ Walford, supra note 107 , at 464 .

136 James R. Pitcher, Accidents and Accident Insurance, I 2 FORUM I 3 I, I 33 (I89I).

137 See id.

138 Id. at 136.

139 Charles Francis Adams, JR., Notes on Railroad Accidents i (New York, G.P. Putnam's Sons I879).

140 Id. at 2. 
by the development of the railroad, the number of railroad accidents at the close of the I870s - even if appalling by some standards - was cause for celebration. Who, after all, could have thought merely a half century before that "a body weighing in the neighborhood of two hundred tons, moving over the face of the earth at a speed of sixty feet a second and held to its course only by two slender lines of iron rails" could ever have been made as safe as it was? ${ }^{141}$ But while ancient and familiar sources of tragedy appeared to be caused by some combination of natural forces, acts of God, and fate, railroad accidents seemed to have human causes that were direct and immediate. As Carroll Wright of the Massachusetts Bureau of Labor Statistics observed in I883, disability and death arising out of age-old sources could be chalked up to mere chance. In railroad accidents, by contrast, Wright claimed that most Americans believed that "[n]o man dies without a cause, though the cause and the causer may remain alike unknown." ${ }^{142}$

\section{B. Amputee Workingmen, Destitute Widows, and the Crisis of Free Labor}

I. The Multiple Ideals of Free Labor. - Although European examples played an important role in influencing the direction of American accident law reform, Americans interpreted the industrial accident problem in terms of an ideological framework unique to the United States.

By the 1840 and 1850 s, increasing numbers of Americans in the North viewed free markets in labor as the centerpiece of economic and political freedoms. To be sure, some Americans saw in the wage labor relation what Southern slaveholder and ideologue George Fitzhugh called "a more perfect compulsion" of the worker. ${ }^{143}$ And not all of these critics of free labor were Southerners; a number of labor reformers in the antebellum North argued that labor markets reduced the wage worker to the dependent condition of "wage slavery."144 Still, William Lloyd Garrison captured the increasingly dominant strain of thinking about free labor when he observed that the wage laborer, unlike the slave, was a "free agent." The wage laborer, after all, "con-

141 Id. at 269; see also I I ANN. REP. N.J. LABOR \& INDS. STAT., supra note 84, at 3 ("But what is still more remarkable is the comparatively small number of accidents to travelers, and that this danger has been constantly diminishing.").

142 I4 ANN. REP. MASS. LABOR STAT., supra note 80, at 68.

143 George Fitzhugh, Cannibals All! OR, Slaves Without Masters 32 (C. Vann Woodward ed., Harvard Univ. Press I960) (1857).

144 Amy Dru Stanley, From Bondage to Contract: WAGE LABOR, MARRIAGe, AND THE

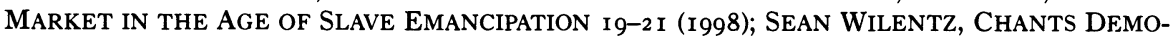
CRATIC: NEW YORK CITY \& THE RISE OF THE AMERICAN WORKING ClASS, I 788-I850, at 33132 (I984). 
tract[ed] for his own wages" and "own[ed] himself." He was "the "lord of his presence' ... though he may be 'lord of no land beside." 145

The Civil War cemented the ideal of free labor as the core of the American national ideology. The Thirteenth Amendment - ratified in I 865 - prohibited slavery and involuntary servitude except as a punishment for crime. Many Americans, of course, flouted the commitment to free labor announced in the Thirteenth Amendment. In the South especially, peonage, sharecropping, vagrancy statutes, and convict labor recreated many of the conditions of slavery. Nonetheless, the free labor ideal stood as the central legacy of the great national conflict; as a political ideal, it was virtually unchallengeable in the decades after the close of the Civil War. ${ }^{146}$

The centrality of the free labor ideal, however, obscured the fact that Americans understood the core value of free labor in a number of quite different ways. ${ }^{147}$ Such conceptions of free labor overlapped in important respects, and many Americans subscribed to more than one of them. But the competing perspectives on the meaning of free labor held very different implications for the challenges of adapting the free labor ideal to an industrializing economy. According to some, for example, the chief virtue of free labor was its efficiency; on this view, free labor served as a better inducement to productive work than mechanisms of coerced labor. ${ }^{148}$ For others, the legitimacy of free labor rested on its capacity to provide a family wage that allowed workingmen to support wives and children. ${ }^{149}$ For our purposes, however, two competing conceptions of free labor emerged in the years following the Civil War: the classical liberal ideal of autonomy and the labor movement's ideal of substantive independence. ${ }^{150}$

(a) The Liberal Ideal of Autonomy. - For some, the central value of free labor was its commitment to liberalism and individual autonomy. ${ }^{151}$ Atlantic Monthly editor William Dean Howells, for example,

145 STANLEY, supra note $\mathrm{I} 44$, at $2 \mathrm{I}$.

146 The two leading accounts of this history are ERIC FONER, FREE SOIL, FrEE LABOR, FREE MEN: THE IDEOLOGY OF THE REPUBLICAN PARTY BEFORE THE CiVIL WAR 6, 74-I IO (I970); and ERIC FONER, RECONSTRUCTION: AMERICA'S UNFINISHED REVOLUTION, I863-I 877 (I988).

147 See Eric Foner, Nothing But FreEdom: EMANCIPATION AND ITS LEGACY (I983); William E. Forbath, The Ambiguities of Free Labor: Labor and the Law in the Gilded Age, I985 WIS. L. REV. 767 .

148 See Jonathan A. Glickstein, "Poverty is Not Slavery": American Abolitionists and the Competitive Labor Market, in ANTISLAVERY RECONSIDERED I98 (Lewis Perry \& Michael Fellman eds., I979).

149 See STANLEY, supra note I44, at $\mathrm{I}_{38-40}$; see also NANCY F. COTT, THE BONDS OF WOMANHOOD: "WOMAN'S SPHERE" IN NEW ENGLAND, I $780-1835$, at 2 I (I977).

150 The former conception of free labor was held quite strongly by supporters of state accident insurance systems; private employer accident compensation schemes embodied the latter.

151 See DAVId MONTGOMERY, BEYOND EQUALITY: LABOR AND THE RADICAL REPUBLICANS I 862-I872, at 379-80 (I967); Forbath, supra note I47, at 786-94. For a discussion of the early nine- 
argued that "order" and "government" could be rescued from the heightening "chaos" and "anarchy" of the industrial economy only by the adoption of a liberal approach to American self-government. Howells contended that individual "moral self-control," rather than state action, held the key to liberty and order in these industrial times. ${ }^{152}$ Similarly, leading liberals such as E.L. Godkin of The Nation saw in the Union's triumph in the Civil War a vindication of the principles of classical liberalism. Free labor, for Godkin, meant the promotion of consensual relationships among autonomous private actors over the compulsory or coercive relations that had characterized the slave South.

(b) The Labor Ideal of Independence. - Leaders in the American labor movement, by contrast, saw in the free labor ideal a substantive commitment to independence rather than autonomy. Though similar in some respects to the liberal ideal of autonomy, independence stood for a different principle. Those who valued autonomy supported the maintenance of procedures for unconstrained freedom of choice, without regard to the substance of the choices that individuals made. Free markets in labor thus formed a critically important part of the liberal conception of procedural justice, for labor markets institutionalized the consensual formation of labor relations. ${ }^{153}$ The labor movement, however, valued not procedures for the realization of autonomous choice, but rather substantive outcomes that guaranteed citizens' independence. ${ }^{154}$ In particular, the labor movement drew on the long tradition of "republicanism" in political thought that prized the public virtues of an independent citizenry over the privatized good of autonomous individuals. ${ }^{155}$

From the workingman's perspective, the spread of wage labor markets posed a potential threat to free labor ideals of independence.

teenth-century origins of the relationship between free labor values and liberal political thought, see GORDON S. WOOD, THE RADICALISM OF THE AMERICAN REVOLUTION 276-86 (I 993 ).

152 W.D. Howells, Editorial, 29 ATLANTIC MONTHLY I24, I 26 (I872); see also MONTGOMERY, supra note $15 \mathrm{I}$, at $379-80$.

153 For a discussion of liberalism as a "procedural" theory of politics, see MichaEL SANDEL, Democracy AND ITS Discontents (1996); and Michael J. SANDEl, Liberalism AND THE LIMITS OF JUSTICE I 20-2 I (I982) [hereinafter SANDEL, LIBERALISM].

154 See LEON FINK, WORKINGMEN's DEMOCRACY: THE KNIGHTS OF LABOR AND AMERICAN POLITICS 3-I5 (I983); Forbath, supra note I47, at 800-I I; DAVID MONTGOMERY, CITIZEN WORKER: THE EXPERIENCE OF WORKERS IN THE UNITED STATES WITH DEMOCRACY AND THE FREE Market DURING the Nineteenth Century 43-5 I (I993); David MONTgomery, The Fall OF THE HOUSE OF LABOR 2 2-44 (I 987 ).

155 See generally JOYCE APPLEBY, LIBERALISM AND REPUBLICANISM IN THE HISTORICAL IMAGINATION (I992); BERNARD BAILYN, THE IDEOLOGICAL ORIGINS OF THE AMERICAN REVOLUtion (I967); J.G.A. Pocock, The Machiavellian Moment: FloRentine Political Thought and the Atlantic Republican Tradition (I975); Gordon S. WoOd, The CreaTION OF THE AMERICAN REPUBLIC, 1776 -I 787 (I969). 
Wage labor, after all, resembled slavery in that it rested on the sale of human labor power. To be sure, the free labor sale of labor power was only for a term, not for life. But as labor leaders observed, an ostensibly free laborer forced by circumstances into a lifetime of back-to-back employment contracts was, in effect, required to sell his labor power for life. ${ }^{156}$ Confidence in the political virtues of free markets in labor thus rested in large part on the idea that wage laborers would, in time, become independent proprietors. In Lincoln's famous words, "[i]f any continue through life in the condition of the hired laborer, it is not the fault of the system." Instead, Lincoln contended, prolonged wage laborer status manifested "either a dependent nature which prefers it, or improvidence, folly, or singular misfortune." 157

2. The Dilemmas of Free Labor. - By the late 1870 os and $1880 \mathrm{os}$, each of these conceptions of free labor faced new challenges. Increasing interdependence and inequalities of wealth, for example, threatened liberals' aspirations toward an ideal of autonomy. In an urbanizing and industrializing world, it was not entirely clear that the boundaries of individual autonomy could be meaningfully established. Moreover, the disparate resources of the rich and the poor raised the possibility that ostensibly consensual interactions might become relations of coercion.

Similarly, the spread of wage labor undermined the prized independence of the American workingman. Already in 1870, over two thirds of all gainfully employed Americans were hirelings rather than independent proprietors or master craftsmen. ${ }^{158}$ Subsequent years saw further increases in the proportion of workingmen who were wageearners. By 1873, the Massachusetts Bureau of Statistics of Labor announced that wage labor had become "a system more widely diffused than any form of religion, or of government, or indeed, of any language." 159 And in the ensuing decades, the work of state labor statistics departments came to focus virtually exclusively on the problems of wage-earners. "It is characteristic of the condition of the free laborer today," wrote one accident insurance expert at the turn of the century, "that he possesses no capital."160 Indeed, "his only means of livelihood is the sale of his labor power." 161 The Lincolnian dream of the wage laborer's rise to independence, it seemed, was increasingly out of step

\footnotetext{
156 See MONTGOMERY, supra note I5 I, at 379-80; STANLEY, supra note I44, at 93.

1573 The Collected Works OF ABrahaM LinCOLN 479 (Roy P. Basler ed., I953); MONTGOMERY, supra note I5 I, at 3 I.

158 See MONTGOMERY, supra note I5 I, at 29-30.

159 STANLEY, supra note I44, at 62 (citing 4 ANN. REP. MASS. BUREAU OF STAT. OF LABOR 440 (Boston, Wright \& Potter I883)).

160 Rubinow, supra note 87 , at 362 .

161 Id.
} 
with the social structure of a free labor economy in which wageearning was not a temporary phase but a permanent condition.

Moreover, many American workingmen understood their independence as workers to be closely linked to their capacity to support and maintain their wives and children in a secure domestic life separate and apart from the market. Yet even as wage labor was undermining the independence of workers in the labor market, social conditions began to undermine the free labor system's capacity to preserve an independent domestic sphere. Many Americans thus began to worry that low wages and cyclical unemployment would force increasing numbers of young people to avoid marriage altogether. ${ }^{162}$ And in the final years of the nineteenth century, widespread public concern about child labor and prostitution indicated that the free labor system was failing in its aim of shielding women and children from the exigencies of the marketplace. ${ }^{163}$

3. Industrial Accidents and the Dilemmas of Free Labor. - By the turn of the century, industrial accidents stood at the center of American anxieties about the viability of free labor ideals in an industrial economy. Indeed, notwithstanding concern over declining autonomy, the spread of wage labor, cyclical unemployment, declining marriage rates, and an apparent rise in prostitution, industrial accidents increasingly provided the most vivid manifestation of the crises of free labor ideals.

In part, growing concern for the accident problem resulted from the startling imagery of the industrial accident victim. Unlike other industrial problems, industrial accidents left visible and deeply disturbing marks on their victims. As Lewis Hine documented in his photographic essays on injured workingmen and their families, the startling violence of encounters between flesh and machine was readily apparent in the form of missing limbs and scarred bodies. ${ }^{164}$ As a result, by the first decade of the twentieth century the industrial injury became a symbol for a wide array of industrial problems.

The importance of industrial accidents was more than symbolic, however. In I893 Carroll Wright wrote that of all the "subject[s] within the whole range of social economics," the single most important problem was "the economic insecurity attending the [nation's] great

162 See STANLEY, supra note $\mathrm{I} 44$, at $\mathrm{I} 38-74$.

163 See id. at 2 I 8-63. On anxieties about women in commerce in the late nineteenth century, see also Barbara Meil Hobson, Uneasy Virtue: The Politics of Prostitution and The AMERICAN REFORM TRADITION (I987); RUTH ROSEN, THE LOST SISTERHOOD: PROSTITUTION IN AMERICA, I900-I9I8 (I982).

164 For photographs, see CRYSTAL EASTMAN, WORK-ACCIDENTS AND THE LAW I44, I49, I53, I56 (I9IO). 
industries."165 And of all the sources of such economic insecurity, social insurance student William Willoughby argued that accidents loomed largest. Unlike workingmen in Europe, Willoughby claimed in the mid-I89os, American workers rarely looked to outside assistance for infirmities of old age or sickness. But accidents were difficult to anticipate. And even for those American workers who sought to make provisions for the possibility of accidental injury or death, the typical over-optimism of individuals frequently left injured workingmen and their families less than fully prepared. Thus according to Willoughby it was in the "field of accidents alone" that free labor ideals were severely threatened. ${ }^{166}$ And by the first decade of the twentieth century, such organizations as the American Association for Labor Legislation listed industrial accidents as the first and most important problem facing working-class families. ${ }^{167}$

Not everyone thought that accidents posed the most significant problem for American wage-earners. Looking back from the perspective of the I930s on his career as a social insurance expert at the opening of the century, I.M. Rubinow named accidents the first of "the Four Horsemen that ride roughshod over lives and fortunes of millions of wage workers": accident, illness, old age, and unemployment. ${ }^{168}$ Yet in I9I3, Rubinow had argued that accidents were "not [] the most serious of the economic dangers confronting the wage earners," and observed that "historically various forms of sick-insurance and old age

165 Carroll D. Wright, Letter of Transmittal, in FOURTH SPECIAL REPORT OF THE COMMISSIONER OF LABOR: COMPULSORY INSURANCE IN GERMANY INCLUDING AN APPENDIX RELATING TO COMPULSORY INSURANCE IN OTHER COUNTRIES IN EUROPE 9, 9 (Washington, D.C., Gov't Printing Office, I895) (internal quotation marks omitted).

166 WILLOUGHBY, supra note 82, at 282-83. Willoughby explained:

In regard to the question of the provision of old-age pensions, or a national system of sick insurance for the benefit of the laboring classes, it can possibly be alleged, with considerable show of reason, that conditions in the United States are so different from what they are in Europe, that the action of the latter furnishes but an indifferent guide as to what should be done here. The same, however, cannot be claimed in the case of accidents to labor. Here, on the contrary, the necessities for measures of reform are even more pressing than in Europe. Accidents are, if anything, more frequent, and the demand that the workingmen who are injured should be indemnified by their employers is equally imperative.

Id. at 327-28; see also Cummings, supra note 78, at 560 (reviewing WilloughBY, supra note 82, and focusing on the special problem of work accidents).

167 See, e.g., Henry R. Seager, Outline of a Program of Social Legislation with Special Reference to Wage-Earners, in LABOR AND OTHER ECONOMIC ESSAYS I3 I (I93I) (listing "industrial accidents" as the first of the "principal contingencies which threaten standards of living"); Henry R. Seager, Outline of a Program of Social Reform, in id. at 79-80 (arguing in an essay originally published in 1907 that protecting "those who have been reduced to poverty because of some accident or misfortune" presents the chief challenge for social reform legislation).

168 I.M. RUBINOW, THE QUEST FOR SECURITY 20-2 I (I934). 
relief preceded accident insurance."169 Similarly, Columbia University economist Henry Seager had contended that illness was "[m]uch more serious than accidents in its effect on standards of living." 170

Even Rubinow and Seager, however, conceded that the industrial accident problem most captured the attention of Americans. ${ }^{171}$ In part, this preoccupation arose out of the fact that accidents - especially work accidents - posed particularly acute problems for working-class families. Industrial accidents disproportionately affected wage-earning men supporting dependent wives and children. In I890, accidents accounted for more than five times as many deaths among men aged fifteen to forty-five as among women of the same age. ${ }^{172}$ Similarly, an 1899 study found that of 1847 persons injured in New York work accidents, only 85 were women. ${ }^{173}$ New immigrant groups from Southern and Eastern Europe were especially hard hit; as early as I890, Hungarians, Bohemians, and Italians were three of the four nationalities with the highest accidental death rates. ${ }^{174}$ And among working-age men in important industrial occupations such as railroad work, mining, logging and timber work, and bricklaying and masonry, workplace accidents were the leading cause of death and incapacity; ${ }^{175}$ according to one 1890 study of the mining trade, deaths from work accidents accounted for sixty percent of all workingmen incapacitated from pursuing the trade. ${ }^{176}$

Moreover, by comparison to other Western nations, the United States seemed especially laggard in its response to the industrial accident problem. "It would be difficult to think of another field of social

169 I.M. Rubinow, Social InSURANCE With SPECIAL REFERENCE to AMERICAN CondiTIONS 49 (I9I3).

170 Henry Rogers Seager, Social InSurance: A Program OF SOCIAL Reform i 7 (1910).

171 See RUBINOW, supra note I69, at 49; SEAGER, supra note I70, at 24-25 (listing industrial accidents as first among "the causes of human misery").

172 See BILliNGS, supra note I09, at 52, 53.

173 I 7 ANN. REP. N.Y. LABOR STAT., supra note 78, at 573.

174 See BillingS, supra note I09, at 455. Scandinavians were the fourth leading group in death rates by nationality.

175 See supra p. 7 I 9 . In 1900 the mortality rate ranged from 590 per 100,000 for men between fifteen and twenty-four years of age, to 820 per 100,000 for men between twenty-five and thirtyfour years of age, to 1070 per 100,000 for men between thirty-five and forty-four years of age. See i BUREAU OF THE CENSUS, U.S. DEP'T OF COMMERCE, HistoriCAl STATISTICS OF THE UNITED States, Colonial Times to i970, at 6i (I975) [hereinafter Historical Statistics OF THE UNITED STATES]. Among railroad workers and miners, the mortality rate from work accidents alone was over 300 deaths per 100,000 workers, making work accidents the leading cause of death among these classes of workers. In addition, state surveys of the causes of incapacity among workingmen identified accidental deaths as the leading cause of incapacitation among many classes of industrial workers. See I4 ANN. REP. N.J. BUREAU OF STAT. OF LABOR \& INDUS. 2 I4 tbl.7 (I89I).

$176 \mathrm{See}$ I3 ANN. REP. N.J. BUREAU OF STAT. OF LABOR \& INDUS. 407 (I89I). 
or legal reform in which the United States is so far behind other nations," announced the New York Bureau of Labor Statistics in I900. ${ }^{177}$

Finally, unlike sickness and old age, the work accident seemed to raise questions about the relationship between the well-being of the laboring classes and the conditions of production in an industrializing age. Sickness and old age, of course, had been constant companions of the human experience for millennia. And although many of the health problems of the late nineteenth and early twentieth centuries could be traced to unsanitary or toxic working conditions, the connections were remote and attenuated. ${ }^{178}$ The work accident, by contrast, placed the status of the modern factory worker, railroad hand, or miner in bold relief and compelled victim and observer alike to ask hard questions about the relationships among capital, labor, and the public.

Accordingly, many turn-of-the-century students of industrial conditions believed that industrial accidents posed greater difficulties for working-class families in the United States than virtually any other social problem. But just as there were differing interpretations of the core meaning of the free labor ideal, so too were there differing interpretations of the precise nature of the industrial accident problem.

(a) Accidents and the Liberal Ideal of Autonomy. - Personal injury and death from accidents threatened liberal aspirations to create a state and a legal system based on the organizing principle of individual autonomy. Every accident, after all, provided clear evidence of the social reality that individuals were heavily interdependent. As accident rates increased, the ideal of autonomy seemed for many Americans less and less relevant to contemporary social conditions. ${ }^{179}$ Moreover, the accident epidemic's disproportionate impact on the laboring classes appeared to implicate the growing economic inequality of the late nineteenth century. ${ }^{180}$

(b) Accidents and the Iniquities of Competitive Wage Labor Capitalism. - From the perspective of the labor movement, the industrial slaughter of workplace accidents became in the I 880 s and I 890 s one of the primary manifestations of the undermining of workingmen's inde-

177 I 7 ANN. REP. N.Y. LABOR STAT., supra note 78, at I 162.

178 On the development of workplace health science expertise, see CHRISTOPHER C. SELLERS, HAZARDS OF THE JOB: FROM INDUSTRIAL DISEASE TO ENVIRONMENTAL HEALTH SCIENCE (I997).

179 Thus, it was a truism in discussions of the accident problem that industrializing nations were shifting from an age of "individualism" to an age of collectivism.

180 See, e.g., ELEVENTH ANNUAL REPORT OF THE BUREAU OF STATISTICS OF LABOR AND INDUSTRIES OF NEW JERSEY FOR THE YEAR ENDING OCTOBER 3 IST, I 888 (I889) ("It certainly is true that the whole number of fatal accidents on our railroads, to passengers and others, constituted but 7 per cent of the aggregate deaths due to accident or injury in 1880 . This fact, nevertheless, is not stated to condone the annual railroad slaughter, nor does it tell the whole story; for of these railroad casualties, a very large proportion happen to employees, to whom the railroad is a veritable juggernaut."). 
pendence. Across a wide array of labor unions, workers demanded safer workplaces and the expansion of employers' liability. ${ }^{181}$ Indeed, industrial accidents stood as a glaring indictment of the iniquities of the underlying system of competitive wage labor capitalism. ${ }^{182}$ Eugene Debs, for example, viewed the accident problem on the railroads as dangerously undermining the manly independence of the American workingman. Workers disabled from their occupations by accidents were rendered dependent on their employers' largesse by the narrow scope of employers' liability. As a result, industrial accidents defeated free labor's promise of independence for workingmen - as, in Debs's words, "manly men." Industrial accidents left railroad workers, again in Debs's phrase, little more than "squaw men," unable to fill the masculine free labor role of family provider. ${ }^{183}$

(c) Accidents and the Crisis of the Family Wage. - The independence that free labor promised workingmen was closely tied to the late nineteenth-century ideal of domesticity and the family wage system. It was the manly free laborer, after all, whose independence guaranteed the preservation of a separate domestic sphere. By the turn of the century, however, the problem of work accidents for the ideals of free labor manhood had come to threaten the household as well. Crystal Eastman's study of work accidents in Pittsburgh noted that the "most appalling feature" of industrial accidents was that they "fell exclusively upon workers, bread-winners." There were no "aged helpless persons" or "idle merry-makers" or "unresponsible children" among the victims of work accidents, she observed. Rather, the people who perished in work accidents were "those upon whom the world leans."184

For Eastman and other like-minded onlookers, the devastating effects of industrial accidents on the domestic life of working class families - the "effect of industrial fatalities upon the home," in Eastman's words $^{185}$ - stood as the most salient aspect of the work accident

181 See, e.g., Edward W. Searing, Employers' Liability Law, I AM. FEDERATIONIST 93, 94-95 (1894) (arguing on behalf of the American Federation of Labor for expanded employers' liability in New York State); INDEPENDENT ORDER OF KNIGHTS OF LABOR, Declaration of Principles, art. VII, in OFFICIAL HANDBOOK: INDEPENDENT ORDER KNIGHTS OF LABOR (I896) (unpaginated) (announcing support for "[ $t$ ]he adoption of measures providing for the health and safety of those engaged in mining, manufacturing and building industries, and for the indemnification of those engaged therein for injuries received through lack of necessary safeguards").

182 See Samuel Gompers, Editorial, Industrial Slaughter and the "Enlightened" Employers, I4 AM. FEDERATIONIST 548, 548 (1907) (arguing that "[t]o expose workmen to unnecessary risks, to save a few dollars at the expense of human lives, limbs, and earning capacity, is positively inhuman, a disgrace to our boasted civilization and progress").

183 Nick Salvatore, Eugene V. DEbS: Citizen AND SOCIALIST 6I (1982).

184 EASTMAN, supra note I64, at I I 9.

185 Id. at 132 ; see also id. at 223 "'To study industrial accidents from the 'home' side has been my business for a year."). 
problem. ${ }^{186}$ Edward T. Devine of the Charity Organization Society of the City of New York, for example, argued that the gravest effects of industrial accidents were their "consequences on the character and permanent social standing of the family." 187 Charitable organizations, he continued, saw "people becoming chronic dependents and begging for charitable assistance, who never would have gotten in that position except for the accident to the wage earner."188 Families that had "heretofore been entirely independent and self-supporting" were thrown by the accidental injury of the male wage-earner into the ranks of the "dispossessed," "pawning their furniture," "using up what little savings-bank account they have had," and "obliged to turn in humiliation and permanent injury to the charitable societies or to relatives and friends." 189

Indeed, the accident epidemic appeared to be creating a new class of industrial invalids. According to the Massachusetts Bureau of Labor Statistics in 1902 , it seemed that " $[t]$ he stress of modern industrial life" was simply "too severe for persons of weak physique." 190 The crisis of "[a]ccidents due to the contingencies of employment" appeared to have enlarged the class of "industrial defectives who, in increasing numbers, are shown in every enumeration of the population." ${ }^{191}$ The Bureau estimated that over two percent of the population fell into the class of "defectives." 192 The majority of crippled and maimed workers, according to the Bureau, was injured working as "[l]aborers," in "[t]ransportation," and in "[m]anufactur[ing]."193

In other states, fears about the effects of industrial occupations on workers' health and safety produced an outpouring of similar studies by state bureaus of labor statistics. In 1887 , for example, Pennsylvania

186 See id. at 223-39. Concern for the effects of industrial accidents on families and on wives is evident in virtually all the state reports issued on the work accident problem around r9ro. See, e.g., 17 ANN. REP. N.Y. LABOR STAT., supra note 78, at 576-78 (detailing persons dependent on earnings of victims of accidents and sources of support of persons injured and their dependents); DON D. LESCOHIER, INDUSTRIAL ACCIDENTS AND EMPLOYERS' LIABILITY IN MINNESOTA, PART II OF THE TWELFTH BIENNIAL REPORT OF THE BUREAU OF LABOR, INDUSTRIES AND COMMERCE OF THE STATE OF MINNESOTA, I 909-I9IO, at I55-57 (I9IO).

187 MINUTES OF EVIDENCE ACCOMPANYING THE FIRST REPORT TO THE LEGISLATURE OF THE STATE OF NEW YORK BY THE COMMISSION APPOINTED UNDER CHAPTER 5 I 8 OF THE LAWS OF I909 TO INQUIRE INTO THE QUESTION OF EMPLOYERS' LIABILITY AND OTHER MATTERS, MAR. I6, I9I0, at 8 (1910) (statement of Edward T. Devine).

188 Id.

189 Id.

190 Mass. Bureau of Statistics of Labor, The Physically Defective Population in Massachusetts in Relation to Industry, 1902 LABOR BULL. COMMONWEALTH OF MASS. I, I.

191 Id.

192 Id. at 2.

193 See id. at 3 tbl. 
launched a study of employer compensation of injured workingmen. ${ }^{194}$ When the Wisconsin Bureau of Labor and Industrial Statistics surveyed the condition of its labor force in 1887 and 1888 , it asked workers a battery of questions about their physical condition: "Are you compelled to exercise more than ordinary care to prevent accidents to self and others?" "What bodily ailments are peculiar to your trade?" "At what age do persons [in your trade] begin to decline physically so as to affect their work and wages?"195 In New Jersey, the Bureau of Statistics of Labor and Industries issued in 1888 a report on railroad accidents and employers' liability that found "a fearful slaughter of employees - one which is increasing at a rate out of all proportion to the expansion of the railroad mileage ... or to the increase in the total number of persons employed." 196 And in 1889 , the New Jersey Bureau began to issue regular annual reports on the "Effect of Occupation on the Health and Duration of the Trade-Life of Workmen,"197 noting that "whether a man loses an arm in war or in a machine shop, he is equally disqualified for work." 198

\section{Alternative Legal Approaches and the Accident Crisis}

The industrial accident problem thus precipitated a crisis for the free labor system that emerged from the Civil War. Yet for different groups of Americans the accident problem meant different things. Liberals in the classical vein understood the accident crisis as posing a threat to autonomy in what appeared to be an increasingly interdependent world. Workingmen, by contrast, viewed the onslaught of work accidents as a manifestation of the underlying injustices of competitive wage labor capitalism and of the dangers capitalism posed for the family wage of independent workingmen and dependent wives and children.

For each of the various ways of understanding the nature of the accident problem, Americans proposed a different solution. Thus, in the decades spanning the turn of the century, Americans devised a number of alternative policy prescriptions designed to address the problems that industrial accidents posed for the free labor system. Many of these alternatives were short-lived. As early as the 1840s, for example, the Pennsylvania mining trade press discussed accident compensation

\footnotetext{
194 Rep. of the Bureau of Indus. Statistics, in I5 ANN. REP. SEC'Y OF INTERNAL AFFAIRS OF COMMONWEALTH OF PA. pt. 3 (1887) ("Industrial Statistics").

195 I887-I 888 WIS. BUREAU OF LABOR \& INDUS. STAT. BIENNIAL REP. I89 tbl.V.

196 I I ANN. REP. N.J. BUREAU OF STAT. OF LABOR \& INDUS. I6 (I888).

197 I 2 ANN. REP. N.J. BUREAU OF STAT. OF LABOR \& INDUS. pt. I (I 889).

198 I 3 ANN. REP. N.J. BUREAU OF STAT. OF LABOR \& INDUS. 367 (I890); see also I MONT. BUREAU OF AGRIC., LABOR \& INDUS. ANN. REP. pt. I, at I2-I 32 (I893) (surveying working conditions of various occupations and detailing disability, death, and funeral benefits available to workers through employers and cooperative self-insurance schemes).
} 
funds financed by a tax on coal sales. ${ }^{199}$ Several decades later, Maryland briefly experimented with a system of compulsory employerfinanced relief funds. ${ }^{200}$ Other proposals developed later, in the first decades of the twentieth century. Private employer compensation plans, for example, became a significant alternative in the first decade of the twentieth century, as did compulsory state accident insurance mechanisms. ${ }^{201}$

But in the decades immediately following the Civil War, two leading alternative approaches to accident law emerged in the United States: the common law of torts and cooperative self-insurance against disability and death. Each represented one of the leading late nineteenth-century strands of free labor thought. And in turn, each embodied one of the leading normative models for how best to solve the problems that beset the industrializing free labor economy.

\section{The Dilemmas of Classical TORT LAW}

"The general principle of our law," Oliver Wendell Holmes explained in his I88I masterpiece The Common Law, "is that loss from accident must lie where it falls." 202 By "accident," Holmes meant injuries occurring "without fault." 203 To be sure, Holmes observed, there were some who advocated shifting liability in such instances of faultless harms. On this view it was said that "[e]very man" had "an absolute right to his person ... free from detriment at the hands of his neighbors." 204 Alternatively, the law could have opted to divide the damages between equally faultless (or equally at-fault) actors. Yet the law did "none of these things," explained Holmes, and instead for reasons of policy left accidental harms to lie where they fell. ${ }^{205}$

Holmes's words have become the classic expression of the late nineteenth-century law of accidents. ${ }^{206}$ Yet there was an important differ-

199 Alexander Trachtenberg, The History of Legislation for the Protection of COAL MINERS IN PENNSYLVANIA, I824-I9I5, at I9 (I942).

200 See Katherine A. HARVEy, The Best-Dressed Miners: Life and LaboR in the MARYLAND COAL REGION, I835-I910, at 4I (I969).

201 For a discussion of private employer-based accident compensation systems, see Witt, supra note 18 , at ch. 4. See also Epstein, supra note 19 , at 797-800 (discussing the adoption of private compensation schemes by English firms). On early developments in social insurance approaches to accidents, see Witt, supra note 18 , ch. 5 .

202 HOLMES, supra note 38 , at 76.

203 Id. (quoting Harvey v. Dunlop, Hill \& Den. 193 (N.Y. I843)) (internal quotation marks omitted).

204 Id. at 68.

205 Id. at 77.

206 The proposition that accidental losses properly lie where they fall was well settled before, and especially after, Holmes's memorable words. See, e.g., Clarke Butler Whittier, Mistake in the Law of Torts, I5 HARV. L. REV. 335, 335 (1902) (observing that "accidents will happen and losses will occur when neither party is at all in fault" and arguing that shifting the costs of such accidents 
ence between Holmes's approach to the problem of accidental harm and the approach of most of the elite of the American bar. For Holmes, the principle that the law favored the active doers of the world over its passive victims seems to have been a part of his Darwinian perspective on human affairs. ${ }^{207}$ Those who fell by the wayside in the competitive struggle for life, in Holmes's view, were simply the losers in an ongoing evolutionary battle from which only the fittest would emerge. Law could do little to aid those who came out on the bottom of such natural and inevitable processes.

For most of the elite of the American bar, however, the proposition that losses from faultless injuries properly lay where they fell represented something very different from Holmes's evolutionary sensibilities. Tort doctrine as elaborated in the late nineteenth century by elite American lawyers and judges represented an attempt to work out in practice the principles of classical liberal thought in an age of enterprise and accident. Lawyers, judges, and legal scholars constructed a grand doctrinal architecture for the law of accidents, centered first and foremost on defining the proper bounds within which individuals were free to act as they chose, unchargeable with liability for harms to others. In this sense, the elaboration of liberal principles embodied in the late nineteenth-century law of torts sought to rationalize and bring order to the increasingly messy world that lay outside the covers of the law reporters, treatises, and bar association reports.

Yet even as classical tort doctrine reached its apogee in the last years of the century, the accumulated wisdom of the elite of the bar and bench was coming under sharp criticism for its inadequate grasp of the late nineteenth-century accident problem. The abstract doctrinal structure of American tort law perched precariously atop a rising mountain of accidents from machinery, railroads, streetcars, and elevators. Personal injury lawyers and their runners, insurance company agents, industrial employers, and injured workers pushed and challenged the justifications offered for the law of torts. And in the end, the liberal project of organizing tort law to embody principles on which individuals could be free to act within a zone of uninfringed autonomy was an impossible task. As critics of tort law would begin to point out by the turn of the century, late nineteenth-century tort law

\footnotetext{
was "useless"); Shaw v. Boston \& Worcester R.R. Corp., 74 Mass. (8 Gray) 45, 67 (I 857) (Shaw, C.J.) (discussing "cases of pure accident, to which all human beings are constantly exposed, for which no person is in fault, and in which all losses and damages occasioned thereby must lie where they first fall").

207 For a discussion of Holmes's social Darwinism, see G. EDWARD WhIte, JUSTICE Oliver WENDELl HOLMES: LAW AND THE INNER SELF I5 I-52, 290-9I, 360 (I993); and Robert W. Gordon, Law as a Vocation: Holmes and the Lawyer's Path, in THE PATH OF THE LAW IN THE TWENTIETH CENTURY (Steven Burton ed., forthcoming 2000).
} 
had no good answer to precisely the problem that Holmes had identified in I88I as the centerpiece of the classical law of torts: the accidental victims of nonnegligent harm.

\section{A. Classical Legal Thought and the Law of Torts}

For the last twenty-five years or so, historians of American law have fundamentally rethought the character of legal thought during the late nineteenth century. Where once Gilded Age lawyers, judges, and legal scholars were depicted as advocates of a laissez-faire social Darwinism that presaged the reactionary Supreme Court of the New Deal, ${ }^{208}$ historians have now redescribed the same lawyers, judges, and scholars as the founders of classical legal thought, a finely wrought set of doctrinal structures derived from classical eighteenth- and nineteenth-century liberalism. ${ }^{209}$ Thus, a new generation of histories of

208 See, e.g., ARNold M. PAul, Conservative Crisis AND the RUle of LaW: Attitudes of BAR AND BENCH, I887-I895, at 229-30 (1960) (describing the conflict between laissez-faire judicial conservatives and progressive reformers).

209 In large part this revisionist project has sought to disentangle Holmes's complex and misleading views from those of the late nineteenth-century bar more generally. Holmes, of course, famously decried what he saw as the social Darwinist conceptions that underlay turn-of-the-century American constitutional law. See Lochner v. New York, I98 U.S. 45, 75 (I905) (Holmes, J., dissenting) ("The I 4 th Amendment does not enact Mr. Herbert Spencer's Social Statics."). Yet it now appears that Holmes himself may have been the only real social Darwinist on the Court, and one of the few among the elite of the bar. For examples of early revisionist approaches, see Robert W. Gordon, Holmes' Common Law as Legal and Social Science, Io HoFSTRA L. REV. 7 I9 (I982) [hereinafter Gordon, Holmes' Common Law]; Robert W. Gordon, Legal Thought and Legal Practice in the Age of American Enterprise, 1870-1920, in PROFESSIONS AND PROFESSIONAL IDEOLOGIES IN AMERICA 70 (Gerald L. Geison ed., I983); Duncan Kennedy, Toward an Historical Understanding of Legal Consciousness: The Case of Classical Legal Thought in America, 18501940, 3 RES. L. \& SOC. 3 (1980); Michael Les Benedict, Laissez-Faire and Liberty: A Re-Evaluation of the Meaning and Origins of Laissez-Faire Constitutionalism, 3 LAW \& HIST. REV. 293 (I985); Charles W. McCurdy, Justice Field and the Jurisprudence of Government-Business Relations: Some Parameters of Laissez-Faire Constitutionalism, I863-I897, 6I J. AM. HIST. 970 (I975); and William E. Nelson, The Impact of the Antislavery Movement upon Styles of Judicial Reasoning in Nineteenth Century America, 87 HARV. L. REV. 5 I3 (1974). More recent accounts building on the earlier work include I BRUCE ACKERMAN, WE THE PEOPLE: FoundATIONS 42-43, IO0-IO4 (I99I); 2 BRUCE ACKerman, We the PEOPLE: TRANSFormations 256-57, 279-8I (I998); Barry Cushman, Rethinking the New Deal Court: The Structure of a Constitutional Revolution (ig98); OWEN M. Fiss, Troubled BeginNings of the

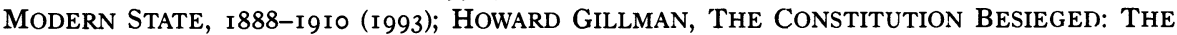
Rise AND DEMISE OF LOCHNER ERA POLICE POWERS JURISPRUdenCE (I993); HoRWITZ, TRANSFORMATION II, supra note 7; Paul D. Carrington, The Constitutional Law Scholarship of Thomas McIntyre Cooley, 4I AM. J. LEGAL HIST. 368 (1997); Eben Moglen, Holmes's Legacy and the New Constitutional History, I08 HARV. L. REv. 2027 (I995); Robert C. Post, Defending the Lifeworld: Substantive Due Process in the Taft Court Era, 78 B.U. L. REV. I489 (1998); and Stephen A. Siegel, Lochner Era Jurisprudence and the American Constitutional Tradition, 70 N.C. L. REV. I (I99I). For a critical review of the historiography of Lochner revisionism, $\rightarrow$ Gary D. Rowe, Lochner Revisionism Revisited, 24 LAW \& SOC. INQUIRY 22 I (I999); and for an incisive commentary on the constitutional law implications of Lochner revisionism, see Barry Friedman, 
public law emphasizes the doctrinal coherence of constitutional law in the late nineteenth and early twentieth centuries. ${ }^{210}$ Accounts of the private law of the period, in turn, focus on the creation and elaboration of a "scientific" theory of contracts. ${ }^{211}$ By contrast, the law of torts has been little discussed in the historical literature on classical legal thought. ${ }^{212}$ Yet the law of torts played a critical role in the classical conceptual system of private law. Tort law at once marked the boundaries between private individuals (separating persons from one another) and the boundary between public and private (separating individuals from the state).

The central proposition of nineteenth-century political liberalism was the idea that individuals may act as they choose, consistent with the like rights of others. In John Stuart Mill's classic formulation, "the only purpose for which power can be rightfully exercised over any member of a civilised community against his will, is to prevent harm to others."213 Similarly, for the German-born American political theorist Francis Lieber, as for American constitutional law commentators like Christopher Tiedeman, civil liberty consisted in the restraint of encroachments by one individual on the rights of another; ${ }^{214}$ in Tiedeman's words, the "right to do any thing that does not involve a trespass or injury to others." 215 The first American tort law scholars emphasized this same principle. Francis Hilliard's I859 torts treatise -

The Lesson of Lochner (Dec. Io, I999) (unpublished manuscript, on file with the Harvard Law School Library).

210 See CuSHMAN, supra note 209; FISS, supra note 209; GILLMAN, supra note 209; Kennedy, supra note 209; McCurdy, supra note 209; Siegel, supra note 209.

211 E.g., Thomas C. Grey, Langdell's Orthodoxy, 45 U. PITT. L. REV. I (I983).

212 There are important exceptions, of course. HORWITZ, TRANSORMATION II, supra note 7 , at $5 \mathrm{I}-63$, includes an excellent discussion of the doctrine of causation in the late nineteenth century. Gordon, Holmes' Common Law, supra note 209, at 727-28, 737-39, includes brief and incisive discussions of the classical legal approach to the law of torts. G. Edward White's TORT LAW IN AMERICA: AN INTELLECTUAL HISTORY (I 1980 ) also touches on some of these themes.

213 John Stuart Mill, ON LiberTy I3 (Stefan Collini ed., Cambridge Univ. Press I989) (I859).

214 See Francis Lieber, ON Civil Liberty and Self-Government 39-40 (Theodore D. Woolsey ed., 3 d ed., rev., Philadelphia, J.B. Lippincott \& Co. I877); CHRISTOPHER G. TIEDEMAN, The Unwritten Constitution of the United States: A Philosophical InQuiRy into THE Fundamentals of AMERICAN CONSTITUTIONAL LAW 76 (New York, G.P. Putnam's Sons I890) [hereinafter TIEDEMAN, UNWRITTEN CONSTITUTION] ("[T] he doctrine of natural rights may be tersely stated to be a freedom from all legal restraint that is not needed to prevent injury to others ...."); Christopher G. TIEDEMAN, A TREatise ON THE Limitations OF POlice POWER IN THE UNITED STATES CONSIDERED FROM BOTH A CIVIL AND CRIMINAL STANDPOINT, at vii (St. Louis, F.H. Thomas Law Book Co. 1886) (arguing that individual and minority rights are "free from all lawful control or interference by the majority, except so far as such control or interference may be necessary to prevent injury to others in the enjoyment of their rights"); id. at 67 ("No man has a right to make such a use of his liberty as to commit an injury to the rights of others."); see also id. $\S 30$, at $64-68$.

215 TIEDEMAN, UNWRITTEN CONSTITUTION, supra note $2 \mathrm{I} 4$, at 76. 
the first in the English language - announced that "the liability to make reparation" rested "upon an original moral duty, enjoined upon every person, so to conduct himself or exercise his own rights as not to injure another."216 Similarly, Michigan law professor, judge, and nationally renowned tort jurist Thomas Cooley explained that civil liberty was properly established by "such limitations and restraints" on individual action "as are needed to prevent what would be injurious to other individuals." 217

If tort law marked the bounds of individuals' liberty, it also separated the private sphere of individual action from the public sphere of state coercion. Self-help in the enforcement of legally defined boundaries between individuals was not an option, for obvious reasons. ${ }^{218}$ Liberalism therefore required a state. Yet the creation of the state generated additional difficulties for the preservation of civil liberty. As Lieber observed, liberalism entailed the protection of the individual not just against the encroachments of other individuals, but also against the state itself. ${ }^{219}$ Tort law thus needed to articulate a boundary between the public and private spheres, as well as the bounds of private rights as between persons. The law of torts, in short, stood as the keystone of classical legal thought's conceptual architecture.

The burden of the law of torts in classical legal thought, then, was no less than to elaborate a conceptual framework that allowed each person the free exercise of his rights consistent with the like free exercise of others' rights. But therein lay an insuperable dilemma. On the one hand, the free exercise of a person's rights could (and did) generate causal ripples outside one's own sphere of autonomous action. Often these causal effects caused injury to others, despite the exercise of reasonable prudence and care to avoid such injuries. If the harms thus caused were chargeable back to the actor, his own sphere of autonomous action would be compromised. On the other hand, a person freely exercising his rights could himself be the victim of injury caused by the reasonable and prudent exercise of the rights of others. If harms thus caused were not compensable, his sphere of autonomous action too would be cast into doubt.

Accordingly, those who articulated classical tort law faced an ongoing problem in elaborating the principles of a liberal approach to accidents for cases of nonnegligent harms to faultless victims. A negligence standard would allow individuals to act freely within their

\footnotetext{
216 I HILLIARD, supra note 44 , at 82.

217 Thomas M. CoOley, The General Principles of Constitutional LaW IN ThE UNITED STATES OF AMERICA 226 (Boston, Little, Brown \& Co. I880).

218 Cooley explained that self-help "would be subversive of civil government" in all but a narrow, sharply limited class of cases. COOLEY, supra note 46 , at 45 .

219 LIEBER, supra note 2 I 4, at 39-40.
} 
rights, without compromising those rights by charging them with the costs of harms that they could not reasonably avoid. But such a negligence standard would also leave remediless the faultless victim of harm caused by someone else's free exercise of rights. A strict liability standard, by contrast, would rectify such harms but would also impose charges on the free exercise of the nonnegligent injurer's rights.

In the case of the faultless victim of nonnegligent harm, liberal principles were indeterminate. The rights claims of injurers could be rearticulated as the rights claims of victims. A negligence standard for injurers was a strict liability standard for victims, because it imposed costs on them in the absence of negligence. A strict liability standard for injurers, in turn, was a negligence standard for victims, because it rectified injuries only in the absence of fault on the part of the victim. ${ }^{220}$ Neither rule offered a conceptual basis for carving out coherent spheres of individual autonomy.

\section{B. Elaborating Classical Tort Law}

I. Damnum Absque Injuria: Defining the Bounds of Rights and Duties. - A long-established maxim of the common law held that there could be no wrong without a remedy; Chief Justice John Marshall had rested a key point in Marbury $v$. Madison on this proposition. ${ }^{221}$ But the preoccupation of the first generation of torts treatise writers was to show that the maxim was inaccurate as a description of the law of civil wrongs. Indeed, at the heart of classical tort law was the adoption and explanation of the category of damnum absque injuria, or loss without a legal remedy. C.G. Addison, for example, began his 1870 torts treatise with the proposition that there were injuries that had no legal remedy, ${ }^{222}$ and he went on to set out the "many cases where persons have suffered serious injury from the acts and doings of others of which the law takes no cognizance."223 Francis Hilliard, too, laid out numerous cases of interpersonal damages without a remedy at

\footnotetext{
220 For examples of this argument in today's tort theory literature, see JULES L. COLEMAN, MARKETS, MORALS AND THE LAW I 74-80 (1988); JULES L. COLEMAN, RISKS AND WRONGS 22930 (1992); and Guido Calabresi \& Alvin K. Klevorick, Four Tests for Liability in Torts, I4 J. LEGAL STUD. 585, 587-9I (I985). Of course, a strict liability standard for injurers is a negligence rule for victims only if a victim's contributory negligence is a defense to liability for the injuries.

221 Marbury v. Madison, 5 U.S. (I Cranch) $137,{ }_{3} 63$ ( 1803 ) "The very essence of civil liberty certainly consists in the right of every individual to claim the protection of the laws, whenever he receives an injury.").

222 See ADDISON, supra note 45, at 2 (discussing "damage without wrong").

223 Id. at 43.
} 
law, ${ }^{224}$ as did Shearman and Redfield in their influential 1869 treatise on negligence cases. ${ }^{225}$

The negligence standard itself generated the most important class of injuries without remedy. The first and primary category of "excusable trespasses" in James Barr Ames and Jeremiah Smith's casebook, which was in use at Harvard Law School from I874 until the end of the century, consisted of injuries from mere "accident and mistake."226 Yet in the case of the faultless victim of nonnegligent harm, the law's creation of a class of damnum absque injuria posed a difficult conceptual problem: what principle could allow one person to cause injury to another without compensating the victim? Some, like Clarke Butler Whittier of Stanford Law School, simply saw shifting the cost of injuries from one undeserving person to another as a useless incurring of administrative costs. ${ }^{227}$ Oliver Wendell Holmes, at once an architect of classical legal thought and its greatest critic, observed that the "prevailing view" in I88I was that the "cumbrous and expensive machinery" of the state "ought not to be set in motion" merely to shift costs among equally undeserving individuals. ${ }^{228}$ Others saw in strict liability a standard that would threaten to bring all economic action to a halt: "We must have factories, machinery, dams, canals and railroads," explained New York Judge Robert Earl in defense of the negligence standard. ${ }^{229}$ Holmes similarly pointed out that as "the public generally profits by individual activity," there was "obviously no policy in throwing the hazard of what is at once desirable and inevitable upon

224 I HILLIARD, supra note 44, at I I9 ("It is further said, that the maxim, so use your own that you injure not another's property, is supported by the soundest wisdom. But the injury intended is a legal injury; an invasion of some legal right ....") (footnote omitted); see also id. at I I9-2 I (listing instances of damnum absque injuria).

225 See SHEARMAN \& REDFIELD, supra note 46. Cooley neatly solved the contradiction between the competing maxims by explaining that the maxim of no wrongs without a remedy was "a mere truism" that stated only the tautological claim that rights and remedies were reciprocal. COOLEY, supra note 46, at I9. The law provided remedies only for the defense of rights, but a right, in turn, was defined as that for which the law provided a remedy. Id. at 20. Under this approach, no legal wrong was without a remedy, but thus reformulated, the common law maxim was trivial.

226 i JAMEs BARR AMES \& JEREMiah SMith, A SElEction OF CASES ON THE LAW OF TORTS 56-76 (Cambridge, Harvard Law Review Publ'g Ass'n, 2d ed. 1893).

227 See Whittier, supra note 206 , at 335.

228 HOLMES, supra note 38 , at 77.

229 Losee v. Buchanan, 5I N.Y. 476, 484 (I873); see also Ryan v. N.Y. Cent. R.R. Co., 35 N.Y. 2 IO, $2 \mathrm{I} 6-\mathrm{I} 7$ (I866) (arguing that "[i]n a country where wood, coal, gas and oils are universally used," a strict liability standard would "create a liability which would be the destruction of all civilized society"). Judge Earl served on the New York Court of Appeals until the court's reorganization in 1867 , at which time the judges on the old court were reassigned to the new Commission on Appeals, charged with deciding the backlog of cases that had accumulated under the prior court. See 2 ChARles Z. LinCOlN, ThE CONSTITUTIONAL HISTORY OF NEW YORK 262-63 (rgo6). 
the actor."230 Even Seymour Thompson, editor of the American Law Review and a progressive voice in the American legal profession, argued that the "law justly ascribes" the consequences of nonnegligent harms "to inevitable misfortune, or to the act of God, and leaves the harm resulting from them to be borne by him upon whom it falls."231 Any contrary rule, Thompson contended, would "impose so great a restraint upon freedom of action as materially to check human enterprise."232 Thus, individuals were not responsible for any damage they accidentally and unavoidably did to their neighbor. ${ }^{233}$ Still others contended, often in ways that overlapped with the utilitarian arguments of Earl, Holmes, and Thompson, that the negligence standard rested in an imagined social contract: individuals gave up their "natural rights" to the inviolability of person and property in return for the like abandonment of rights by their neighbors. ${ }^{234}$

At the core of these defenses of the negligence standard in classical legal thought was the sense that a strict liability standard threatened to collapse the distinction between public and private. It is a striking fact that the leading libertarian torts theorist of the late twentieth century, Richard Epstein, advocates a strict liability standard. ${ }^{235}$ As commentators have observed, Epstein's cause-based liability standard requires significant state intervention to enforce loss-shifting as between equally faultless parties - curiously, perhaps, given his libertarian politics. ${ }^{236}$ Much like Epstein, classical torts lawyers sought to construct a liberal torts jurisprudence that would guarantee liberty within the bounds of a set of lines drawn around the individual. Unlike Epstein, however, the late nineteenth-century bar believed that the threat to the private sphere represented by state intervention required the adoption of a negligence standard rather than a strict liability approach. "The human mind, from its limitedness of vision," explained

230 HOLMES, supra note 38 , at 77.

2312 Seymour D. Thompson, The LaW of Negligence in Relations Not Resting IN CONTRACT 1234 (St. Louis, F.H. Thomas \& Co. 1880). For a discussion of Thompson as a legal progressive, see PAUL, supra note 208, at 43-44, 54-60, 22 I. See also GillmaN, supra note 209, at I I5-I 6.

2322 THOMPSON, supra note $23 \mathrm{I}$, at 1235.

233 See id. at I234-35.

234 See, e.g., Losee, 5 I N.Y. at 484.

235 See, e.g., Richard A. Epstein, A Theory of Strict Liability, 2 J. LEgAL STUD. I5 I, 203-04 (I973); see also ROBERT NOZICK, ANARCHY, STATE, AND UTOPIA 54-87 (1974) (discussing the theoretical underpinnings of punishment and compensation).

236 See George P. Fletcher, The Search for Synthesis in Tort Theory, 2 LAW \& PHIL. 63, 69-70 (1983) ("The [strict liability standard] calls into question [Epstein's] well-known reputation as a libertarian legal theorist. The argument that harm to the victim can be converted into the defendant's own harm suppresses the reality of the state's intervention to shift the loss."). Epstein, of course, might contend that the rules would be self-enforcing or that individuals would adopt private contractual arrangements. This response would surely underestimates the work that the state would have to do in enforcing the strict liability system. 
Francis Wharton, "is incapable of perfect diligence."237 Minor mistakes were thus inevitable in the private lives of individuals. Similarly, Holmes suggested that the principle of strict liability for injuries would "make a defendant responsible for all damage, however remote, of which his act could be called the cause."238 But if minor mistakes, chance injuries, and remote damages licensed the state to intervene in the private realm, there could be little or no room for individual action free from state control. If, as Holmes suggested, "[s]tate interference is an evil, where it cannot be shown to be a good,"239 then state shifting of costs among equally faultless parties merely threatened to overextend the state into the private sphere. A cause-based strict liability standard, in short, involved the state in pervasive and ongoing reallocation of resources in the private sphere.

By contrast, a negligence standard appeared to guarantee that individuals in the private sphere would be insulated from state interference in the exercise of their rights. So long as actors causing damages remained within the bounds of their legal rights, they were no more at fault than faultless victims. "No one is responsible for an injury caused purely by inevitable accident, while he is engaged in a lawful business," explained Thomas Shearman and Amasa Redfield. ${ }^{240}$ So long as an injury was the result of a "lawful act, done in a lawful manner," wrote C.G. Addison, "there is no legal injury, and no tort giving rise to an action for damages." 241 In Minnesota lawyer Edwin Jaggard's formulation, "[t]he exercise of ordinary rights" was not actionable "even if it causes damages." 242 It was only when one went outside of one's own sphere of autonomy and thus inflicted a "legal injury" or an "invasion of some legal right," clarified Hilliard, that one incurred liability for damages. ${ }^{243}$

237 Francis Wharton, A Treatise on the Law of Negligence $\S 66$, at 67 (Philadelphia, Kay \& Bro. I874).

238 HOLMES, supra note 38 , at 73 . Holmes explained that the standard of strict cause-based liability "when [an] act has brought force to bear on another through a comparatively short train of intervening causes, in spite of [an actor's] having used all possible care" required "the same liability, however numerous and unexpected the events between the act and the result." Id. at 74 . On the development of new ideas about remote causation, see HORWITZ, TRANSFORMATION II, supra note 7, at 5 I-63; Herbert Hovenkamp, Pragmatic Realism and Proximate Cause in America, $3 \mathrm{~J}$. LEGAL HIST. 3, I6-I8 (I982); and HASKELL, supra note 58, at 240-56 (describing changing ideas about causation in late nineteenth-century America).

239 HOLMES, supra note 38 , at 77.

240 SHEARMAN \& REDFIELD, supra note 46 , at 3.

241 ADDISON, supra note 45, at 2.

242 I EdWin A. JAGgard, HAND-Book of the LaW OF TORTS i45 (St. Paul, West Publ'g Co. 1895).

243 I HILlIARD, supra note 44, at I I 9 ; see also Victory v. Baker, 67 N.Y. 366 , 368 (I876) ("[I]f, in the lawful exercise of [the defendant's property] right, and without negligence on his part, a third person sustains an injury from its use by the owner, the owner is not answerable."); Munger v. Tonawanda R.R. Co., 4 N.Y. 349, 360 (I850) ("[A]s the defendants [a railroad company] were in the 
No one better captured the way in which the negligence standard functioned to protect the distinction between public and private than Michigan jurist Thomas Cooley. ${ }^{244}$ Cooley grew up in the famous "Burned-Over District" of western New York, and his upbringing appears to have left its mark on the mature jurist. Upstate New York in the I83os had been home to Martin Van Buren and the New York wing of Jacksonian democratic politics. ${ }^{245}$ Moreover, as a young man in the District, Cooley witnessed first-hand the raging evangelical movements sweeping through the Erie Canal area in the I830s. ${ }^{246}$ As historian Peter Walker writes, "[t]he most extravagant religious revivalism, antimasonry, abolition, millennialism, prohibition, spiritualism, woman's rights, the Mormon church, the Millerities, either in their origins or their first significant manifestations converged in the BurnedOver District."247 These reform movements clustered around attempts to free the individual to make self-determining choices. ${ }^{248}$ In Walker's explanation, "the common lesson taught in the district" was that the good life "depended upon the actions of autonomous man." 249

In Cooley's famous treatise on Constitutional Limitations, it was Cooley's background in the politics of antebellum Jacksonian democracy that came through most strongly. Constitutional Limitations emphasized the dangers of legislation that extended special privileges to

lawful exercise and enjoyment of their rights ... the law did not enjoin it as a duty on the defendants to take care not to injure [the plaintiffs' oxen which had wandered onto the tracks]."). The attempt to rest tort decisions on the lawful exercise of one party's rights was especially apparent in landowner liability cases, in which the plaintiff's relationship to the boundaries of the defendant's sphere of sovereign property ownership was the critical factor. See, e.g., Flanagan v. Atl. Alcatraz Asphalt Co., 56 N.Y.S. I8, 2 I (App. Div. I899); Sterger v. Vansicler, 30 N.E. 987,989 (N.Y. I892).

244 Cooley was born in 1824 , the tenth of fifteen children in a prosperous farming family. By the mid-I 840 , Cooley had moved to the rural village of Adrian, Michigan, and opened up a law practice. After joining and organizing for the Free Soil Party and later the Republican Party, Cooley managed to get appointed to draft a compilation of the state's statutes. His work on the statutory compilation, in turn, led to appointments to the University of Michigan Law School faculty and in I 864 to the Michigan Supreme Court. With the publication of the I 868 treatise Constitutional Limitations, JOSEPH STORY, A TREATISE ON CONSTITUTIONAL LIMITATIONS (Thomas M. Cooley ed., Boston, Little, Brown \& Co. I 868), Cooley became a nationally recognized jurist. Cooley followed Constitutional Limitations with a treatise on taxation, THOMAS COOLEY, A TREATISE ON THE LAW OF TAXATION INCLUding THE LAW OF SPECIAL ASSESSMENTS (I876). Then, in I879, Cooley published a treatise on torts. See COOLEY, supra note 46.

245 See ARTHUR M. SChlesinger, JR., THE AGE OF JACKSON, I 77-80 (I 945 ).

246 Peter F. Walker, Moral Choices: Memory, Desire, and IMAGination IN NiNeTEENTH-CENTURY AMERICAN ABOLITION 338 (I978).

247 Id. at 337; see generally WHITNEY R. CROSS, THE BURNED-OVER DISTRICT: THE SOCIAL AND INTELLECTUAL HISTORY OF ENTHUSIASTIC RELIGION IN WESTERN NEW YORK, I800-1850 (I950); PAUl E. JOHNSON, A SHOPKEEPER'S MILLENNIUM: SOCIETY AND REVIVALS IN ROCHESTER, NEW YORK, I815-I837 (I978).

248 See WALKER, supra note 246 , at 337-39.

249 Id. at 338. 
some and jeopardized the principle of equal rights for all. ${ }^{250}$ Cooley's torts treatise, by contrast, drew inspiration from the Burned-Over District's reform ideal of moral autonomy. So long as an actor remained within the bounds of his legal rights and duties he was, in Cooley's conception, unchargeable by the state for harms falling on others. Thus the "lawful and proper exercise by one man of his rights" was never grounds for liability. ${ }^{251}$ In Cooley's view, then, the faultless victims of purely "accidental" injuries were without legal recourse because there existed no "injuria" - no legal wrong - that the state could attach to another actor. ${ }^{252}$ To hold otherwise was to threaten state infringement of individual autonomy. As Cooley explained, "[t]hat which it is right and lawful for one man to do cannot furnish the foundation for an action in favor of another." 253

2. Contributory Negligence. - Of course Cooley had not really solved the persistent problem of defining the bounds of individual liberty; he had merely restated it. Indeed, for Cooley and his peers, the faultless victim of nonnegligent harm remained a deeply destabilizing force in late nineteenth-century tort law. Much of the doctrinal edifice of the law of torts in the late nineteenth century can thus be understood as a series of attempts to deal with the persistent problem of the faultless victim of nonnegligent harm. In particular, judges and commentators promulgated rules designed to highlight wrongdoing on the part of victims. If the victims of injury acted outside of the bounds of their rights and duties, after all, the conceptual dilemma of the faultless victim and the nonnegligent injurer disappeared.

Contributory negligence was probably the most important such doctrine in the late nineteenth-century law of torts.. ${ }^{254}$ In virtually every American jurisdiction a victim was unable to recover if the victim's own negligence - no matter how slight - had contributed to her injuries. $^{255}$ Thus, "[b]etween two wrong-doers," or between a nonneg-

250 See StORY, supra note 244; David J. Barron, The Promise of Cooley's City: Traces of Local Constitutionalism, I47 U. PA. L. REV. 487, 509-22 (I999); Carrington, supra note 209, at 370.

251 COOLEY, supra note 46 , at $8 \mathrm{I}$.

252 Id. at 80.

253 Id. at $8 \mathrm{I}$.

254 Peter Karsten has recently argued that historians have exaggerated the importance of contributory negligence in the nineteenth century. See KARSTEN, supra note 49 , at 95-IOI. The point here, however, is not to gauge the social consequences of the contributory negligence rule, but rather to place it in the ideological system of late nineteenth-century tort doctrine.

255 See SHEARMAN \& REDFIELD, supra note $46, \S \S 35-52$, at $35-57$. The exceptions were Illinois, Kansas, and Georgia, which in the mid-nineteenth century adopted rules allowing recovery for gross negligence even in the face of relatively slight negligence on the part of the victim. See 2 THOMPSON, supra note 23I, at I023-24; COOLEY, supra note 46 , at 676-78; SHEARMAN \& REDFIELD, supra note $46, \S 37$, at $37-38$. By the latter part of the century, however, the doctrine of contributory negligence emerged in these jurisdictions. See FrIEDMAN, supra note 8 , at 477 . Tennessee appears to have flirted with a comparative negligence standard in which the contributory neg- 
ligent defendant and a negligent plaintiff, "the law will leave the consequences to rest where they have chanced to fall."256 In case after case, the deciding question was whether any negligence on the part of the plaintiff had contributed to the injuries from which she suffered.257 Indeed, no fewer than sixty-eight percent of the negligence decisions digested by the West Publishing Company between I 860 and I 880 raised questions of contributory negligence. ${ }^{258}$ The contributory negligence rule relieved much of the pressure on the negligence standard.

3. Assumption of Risk. - In other cases of nonnegligent injuries, tort law justified the absence of a remedy by the consent of the victim to bear the risk of accident. The doctrine of assumption of risk attached predominantly to work accidents. Summed up in the maxim volenti non fit injuria - roughly translatable as "there is no legal injury to one who consents" - the doctrine held that "[n]o action can be maintained for damages resulting from conduct suffered by consent" of the victim. ${ }^{259}$ Though employers owed employees a duty of due care in the provision of machinery, appliances, and competent fellowservants, the doctrine of assumption of risk held that "an employer may relieve himself of all common law liability for accidents occurring to his servants, through defects in materials or in the character of fellow servants, by giving explicit warning of such defects, and notice that he does not intend to remedy them."260 Similarly, when an employee learned of defects in machinery or incompetence in his fellows, either before or during the course of his service, the employee was "deemed to assume the risk of danger thus known." 261 In some instances courts even held that the rule applied to all defects within the constructive knowledge of an employee - that is, defects not actually known to an employee, but that should have become known to the employee through "the exercise of ordinary observation or reasonable skill and diligence."262

ligence of a plaintiff was a factor for consideration in the jury's assessment of damages. See COOLEY, supra note 46 , at $677-78$.

256 COOLEY, supra note 46 , at 672 .

257 See, e.g., Dexter v. McCready, 5 A. 855 (Conn. I886); Toledo \& W. Ry. Co. v. Goddard, 25 Ind. I85 (I865); Monongahela City v. Fischer, 2 A. 87 (Pa. I886).

258 A Westlaw search of ("272K!" \& DA(AFT 1859 \& BEF I88I)), NY-CS database (Dec. 8, 2000), which produces all cases digested under the heading "Negligence" during this time period, yields 968 results. A search of ("272K!" \& (contribut!/5 negligen!) \& DA(AFT I859 \& BEF I88I)), NY-CS database (Dec. 8, 2000), which produces the subset of cases that raise the issue of contributory negligence, yields $66 \mathrm{I}$ results.

259 I JAGGARD, supra note 242 , at 199.

260 SHEARMAN \& REDFIELD, supra note $46, \S 94$, at $\mathrm{I}$ IO.

2612 THOMPSON, supra note $23 \mathrm{I}$, at I 108.

262 Id.; see also SHEARMAN \& REDFIELD, supra note $46, \S 94$, at II I ("[W] here the servant's action is founded upon the assumption that the master ought to have known of the defect which 
Tort law's resort to the implied consent of victims, however, was fraught with problems of its own. Conventional wisdom in late nineteenth-century tort law held that for reasons of public policy persons could not contract out of liability for their own negligence. Certain entitlements were simply not alienable. Such waivers of liability were suspect for arising out of coercion. Moreover, such waivers appeared to give rise to the risk of harm to third parties who might be injured by carelessness that had been licensed by a person's belief that he had been held harmless against costs arising out of his negligence. ${ }^{263}$

\section{Pressure from Below: The World of Accident Litigation and the Rise of Faultless Injuries}

Even as the elite of the American bar worked out the elaborate doctrinal structure of classical tort law, a rising tide of personal injury litigation pressed harder and harder on weaknesses in the doctrine. Hilliard wrote his torts treatise in 1859 in response to the "very large and increasing proportion of actions of tort, which are continually arising in our courts of justice."264 Twenty years later, after the publication of the third edition of Hilliard's treatise and the issuance of many additional works on the subject, Cooley decided that yet another torts treatise was warranted. The "new inventions and improvements" of the machine age, he explained, were having a "powerful tendency" to create "new occupations" and "more frequent controversies."265

What was most remarkable about tort litigation, and particularly personal injury litigation, in these years was the unprecedented character of the wave of litigation itself. Of particular interest to treatise writers like Hilliard, for example, was the problem of how to deal with the constant stream of new problems raised in torts cases, especially the continual development of new theories for causes of action. Time and again common law judges in the United States, as well as in England, were faced with new kinds of tort claims. The novelty of a particular claim or the "absence of any precedent for a particular action," Hilliard cautioned, was good but hardly conclusive evidence that a suit failed to state a cognizable claim. ${ }^{266}$ Yet it was precisely the avalanche of such novel claims that was steadily undermining the gilded structure of the law of torts. For in the middle of the nineteenth century, personal injury law underwent a paradigm shift that ushered in what

\footnotetext{
caused the injury, it is clearly a sufficient defence to show that the servant had equal means of knowledge." (citing Loonam v. Brockway, 28 How. Pr. 472 (N.Y. Sup. Ct. I864))).

263 For a discussion of the problems raised by contracting out of tort liability and the closely related assumption of risk doctrine, see infra section III.D.2.

264 I HILLIARD, supra note 44 , at $\mathrm{x}$ (emphasis removed).

265 COOLEY, supra note 46 , at I.

266 I HILLIARD, supra note 44, at 83-84.
} 
would, by the turn of the century, become a crisis for the classical legal order.

I. From Loss of Services to Loss of Wages: The Transformation of the Personal Injury Suit. - In the eighteenth-century common law, as we have seen, lawyers and judges had little occasion to discuss legal actions by the victims of personal injury. There was, however, an important category of cases that arose out of personal injuries. Personal injuries, after all, caused damages not only to the immediate victim of bodily harm, but also to a person who possessed rights in the life and services of the victim. Thus, when eighteenth-century common lawyers turned to actions for damages from personal injury, they were likely to address something quite different from the scenarios that later faced mid- and late nineteenth-century judges. In particular, eighteenth-century lawyers discussed not actions for damages for the lost wages or medical costs of the victim, but rather actions for damages to a master for the loss of services resulting from an injury to a member of the master's household. ${ }^{267}$ Tapping Reeve, the leading American authority on the law of domestic relations at the turn of the nineteenth century, explained that in the event of injury to a wife, "the husband may bring an action in his own name, to recover damages which he sustained, by reason of the battery." 268 By the same token, a father was entitled to an action "when his minor child is beaten" and the father "has lost the services of that child, or has been put to expense by means thereof." 269

267 On the action for loss of services, $\rightarrow$ John Fabian Witt, From Loss of Services to Loss of Support: The Wrongful Death Statutes, the Origins of Modern Tort Law, and the Making of the Nineteenth-Century Family, 25 LAW \& SOC. INQUIRY 7 I 7, 722-3I (2000).

268 TAPPING REEVE, THE LAW OF BARON AND FEMME; OF PARENT AND CHILD; OF GUARDIAN AND WARD; OF MASTER AND SERVANT; AND OF THE POWERS OF COURTS OF CHANCERY 63 (New Haven, Oliver Steele I8I6).

269 Id . at 20I. As one mid-nineteenth-century court observed when looking back into the history of litigation over injuries, "[n]umerous instances are to be found in the common law books of actions by masters for personal injuries to servants." Hall v. Nashville \& Chattanooga R.R. Co., I Tenn. Cases (Thompson) 204, 205 (Tenn. I859). In contrast, wives, children, and servants had no cause of action for injuries to their husbands, fathers, and masters. Blackstone observed that in cases of injury to domestic relations, only "the wrong done to the superior of the parties related" was cognizable at common law. "[T] he loss of the inferior by such injuries," however, was "totally unregarded." 3 BLACKSTONE, supra note $2 \mathrm{I}$, at * ${ }^{2} 42-43$. The rationale was simple:

[T] he inferior hath no kind of property in the company, care, or assistance of the superior, as the superior is held to have in those of the inferior; and therefore the inferior can suffer no loss or injury. The wife cannot recover damages for beating her husband, for she hath no separate interest in any thing during her coverture. The child hath no property in his father or guardian; as they have in him, for the sake of giving him education and nurture. ... And so the servant, whose master is disabled, ... suffers no injury, and is therefore intitled to no action, for any battery or imprisonment which such master may happen to endure.

Id. 
The action for loss of services had its roots in the early-modern family-based structure of production and social organization. In a household economy, the roles of wife, servant, and child were closely intertwined and often overlapping. ${ }^{270}$ Husbands expected wives and children to render service to the household, and acquired a familial authority and governance over even those household servants not related by blood. The household economy remained the central mode of economic life in the United States into the early nineteenth century. ${ }^{271}$ And in the South, of course, the household model of production persisted until the Civil War. ${ }^{272}$ Indeed, in the South, masters brought actions to recover damages from third parties and independent contractors for injuries to their slaves up until the abolition of slavery. ${ }^{273}$

In the I820S and I830s, however, the shape of economic life in the North underwent a critical shift. New mills and factories, especially in New England and New York, separated out production from the sphere of domestic life. ${ }^{274}$ In precisely the same years, the slow trickle of personal injury cases became a steady stream. ${ }^{275}$ Moreover, whereas eighteenth- and early nineteenth-century personal injury litigation generally took the form of an action for loss of services, now wage-earners with households of their own, independent of the firm

270 Thus Blackstone called them the "three great relations in private life." I BLACKSTONE, supra note $2 \mathrm{I}$, at * $4 \mathrm{IO}$.

271 See Elizabeth Blackmar, Manhattan For ReNT, I785-I850, at 5 I-60 (I989); Alan DAWLEY, Class AND COMMUNITY: THE INDUSTRIAL REVOLUTION IN LYNN I7-I8 (1976); JOHNSON, supra note 247, at 43-46; MARY P. RYAN, CRADLE OF THE MIDDle Class: THE FAMILY IN ONEIDA COUNTY, NEW YORK, I 790-I865, at 25 (I98I).

272 On household economics in the South, see generally PETER W. BARDAGLio,

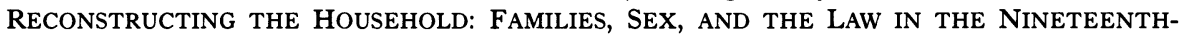
Century South (I 995); Elizabeth FoX-Genovese, Within the Plantation Household: BLACK AND WHITE WOMEN OF THE OLD SOUTH (I 988 ).

273 The contrast between ready recovery for injuries to hired-out slaves, on the one hand, and limited common law employers' liability rules for free labor, on the other hand, has been explored by a number of historians. See, e.g., ThOMAS D. MORRIS, SOUTHERN SLAVERY AND THE LAW, I6I9-I860, at I47-58 (I996); TUSHNET, supra note 22, at 45-50.

274 See, e.g., JOHNSON, supra note 247 , at 43-47; CHRISTOPHER ClARK, THE ROOTS OF RURAL CAPITALISM: WESTERN MASSACHUSETTS, I780-1860, at 94-95, IO5-06 (I990); JONATHAN PRUde, The COMING OF INDUSTRIAL ORder: TOWN AND Factory Life IN RURAL MASSACHUSETTS, I810-I 860 ( 1983 ).

275 TomLINS, supra note 7 , at 30I-03, 33I-33, 34I-47 (discussing Barnes v. Boston \& Worcester R.R. (Mass. I839) (unreported case)); see, e.g., Murray v. S.C. R.R. Co., 26 S.C.L. (I McMul.) 385 (I84I); Farwell v. Boston \& Worcester R.R., 45 Mass. (4 Met.) 49 (I842). On the novelty of this line of cases, see A.W. Brian Simpson, A Case of First Impression: Priestley v. Fowler (1837), in LEADING CASES IN THE COMmON LAW IOO, IOI, II3-29 (1995); and Epstein, supra note 19, at 777-79. 
for which they worked, brought actions to recover lost earnings, medical costs, and pain and suffering caused by injuries to themselves. ${ }^{276}$

The emerging wage system and the new structure of domestic life lay at the heart of this new form of tort litigation. ${ }^{277}$ The free wage laborer distinguished himself from the domestic household laborer of times past and the unfree laborer of the American South by virtue of his capacity to support an independent domestic sphere of his own. The free laborer incapacitated by injury thus needed some means to maintain the stream of wages in order to support his household. The tort suit offered one mechanism for providing such compensation.

2. Obstacles to Personal Injury Litigation (I): Persistent Patterns of Deference and Authority. - In addition to the growing volume of cases, what was new about mid-nineteenth-century personal injury litigation was its central concern with the means of support for wives and children. As A.W.B. Simpson observes, the rise of personal injury litigation as a provider of compensation in the event of accident accompanied the decline of traditional household-centered systems of care for the injured and sick. ${ }^{278}$ Yet the transformation hardly occurred overnight. Personal injury litigation faced a host of obstacles during this period, obstacles rooted both in cultural institutions and in legal institutions.

On the cultural side, persistent eighteenth-century patterns of authority and deference between master and servant slowed the growth of personal injury litigation. Nineteenth-century textile mills, for example, often modeled their labor management practices on the relations of authority, discipline, and deference in the household economies that they sought to replace. In Rhode Island and southcentral Massachusetts, leading textile mill entrepreneur Samuel Slater sought in his early textile mills to assert "traditional community values" through the use of a "family system" in which the mill took the place of the eighteenth-century household.279 In the New England mills of the famous Boston Associates, the "boardinghouse system" took in countless young female mill hands as the core of the

276 The Priestley case presents an interesting transitional case. It was brought by the nineteenyear-old victim's father, but apparently only because of the victim's minority; loss of services was not at issue. See Simpson, supra note 275 , at Ior.

277 The shifting paradigm in accident litigation was especially evident in wrongful death actions and in the enactment of the wrongful death statutes in the United States beginning in I847. Particularly in the United States, the wrongful death statutes were conceived as a means of providing support to widows and dependent children. $\rightarrow$ Witt, supra note 267 , at $731-46$.

278 See Simpson, supra note 275 , at $123-25$.

279 See PRUDE, supra note 274, at 36-64. The "family system" was also used in Pennsylvania textile mills. See ANThony F.C. WAllace, Rockdale: The Growth of AN American VilLIAGE IN THE EARLY INDUSTRIAL REVOLUTION I80 (I978). 
workforce. ${ }^{280}$ Like Slater's "family system," the Boston Associates' boardinghouse approach sought to "recreate the traditional communities of their childhood, communities in which corporate hierarchy and deference, as well as neighborliness, were valued."281 In Philadelphia's textile mills, by contrast, numerous small mill owners eschewed the family or boardinghouse approaches. But here, first-generation immigrant mill owners drew on traditions of guild obligation to create a very similar ethos of employer paternalism. ${ }^{282}$

Personal injury litigation was thus exceedingly rare in the Northern textile mills of the early to mid-nineteenth century. ${ }^{283}$ To be sure, personal injury litigation was rare in textile mills partly because the mills did not present quite the same danger as the railroads and the mines. Yet as Herman Melville observed in his use of the textile factory steam engine as an extended metaphor for the dangers of the whaling boat in Moby-Dick, whirring bobbins and shuttles surely presented special dangers of their own. ${ }^{284}$ In any event, the various brands of employer paternalism in the mills often led, as in Lowell, Massachusetts, to employer relief plans designed to aid disabled employees. ${ }^{285}$

In many instances, the apparent scarcity of personal injury litigation arising out of the textile mills was due less to employer paternalism than to the domination of labor markets and entire towns by particular employers or groups of employers. In isolated mill towns, suing an employer often meant antagonizing the most powerful men in the region and jeopardizing not only one's employment prospects, but also one's housing, church membership, and even access to town poor re-

280 Robert F. Dalzell, JR., Enterprising Elite: The Boston Associates and the WORLD THEY MADE 33 ( 1987 ).

281 Teresa ANne MURPhy, Ten Hours' Labor: Religion, Reform, and Gender in EARLY NEW ENGLAND 20 (I992); see also DALZELL, supra note 280, at 3 I-36 (discussing the labor philosophy of the Boston Associates).

282 See Philip Scranton, Varieties of Paternalism: Industrial Structures and the Social Relations of Production in American Textiles, 36 AM. Q. 235 (1984); see also PHILIP SCRANTON, PRO-

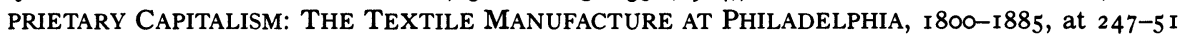
(I983) (discussing paternalism in small Philadelphia textile mills).

283 All that we can say for certain at this point is that there appear to be no reported accident cases arising out of the early textile mills.

284 See HeRman Melville, MOBY-Dick 287 (Arion Press I979) (I85I) ("For, when the line is darting out, to be seated then in the boat, is like being seated in the midst of the manifold whizzings of a steam-engine in full play, when every flying beam, and shaft, and wheel, is grazing you."). Lewis Hine's photographs of injured workers at the turn of the twentieth century also make readily apparent the horrific harm that textile machinery could inflict on the hands and forearms of child laborers.

285 The relative lack of danger in the textile mills compared to the railroads and mines meant that employer relief plans in paternalistic mills took the form of sickness relief rather than accident or disability relief. Yet the plans were no doubt useful to the victims of injury in work accidents. See Abel C. Thomas, Plan for Mutual Relief (I840), in THE LOWELl OfFERING: WRITINGS BY NEW ENGLAND MILL WOMEN (1840-1845), at I99, I99-200 (Benita Eisler ed., I977) (arguing that an employer relief plan was needed and could be financed by small monthly wage deductions). 
lief. As one turn-of-the-century labor union leader observed, "when a workman goes to law with his employer, he, as it were, declares war against the person on whom his future probably depends."286 The result was that workers only brought legal claims "when the injury [was] very great" and the worker was prepared to leave the employer's service. ${ }^{287}$ In many textile mill company towns, workers would have been reluctant to bring suit even in these circumstances. The "family system" of mill hiring meant that very often multiple members of a single family worked under the roof of a single mill; litigating work accidents in such circumstances might have meant abandoning not one but several jobs. ${ }^{288}$ Moreover, from early in the nineteenth century, textile entrepreneurs from Rhode Island and Massachusetts to the Carolinas had built their mills in isolated "factory villages" where they owned the local stores, housing stock, and schools, as well as much of the real estate for miles around. ${ }^{289}$ Labor markets in towns such as Lowell, Massachusetts; ${ }^{290}$ Philadelphia's Manayunk section;291 and southern towns such as Lancaster, Rock Hill, and Clinton, South Carolina, for example, were dominated by single cotton mills. ${ }^{292}$ Similarly, in the 1830 s the textile mills in south-central Massachusetts employed nearly two and a half times as many workers as worked in the region's entire nontextile sector. ${ }^{293}$ Furthermore, mills in a given region often entered into agreements not to hire workers who had

286 GeORge E. MCNEILl, A STUdy OF ACCIDENTS AND ACCIDENT INSURANCE I 29 (I900) (internal quotation marks omitted).

287 Id.

288 On the increasing prevalence of the family-based approach in the Lowell mills as the labor market for young single native women declined, see THOMAS DUBLIN, WOMEN AT WORK: THE TRANSFORMATION OF WORK AND COMMUNITY IN LOWELL, MASSACHUSETTS, $1826-1860$, at 138 (1979). On the family system in south-central Massachusetts and Rhode Island, see PRUDE, supra note 274 , at 43,87 , which observes that by $183 \mathrm{I}$ about two out of three workers in Slater-owned mills had a family member working in the same mill.

289 Slater built the town of "Slatersville" for one of his early mills. PRUDE, supra note 274, at 48; see also DAVID L. CARLTON, MILl AND TOWN IN SOUTH CAROLINA, I880-1920, at 89-109 (1982) (describing South Carolina mill towns and the mills' control of housing, churches, stores, and schools); DUBLIN, supra note 288 , at 75-77 (describing the broad vision of corporate paternalism and practices of company housing in Lowell mills); JACQUELYN DOWD HALL, JAMES LELOUDIS, ROBERT KORSTAD, MARY MURPHY, LUANN JONES \& CHRISTOPHER B. DALY, LIKE A FAMILY: THE MAKING OF A SOUTHERN COTTON MILL WORLD (1987) (describing mill towns in North Carolina).

290 See DUBLIN, supra note 288 , at 75-76.

291 See Cynthia J. Shelton, The Mills of Manayunk: Industrialization and Social CONFLICT IN THE PHILADELPHIA REgION, I787-I837, at IO0-OI (I986) (explaining that mill hands in Manayunk typically depended on the same mill owner for employment, housing, access to church membership, and access to poor relief).

292 See CARLTON, supra note 289 , at 52-53.

293 PRUDE, supra note 274 , at $7 \mathrm{I}$. 
worked in another mill unless the worker had received an honorable discharge from the prior mill. ${ }^{294}$

Manchester, New Hampshire, for example, was designed by the Boston Associates as a company town for the Amoskeag mills. 295 Though Manchester itself quickly grew into a town in its own right, the company's influence persisted well into the twentieth century. For close to a century, two thirds of the employment opportunities in Manchester remained dependent in some way on the company. ${ }^{296}$ As Amoskeag's historians Tamara Hareven and Randolph Langenbach explain, "[t]here was hardly a person in Manchester between I838, when construction began, and I936, when the mills shut down, whose life was not in some way affected by the Company."297 Between the company's domination of the local labor market and the company's aggressive employee welfare plans, which were formalized late in the century, the Amoskeag mills succeeded in creating an atmosphere marked by considerable, if often reluctant, deference to management among the workforce. ${ }^{298}$ In the words of one Manchester resident and Amoskeag employee: "If you told the boss to go to hell, you might as well move out of the city. The boss had the power to blackball you for the rest of your days."299

In industries characterized by such local power in the labor market, injured workers were often forced to appeal to their employers for assistance rather than risk suing them. Early in the nineteenth century, laborers on canal digs injured in blasting accidents in isolated camps, for example, appealed to their employers for assistance. ${ }^{300}$ Later in the century at Amoskeag, appeals to the mill rather than litigation characterized the aftermath of work accidents. ${ }^{301}$ As one employment office clerk at Amoskeag during the first decade of the twentieth century remembered, injured employees brought lawsuits "every once in a while." ${ }^{02}$ In general, however, the company "worked out" a settle-

294 See DUBLIN, supra note 288 , at 59.

295 TAmara K. HAReven, FAmily Time and Industrial Time: The Relationship BeTWEEN THE FAMILY AND WORK IN A NEW ENGLAND INDUSTRIAL COMMUNITY 9-IO (I982).

296 Id. at 14.

297 TAMARA K. HAREVEN \& RANDOLPH LANGENBACH, AMOSKEAG: LifE AND WORK IN AN AMERICAN FACTORY-CITY I I (1978).

298 See HAREVEN, supra note 295, at 38-68.

299 HAREVEN \& LANGENBACH, supra note 297, at II. Worker deference to the company was a complex combination of sincerely held affective bonds on the one hand, and rational calculation as to the power of the company over workers' lives on the other hand. As Hareven and Langenbach explain, workers not only feared the power of the company, but developed "a strong identification with the corporation." Id.

300 See Peter Way, Common Labour: Workers and the Digging of North AMerican CANALS, I 780-I860, at I48-5 I (I993).

301 See HAREVEN \& LANGENBACH, supra note 297 , at I33.

302 Id. 
ment with injured workers who were presumably loathe to sue the city's most important establishment. ${ }^{303}$ Similar practices characterized dominant firms in the Pittsburgh steel industry; by the end of the century, the crippled watchman had become a "social type" as steel mill owners put disabled workingmen in low-exertion jobs. ${ }^{304}$

Mining often involved even more isolated working conditions than those found in the textile mills. Moreover, mining, along with railroad work, was one of the two most dangerous occupations in the mid- and late nineteenth century. Yet in large part because of the isolation and local power of many mining companies, mining accidents never became as important as railroad accidents in the development of nineteenth-century tort law. ${ }^{305}$ Some historians, to be sure, have suggested that company mining towns were not as despotic as has usually been thought - at least not relative to the alternatives available to the working class families who lived in them. ${ }^{306}$ Nonetheless, the local power of mining companies appears often to have been enough to deter the filing of lawsuits by accident victims and their families in mining communities around the country. In the intermountain West between the eastern slope of the Rockies and the Sierra Nevadas, coal mine operators controlled as much as a fifth of the total labor market and often collaborated among themselves on hiring practices. ${ }^{307}$ In many frontier mining camps, the absence of government was the camps' most striking characteristic. ${ }^{308}$ Mine operators backed by state troops and private police were virtually unchallengeable in company mining towns such as the fenced and guarded Thurber, Texas. ${ }^{309}$ Company towns in the bituminous coal fields of western Pennsylvania, southern Appalachia, and northern Illinois were dominated by mining

303 Id.

304 See EASTMAN, supra note I64, at I56.

305 Even a cursory glance at the treatises on tort law readily suggests the importance of railroad cases and the extreme paucity of mining cases. By another measure, the West Publishing Company digested only six mining-related personal injury cases before 1900 in the mining state of Pennsylvania as compared with 203 railroad cases involving injuries to persons on or near the tracks - a category that excluded passenger and work accidents. Search of Westlaw, PA-HN-ALL database (Dec. 2, 2000) (search of cases containing "260w I 8 " or " $320 x(G)$ " in the TOPIC field and "BEF I900" in the DATE field). Even as late as 1907 , individual mining disasters generated little litigation. See, e.g., HARVEY, supra note 200 , at $4 \mathrm{I}-42$.

306 See CRANDAll A. Shifflett, COAL TOWNS: Life, Work, AND Culture In Company

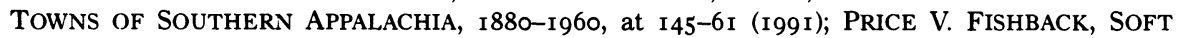
COAL, HARD CHOICES: THE ECONOMIC WELFARE OF BITUMINOUS COAL MINERS, I890-I930, at I52-70 (I992).

307 See RONALD C. BROWN, HARD-ROCK MINERS: THE INTERMOUNTAIN WEST, I860-I920, at I3, I 28 (1979).

308 See Elizabeth Jameson, All That Glitters: Class, Conflict, and Community in CRIPPLE CREEK 53-59 (I998) (describing altercations between mine owners and striking miners).

309 See John S. SPRATT, SR., Thurber, TeXas: The LIFE AND DEATH OF A Company COAL Town, at xix, 6, I 3 (Harwood P. Hinton ed., I986). 
companies that owned the local real estate, housing stock, roads, and stores. ${ }^{310}$ Even where no single mining company became dominant, as in the famed anthracite fields of northeastern Pennsylvania, personal injury litigation was often futile. In a region in which the average duration of any one mining enterprise was less than one year, the short lifespan of anthracite mining operations made employers effectively judgment proof; most mines would have closed down long before the resolution of any legal action. ${ }^{311}$

3. Obstacles to Personal Injury Litigation (II): The Law of Evidence. - If patterns of authority, deference, and power inhibited the growth of personal injury litigation, the law itself presented a number of doctrinal obstacles to bringing accident cases in the middle of the nineteenth century. We have already seen that the substantive doctrines of liability in tort were sharply limited during the period. The negligence and contributory negligence standards, supplemented by the assumption of risk and fellow servant rules in the critical category of work accident cases, surely served to deter many would-be claimants. Moreover, quite apart from substantive rules of tort liability, a number of procedural doctrines discouraged accident litigation.

No set of procedural rules presented more problems for would-be personal injury plaintiffs than the law of evidence did. For much of the nineteenth century, an array of witness disqualification rules barred testimony from precisely those most likely to know what had happened: the parties, any real parties in interest, any interested witnesses, and the husbands and wives of the parties. Eighteenth-century English treatise writer Lord Chief Baron Jeffrey Gilbert had explained that certain classes of persons were "totally excluded from all Attestation ... for want of Integrity and Discernment."312 Among these were the insane; 313 those convicted of "Falsehood and other Crimes against the common Principles of Honesty," so-called "crimen falsi"; 314 and religious nonbelievers, whose oaths to tell the truth were meaningless. ${ }^{315}$ Most important in Gilbert's account, however, were those witnesses whose interest in a suit was a "Ground for Distrust," either because

310 See Mildred Allen Beik, The Miners of Windber: The Struggles of New IMMIGRANTS FOR UNIONIZATION, I890S-I930S, at I8 (I996); JOHN H.M. LASLETT, NATURE'S NOBLEMEN: THE FoRTUNES OF THE INDEPENDENT COLLIER IN SCOTLAND AND THE AMERICAN MIDWEST, I855-I889, at 42-43 (1983); PRISCILla LONG, WHERE THE SUN NEVER ShINES: A HISTORY OF AMERICA's BLOODY COAL INDUSTRY 80 (I989); SHIFFLETT, supra note 306, at I45-6I.

311 See WALlACE, supra note $\mathrm{I} 4$, at $258-6 \mathrm{I}$.

312 ANON. [Sir Geoffrey Gilbert], THE LAW OF EvidENCE 86 (photo. reprint 1979) (Dublin, I754).

313 See id. at 103-04.

314 Id. at I00-OI.

315 See id. at Io3. 
they were the actual parties to the action or merely because they stood to gain or lose depending on its outcome. ${ }^{316}$

The disqualification rules laid down by Gilbert were readily adopted by American courts in the early republic. ${ }^{317}$ The result, as legal historians John Langbein and William Nelson have each observed, was the effective exclusion from the common law courts of cases that would have relied on oral testimony. ${ }^{318}$ Oral contracts made without a witness, for example, were exceedingly difficult to sue on, for neither the plaintiff nor the defendant could testify to the making of the contract. ${ }^{319}$ By the same token, actions arising out of accidental injuries were required to go forward (if at all) without the testimony of the person who as often as not knew best what had happened. 320 One can only imagine how difficult it was to bring an action in railroadcrossing cases occurring on isolated stretches of track, with few or no witnesses. Similarly, in work accident cases, a disabled worker unable to testify on his own behalf relied by necessity on the testimony of his fellow employees, all of whom would presumably be reluctant to testify against their employer if they wished to keep their jobs on good terms. As two early twentieth-century observers noted, it was quite common for coworkers to "refuse to testify against their employer through fear of being dismissed from employment." 321

By the I840s, law reformers in the United States began to abolish the witness disqualification rules. Massachusetts courts had gradually narrowed the rules for several decades; ${ }^{322}$ the Supreme Judicial Court abolished the disqualification of atheists in $1818,{ }^{323}$ and by the $1820 \mathrm{~S}$ the agent of a party could testify to the contents of contracts made on behalf of his principal. ${ }^{324}$ Moreover, in many states legislation abolished the disqualification rules for particular kinds of cases, including suits on gaming debts $^{325}$ and actions to collect allegedly usurious

\footnotetext{
316 Id. at 87.

317 See, e.g., Starr v. Tracy, 2 Root 528, 529 (Conn. Super. Ct. I797); Connor v. Bradey, I Ant. N.P. Cas. 99, 99-100 (N.Y. Sup. Ct. I809); see also ZEPHANIAH SWIFT, A DigEST OF THE LAW OF EVIDENCE, IN CIVIL AND CRIMINAl CASES, AND a TREATISE ON BILls OF EXCHANGE AND PROMISSORY NOTES 44-73 (Hartford, Oliver D. Cooke I8IO).

318 See William E. Nelson, americanization of the Common laW: The Impact of Legal Change ON MASSAChuSETTS Society, i 760-1830, at 24-25, i56 (I975); John H. Langbein, Historical Foundations of the Law of Evidence: A View From the Ryder Sources, 96 COLUM. L. REV. I I68, I I 74-75 (I996).

319 See NELSON, supra note 318 , at 60, 156.

320 See Langbein, supra note 3 I 8 , I 174 .

321 Clyde J. Crobaugh \& Amos E. Redding, Casualty Insurance 495 (ig28).

322 NELSON, supra note 318 , at $156-57$.

323 See Hunscom v. Hunscom, I5 Mass. (I4 Tyng) I84, I84 (1818).

$324 C f$. NELSON, supra note 318 , at $156-57$ (noting that exceptions to the rule prohibiting interested parties from testifying made the rule virtually meaningless).

325 See An Act to Prevent Excessive and Deceitful Gaming, ch. 46, I801 N.Y. Laws 70.
} 
loans. ${ }^{326}$ The core of the disqualification rules remained intact, however, into the I840s and I850s.327 General statutory abolition of the disqualification rules began in Michigan, which abolished the disqualification rule for nonparty interested witnesses in $1846 .{ }^{328}$ Connecticut admitted party testimony in civil cases in $1848 .^{329}$ New York abolished the disqualification of interested nonparty witnesses in the famous Field Code of that same year. ${ }^{330}$ The Code also allowed parties to call their opponents to testify, ${ }^{331}$ and in 1857 New York allowed parties to testify on their own behalf. ${ }^{332}$ Massachusetts, following close behind, abolished its party disqualification rules in 1857 as well. ${ }^{333}$ And though Southern states took longer than Northern states to abolish the disqualification rules, the entire array of disqualification rules collapsed by the 1870 s. $^{334}$

Although the witness disqualification rules no longer hindered personal injury litigation in most Northern states by the end of the $1850 \mathrm{O}$, the mid-nineteenth-century law of evidence created new obstacles even as it struck down the old. In the very years in which the common law of evidence swept out the witness disqualification rules, new doctrines developed that excluded particular kinds of testimony rather than particular classes of witnesses. ${ }^{335}$ In particular, the hearsay rule developed to exclude out-of-court statements by persons not testifying at trial. ${ }^{336}$

Of particular interest is the interaction of the hearsay rule and its exceptions with the corporate or organizational context of personal in-

326 See An Act to Prevent Usury, ch. 430, I837 N.Y. Laws 486.

327 In the $1830 \mathrm{os}$, criticism of the disqualification rules mounted. In particular, law reformers drew on a new legal technology - cross-examination - to sort out truths and falsehoods in oral testimony. The disqualification rule's guarantee of disinterestedness thus became considerably less important to common law factfinding. See John Fabian Witt, Making the Fifth: The Constitutionalization of American Self-Incrimination Doctrine, I79I-I903, 77 TEX. L. REV. 825, 864-66 (1999).

32822 Mich. Rev. Stat., ch. I02, § 99 (1846).

329 Conn. Rev. Stat., tit. I, ch. x, § I4 I (I849).

330 First RePort of the COMMISSIONERS ON PRACTICE AND Pleadings: Code OF PROCEDURE § 35 I, at 246 (Albany, Charles Van Benthuysen I848).

331 See id. § 344, at 242.

332 George Fisher, The Jury's Rise as Lie Detector, I07 YALE L.J. 575, 7 10 (1997); Witt, supra note 327 , at $854-58$.

333 NELSON, supra note 318 , at 157.

334 See Fisher, supra note 332, at 673-74, 709-I I.

335 See C.J.W. Allen, THE LAW OF EvidENCE IN Victorian ENGland I4 (I997) (arguing that the "main problem" faced by analysts of nineteenth-century evidence law is accounting for the shift from "the old exclusionary rules about competency of witnesses" to the "exclusionary, rulebased system that began to govern testimony given in court"); see also Langbein, supra note 318 , at I I94, I 20 I (concluding that the hearsay rule and the modern exclusionary doctrines of the law of evidence are products of the early nineteenth century).

336 See, e.g., I FRANK S. RICE, THE GENERAL PRINCIPLES Of THE LAW OF EVIDENCE $§ 2$ I I , at 367 (Rochester, Lawyers' Co-Operative Publishing Co. I892). 
jury litigation. One of the long-established exceptions to the hearsay rule is that the admissions of a party may be offered as evidence against her. ${ }^{337}$ Simon Greenleaf's early American evidence treatise, for example, observed that "the declarations of a party to the record" were, "as against such party, admissible in evidence." 338 When a railroad company or a corporate employer was the defendant in an action for personal injury, however, the disembodied nature of the defendant required that the plaintiff call not the party itself but one of its agents. How, after all, could a corporation testify except through its agents?

Today, the modern rule for agent admissions establishes that a statement is not hearsay if it is "a statement by the party's agent or servant concerning a matter within the scope of the agency or employment." 339 Courts interpret this rule expansively to encompass all statements "naturally made in the course of the agency," including post-accident statements by agents involved in the accident. ${ }^{340}$

In contrast, the nineteenth-century party admission rule sharply limited the admission of agents' statements as evidence against a corporate principal. The nineteenth-century rule was closely linked to the now-antiquated evidence doctrine of the "res gestae": statements "contemporaneous with" the event in question so that they were said to form "one transaction" 341 with (or "spring out of" ${ }^{342}$ ) the event. Thus, the nineteenth-century party admission rule allowed the admission of only the statements that an agent made "at the time of, and in relation to, some act then being performed in the scope of the agent's duty"343 - in other words, statements "made at the same time, and constituting part of the res gestae." 344

The res gestae rule had its origins in commercial contract cases in the early part of the century. ${ }^{345}$ But by the last thirty years of the

337 See, e.g., MCCORMICK ON EvideNCE $\S 262$, at 774 (John William Strong ed., 4th ed. I992).

338 Simon GREENLEAF, A TREATISE ON THE LAW OF EVIDENCE § I 7 I, at 225 (Boston, Little \& Brown, 5th ed. I850).

339 FED. R. EVID. 80I(d)(2)(D); see also 4 JOHN HENRY Wigmore, EVIDENCE IN TRIALS AT COMMON LAW § 1078, at I62 (James H. Chadbourn ed., I976).

3404 WIGMORE, supra note 339, § I078, at I66 n.2 (quoting Slifka v. Johnson, I6I F.2d 467, 469 (2d Cir. 1947)); see, e.g., Koninklijke Luchtvaart Maatschappij N.V. KLM Royal Dutch Airlines Holland v. Tuller, 292 F.2d 775, $782-85$ (D.C. Cir. I96I).

341 I RICE, supra note $336, \S 2$ I 2 , at 375.

342 Gandy v. Humphries, 35 Ala. 61 7, 624 (1860).

343 MCCORMICK ON EVIDENCE, supra note $337, \S 259$, at 454.

344 Simon GREenleaf, A TREATISE ON THE LAW OF EVIDENCE $\S$ i I 3 , at 145-46 (Isaac E. Redfield ed., I 2 th ed., Boston, Little \& Brown I866). "[W] matter in question has ceased," however, "the principal can no longer be affected by his declarations, they being mere hearsay." Id. $\S$ I I 3 , at 149 .

345 See, e.g., Lundie v. Cosper, 20 Ala. I23, I 26 (1852); Williams v. Kelsey, 6 Ga. 365 (1849); Waterman v. Peet, II Ill. 648, 649 (I850); Snow v. Warner, 5 I Mass. (Io Met.) I32, I37 (I845); Salem India Rubber Co. v. Adams, 40 Mass. (23 Pick.) 256, 265 (I839); Richardson \& Price v. Cato, 29 Tenn. (Io Hum.) I38, I40 (I849). 
nineteenth century, accident cases formed the most important share of agent-admission cases; indeed, in the I860s streetcar and railroad injury lawsuits became the paradigmatic res gestae cases. ${ }^{346}$ In the 1866 edition of Greenleaf's treatise, for example, the editor's discussion of the doctrine centered on the case of a post-accident admission of negligence by a streetcar driver. Such an admission was not admissible against the streetcar company, Isaac Redfield explained, "being made after the injury was inflicted." ${ }^{347}$ In subsequent decades, an outpouring of cases in the reporters testified to the power of the res gestae rule to exclude statements that plaintiffs sought to introduce in personal injury litigation. The pre-accident statements of a railroad company roadmaster as to the incompetence of an injured worker's fellow employee were excluded as not being part of the res gestae. ${ }^{348}$ Similarly, the declarations of a conductor as to the poor condition of a railroad track made a "moment before the accident" were "inadmissible" as not part of the res gestae. ${ }^{349}$ Post-accident statements, though made "within an hour, describing the cause of the accident," were not competent against the principal, ${ }^{350}$ nor were statements made ten to thirty minutes after an accident as to the excessive speed of the railroad

346 A collection of representative cases includes: Lincoln Coal Mining Co. v. McNally, I5 Ill. App. I8I, I84-85 (I884) (holding declarations of defendant coal mine's servants inadmissible when not forming part of the res gestae of the accident); Patterson v. Wabash, St. Louis $\mathcal{E}$ Pac. Ry. Co., I9 N.W. 76I, 765-66 (Mich. I884) (holding the post-accident statement of railroad company servant inadmissible); Forsee v. Ala. Great S. R.R. Co., 63 Miss. 66, 72 (1885) (holding the postaccident declaration of a railroad ticket agent inadmissible); Meyer $v$. Va. E Truckee R.R. Co., I6 Nev. 34 I, 344-46 (I88I) (finding post-fire statements of the defendant's agent inadmissible when not part of the res gestae); Erie \& W. Va. R.R. Co. v. Smith, I7 A. 443, 445-447, I 25 Pa. 259,264 (I889) (deeming the post-accident declaration of a defendant railroad corporation's servants as to character of engine inadmissible). An exception to the rule existed for statements tending to prove that a corporation had notice of a particular employee's incompetence or a particular piece of machinery's dangerousness. See, e.g., Chapman v. Erie Ry. Co., 55 N.Y. 579, 584-85 (I874) (admitting the pre-accident statements of a supervisor tending to show that the principal knew of his fellow servant's incompetence). Accident cases continue today to pose some of the most difficult cases for the party admission doctrine. 4 WIGMORE, supra note 339 , $\S$ I078, at I 66 ("The most difficult field in the application of this principle is that of tortious liability.").

347 GREENLEAF, supra note $344, \S$ I I 3 , at I 34 ; see also I RICE, supra note 336 , § 230 , at 449 (citing railroad cases).

348 McDermott v. Hannibal \& St. Joseph R.R. Co., 73 Mo. 5 I6, 5 I8-I9 (I88I).

349 The Res Gestae of an Accident, 4 WKLY. L. BULL. 872, 872 (1878); see also The Res Gestae of an Accident, Io CENT. L.J. 23, 23 (1880) (citing Mobile \& Montgomery R.R. Co. v. Ashcraft, 48 Ala. I5 (I872)); id. (statement of stage driver that coach was overloaded inadmissible as evidence for the plaintiff) (citing Maury v. Talmadge, I6 F. Cas. I I82, I I84 (D. Ohio I840) (No. 9315)); id. (declarations of boat pilot) (citing Ready v. Steamboat Highland Mary, 20 Mo. 264 (I855)).

350 The Res Gestae of an Accident, supra note 349, at 24 (1880); Case Note, 4 I CENT. L.J. 397, 397 (1895) (citing St. Louis Iron Mountain \& S. Ry. Co. v. Kelley, 3 I S.W. 884, 884-85 (Ark. I895)); see also Evidence, 40 CENT. L.J. I66, I66-67 (1895) (discussing Barker v. St. Louis Iron Mountain E Southern Railway Co., 28 S.W. 866, 866-67, I26 Mo. I43 (Mo. I894) (holding a conductor's declaration made eight to ten minutes after accident not admissible as not within the res gestae)); The Res Gestae of an Accident, supra note 349, at 872 (1878). 
car. $^{351}$ Even written post-accident reports by agents to their principals were held to be inadmissible against the principal as outside of the res gestae unless they "had been promulgated by the company as official documents adopted by and proceeding from it." 352

The res gestae rule also operated to exclude a wide array of statements that plaintiffs sought to admit under other exceptions to the hearsay rule. In one particularly brutal case, the dying declaration of the plaintiff's husband was held inadmissible. While still lying on the tracks, after the wheels of a railroad car had been removed from his body, the deceased had managed to say that the "handhold" had let him down. But the Alabama Supreme Court explained that this statement "was no part of the main fact" as it had been "made after the car was removed from over the body." 353 Similarly, though midcentury courts permitted the introduction of "all declarations of pain, suffering, ... [and] expressions of pain and distress at the time of such suffering," 354 toward the end of the century courts increasingly applied the res gestae rule to exclude contemporaneous expressions of pain and suffering. ${ }^{355}$

4. The Rise of Personal Injury Litigation and the Personal Injury Lawyer. - Restrictive common law tort doctrines and inflexible evidentiary rules, however, could not stanch the outpouring of new tort litigation in the 1860 s and I870s. The number of accident cases and the number of lawyers both shot up after 1870. At least part of the reason that accident litigation had been slow to come to mining and textile regions was the relative scarcity of lawyers in such isolated areas. In urban areas after 1860 , however, there was no dearth of attorneys. From the end of the Civil War to the turn of the century, a boom in the number of lawyers - and especially in the number of

351 Vicksburg \& Miss. R.R. Co. v. O'Brien, I 9 U.S. 99 (I886).

352 Notes of Recent Decisions, 30 CENT. L.J. 2 , 3 (1890) (citing Carroll v. E. Tenn., Va. \& Ga. Ry. Co., Io S.E. I 63 (Ga. I889)). The mid- and late nineteenth-century doctrine appears to have limited the scope of agents' admissions to "spontaneous exclamation[s]," which constitute a specific hearsay exemption today. See Note, 40 CENT. L.J. I67, I67-68 (I894) ("If . . the court is satisfied that the agent, without time to premeditate, expressed truly and spontaneously his thoughts in regard to a fact within his knowledge and in issue ... the evidence would be admissible."); see also 6 WIGMORE, supra note 339 , $\$ \S 1756 \mathrm{a}-1757$, at $234-37$ (discussing confusion in the early case law between res gestae and spontaneous exclamations).

353 Res Gestae - Admissibility Of Declarations as a Part of - Railroad Accidents, 36 CENT. L.J. I70, I 72 (I893) (citing Louisville \& Nashville R.R. Co. v. Pearson, I2 So. I76, I79 (Ala. I893)).

354 I RICE, supra note $336, \S 2$ I 2 , at 377 (citing cases).

355 See id. at 384 ("Apparent abuses resulting from receiving descriptive declarations of pain in negligence cases, has led to a reconsideration of the rule; and the better opinion now is that a party seeking to recover damages on account of his own suffering cannot give in evidence, in his own behalf, his own descriptive declarations of suffering, as distinguished from apparently spontaneous manifestations of the distress."). 
first- and second-generation immigrant lawyers - occurred alongside even more dramatic growth in the number of personal injury lawsuits.

Even as late as the mid-nineteenth century, remarkably few Americans sued for personal injuries. Randolph Bergstrom found that in New York City in 1870 , just $0.6 \%$ of cases filed in state court were accident or tort cases. ${ }^{356}$ Only $40.7 \%$ of these were for personal injuries, constituting a total of thirteen personal injury suits for the entire year, some thirteen years after the abolition of the party disqualification rule in New York. ${ }^{357}$ By I 890, however, the number of accident suits being litigated in New York courts had grown almost eight-fold, and by rgro that number had grown again by more than a factor of four. ${ }^{358}$ Among contested cases, the rise in the number of personal injury suits was almost as dramatic. Whereas in 1870 tort cases of all kinds represented only $4.2 \%$ of the New York City trial court contested caseload, by I 9 Io they made up $40.9 \%$ of that caseload, just under a ten-fold increase. ${ }^{359}$ Similarly, as Robert Silverman has found, in Boston as late as 1880 there were no more than "a dozen or so suits . . filed in superior court alleging damage caused by negligent operation of a horsecar." 360 A mere twenty years later, however, there were over 800 personal injury cases involving streetcars in superior court, and 600 more in the municipal court. ${ }^{361}$

These developments in the law of personal injury hardly went unnoticed. E. Parmalee Prentice, writing in the North American Review, found a $800 \%$ increase in the number of personal injury suits pending in the Cook County, Illinois courts between I875 and 1896.362 Eli Shelby Hammond complained in the Yale Law Journal that "slight wrongs or injuries that ordinarily were never noticed hitherto," were increasingly being "made the foundation for building up by perjury ... claims for enormous damages."363 By I907, Elon R. Brown of the New York State Bar Association explained that "[n]egligence cases are

356 Bergstrom analyzed the case records from the state supreme court, which was (as it is today) the trial court of general jurisdiction. See BERGSTROM, supra note 58, at 20 tbl.4.

357 Id.

$358 I d$.

359 Id. at I 7 tbl.2.

360 Robert A. Silverman, LAW AND URBAN GRowTH: CiVIL Litigation IN THE BostoN TRIAL COURTS, I880-I900, at I05 (I98I).

361 Id.; see also George Fisher, Plea Bargaining's Triumph, I09 YALE L.J. 857, 995-I00I (2000) (discussing the rise in civil litigation in the nineteenth century).

362 E. Parmalee Prentice, The Speculation in Damage Claims for Personal Injuries, I64 N. AM.

REV. I99, I99 (I897).

363 Eli Shelby Hammond, Personal Injury Litigation, 6 YALE L.J. 328, 332 (I897). 
blocking our calendars with a mass of litigation so great as to impede administration in all other branches of law." 364

At the same time that the number of accident cases was growing sharply, the number of lawyers was also increasing. United States census records provide a wide-angle view of the profession in the period from 1870 to I910.365 In the United States as a whole, the number of lawyers jumped by almost 150\% between 1870 and 1900, and the number of individuals in the paid workforce per lawyer decreased from 307 to 256 . At the state level, the number of lawyers in New York State increased by an average of $37 \%$ each decade between I 870 and 1900 . The number of persons in paid occupations for every lawyer in the state decreased by approximately one fifth over the course of the three decades, from 252 to 203 . Breakdowns of these numbers by national origin are slightly more difficult as a result of changing census categories, but it appears that the main growth area in the legal profession in these years was among the children of immigrants: in the ten years between 1890 and 1900 , the number of white native-born lawyers with parents of foreign or mixed birth in New York State grew by $75 \%$, two and a half times the rate of growth among lawyers overall. Nationally, the number of white native-born lawyers with parents of foreign or mixed birth grew by $80 \%$ in the same decade, almost three times the rate of growth among lawyers generally.

364 Elon R. Brown, Some Faults of Legal Administration, in N.Y. STATE BAR ASS'N,

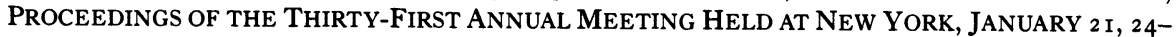
25, I 908 , at I 36,142 (I908).

365 A change in I9IO in the way the category of "lawyer" was defined makes comparisons between pre- and post-rgio census information problematic. For statistical treatment of the legal profession, see RICHARD L. ABEL, AMERICAN LAWYERS 249-318 (I 989); Terence C. Halliday, Six Score Years and Ten: Demographic Transitions in the American Legal Profession, 1850-1980, 20 LAW \& SOC'Y REV. 53 (1986). The data presented here is compiled from the published reports of the U.S. Census Bureau. 


\section{Table i. The Growth of the Legal Profession: LAWYERS IN NEW YORK STATE, I870-I930*}

\begin{tabular}{|l|l|l|l|l|l|l|}
\hline Year & Lawyers & $\begin{array}{l}\text { Persons in } \\
\text { Paid Occu- } \\
\text { pations }\end{array}$ & $\begin{array}{l}\text { Pct. Growth } \\
\text { in Lawyers }\end{array}$ & $\begin{array}{l}\text { Persons in } \\
\text { All Paid } \\
\text { Occupa- } \\
\text { tions Per } \\
\text { Lawyer }\end{array}$ & $\begin{array}{l}\text { White Na- } \\
\text { tive-Born } \\
\text { Lawyers with } \\
\text { Foreign or } \\
\text { Mixed-Birth } \\
\text { Parents }\end{array}$ & $\begin{array}{l}\text { Pct. Growth in } \\
\text { White Native- } \\
\text { Born Lawyers } \\
\text { with Foreign or } \\
\text { Mixed-Birth } \\
\text { Parents }\end{array}$ \\
\hline $\mathrm{I} 870$ & 5,913 & $\mathrm{I}, 49 \mathrm{I}, 018$ & - & 252 & - & - \\
\hline $\mathrm{I} 880$ & 9,459 & $\mathrm{I}, 884,645$ & $60 \%$ & $\mathrm{I} 99$ & - & - \\
\hline $\mathrm{I} 890$ & $\mathrm{II}, 194$ & $2,435,725$ & $\mathrm{I} \%$ & $2 \mathrm{I} 8$ & 2,299 & - \\
\hline $\mathrm{I} 900$ & $\mathrm{I} 4,759$ & $2,996,474$ & $32 \%$ & 203 & $4,09 \mathrm{I}$ & $75 \%$ \\
\hline $\mathrm{I} 910^{366}$ & $\mathrm{I} 7,27 \mathrm{I}$ & $4,003,844$ & - & - & 5,310 & $32 \%$ \\
\hline $\mathrm{I} 920$ & $\mathrm{I} 8, \mathrm{I} 29$ & $3,367,909$ & $5 \%$ & $\mathrm{I} 86$ & 5,999 & $\mathrm{I} \%$ \\
\hline $\mathrm{I} 930$ & 27,593 & $5,523,337$ & $52 \%$ & 200 & - & - \\
\hline
\end{tabular}

* i Dep't of the INTERior, Census OfFice, The Statistics of the Population OF THE UNITED STATES . . COMPILED FROM THE ORIGINAL RETURNS OF THE NINTH Census (1870) (Washington, D.C., Gov't Printing Office I872); I DEP'T OF THE INTERIOR, Census Office, The Statistics of the Population of The United States at the TENTh Census (I880) (Washington, D.C., Gov't Printing Office I880); I DEP'T OF THE InTERior, Census OfFice, The Statistics of THE POPUlation of THE UNited States at The Eleventh Census (1890) (Washington, D.C., Gov't Printing Office I890); I DEP'T OF COMMERCE AND LABOR, BUREAU OF THE CENSUS, SPECIAL REPORTS: OCCUPATIONS OF THE TWELFTH CENSUS (I904); DEP'T OF COMMERCE, BUREAU OF THE Census, Population igio: ThiRTeEnth Census of the United States Taken in THE Year Igio, Volume IV: OCCUPATION STATISTICS (I9I4); DeP'T OF COMMERCE, Bureau of the Census, Population i920: Fourteenth Census of the United STATES TAKEN IN THE YeAR I920, VOLUME IV: OCCUPATIONS (I923); U.S. DEP'T OF COMMERCE, BUREAU OF THE CENSUS, FifTeENTH CENSUS OF THE UNITEd STATES: ig3o Population, Volume IV: OCCupations, by STATES (I933); U.S. DeP'T OF COMMERCE, BUREAU OF THE CeNSUS, FifTEenth CENSUS OF THE UNited STATES: i930 Population, Volume V: General Report ON OCCUPATIONS (I933).

366 The definition of "lawyer" was amended in I9I0 to remove semiprofessionals, namely, notaries, abstractors, and justices of the peace. DEP'T OF COMMERCE, BUREAU OF THE CENSUS,

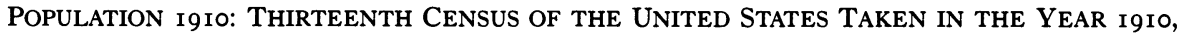
VOLUME IV: OCCUPATION STATISTICS (Gov't Printing Office I9I4). 


\section{Table 2. The Growth of the Legal Profession: LAWYERS IN T'HE UNITED STATES*}

\begin{tabular}{|c|c|c|c|c|c|c|c|}
\hline Year & $\begin{array}{l}\text { All Paid } \\
\text { Occupations }\end{array}$ & Lawyers & $\begin{array}{l}\text { Pct. } \\
\text { Growth } \\
\text { in the } \\
\text { Num- } \\
\text { ber of } \\
\text { Law- } \\
\text { yers }\end{array}$ & $\begin{array}{l}\text { Number of } \\
\text { People in } \\
\text { the Paid } \\
\text { Workforce } \\
\text { Per Law- } \\
\text { yer }\end{array}$ & $\begin{array}{l}\text { White } \\
\text { Native- } \\
\text { Born } \\
\text { Lawyers } \\
\text { with For- } \\
\text { eign or } \\
\text { Mixed- } \\
\text { Birth } \\
\text { Parents }\end{array}$ & $\begin{array}{l}\text { Pct. } \\
\text { Growth in } \\
\text { the Num- } \\
\text { ber of } \\
\text { White } \\
\text { Native- } \\
\text { Born } \\
\text { Lawyers } \\
\text { with For- } \\
\text { eign or } \\
\text { Mixed- } \\
\text { Birth Par- } \\
\text { ents } \\
\end{array}$ & $\begin{array}{l}\text { Number of } \\
\text { White Na- } \\
\text { tive-Born } \\
\text { Children of } \\
\text { Foreign or } \\
\text { Mixed-Birth } \\
\text { Parents in the } \\
\text { Paid } \\
\text { Workforce } \\
\text { per Similarly } \\
\text { Situated } \\
\text { Lawyer }\end{array}$ \\
\hline 1870 & $\mathrm{I} 2,505,923$ & 40,736 & - & 307 & - & - & - \\
\hline 1880 & $17,392,099$ & 64,137 & $57 \%$ & $27 \mathrm{I}$ & - & - & - \\
\hline 1890 & $23,318,183$ & 89,630 & $40 \%$ & 260 & II, 034 & $3,542,408$ & 321 \\
\hline 1900 & $29,287,070$ & I I 4,460 & $28 \%$ & 256 & 19,900 & - & 266 \\
\hline I910 & $38,167,336$ & II 4,704 & - & - & $2 \mathrm{I}, 8 \mathrm{I} 4$ & - & - \\
\hline 1920 & $4 \mathrm{I}, 6 \mathrm{I} 4,248$ & 122,519 & $31 \%$ & 340 & 27,288 & - & 306 \\
\hline 1930 & 48,829920 & 160,605 & - & 304 & - & - & - \\
\hline
\end{tabular}

* i Dep'T of the INTERIOR, Census OfFice, The Statistics of the PopUlation OF THE UNITED STATES . . COMPILED FROM THE ORIGINAL RETURNS OF THE NINTH Census (I870) (Washington, D.C., Gov't Printing Office I872); I DEP'T OF THE INTERIOR, Census OfFice, The Statistics of the Population of the United States at the Tenth Census (i880) (Washington, D.C., Gov't Printing Office I880); I DeP'T OF THE INTERIOR, Census OfFice, The STATISTICS OF THE POPUlation OF THE UNited States at The Eleventh Census (I890) (Washington, D.C., Gov't Printing Office I890); I DEP'T OF COMMERCE AND LABOR, BUREAU OF THE CENSUS, SPECIAL REPORTS: OCCUPATIONS OF THE TWELFTH CENSUS (I904); DEP'T OF COMMERCE, BUREAU OF THE Census, Population igio: THIRTEenth Census of THE UNited STATES Taken in THE YeAR Igio, Volume IV: OCCUPATION STATISTICS (I9I4); DeP'T OF COMMERCE, Bureau of the Census, Population ig20: Fourteenth Census of the United STATES TAKEN IN THE YeAR I920, VOLUME IV: OCCUPATIONS (I923); U.S. DEP'T OF Commerce, Bureau of the Census, Fifteenth Census of the United States: I930 POPUlATION, VOluME V: GENERAL REPORT ON OCCUPATIONS (I933).

Similar patterns characterized the legal profession in New York State's major cities. In Manhattan, the growth rate in lawyers as compared to the paid workforce considerably exceeded the state average. Between 1870 and 1900 , the number of persons in paid occupations for every one lawyer decreased by $36 \%$, from 273 to $174 .{ }^{367}$ Once

367 Department of the Interior, Census OfFice, The Statistics of the Population OF THE UNITEd STATES ... COMPILED FROM THE ORIGINAL RETURNS OF THE NINTH CENSUS (1870) (Washington, D.C., Gov't Printing Office I872); I DEP'T OF THE INTERIOR, CENSUS OfFice, The Statistics of the Population of the United States at THE Tenth Census (I880) (Washington, D.C., Gov't Printing Office I880); I DEP'T OF THE INTERIOR, CENSUS Office, The Statistics of the Population of the United States at THE Eleventh 
again, white children of immigrants represented the major growth category, with the number of lawyers in this class growing by $85 \%$ between I 890 and I 900 , compared to a $49 \%$ growth rate for lawyers generally. ${ }^{368}$ Unlike Manhattan, Buffalo nearly matched the state average in the per capita growth in lawyers. ${ }^{369}$ In Buffalo, however, the growth in the number of lawyers who were the white children of immigrants was an astounding $170 \%$ from 1890 to $1900 .{ }^{370}$ Some cities lagged behind the state's average growth in the number of lawyers per capita. Albany, Syracuse, and Troy experienced smaller than average growth in the number of lawyers per person in paid occupations; ${ }^{371}$ Brooklyn and Rochester experienced small decreases in the number of lawyers per person. ${ }^{372}$ Even in these cities, however, the number of native-born white lawyers with parents of foreign or mixed birth grew disproportionately as compared to lawyers generally. ${ }^{373}$

Increased competition for business among lawyers appears to have pushed the newcomers at the bar - and particularly the children of immigrants, who lacked connections to steadier or more lucrative work - to generate new kinds of business. ${ }^{374}$ Young lawyers training to take on personal injury cases were instructed in no uncertain terms that although there were clear limits on soliciting business from accident victims, actively soliciting cases was an indispensable part of the practitioner's livelihood. At Northwestern University Law School's Course in Legal Tactics, for example, Andrew Hirschl of the Chicago Bar advised students going into plaintiff-side personal injury law to distinguish between the "improper[]" solicitation of business and solicitation of business more generally. "Let me tell you frankly, gentlemen," he warned:

[I]f you don't solicit them you won't get them. You might as well make up your minds to it. I have watched this thing for over thirty-three years, at the bar here and elsewhere. If you don't solicit those cases you won't get them.... [T] them you won't get them. That is plain.... Now, those men are after

Census (I890) (Washington, D.C., Gov't Printing Office I890); I DEP'T OF COMMERCE AND LABOR, BUREAU OF THE CENSUS, SPECIAL REPORTS: OCCUPATIONS OF THE TWELFTH CENSUS (1904). The extremely high growth rate of lawyers in Manhattan suggests a qualification of Bergstrom's claim that "after I 880 the population grew at an even faster pace than the number of lawyers." BERGSTROM, supra note 58, at 88.

368 See Census Reports cited in Tables, supra pp. 76I-62.

369 Id.

370 Id.

371 Id.

372 Id.

373 Id.

374 Immigrant lawyers may also have sympathized more strongly with working-class accident victims; at the very least, they were more likely than elite lawyers to have contacts in the communities in which many accident plaintiffs lived. 
these cases. And they will get them. If you are willing to sit in your office, then they will get the cases. ${ }^{375}$

Following Hirschl's advice, and indeed going considerably further, the plaintiffs' personal injury bar created intricate networks of "runners," including members of the police and railroad workforces, who received a percentage of the lawyer's take from each case. ${ }^{376}$ Others among the plaintiffs' bar - though probably fewer than their opponents in the defense bar imagined - moved into the shady world of claims fraud, fabricating personal injury claims to bring suits against streetcar companies and other corporate defendants. ${ }^{377}$ Moreover, at least some plaintiffs' lawyers engaged in questionable settlement practices. Upstate New York lawyer Arthur Clark, for example, sold out more than 300 clients in a brazen deal with the Central New York Telephone \& Telegraph Company. ${ }^{378}$

The defense bar developed similarly dubious strategies to obstruct personal injury litigation. On one level, this meant little more than ingenious exploitation of the complex procedural rules and overlapping jurisdictional rules of the federal and state court systems to stall cases on ancillary issues. ${ }^{379}$ At another level, however, it meant stooping to depths reached only by the most unscrupulous members of the plaintiffs' bar. Railroads paid off employees to make themselves unavailable to testify on an injured co-worker's behalf. ${ }^{380}$ Insurance agents and claims adjusters approached still-dazed victims seeking to execute releases for paltry sums. ${ }^{381}$ Corporate defense lawyers struck corrupt bargains with plaintiffs' counsel in return for a steady flow of defense work. $^{382}$

It is difficult to tell from any of this evidence, of course, whether the rise of injury claims resulted from the increase in the number of lawyers or vice versa. It may not matter, however, whether lawyers or

375 Andrew J. Hirschl, The Plaintiff's Standpoint, I ILL. L. REV. I6, I 7 , I9 (1906).

376 See, e.g., In re Clark, 77 N.E. I, 5-6 (N.Y. I 906) (disbarring an attorney who, among other things, sold the claims of his own clients for \$25 each); In re Newell, I 74 A.D. 94, 98-99 (N.Y. App. Div. I9I6) (per curiam) (disbarring an attorney for paying an employee of the New York Central Railroad Company to monitor the company's telegraphic communications and notify him of accidents - and thus potential clients).

377 See the interesting but sensationalist and decidedly one-sided KEN DORNSTEIN, ACCIDENTALly, ON PURPOSE: THE MAKING OF A PERSONAL INJURY UNDERWORLD IN AMERICA 53-I9I (I997).

378 Clark, 77 N.E. at 5.

379 See BERGSTROM, supra note 58, at IOI-I 2; see generally EDWARD A. PURCELL, JR., LITIGATION AND INEQUALITY (I992).

380 BERGSTROM, supra note 58, at 99-100.

381 See the accounts of personal injury practice in Edward A. Purcell, The Action Was Outside the Courts: Consumer Injuries and the Uses of Contract in the U.S., 1875-1945, in PRIVATE LAW AND SOCIAL INEQUALITY IN THE INDUSTRIAL AGE 505, 5 I 3-2 I (Willibald Steinmetz ed., 2000).

382 See, e.g., SILVERMAN, supra note 360, at 99-100. 
claims came first in time. The two trends no doubt at once responded to, interacted with, and accelerated one another. What evidence exists makes it fairly clear that many suits were brought that would not otherwise have been filed but for the encouragement of lawyers seeking contingent fees. ${ }^{383}$ Even when lawyers did not actively seek out cases, their increased presence in a particular city may well have heightened the probability that accident victims would approach them. And such increased demand for legal services, in turn, may have encouraged undecided fence-sitters to train for the profession.

In any event, from the perspective of the elite of the bar the boom in personal injury suits threatened the reputation of the profession and even, some suggested, the rule of law itself. ${ }^{384}$ It was the plaintiffs' bar that came in for the most criticism. "Barratrous speculations," the "communistic tendencies of the present time," and the lure of "enormous verdicts," it was said, had led to such practices as advertising and solicitation "at the expense of all manly and professional dignity." 385 Personal injury litigation was said to be "marked by a lower tone of professional ethics at the Bar and by a greater absence of abstract justice on the Bench than any other class of litigation."386 According to Irving Vann of the New York Court of Appeals in his famous commencement address at the Albany Law School, personal injury lawyers on the plaintiffs' side were practicing massive fraud by encouraging perjurious testimony from so-called expert witnesses in order to reap substantial contingent fees, thereby "rob[bing] corporations of thousands of dollars every year." 387 According to Cooley, the contingent fee disrupted the lawyer's professional obligations to court and client alike. It tempted lawyers to "deal deceitfully" with potential clients by exaggerating the difficulty of cases in order to extract higher fee percentages, and it placed the lawyer's selfish interest in the outcome of the case over his obligations to the "just administration of the

383 See, e.g., In re O'Neill, I 7 I N.Y.S. 5 I4, 5 I5 (App. Div. I9I8) (discussing allegations that an attorney used runners to generate accident claims that otherwise appeared unlikely to have been brought).

384 See, e.g., Hammond, supra note 363 , at 332 ("The sharp practices of two professionals, legal and medical, are called in to aid the money-raid upon the unfortunate tortfeasor."); Prentice, supra note 362 , at 204-08 (blaming the increase in injury suits on the development of professional speculation in personal injury litigation); see also To Establish Rules of Professional Ethics: $A$ Proper Function of the Association, 3 N.Y. ST. B. ASS'N REP. 74, 78-79 (1880) (observing that many lawyers in the Association viewed contingent fees as "disreputable, unworthy, demoralizing and tending to degrade the profession and impair the administration of justice").

385 To Establish Rules of Professional Ethics, supra note 384, at 78-79.

386 Brown, supra note 364 , at 142 .

387 IRVING G. VANN, CONTINGENT FEes: AdDRESS IN HUBbaRd CoJRSE ON LEGAL ETHICS DELIVERED AT COMMENCEMENT OF ALBANY LAW SCHOOL IO-I2 (I905) (internal quotation marks omitted). 
law." 388 Moreover, the contingent fee arrangement led plaintiffs' lawyers to file frivolous suits against corporate defendants in the hopes of exploiting the "effect of appeals to passion or prejudice" in the jury. ${ }^{389}$

Cooley, then, saw in the contingent fee and the rising tide of accident litigation threats to the abstract reason and cohesiveness of classical legal thought. He was right, of course. Little in the messy, murky underworld of personal injury litigation corresponded to the airy propositions of Cooley's torts treatise. Tort liability in the real world, it seemed, turned not on classical liberal principles, but on the questionable tactics of runners and insurance adjusters, the common law evidentiary system, and the persistence of employer power over injured employees. ${ }^{390}$

5. The Rise of Faultless Injuries and the Compensation Crisis. Another quickly developing trend was even more threatening to the doctrinal edifice of classical tort law. It was becoming apparent to many that an increasing number of the victims of personal injuries, especially victims of injuries suffered in the workplace, were themselves faultless. Injuries, it seemed, were the inevitable result of modern methods of industrial production. Such unavoidable accidents raised precisely the problem that lay at the core of classical tort law: the faultless (or "accidental," as Holmes would have it) victim of nonnegligent injury.

As late as the early I880s, students of American industrial accidents believed that accidents were almost always the result of someone's fault. "Every death upon a railroad," explained Carroll Wright in I 883 , "like every death by violence, is the result of somebody's negligence or wilfulness." ${ }^{391}$ By the turn of the century, however, it seemed increasingly unlikely in many instances that accidents could be traced to any human fault. The New York Bureau of Labor Statistics claimed that "in modern industry," with its "extremely complicated machinery," it was "impossible to locate the responsibility" in work accident cases. ${ }^{392}$ In Maryland in I902, the legislature announced that in "perilous occupations ... unavoidable or trade risk is responsible for at least ninety-five per cent" of fatal accidents. ${ }^{393}$ In Minnesota, the Bureau of Labor reported that most work accidents were due not to employer or employee negligence but to the unavoidable "hazards of the

388 The Contingent Fee Business, 24 ALB. L.J. 24, 25-26 (188I).

389 Id. at 26.

390 Fishback and Kantor's statistical studies of late nineteenth- and early twentieth-century tort law support Cooley's suspicions: common law doctrines appear to have had some influence on the "probability and level of accident payments, but they were clearly not the only influence and sometimes not even the dominant influence." FISHBACK \& KANTOR, supra note 6, at 45 .

391 I 4 ANN. Rep. MASS. BUREAU OF Stat. Of LAB. pt. I, at 68 (Boston, Wright \& Potter I883).

392 I 7 ANN. REP. N.Y. BUREAU OF LAB. STAT. 559 (I900).

393 I902 Md. Laws, ch. 4I 2. 
industry." ${ }^{394}$ Reports on the accident problem in Iowa observed that the toll of work accidents was "in great part[] unavoidable" and that even "when all possible precautions have been taken, modern industry will continue to exact a fearful toll of life and limb."395 Crystal Eastman's widely influential study of work accidents in Pittsburgh made much the same point: in a substantial number of work accident fatalities, Eastman contended, "no one is to be blamed."396

State bar associations, too, came to see industrial accidents as resulting not from the fault of particular parties but from inevitable risks. "[I]n many, if not all, lines of employment," observed one Ohio Bar Association report, "there is an element of inherent danger which, in measuring employees' injuries, is quite as important as the element of negligence." 397 No matter how careful the employee and employer were, explained another report to the Ohio Bar Association a year later, more than half of work accidents were "due to the natural hazards or dangers of the business." 398

Indeed, the rise of faultless injuries precipitated a compensation crisis in the law of accidents. In recent years, legal historians have disagreed strongly over the relative stinginess or generosity of common

394 Don D. Lescohier, Industrial Accidents and Employers' Liability in Minnesota, in PART II OF THE TWELFTH BIENNIAL REPORT OF THE BUREAU OF LABOR, INDUSTRIES AND COMMERCE OF THE STATE OF MINNESOTA I909-19IO, at I56 (I9IO).

395 E.H. DOWNEY, HISTORY OF WORK ACCIDENT INDEMNITY IN IOWA 2 (I9I2) ("Doubtless the number of work accidents may be considerably reduced in the United States, as it has been reduced in Europe, by preventative measures... Scientific accident prevention in Germany has produced a lower accident rate and a much lower rate of fatal accidents than obtains in the United States, but it has left the total casualty list of industry deplorably large. Indeed, the number of work injuries in Germany, as elsewhere, is increasing, both absolutely and relatively to the numbers employed, as industrial development goes forward." (internal footnotes omitted)).

396 EASTMAN, supra note 164 , at 86 . It is worth noting that the argument here reverses the standard account of the shift in attribution of blame in the late nineteenth century. Lawrence Friedman argues - drawing on Samuel Clemens's wonderful story of a steamboat accident in the novel The Gilded Age - that the mid-nineteenth century was a period in which the law held "NOBODY TO BLAME" for accidents causing injury and death. FRIEDMAN, supra note 8, at 470 (quoting Samuel Clemens \& Charles Dudley Warner, The Gilded Age 52 (Hartford, Am. Publ'g Co. I 883)). A more persuasive interpretation of the passage comes in Nan Goodman's otherwise uneven account of tort law and literature. See NAN GOODMAN, SHIfTING THE BLAME: LITERATURE, LAW, AND THE THEORY OF ACCIDENTS IN NINETEENTH-CENTURY AMERICA 6597 (I998). In Goodman's view, the passage reflects the crisis of causal attribution confronting the mechanized United States at the end of the century. As I have tried to suggest here, the law at midcentury generally had little difficulty attributing negligence to either the defendant or the plaintiff, though it attributed blame to the injured far more often than we do today. Toward the end of the century, however, the increase in apparently blameless accidents created real difficulties for the law of torts. The steamboat accident in The Gilded Age, it is worth noting, was modeled on the steamboat explosion that killed Clemens's brother.

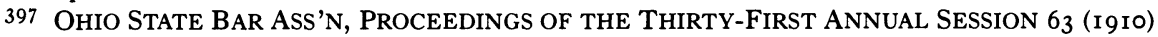
(comments of Judge Robertson).

398 Ohio State Bar Ass'N, Proceedings of the Thirty-Second ANnUAl Session 94 (I9II). 
law judges in nineteenth-century tort cases. Lawrence Friedman and Morton Horwitz, on the one hand, have argued that the common law of tort systematically left victims of industry-related accidents uncompensated. ${ }^{399}$ Gary Schwartz and Peter Karsten, on the other hand, have contended that judges were actually quite sympathetic to the plight of injured plaintiffs. ${ }^{400}$

For the most part, this argument has consisted of debating the motives and decisionmaking behavior of appellate judges in reported cases. It is readily apparent in reading reported torts cases that in appellate courts, many plaintiffs outside of work-accident litigation especially railroad passengers - acquitted themselves quite well, even in states such as New York where courts were considered less friendly to plaintiffs. ${ }^{401}$ But the appellate case reports provide a view of only the top layer in a complicated multi-tiered process. ${ }^{402}$ Looking below the appellate level, it is clear that tort law served as a poor compensation mechanism for accident victims. For one thing, work accident cases were sharply underrepresented among appellate personal injury cases, despite having been the leading category of accidents in the second half of the nineteenth century. ${ }^{403}$ Apparently, most work injuries, for some of the reasons reviewed already, were simply not brought into the tort system at all. ${ }^{404}$ Moreover, studies of one trial court's filings

399 See FRIEDMAN, supra note 8, at 475-76, 485.

400 See Gary T. Schwartz, The Character of Early American Tort Law, 36 UCLA L. REv. 64I, 664-70 (I987); Schwartz, supra note 49, at I 759-65; see also KARSTEN, supra note 49, at 99, 2559 I.

401 This conclusion is based on my reading of every reported personal injury decision in the New York Court of Appeals between I86I and I880.

402 Law-and-society scholars refer to this multi-tiered structure as the 'dispute pyramid.' See Marc Galanter, Adjudication, Litigation, and Related Phenomena, in LAW AND THE SOCIAL SCIENCES I5 I, I83-86 (Leon Lipson \& Stanton Wheeler eds., I986); Marc Galanter, Real World Torts: An Antidote to Anecdote, 55 MD. L. REV. I093, I099-I I02 (1996).

403 In New York, for example, work accident cases brought by employees against their employers represented, by my count, only I0\% (I8 out of 180 ) of all personal injury cases among reported Court of Appeals decisions between I860 and I880, even though the best estimate suggests that work accidents represented one third of accidental deaths and one half of all accidental injuries during the period. See Hoffman, supra note i I, at 5-6, I7.

404 Work accidents were underrepresented in trial court filings as well. Randolph Bergstrom, for example, has found that no work-accident cases were filed in New York City in I870. Although the amount of work-accident litigation as a percentage of total personal-injury litigation in New York increased over the next few decades, Bergstrom's statistics do not distinguish work-accident cases filed against employers (which faced significant legal obstacles) from work-accident cases filed against third parties (which were considerably easier to bring). See BERGSTROM, supra note 58, at 2 I; see also Lawrence M. Friedman, Civil Wrongs: Personal Injury Law in the Late Igth Century, I987 AM. B. FOUND. RES. J. 35 I, 36 I (finding that work-accident suits against employers made up i $2 \%$ of the personal-injury caseload of state courts in Alameda County, California, from I 880 to I 900 and observing that work accidents "were less common on the dockets than one might have expected"); Lawrence M. Friedman \& Thomas D. Russell, More Civil Wrongs: Personal Injury Litigation, I90I-1910, 34 AM. J. LEGAL HIST. 295, 299 (I990) (finding that personal-injury 
indicate that less than 10\% of all claims filed resulted in final judgments entered on behalf of the plaintiff. ${ }^{405}$ To be sure, jury verdicts may have been predominantly in favor of plaintiffs, ${ }^{406}$ but most cases never got that far. ${ }^{407}$ And when we turn from the trial court filings to the records of accident-causing enterprises themselves, the inadequacy of tort law as a compensation mechanism becomes clear. Thomas Russell's study of the claims department of the Oakland Traction Company, a California street railway company, shows that between I 903 and I905, only $58 \mathrm{I}$ of the 3843 passengers injured while riding the railway received any compensation from the company. ${ }^{408}$ The most common amount paid on a claim was between \$IO and \$25. ${ }^{409}$ Moreover, in the thirty-five deaths involving Oakland Traction between 1896 and I906, the company paid an average of $\$ 169$ in each case - less than $\$ 6000$ total - to settle claims by victims' families and to cover medical costs and funeral arrangements. ${ }^{410}$ In twenty of the deaths, Russell finds no payment at all to the victim's family, and in no case did a family receive more than $\$ 300.411$

The problems of faultless accidents and uncompensated injuries brought turn-of-the-century lawyers face to face with the central dilemmas of classical tort law. Nonnegligent accidents happened, it seemed, on an increasingly regular basis, inflicting uncompensated injury on faultless victims. Yet the rationales advanced by the classical

suits between employees and employers accounted for $17.6 \%$ of trial court personal injury filings in Alameda County Superior Court between I90I and I910).

405 See Friedman \& Russell, supra note 404, at 310 ; see also Friedman, supra note 404, at 355 (describing late nineteenth-century tort law as a "system of non compensation").

406 See, e.g., Friedman \& Russell, supra note 404, at 309 (finding that of thirty-eight cases tried before and decided by a jury in Alameda County between I90I and I9IO, twenty-five resulted in jury verdicts for the plaintiff); KARSTEN, supra note 49 , at 99 (calculating on the basis of a number of trial court studies that plaintiffs won in $7 \mathrm{I} \%$ of cases resolved by jury verdicts).

$407 \mathrm{See}$, e.g., Friedman \& Russell, supra note 404 , at 307 (reporting that $80 \%$ of cases filed in Alameda County between I90I and I9I0 never went to trial). The percentage of cases never reaching trial is even higher today. See Marc Galanter \& Mia Cahill, "Most Cases Settle": Judicial Promotion and Regulation of Settlements, 46 STAN. L. REV. I339, I339-40 (1994).

408 Thomas D. Russell, Blood on the Tracks: Turn-of-the-Century Streetcar Injuries, Claims, and Litigation in Alameda County, California, at http://ccwf.cc.utexas.edu/ russell/pubs/bott.html. 409 Id.

$410 I d$.

411 Id. Fishback and Kantor's study of fatal-accident compensation in work-accident cases similarly concludes that in fatal-accident cases compensation was "relatively meager"; a substantial proportion of workers' families in their samples (ranging from $24.4 \%$ in Minnesota to $67.9 \%$ among Illinois coal miners) received no compensation at all, and more than half of those families receiving any compensation from the decedent's employer received less than half of one year's earnings. FISHBACK \& KANTOR, supra note 6, at 34-39. Fishback and Kantor's analysis of nonfatal work-accident cases is somewhat more difficult to interpret, but again substantial percentages of workplace accident victims (ranging from 9.1\% in Minnesota to $72.9 \%$ in Kansas City, Missouri) received no compensation at all, and in most of the samples used, workers who did recover some compensation received too little to compensate them fully for their economic losses. Id. at 39-42. 
lawyers for this category of damnum absque injuria were less and less persuasive in view of the mounting toll of accidents. "[A] system of laws which permit[s] no recovery in so large a percentage of deaths and injuries occurring is unjust," explained one bar association. ${ }^{412}$ Indeed, the negligence standard - which courts had crafted as a guarantor of the boundaries of individual autonomy - had come to license the massive infliction of remediless injury on thousands of Americans each year.

\section{The Dilemmas of Classical Legal Torts}

I. The Recessive Strains of Strict Liability. - Critiques of the negligence standard brought out recessive strains of strict or quasistrict liability in the case law. ${ }^{413}$ In railroad crossing cases in New York, for example, the Court of Appeals solved the problem of damnum absque injuria by sharply limiting the category of faultless accidents. Railroads had "the right to run their trains carefully and prudently on the track which they are by law authorized to construct and use." 414 By the same token, it was "the duty of those who have an equal right to use the highway at the crossing to avoid [the trains]." 415 Whenever there was an accident without the victim's contributory negligence, however, there was sure to be railroad negligence; ${ }^{416}$ and whenever there was an accident without railroad negligence, there was sure to be contributory negligence. ${ }^{417}$ Negligence and contributory

412 Ohio State Bar Ass'N Proceedings, Thirty-Fourth ANnUal Session 49 (I9I3).

413 As Robert Rabin has shown, there were also important areas of no-liability in late nineteenth-century tort law. For example, there was no liability for damages caused by fright. Similarly, landowner liability for damages to trespassers was limited at best. Rabin, supra note 23, at 933-36. My discussion here, however, focuses on the run of the personal injury cases, of which only a relatively small percentage implicated pure no-liability doctrines. Thus for my purposes the interesting tension in late nineteenth-century torts doctrine was between zones of negligence liability and zones of strict cause-based liability.

414 Ernst v. Hudson River R.R., 39 N.Y. 61, 66 (1868).

415 Id. at 66-67.

416 See, e.g., Weber v. N.Y. Cent. \& Hudson River R.R. Co., 67 N.Y. 587, 587-88 (1876) (finding that the mere fact that the railroad had rung its warning bell and carried a light on the train was not enough to absolve it of negligence and liability when the plaintiff had not been contributorily negligent); Roach v. Flushing \& N. Side R.R., 58 N.Y. 626, 626 (1874) (affirming the denial of a railroad's motion for a nonsuit when evidence suggested that the wind had been blowing "so as to carry sound in a direction contrary to that in which the train was going"); Eaton v. Erie Ry., 5 I N.Y. 544, 55.I-52 ( 1873 ) (upholding a negligence verdict against a railroad for backing up over the plaintiff's wagon at a railroad crossing).

417 See, e.g., McGrath v. N.Y. Cent. \& Hudson River R.R. Co., 59 N.Y. 468, 473 (1875) (reversing a verdict for the plaintiff and rejecting the proposition that the railroad's failure to post a flagman excused the plaintiff's carelessness in crossing the tracks); Culhane v. N.Y. Cent. \& Hudson River R.R. Co., 60 N.Y. I33, I 37-38 (I875) (observing that absent negligence on the defendant's part, "[a] collision taking place at noonday ... must have been in part if not wholly the result of carelessness on the part of the servant in charge of the plaintiff's team [of horses]"); Calligan v. N.Y. Cent. \& Hudson River R.R. Co., 59 N.Y. 65 I, 65 I (1874) ("A traveller has no right to omit the exercise of 
negligence swallowed the class of faultless injuries, and crossing cases were thus virtually always said to be due either to railroad negligence or to the contributory negligence of the victim. ${ }^{418}$ Indeed, reading the railroad crossing cases one cannot help but sense that the courts were interested not in negligence and contributory negligence, but rather in who caused the accident. As a result, the law of railroad crossings became effectively a strict liability standard in all cases in which victims had not been contributorily negligent. ${ }^{419}$

Rebuttable presumptions of negligence formed another quasi-strict liability mechanism for redressing the problem of the faultless victim. Hilliard identified in I859 a limited category of cases, including injuries to railroad passengers, in which "a loss, affirmatively proved, will be presumed to have resulted from the negligence of the defendant, throwing upon him the burden of disproving such negligence." 420 Soon thereafter, a series of English decisions held that when people were struck by objects falling from buildings and bridges, the circumstances of the injuries afforded "a presumption that [the building or bridge owner] had not used reasonable care and diligence" in securing the building or bridge. ${ }^{421}$ Absent rebuttal of the presumption, English

proper care in crossing a railroad track, upon the assumption that a train is being run precisely in obedience to a city ordinance [limiting the speed of the train]."); Reynolds v. N.Y. Cent. \& Hudson River R.R. Co., 58 N.Y. 248,252 (1874) (reversing a jury verdict for the plaintiff on the ground that a reasonable jury would have had to find contributory negligence in a case in which the victim "would have saved his life, so far as can be seen from the evidence," by looking before he went out on the railroad tracks); McCall v. N.Y. Cent. R.R. Co., 54 N.Y. 642 (I873) (finding contributory negligence where the victim did not know of a railroad crossing at a particular point on the highway but had passed by it earlier that same day and thus should have known of it); Wilds v. Hudson River R.R., 29 N.Y. 3 I5 (I864) (affirming a nonsuit for the defendant railroad where the plaintiff crossed the tracks in the path of an oncoming train, despite the presence of a factual issue as to the excessive speed of the train).

418 As the New York Court of Appeals explained in 1869 , in railroad crossing cases "the guide of duty on either hand assumes that, if each party is duly careful, neither will be injured." Grippen v. N.Y. Cent. R.R., 40 N.Y. 34, 44 (I869).

419 For example, in cases involving obstructions near the tracks that hindered victims' views of an oncoming train, the New York Court of Appeals consistently held that in the absence of contributory negligence on the victim's part, the railroad company's conduct was unreasonably dangerous. See, e.g., Kissenger v. N.Y. \& Harlem R.R., 56 N.Y. 538, 542-43 (1874) (upholding a jury verdict when boxcars obstructed the plaintiff's view of the tracks); Beisiegel v. N.Y. Cent. R.R., 34 N.Y. 622, 632-33 (I866) (reversing a nonsuit for the defendant when idle freight cars blocked the plaintiff's view of a backing-up train). $C f$. Cordell v. N.Y. Cent. \& Hudson River R.R., 70 N.Y. I I 9, I 24 (I 877) (ruling that obstructions placed by the railroad on tracks go to a determination of the victim's contributory negligence and not the railroad's negligence); Salter v. Utica \& Black River R.R., 59 N.Y. 63 I, 633 (1874) (holding that the question whether a railroad owned an obstruction that blocked a victim's view of the tracks was not relevant to the issue of the railroad's negligence).

420 I HILlIARD, supra note 44, at I28; see also SHEARMAN \& REDFIELD, supra note 46, § I 2 , at IO-I I.

421 See Kearney v. London, Brighton \& S. Coast Ry. Co., 5 L.R.-Q.B. 4I I (I870), aff'd, 6 L.R.Ex. 759 (I87 I) (involving an injury by a brick falling from a railroad bridge soon after the passing 
courts reasoned, the "thing spoke for itself" - res ipsa loquitur. ${ }^{422}$ In the United States, the English res ipsa decisions led to a wave of burden-shifting cases. Landslides occurring in a railroad cut derailing a train; ${ }^{423}$ cinders $^{424}$ and bolts ${ }^{425}$ falling from elevated railways; overhead telegraph wires falling upon the road below; ${ }^{426}$ falling bricks, ${ }^{427}$ buildings, ${ }^{428}$ scaffolds, ${ }^{429}$ or elevators; ${ }^{430}$ collapsing gangway planks; ${ }^{431}$ exploding boilers; ${ }^{432}$ and suddenly starting machinery ${ }^{433}$ - all came at one time or another under the rule shifting the burden of proof to the defendant to disprove that it had been negligent. ${ }^{434}$

Other areas of tort law verged on strict liability as well. Courts held common carriers of passengers to "the utmost care and skill which prudent men are accustomed to use under similar circumstances." 435 Dam owners were strictly liable for the flooding of areas upstream of their dams. ${ }^{436}$ Nuisances interfering with another's enjoyment of his property were "violations of absolute legal rights" and

of a train); Byrne v. Boadle, I59 Eng. Rep. 299, 300 (Ex. Ch. 1863) (finding, in a case involving a barrel of flour that fell from a window of the defendant's building and injured the plaintiff on the sidewalk below, that "[t]here are certain cases of which it may be said res ipsa loquitur, and this seems one of them"). The Byrne case appears to have been the first res ipsa case; from Baron Pollock's "casual utterance, dignified and magnified by the cloak of the learned tongue, there has grown by a most extraordinary process the 'doctrine' of res ipsa loquitur." William L. Prosser, Res Ipsa Loquitur in California, 37 CAL. L. REV. I83, I83 (1949).

422 Kearney, 6 L.R.-Ex. at 76I-62; see also Byrne, 159 Eng. Rep. at 300.

423 Gleeson v. Va. Midland Ry. Co., I40 U.S. 435, $44 \mathrm{I}-42$ (I89I).

424 Lowery v. Manhattan Ry. Co., I N.E. 608, 6 I I (N.Y. I885).

425 Volkmar v. Manhattan Ry. Co., 3 I N.E. 870 , 87 I (N.Y. I892).

426 Thomas v. W. Union Tel. Co., I00 Mass. I56, I57 (I868).

427 Sheridan v. Foley, 33 A. 484,485 (N.J. I895).

428 Mullen v. St. John, 57 N.Y. 567, 569-70 (1874); Vincett v. Cook, 4 Hun 318 (N.Y. Sup. Ct. I875).

429 Flynn v. Gallagher, 52 N.Y. Super. 524,525 (N.Y. Super. Ct. I 885 ).

430 Griffin v. Manice, 59 N.E. $925,927-28$ (N.Y. I 901 ).

431 Eagle Packet Co. v. Defries, 94 Ill. 598, 602 (1880).

432 Grimsley v. Hankins, 46 F. 400, 40 I (S.D. Ala. I89I); see also Illinois Cent. R.R. Co. v. Phillips, 55 Ill. I94, 20 I (1870).

433 Blanton v. Dold, I8 S.W. I I49, I I 5 I (Mo. I892); see also Ross v. Double Shoals Cotton Mills, 52 S.E. I2I, I 22-23 (N.C. I 905 ) (applying res ipsa loquitur to suddenly starting machinery but holding that under North Carolina law, res ipsa gets a case to the jury as a matter of law but does not shift the burden of proof to the defendant).

434 The application of the res ipsa loquitur rule was extraordinarily haphazard. For every case applying the doctrine, another refused to apply it despite similar circumstances. See, e.g., Robinson v. Charles Wright \& Co., 53 N.W. 938, 940 (Mich. I892) (refusing to apply res ipsa in the case of the sudden malfunction of properly constructed machinery); Kirby v. President of Del. \& Hudson Canal Co., 62 N.Y.S. I I IO, I I I (App. Div. I900) (finding that an explosion of hot water apparatus did not fall under the res ipsa rule); Piehl v. Albany Ry., 5 I N.Y.S. 755, 756-57 (App. Div. I898), aff'd, 57 N.E. I I 22 (N.Y. I 900) (reaching the same conclusion as the Robinson court); May v. Berlin Iron-Bridge Co., 60 N.Y.S. 550, 553 (App. Div. 1899) (refusing to apply res ipsa in a case involving falling iron trusses).

435 SHEARMAN \& REDFIELD, supra note $46, \S 266$, at 296-97.

436 I HILlIARD, supra note 44 , at 87. 
thus "strict legal injuries." 437 Hilliard wrote that the mere use of reasonable precautions did not vindicate a defendant in a blasting case. ${ }^{438}$ According to Cooley, hunters trespassing on private lands were strictly liable for any damages caused to the landowner. ${ }^{439}$ Possessors of domestic animals were strictly liable for any ordinary damages to crops resulting from their escape, and possessors of wild animals were strictly liable for any damages caused by their escape. ${ }^{440}$ By the same token, extrahazardous activities such as the storage of nitroglycerin ${ }^{441}$ or petroleum, ${ }^{442}$ excavations, ${ }^{443}$ and the production of noxious substances $^{444}$ could, in certain circumstances, lead to strict liability for harm caused. ${ }^{445}$

Yet the move to strict liability standards could not rescue the precarious intellectual project of classical tort doctrine. A cause-based approach to liability might, to be sure, have gone a long way toward compensating nonnegligent victims. But even under a strict liability system, intractable problems of causation would have made it impossible to make bright-line distinctions among the boundaries of the various parties' spheres of interest. 446 Both parties to a bilateral accident, after all, were necessarily but-for causes of the accident. And in cases involving extrahazardous activities or nuisances, for example, the determination of which party - injurer or injured - had caused the accident would have required a prior (and circular) inquiry into who had been entitled to do what. ${ }^{447}$ A cause-based approach was therefore indeterminate in important classes of cases, and even if classical tort law had adopted strict liability standards more widely, it still could not have clarified the boundary lines between persons.

Still more problematic for the conceptual architecture of the classical law of torts, the development of strict liability rules sharply undermined the intellectual clarity of tort doctrine. Even as recessive strains of strict liability emerged, they stood side by side with the stilldominant negligence standard. Treatises thus announced negligence as the general rule in accident cases while at the same time listing a

\footnotetext{
437 Id. at $\mathrm{I} 26$.

438 Id. at I 27 (citing Scott v. Bay, 3 Md. 43 I (I853)).

439 COOLEy, supra note 46 , at 328-29.

440 Id. at $329,337-50$.

441 Bradford Glycerine Co. v. St. Marys Woolen Mfg. Co., 54 N.E. 528, 530-3I (Ohio I899).

442 Berger v. Minneapolis Gaslight Co., 62 N.W. 336, 337-38 (Minn. 1895).

443 Mears v. Dole, I35 Mass. 508 (1883).

444 Frost v. Berkeley Phosphate Co., 20 S.E. $280,283-84$ (S.C. 1894).

445 COOLEY, supra note 46 , at $570-7 \mathrm{I}$.

446 See Fletcher, supra note 236, at 66-67; Mark Kelman, The Necessary Myth of Objective Causation Judgments in Liberal Political Theory, 63 CHI.-KENT L. REV. 579 (1987); Stephen R. Perry, The Impossibility of General Strict Liability, I CANADIAN J.L. \& JURISPRUDENCE I47, I54-59 (I988).

447 Kelman, supra note 446 , at 586.
} 
growing number of categories of strict or quasi-strict liability as ad hoc exceptions to the negligence rule. In short, the carefully constructed architecture of the classical law of torts was losing its coherence and form. The law of torts retreated from conceptual order into doctrinal stalemate, caught between competing strands in the increasingly messy case law.

2. The Limits of Consent. - The rule of assumption of risk had offered a contract-based approach to bringing tort doctrine into line with classical liberal principles. But it was increasingly apparent that to allow parties to contract into their own liability rules would not settle the dilemmas of tort law. As early as the I86os, courts began to confront a wave of attempts by railroad companies to adjust by contract their tort liability exposure for injuries to passengers and workers. Tickets issued to passengers or to stockmen accompanying cattle in shipment increasingly included printed waivers of liability for personal injury. ${ }^{448}$ Employment contracts released employers from liability for the personal injuries of their workers, ${ }^{449}$ sought to replace state statutes of limitations with restrictive thirty-day notice requirements ${ }^{450}$ or to waive state safety regulations, ${ }^{451}$ and attempted to condition the filing of personal injury suits on medical examinations by company physicians. ${ }^{452}$

With few exceptions, courts sharply curtailed the capacity of railroads and other firms to contract out of their common law liability for injuries to passengers and employees. Such contracts, in the truncated phrase of the late nineteenth-century courts, were void as "against public policy." Yet despite the unelaborated references to public policy, one can tease out of the cases at least three discrete rationales for holding contractual waivers of liability unenforceable. Each rationale,

448 See, e.g., N.Y. Cent. R.R. Co. v. Lockwood, 84 U.S. 357 (1873) (discussing a contractual waiver of liability for injury to a drover accompanying livestock); Chi., Rock Island \& Pac. Ry. Co. v. Hamler, 74 N.E. 705, 705-06 (Ill. I 905) (reviewing a waiver of liability for porters employed by the Pullman Company); Ohio \& Miss. Ry. Co. v. Selby, 47 Ind. 47 I, 474-75 (I874) (reviewing a waiver of liability for carrying a stockman); Doyle v. Fitchburg R.R. Co., 44 N.E. 6I I, 6I I (Mass. I896) (reviewing a waiver of liability for paying employees); Bates v. Old Colony R.R. Co., I 7 N.E. 633, 638 (Mass. I 888) (reviewing a waiver of liability for carrying an express messenger); Ill. Cent. R.R. Co. v. Crudup, 63 Miss. 29I (I885) (reviewing a waiver of liability for carrying a mail agent); Bissell v. N.Y. Cent. R.R. Co., 25 N.Y. 442, 446-47 (I862) (reviewing a waiver of liability for injuries to paying passengers); Cleveland, Painesville \& Ashtabula R.R. Co. v. Curran, I9 Ohio St. I, 23 (I869) (stockman); Pa. R.R. Co. v. Henderson, 5 I Pa. 3 I5, 3 I6 (I865) (paying passengers).

449 See, e.g., Hissong v. Richmond \& Danville R.R. Co., 8 So. 776, 776 (Ala. I89I); Kan. Pac. Ry. Co. v. Peavey, 29 Kan. I69, I74-75 (1883); Purdy v. Rome, Watertown, \& Ogdensburgh R.R. Co., 26 N.E. 255,255 (N.Y. I 89 I).

450 Mumford v. Chi., Rock Island \& Pac. Ry. Co., I04 N.W. I I35, I I37 (Iowa I905).

451 See, e.g., Chi. \& Erie R.R. Co. v. Lawrence, 82 N.E. 768 (Ind. I907); D.H. Davis Coal Co. v. Polland, 62 N.E. 492 (Ind. I 902); Lassiter v. Raleigh \& Gaston R.R. Co., 49 S.E. 93 (N.C. I 904). 452 Galveston, Houston \& San Antonio Ry. Co. v. Hughes, 9I S.W. 643 (Tex. Civ. App. I905). 
in its own way, pointed toward the impracticability of the elegant conceptual structure of classical tort law.

Tort doctrine aimed to set the bounds of each individual's duties and rights in order to clarify the scope of freedom in civil society. But cases voiding consensual waivers of liability indicated, first, that the law placed substantive limits on what an individual could do even with respect to purely self-regarding activity. Just as the criminal prohibition on suicide restricted individual liberty in order to protect life, the right to sue for damages arising out of negligence was unwaivable because private tort actions served as the best "safeguard" against the destruction of life. "The state has an interest of the highest degree in the preservation of its citizens' lives," explained Shearman and Redfield, and the protection that the negligence regime afforded to each individual was thus "of such value to the state that it should not allow it to be waived." 453

Second, many believed that such waivers of liability revealed the extent to which inequality undermined the classical framework. To uphold contractual waivers of liability between railroads and their passengers or employees, Seymour Thompson observed, was to "ignore the unequal situation of the laborer and his employer." 454 The appeal of the inequality argument diminished during the first decades of the twentieth century, largely because it was exceedingly difficult to distinguish authentic expressions of consumer or worker preferences from the effects of employer power. ${ }^{455}$ Nonetheless, this critique of contractual waivers remained strong into the early twentieth century. ${ }^{456}$

Third, and ultimately most devastating for the classical tort system, the cases suggested that the notion of individuals as self-contained rights bearers, whose boundaries could be definitively set out if only the law of torts were sufficiently clarified, was simply impossible. ${ }^{457}$ Agreements between parties as to their rights, duties, and remedies, it turned out, inevitably affected third parties. When a railroad contracted out of its liability to one passenger or employee, its incentives to take care of other passengers and employees would necessarily diminish. The U.S. Supreme Court noted precisely this consequence in I873, when it observed that such private "individual contracts" sup-

\footnotetext{
453 SHEARMAN \& REDFIELD, supra note $46, \S 274$, at 308.

4542 THOMPSON, supra note $23 \mathrm{I}$, at 1025.

455 See Charles W. McCurdy, The "Liberty of Contract" Regime in American Law, in THE STATE AND FREEDOM OF CONTRAC'T I6I, I6I-97 (H.arry N. Scheiber ed., I998).

456 See id. at $\mathrm{I} 8 \mathrm{I}$.

457 Modern critiques of the attempt to work out a libertarian theory of torts based on boundarycrossing are critiques of strict liability, largely because Richard Epstein, the leading contemporary libertarian torts theorist, advocates a strict liability approach. The critiques are equally applicable, however, to a negligence regime theorized around similar attempts to carve out bright-line spheres of autonomy. See sources cited supra note 446.
} 
planting the law of common carriers affected the "public interest."458 Similarly, the Ohio Supreme Court ruled the waiver of liability in a stockman's rail pass unenforceable because of the ripple effects such waivers might have on third parties. "It cannot be denied," the court explained, "that pecuniary liability for negligence promotes care; and if public carriers in conducting their business can graduate their charges so as to discharge themselves from such liability, the direct effect will be to [diminish] the motives for diligence." ${ }^{459}$ By the turn of the century, the problem of increased risk to third parties arising out of waivers of liability had become increasingly central to courts' refusals to enforce such waivers. ${ }^{460}$

As one New York court observed, whether one person could by contract exonerate another from liability for an injury inflicted by the latter's own negligence was "quaestio vexata in the jurisprudence of England and this country." 461 Indeed, the problem was all the greater given that the doctrine of assumption of risk - a mainstay of tort law's doctrinal structure - was itself all about waiving the tort liability rules imposed by law and setting new rules between employer and employee. When an employer notified an employee of a particular defect in machinery, or when an employee knew of and consented to a particular failure in the employer's obligations of care, the employee was said to waive his right to sue for the employer's negligence. ${ }^{462}$ The courts required consent but often deemed the mere failure to quit sufficient to constitute consent. ${ }^{463}$ So, too, the fellow servant doctrine represented a contractual means by which employers transferred liability for work accidents to their workers. Thus, although the question was fairly well settled that contractual waivers were unenforceable, a series of exceptional or dissenting cases emerged as courts sought to reconcile the apparent "public policy" problems of such

458 N.Y. Cent. R.R. Co. v. Lockwood, 84 U.S. 357, 378-79 (1 873 ).

459 Cleveland, Painesville \& Ashtabula R.R. Co. v. Curran, I9 Ohio St. I, I4 (I869); see also Ill. Cent. R.R. Co. v. Beebe, 50 N.E. I019, 1022 (Ill. I898) (refusing to enforce a waiver on the ground that a stockman cannot waive liability rules rooted in "public policy"); Doyle v. Fitchburg R.R. Co., 44 N.E. 6 II 6 12 (Mass. I896) (voiding a waiver of liability between a railroad and a paying passenger on the ground that the passenger could not waive the railroad's "public" duties to take care); Lake Shore \& Mich. S. Ry. v. Spangler, 8 N.E. 467,470 (I 886) (holding a waiver of employer liability unenforceable on grounds that "[s]uch liability is not created for the protection of the employees simply"); McCurdy, supra note 455 , at I 77-79.

460 See McCurdy, supra note 455 , at 178.

461 Runt v. Herring, 2 I N.Y.S. 244, 246 (Ct. Comm. Pl. I892) (voiding an employee-plaintiff's agreement to hold an employer harmless even for injuries suffered because of the employer's negligence).

4622 THOMPSON, supra note $23 \mathrm{I}$, at 1008.

463 See, e.g., Greenleaf v. Dubuque \& Sioux City R.R. Co., 33 Iowa 52, 58 (187 I); Kroy v. Chi., Rock Island \& Pac. R.R. Co., 32 Iowa 357, 36I (I87 I); Crutchfield v. Richmond \& Danville R.R. Co., 78 N.C. 300,302 (I878); 2 THOMPSON, supra note 23 I, at 1008. Courts split on this point, however. See KARSTEN, supra note 49 , at II $2-27$. 
waivers with the principles of the doctrinal framework. In New York, for example, one court held that the assumption of risk principle allowed a worker to waive the protections of safety regulations. ${ }^{464}$ Elsewhere, courts enforced employment agreements waiving the right to sue for damages incurred while on employers' trains going to and from work. ${ }^{465}$ Similarly, some courts enforced railroad company liability waivers by construing them to have been executed by the railroads in their capacity as so-called "private carriers" rather than in their capacity as common carriers. ${ }^{466}$

Ultimately, as in the law's oscillation between negligence and strict liability, conflict between the waiver cases and the assumption of risk rule produced doctrinal stalemate. Classical tort law simply proved unable to draw bright lines separating individuals from one another or separating individuals from the state. Private rights, it appeared, inevitably collided with one another as well as with public interests.

If the dream of constructing a jurisprudence roughly consistent with classical liberalism ultimately proved unable to separate out the bounds of each individual's duties and rights, it was likely that the entire doctrinal edifice would collapse - as, of course, it did. By the third decade of the twentieth century, almost every American jurisdiction had replaced tort law with an administrative compensation system for work accidents, the most important category of personal injuries. But to move to workmen's compensation is to jump to the end of the story, to tell it working back from its conclusion. In a more immediate sense, the shortcomings of classical tort law precipitated a scramble for alternatives to the law of torts among working-class families seeking protections against the mounting risk of injury and death.

\section{THE FIRST FIRST-PARTY INSURANCE SYSTEM}

Legend has it that on October 27, I868, John Jordan Upchurch of Meadville, Pennsylvania, established the first American cooperative

464 De Young v. Irving, 38 N.Y.S. 1089, I092 (App. Div. 1896). De Young was a truly astounding decision. A New York factory law provided, inter alia, that no woman under twenty-one years of age "shall be allowed to clean machinery while in motion." Ch. $673, \S 8,1892$ N.Y. Laws I 376 . The defendant angrily ordered his employee (the plaintiff, a woman under twenty-one years of age) to clean the machinery in a crinoline machine even though it was in motion. The plaintiff complied and caught her hand in the machinery, inflicting a severe burn. The plaintiff based her subsequent tort action against her employer on the latter's violation of the factory law. The Appellate Division, however, affirmed the dismissal of her case on the ground that the "plaintiff knowingly entered upon the forbidden task, and thereby waived the benefit of the statute." De Young, 38 N.Y.S. at 1092 .

465 Peterson v. Seattle Traction Co., 63 P. 539, 547-48 (Wash. 1900).

466 See, e.g., Cleveland, Cincinnati, Chi. \& St. Louis Ry. Co. v. Henry, 83 N.E. 7 10, 7 I 2 (Ind. I908). 
fraternal insurance association, the Ancient Order of United Workmen. As retold at countless cooperative insurance conventions and lodge gatherings during the late nineteenth century, Upchurch founded the United Workmen primarily as a labor organization. A Civil War veteran and master railroad mechanic, Upchurch hoped that the United Workmen would foster "ideas of right and justice between man and man," provide "one united body for the protection of [workers'] interest against all encroachments," and elevate "labor to that standard it is justly entitled to." 467 The United Workmen thus appeared to adopt a broad platform for the advancement of workers' interests, similar in many ways to the programs for workingmen's protection that labor groups such as the Knights of Labor, founded in I869, adopted during the same years. ${ }^{468}$ Within a year of its establishment, however, the United Workmen moved in a different, though not unrelated, direction. The industrial accident problem on the railroads generated a strong need among railway workers such as Upchurch for some sort of insurance against death and disability. Thus, the United Workmen became primarily an association for the mutual insurance of its workingclass membership. Indeed, the United Workmen very quickly became the leading early participants in the now little-known but remarkably important workingmen's cooperative self-insurance system of late nineteenth-century America.

The story of Upchurch's founding of the first cooperative workingmen's insurance association is likely little more than a useful, if apocryphal, myth of origins for the vast cooperative disability and life insurance movement that sprang up practically overnight in post-Civil War America. If the myth of Upchurch's founding act was improbable, however, the workingmen's organizations of the 1890 s were correct in seeing the development of cooperative insurance in the postCivil War years as an extraordinary phenomenon that required explanation.

Late nineteenth-century cooperative self-insurance associations played a critical but now almost entirely ignored role in compensating accident victims, especially work accident victims. Indeed, by the I 880 s and I89os, cooperative first-party insurance societies were the leading source of systematic compensation for accidental disability and death. In 1860 cooperative life and disability insurance was a bit player in a tiny industry. By the $\mathrm{r} 890 \mathrm{~s}$, however, it was the leading form of insurance in a life insurance market that had increased in size

467 WALTER BASYe, History AND OPERATION OF FRATERNAL INSURANCE 9-IO (I9I9); see M.W. SACKETT, EARLY HISTORY OF FRATERNAL BENEFICIARY SOCIETIES IN AMERICA: ORIGINAL GROWTH I 868-I880, at 27 (I9I4).

468 See generally FiNK, supra note 154. 
thirty times over. ${ }^{469}$ The cooperatives had become more important, in terms of number of policies and total insurance in force, than the commercial life insurance industry - stock and mutual companies combined. ${ }^{470}$ And in the last two decades of the nineteenth century, it appears that an astonishing one in three American workingmen belonged to a cooperative insurance association of one sort or another. ${ }^{471}$ In urban areas in the East and Midwest, the numbers were often even higher. In short, cooperative insurance had developed in the span of two decades into an institution of the first rank in American life.

\section{A. Cooperative First-Party Insurance and Insurance Markets}

Students of accident law have paid little attention to workingmen's cooperative insurance associations. Indeed, the standard accounts of the development of American accident law appear wholly unaware of the experiment with first-party insurance at the turn of the twentieth century. This lack of interest is striking. First-party insurance has been one of the most widely debated alternatives to our contemporary tort law regime. Beginning in the mid-I 960 s with Robert Keeton and Jeffrey O'Connell's proposal for a first-party automobile accident insurance program, many have argued that first-party insurance offers cheaper, surer, and fairer compensation for accident victims than the tort system does. ${ }^{472}$ George Priest, for one, argues that first-party insurance effectively limits extravagant post-accident claims by victims. In his view the third-party tort system functions as a forced insurance system that systematically overinsures because it compensates nonpecuniary losses as well as pecuniary losses, and because it creates poor incentives for accident victims to mitigate their damages. ${ }^{473}$ Similarly, Patrick Atiyah has recently proposed shifting the English accident compensation regime to a first-party insurance basis by abolishing the action for personal injury. ${ }^{474}$ According to Atiyah, the move to firstparty insurance would minimize the sum of accident costs by reducing administrative costs and eliminating the award of damages for pain and suffering, for which individuals rarely purchase protection in pri-

469 See J. Owen Stalson, Marketing Life Insurance: Its History in America 8i6 (1942).

470 See infra pp. 797-98.

471 Infra pp. 798-99; see David T. BeIto, From Mutual Aid to Welfare State: FRATERNAL SOCIETIES AND SOCIAI. SERVICES, I890-1967, at 14 (2000); B.H. Meyer, Fraternal Beneficiary Societies in the United States, 6 AM. J. Soc. 646-47 (I901) (estimating that one in fifteen Americans belonged to a cooperative insurance society at the turn of the century).

472 See KeEton \& O'CONNELl, supra note 2 , at 268-72; JEFFREY O'CONNELl \& C. BRIAN KELly, THE BlAME GAME: INJURIES, INSURANCE, AND INJUSTICE I I 3-22 (I987) (discussing the efficacy of first-party insurance and the degree of its acceptance).

473 Priest, Current Insurance Crisis, supra note I, at I553-60.

474 Atiyah, supra note I, at 35-43. 
vate insurance markets. ${ }^{475}$ Moreover, in Atiyah's view, a first-party system would ensure that recovery for disability does not turn on arbitrary distinctions among the causes of an accident, such as whether someone's negligence caused the accident, or whether the accident took place at work or in a car. ${ }^{476}$

As contemporary proponents of first-party insurance concede, selfinsurance mechanisms face significant obstacles. Disability insurance today is generally the least common form of private loss insurance in Western economies. ${ }^{477}$ In the I990s only one half of all paid workers had private short-term disability insurance, and fewer than one quarter had long-term disability coverage. ${ }^{478}$ Moreover, total disability insurance payments in the I 980 s amounted to roughly $\$ 6$ billion annually, less than five percent of the total compensation paid to victims of disability resulting from accidents. ${ }^{479}$

The chief problem for disability insurance is that it is especially susceptible to two difficulties endemic to insurance markets: adverse selection and moral hazard. ${ }^{480}$ Adverse selection describes the tendencies of high-risk insureds to seek out insurance and to stay in insurance pools, and of low-risk insureds to opt out of insufficiently subcategorized insurance pools that require them to subsidize the insurance of higher-risk insureds. Absent information sufficient to subcategorize insurance pools on the basis of the particular risk profiles of the insureds, adverse selection can lead to the eventual unraveling of insurance pools, as low-risk insureds abandon high-risk insureds. ${ }^{481}$ Moral hazard describes the effects of insurance coverage on insureds' incentives to avoid incurring covered costs in the first place and to mitigate losses once covered costs have been incurred. ${ }^{482}$ These two insurance market problems each affect disability insurance acutely. On one

475 See id. Steven Croley and Jon Hanson have recently argued that individuals do in fact desire to purchase pain and suffering insurance, but that impediments in the insurance market prevent them from doing so. Steven P. Croley \& Jon D. Hanson, The Nonpecuniary Costs of Accidents: Pain-and-Suffering Damages in Tort Law, I08 HARV. L. REV. I787, I791-92 (I995).

476 See Atiyah, supra note I, at 35-43.

477 See Michael J. Graetz \& Jerry L. Mashaw, True Security: Rethinking American SOCIAL INSURANCE 2 IO-26 (1999) (analyzing problems with the provision of disability insurance and providing examples from Western countries); Abraham \& Liebman, supra note 5, at 8I-82.

478 Abraham \& Liebman, supra note 5, at 8I-82.

479 Id. at 82 ; see also COMPENSATION FOR ACCIDENTAL INJURIES, supra note II6, at I08; Abraham \& Liebman, supra note 5 , at 102-03.

480 See GRAETZ \& MASHAW, supra note 477 at 70 .

481 KenNeth S. Abraham, Distributing Risk: Insurance, Legal Theory, AND PubliC POLICY 14-I5 (1986); Jon D. Hanson \& Kyle D. Logue, The First-Party Insurance Externality: An Economic Justification for Enterprise Liability, 76 CORNELL L. REV. I29, I38-4I (1990); see also Priest, Current Insurance Crisis, supra note I, at I54I-48, I553-63 (explaining the dynamics involved in the selection and unraveling of insurance pools).

482 See ABRAHAM, supra note 48I, at I4-15; Hanson \& Logue, supra note 48I, at 138-39; Priest, Current Insurance Crisis, supra note I, at 1547-48. 
hand, insureds often know much more about their likelihood of disability than do insurers. As a result insurers are often unable to categorize risk pools effectively, and lower-risk insureds will thus be required to subsidize high-risk insureds or to leave the insurance market altogether. On the other hand, it is exceedingly difficult to determine precisely what is or is not a disability and to measure the extent and the nature of disabilities. Thus it is extremely expensive for insurers to police the moral hazards (and sometimes the outright fraud) associated with overclaiming in the event of a potentially disabling accident.

The genius of cooperative insurance in post-Civil War America was its creative response to the endemic problems of adverse selection and moral hazard in disability insurance markets. ${ }^{483}$ Cooperative insurance associations adopted a set of premodern fraternal social rituals and symbols such as secret passwords, secret handshakes, and elaborate initiation rites. Though overwrought and perhaps even silly to our eyes, these rituals served the critical insurance functions of combating adverse selection and moral hazard. Cooperative association insurance aimed to forge norms of solidarity among members that would discourage the self-interested departure of low-risk insureds from the insurance pool, as well as reduce the incidence of self-seeking claims on the pool. Thus, although the late nineteenth century witnessed a number of experiments in first-party insurance schemes for life and disability insurance, none of them caught on in the same way that cooperative insurance did, especially among working-class families. The cooperatives' peculiar design around social ritual and brotherly spirit made them ideal vehicles for minimizing adverse selection and moral hazard problems in disability insurance.

\section{B. Insurance Associations and the Cooperative Strand of Free Labor Ideology}

The ability to combat the special problems of disability insurance markets was necessary to the success of the cooperative insurance movement, but this ability is not sufficient to explain the movement. In particular, the need to address problems of moral hazard and ad-

483 Over the past several decades the concept of moral hazard has played a leading role in scholarly accounts of insurance and tort law. As Tom Baker has shown in his account of the changing meanings of moral hazard since the early nineteenth century, however, the crudest uses of moral hazard in today's literature are little more than opportunistic claims of scientific objectivity on behalf of arguments against helping the poor, the sick, and the injured. See Tom Baker, On the Genealogy of Moral Hazard, 75 TEX. L. REV. 237, 239-40 (1996). Baker's story of the historical evolution of the moral hazard concept does not, as I read it, seek to argue against the descriptive or normative value of moral hazard altogether. See $i d$. at 290 (observing that the concept of moral hazard may be useful in understanding certain issues in tort law). Rather, it offers a note of caution for those who see in the idea of moral hazard proof that "less is more" in government assistance programs. See id. at 238-39, 288-89. 
verse selection cannot explain the particular approach to mutual insurance that American workingmen adopted in the 1880 and 189os. For in addition to being a particularly economical insurance mechanism, the cooperative insurance societies represented one among a number of attempts by late nineteenth-century American workingmen to adapt the Civil War ideal of masculine free labor citizenship to a newly industrializing republic.

Just as they have generally been ignored in the accident law literature, cooperative insurance associations have traditionally received scant interest from historians. Some historians in a Tocquevillean vein have touched on them as examples of American civil society's associationalist patterns. ${ }^{484}$ Others have viewed American fraternal societies, whose trappings many cooperative insurance societies adopted, as case studies in the construction of manliness. ${ }^{485}$ Most recently, a group of historians (inspired by cuts in social insurance programs) have advanced the nineteenth-century model of cooperative societies as a private sector alternative to state entitlement programs. ${ }^{486}$ As we shall see, this recent optimism about private alternatives to social insurance is misplaced; the poorest and sickest Americans in the late nineteenth century were rarely able to purchase meaningful amounts of insurance for anything other than funeral expenses. ${ }^{487}$

But with the exception of this post-welfare state scholarship, the cooperative insurance associations rarely fit into the analytic structures employed by historians writing about the Gilded Age and the Progressive Era. Unlike labor organizations ranging from the relatively conservative American Federation of Labor to the radical Industrial Workers of the World, the cooperatives did not organize workingmen for purposes of collective bargaining in the capitalist workplace. And

\footnotetext{
484 See Arthur M. Schlesinger, Biography of a Nation of Joiners, 50 AM. HIST. REV. I, I6-I9 (1944). A recent update of the Toquevillean strand of studies of American fraternal associations, including cooperative fraternal insurance associations, can be found in the political science literature on social capital and civic associationalism. See Robert D. PUTNAM, Bowling Alone: The Collapse and Revival of American Community 383-93 (2000); Theda Skocpol, Advocates Without Members: The Recent Transformation of American Civic Life, in CIVIC ENGAGEMENT IN AMERICAN DEMOCRACY 46I, 499-504 (Theda Skocpol \& Morris P. Fiorina eds., I 999).

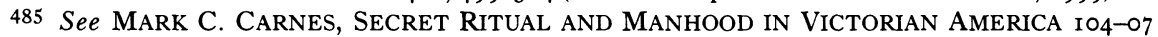
(I 989); MARY ANN Clawson, CONSTRUCTING BROTHERHOOD: ClaSs, GENDER, AND FRATERNALISM 45-52 (I989); LYNN DUMENIL, FREEMASONRY AND AMERICAN CULTURE, I880-I930, at $72-$ I I I (I984).

486 See, e.g., David G. Green, Reinventing Civil Society: The Rediscovery of Welfare Without Politics i 47-53 (1993); William A. Schambra, All Community is Local: The Key to America's Civic Renewal, in COMMUNITy WORKS: THE REvival OF CIVIL SOCIETy IN America 44 (E.J. Dionne ed., i998); Michael TANner, The End of Welfare: Fighting PoverTy IN THE CIVIL Society I 34-39 (I996); Stephen Davies, Two Conceptions of Welfare: Voluntarism and Incorporationism, SOC. PHIL. \& POL'Y, Summer I997, at 39, 55-58; David Schmidtz, Guarantees, SOC. PHIL. \& POL'Y, Summer I 997, at I. Cf. BEITO, supra note 47I, at 3-4.

487 See infra pp. 82 I-22, 83I-32.
} 
unlike the Farmers' Alliances of the I880s, which formed the People's Party (or "Populists") of the I89os, the cooperatives did not organize a political party. Thus cooperative fraternal insurance associations are by and large treated as curiosities, representing little more than the joiner mentality of a nation of Babbitts. ${ }^{488}$ Such lack of interest in the cooperative insurance movement, however, has blinded historians to the importance of cooperative societies in the lives of everyday Americans in the 1880 s and 1890 s.

The cooperative insurance system embodied not just a convenient mechanism for self-insurance, but also an alternative normative conception of the organization of American social life. Like the post-Civil War workingmen's associations out of which the Ancient Order of United Workmen developed, and like the Populists and farmers' associations with which the cooperatives shared many commitments, insurance associations advanced a vision for the cooperative reconstruction not just of accident law, but of social conditions and the American economy more generally.

Injuries to workingmen highlighted the inability of late nineteenthcentury wage-earners to achieve the financial independence of the antebellum master craftsman; moreover, they drove home the fragility of the domestic sphere in a wage-earning economy. Cooperative selfinsurance offered a means of adapting the free labor ideal of manly protection of the family to a wage-earning and industrializing world. In so doing it also advanced a critique of the competitive system that generated the accident problem in the first place. For many cooperationists, the socioeconomic changes that prompted collective efforts to secure compensation for disability also called for - and perhaps even required - more than mere remedial measures to address the externalities generated by economic life. For these advocates of cooperation, industrialization's accident toll was a fundamental flaw in the late nineteenth-century social order - a flaw that demanded an equally fundamental reorganization of economic and political life.

The cooperative vision of the insurance associations, however, was deeply ambiguous in its implications. Like late nineteenth-century cooperatives more generally, the cooperative insurance associations were inextricably caught between competing meanings of cooperation. If some cooperative insurance advocates saw cooperation as an alternative to competitive capitalism, others believed that the cooperatives stood for the capacity of private market mechanisms to address and solve the social problems attendant to an industrializing economy. For

488 The reference here is to Sinclair Lewis's caustic send-up of striving middle-class values in Babbitt, whose main character is a member of an especially unattractive fraternal club. See SINCLAIR LEWIS, BABBITT (I922). 
this latter group of cooperationists, the great promise of cooperation lay in its capacity to inculcate the virtues of thrift and self-reliance on which competitive capitalist markets depended.

The cooperative associations' attempt to reconstruct American social life came to a head in the first decade of the twentieth century, when the leading cooperative insurance societies sought to stave off competing forms of social insurance by organizing into national trade associations and enacting legislation that would allow them to form a quasi-public insurance system. The cooperatives' attempt to establish themselves as the administrators of such an insurance system was hindered in part by the persistence of the voluntarist strand within the cooperative movement. Moreover, by the turn of the century the law of insurance made it increasingly difficult for the associations to overcome the problems of moral hazard and adverse selection. Perhaps the most important factors in the ultimate decline of cooperative insurance, however, were two developments - unique to the United States - around the turn of the twentieth century. First, an influx of new immigrants from Southern and Eastern Europe into the lowest tiers of the American labor market created a large number of American workingmen who were unable to afford even the relatively inexpensive insurance offered by the late nineteenth-century cooperative insurance associations. ${ }^{489}$ Second, in precisely the same years, the United States witnessed a critical reevaluation of the ideological meaning of work and an accompanying reorganization of the American workplace. Work accidents, after all, were the core of the accident crisis in the years after the Civil War. And as we shall see, changes in the way that Americans thought about and organized the workplace generated new skepticism about the capacity of workers themselves to engage in effective accident prevention and self-insurance.

For all of these reasons, the cooperative vision of an alternate legal order never came to fruition. Yet the cooperative alternative of the late nineteenth century represents an important path not taken in American political economy and a lost alternative in American accident law.

\section{The Varieties of First-Party Insurance}

Notwithstanding the cooperatives' myth of origins in John Upchurch in 1868 , post-Civil War workingmen's insurance societies developed out of a long tradition of groups dedicated to mutual insurance. English friendly societies that claimed to have their origins in 
antiquity became important institutions in the eighteenth century. ${ }^{490}$ In the United States, associations for mutual protection existed in a number of different forms throughout the first half of the nineteenth century. ${ }^{491}$ Indeed, mutual insurance pools sprang up across the United States and Western Europe during the first half of the nineteenth century among a wide array of groups to protect against a variety of hazards such as fire and maritime losses. ${ }^{492}$

Nonetheless, it was only after the Civil War that the number and significance of first-party insurance systems increased sharply. The expansion of markets and the spread of new industrial technologies, especially the railroad, occasioned new experimentation with a variety of first-party insurance mechanisms. Cooperative insurance associations were the most prominent of the experiments in first-party insurance for American workingmen. By the 1890 s they were the dominant mechanism for self-insurance among Americans generally, exceeding commercial life insurance in both number of policies and amount of insurance in force. But a number of other mechanisms for selfinsurance became increasingly significant in the postwar years. The most important of these mechanisms were commercial life insurance, commercial accident insurance, so-called "industrial" insurance, and trade union mutual insurance and relief funds.

I. Commercial Life Insurance. - Life insurance in the United States existed only on a minor scale before 1840.493 Occasionally eighteenth-century marine insurance firms wrote short-term life policies known as "ransom" policies for traveling merchants or ship captains. ${ }^{494}$ And at the close of the eighteenth century, the Insurance Company of North America, which mostly wrote fire and marine policies, experimented with a line of life policies. ${ }^{495}$ But there appears to have been little demand for life insurance in the eighteenth and early nineteenth centuries. The Insurance Company of North America

490 See ERIC HOPKINS, WORKING-ClaSS SELF-HELP IN NINETEENTH-CENTURY ENGLAND: RESPONSES TO INDUSTRIALIZATION 9-IO (I995).

491 See STALSON, supra note 469, at 447; WILENTZ, supra note I44, at 220-2 7; James M. Lynch, Trade Union Sickness Insurance, 4 AM. LAB. LEGIS. REV. 82, 82-83 (I9I4). For a discussion of the status of the Ancient Order of United Workmen as the "first" fraternal organization, see RICHARD DE RAISMES KIP, FRATERNAL LIFE INSURANCE IN AMERICA 32-35 (I 953).

492 See HENRY HANSMANN, THE OWNERSHIP OF ENTERPRISE 265-86 (i 996 ).

493 See Morton Keller, The Life InsuranCE ENTERPRISE, I885-I9Io: A STUDY IN THE LIMITS OF CORPORATE POWER 6 (I 963 ).

494 See STALSON, supra note 469 , at 44 . "Ransom" policies were so named because they were said to have evolved out of the practice among ship captains of putting funds on deposit for use as ransom money in case of capture by Mediterranean pirates. W.A. Hutcheson, The Evolution of Life Insurance, in I READINGS IN LIFE INSURANCE: A COMPENDIUM I, 7 (I934).

495 Viviana A. Rotman Zelizer, Morals and Markets: The Development of Life INSURANCE IN THE UNITED STATES 3 (I979). 
wrote no more than a half-dozen policies in the first four years of the experiment and ended the experiment entirely in 1817.496

In the I840s, however, a boom in life insurance firms produced such future industry giants as New York Life and the Mutual of New York. ${ }^{497}$ The years immediately following the Civil War witnessed still sharper growth in new life insurance enterprises. Between 1865 and I870, no fewer than 107 life insurance firms were established. The number of companies operating in New York alone increased from I4 in 1860 to 69 in 1870.498 Over the same decade, the number of life insurance policies in force in the United States grew from 50,000 to 650,000 , and the value of those policies in force rose from $\$ 140$ million to $\$$ I. 8 billion. 499

The extraordinary growth of the life insurance market slowed during the I870s. A sharp recession in the middle of the decade, questionable actuarial practices, and puffery by unscrupulous sales agents left a number of companies in precarious financial positions and gave many policyholders unrealistic premium expectations. At least eighty insurance companies failed during the decade. ${ }^{500}$ The remaining firms raised premium rates to stay afloat, resulting in the exit of many healthy, low-risk policyholders from the market. ${ }^{001}$ From I875 to I 880 , the number of outstanding life insurance policies had dropped twenty percent, representing a twenty-three percent drop in the total dollar value of all life insurance policies in force. By 1885 , however, the losses of the I870s had been erased. The decades following I885 witnessed a pattern of uninterrupted growth, especially for policyholder-owned mutual companies, which outperformed shareholderowned insurance companies into the twentieth century. ${ }^{502}$

Despite strong growth in the mid-to-late nineteenth century, commercial life insurance firms did not develop an insurance product marketable to the class of Americans most subject to the vicissitudes of the new industrial economy. In the early years of commercial life insurance, firms sold policies almost exclusively to the upper and uppermiddle classes. ${ }^{503}$ The marketing of commercial life insurance to families and individuals of lesser means was not theoretically impossible, but accurate actuarial tables were more difficult to draw up for

496 Id.

497 See KELLER, supra note 493, at 6-7.

498 Id. at 8.

499 Id.

$500: \rightarrow$ Walter C. Wright, Life Insurance in the United States, I PUBLICATIONS AM. STAT. ASS'N I 27, I30 (1888).

$\rightarrow$ Id.

502 See STALSON, supra note 469 , at $40 \mathrm{I}-543$. For a discussion of the distinction between the mutuals and the shareholder-owned firms, see HANSMANN, supra note 492, at 265-86.

503 See KIP, supra note 49I, at 26-2 7; STALSON, supra note 469, at 445. 
workingmen, especially those employed in industries in which accident rates were in flux. Moreover, per-policy profit margins were greater on larger policies, for which administrative costs were relatively low. ${ }^{504}$ As a result, even though it does not appear that commercial companies affirmatively rejected applications because they were for small amounts, ${ }^{505}$ commercial firms did little to attract such applications. Instead, life insurance firms sought out the high-end of the market, particularly after the debacles of the I870s. As Richard McCurdy of the Mutual Life Insurance Company of New York announced in I898, life insurance companies were not "the custodian[s] of the savings of those of slender resources but thrifty habits."506 Instead, they were "the bulwark and defense of large fortunes and large ventures." 507

2. Commercial Accident Insurance. - Commercial insurance markets also offered limited forms of disability and accident insurance. In I 849 the British Railway Passengers' Assurance Company of London began writing insurance for passengers against losses from railway accidents, so-called "accident ticket" policies. ${ }^{508}$ And in the 1850 , a number of small accident insurance firms sprang up in Massachusetts to offer similar policies. ${ }^{509}$ Only in 1864 , however, with the establishment of the Travelers' Insurance Company of Hartford, did American companies begin to write accident policies in significant numbers. ${ }^{510}$ Even as late as 1875 , only three companies were engaged in the accident insurance business in New York State. ${ }^{511}$

Although the accident insurance market experienced strong growth in the thirty years or so after 1875 , this growth did not increase workers' access to accident insurance. By I9Io there was \$18 million in accident insurance in force in the United States. ${ }^{512}$ The largest share of personal accident insurance, however, was sold not to the industrial workers who faced the greatest risk of accidents, but rather to the business and professional classes to protect against accidents in travel..$^{513}$ Indeed, most firms refused to sell policies to individuals working in hazardous occupations such as mining, railroads, iron and

504 In the words of the leading historian of life insurance marketing, the commercial companies "neglected" and "badly treated" the market for less expensive policies. STALSON, supra note 469, at 463.

505 See id.

506 KELLER, supra note 493 , at 52 (internal quotation marks omitted).

507 Id. (internal quotation marks omitted).

508 See W.A. Dinsdale, HistoRy OF ACCIDENT INSURANCE IN GREAT BRITAIN 52-58 (I954).

509 MCNEILL, supra note 286 , at I 2-I 5 .

510 See Crobaugh \& RedDING, supra note 32 I, at 28; James R. Pitcher, Accidents and Accident Insurance, FORUM, Sept. I89I-Feb. I892, at $\mathrm{I} 33$.

511 CROBAUGH \& REDDING, supra note $32 \mathrm{I}$, at 28.

512 Id.

513 Id. at 3 I. 
steel works, lumber, and bridge building, as well as a host of less prominent but still dangerous trades. ${ }^{514}$

\section{FiguRE i. OCCUPATIONS EXCLUDED FROM COMMERCIAL ACCIDENT INSURANCE*}

\begin{tabular}{|ll}
\hline Acid works employee & Gang sawyer \\
Acrobatic performer & Glass work employee \\
Aeronaut & Glucose works employee \\
Army officer in field service & Gravity railroad employee \\
Artesian well borer & Hide and skin worker \\
Band sawyer & Horse railroad employee \\
Barb wire worker & Indian agent \\
Barge man & Iron and steel worker \\
Bark peeler & Lumberman \\
Baseball player, professional & Miner, coal, gold, silver, \\
Brass founder & quartz, or copper \\
Bridge builder, putting up & Moulding machine worker \\
Buzz planer or sawyer & Nail maker \\
Canal boatman & Oil man \\
Captain or mate of coasting & Percussion-cap maker \\
or seagoing vessel & Pulp mill employee \\
Cartridge maker & Quartz mill employee \\
Celluloid worker & Railroad employee \\
Chain maker & Roofer \\
Charcoal burner & Sailor \\
Cider-man or snapper & Scythe maker \\
Circular sawyer & Shingle maker \\
Circus rider & Slater \\
Coal heaver & Slate quarrier \\
Coke drawer or charger & Soap boiler \\
Cutlery forger, hot drop & Spindle maker \\
Cutlery grinder or polisher & Spindle grinder \\
Electric light employee & Stove maker or worker \\
Engineer or fireman of river, & Submarine driver \\
lake, sound, or tugboat & Tack maker \\
Engineer or fireman, seagoing vessel & Telegraph builder or repairer \\
Fibre manufacturer & Thresher, with machine \\
File maker & Varnish maker \\
Fireman & Vitriol maker \\
Firework maker & Wire maker \\
Furniture factory employee & \\
\hline
\end{tabular}

* Katharine Pearson Woods, Accidents in Factories and Elsewhere, 4 PUBlications Am. Stat. Ass'N I, 308-09 (1895).

514 See the accompanying chart in the text. See also MCNEILL, supra note 286, at 102. 
Those accident insurance firms that did write accident policies on railroad employees, such as the notorious Provident Life Insurance \& Investment Company, soon found themselves swamped with claims. ${ }^{515}$ The Provident quickly went out of business, but only after it tried to fend off railway workers' claims through what one observer called "litigation of the most pettifogging description." 516

The exclusion of railway and other dangerous occupations from accident policies was one manifestation of commercial accident insurance companies' preoccupation with the problems of adverse selection and moral hazard. ${ }^{517}$ Accident insurance policies typically disclaimed coverage for accidents caused by "voluntary exposure to unnecessary danger,"518 "the influence of intoxicating drinks," 519 the violation of any laws, ${ }^{520}$ voluntary overexertion, ${ }^{521}$ the failure to use "due diligence for ... personal safety," ${ }^{22}$ and countless other specific hazards. ${ }^{523}$ Companies required applicants to warrant that they were in good health and in possession of full use of their faculties and that their "habits of life [were] correct and temperate." 524

In short, accident insurance policies reproduced much of the doctrine of contributory negligence from the still-developing common law of torts. Moreover, to solve the difficult problems of proof in disability insurance markets, almost all accident policies covered only accidents causing "external and visible" marks. ${ }^{525}$

As a result of these exclusions, commercial accident policies covered only a small portion of the accidents that caused individuals to seek disability insurance in the first place. Moreover, despite the ex-

515 See Accident Insurance, 7 AM. L. REV. 585, 597-98 (I873). For accounts of the early difficulties of accident insurance companies, see CROBAUGH \& REDDING, supra note 32 I, at 29 (describing the inexperience of the early companies and their difficulties in mastering the "many varying factors, the control of which rested with the assured, such as moral qualities, cooperation in the treatment, and so forth, which greatly influenced the business"); and MCNEILL, supra note 286, at 9 (describing the susceptibility of early accident insurance companies to fraudulent claims).

516 Accident Insurance, supra note 5 I5, at 598. For railway worker cases involving the ill-fated Provident, see Providence Life Ins. \& Inv. Co. v. Martin, 32 Md. 3 10 (1869); and Perry v. Provident Life Ins. \& Inv. Co., 99 Mass. 162 (1868).

517 For comment on the nineteenth-century practice of refusing to insure moral hazards rather than simply increasing their premiums, see Baker, supra note 483 , at 252-55.

518 Accident Insurance, 48 CENT. L.J. 280, 280 (I896); see also Accident Insurance, 3 U.L. REV. 264, 264 ( (1897).

519 Accident Insurance, 3 CENT. L.J. 65 I, 65 I-52 (1876).

520 See, e.g., Hubert BRUCE Fuller, The LAW OF ACCIDENT AND EMPlOyerS' Liability INSURANCE I 28-4I (I9I3); MCNEILL, supra note 286, at 98.

521 MCNEILL, supra note 286 , at 98.

522 FULLER, supra note 520, at 260 ; see MCNEILL, supra note 286, at 100.

523 See generally FULLER, supra note 520, at 87-288 (including, inter alia, injuries sustained on a railroad bed or bridge and those sustained from inhaling gas; entering, leaving, or standing on moving cars; bodily infirmities; and disease); MCNEILL, supra note 286 , at 98-100.

524 MCNEILL, supra note 286 , at 100.

525 FULLER, supra note 520, at II9-28. 
tensive use of disclaimers and exclusions, accident insurance companies faced enormous problems of policing for moral hazard after covered injuries occurred, as well as for outright fraud. The Massachusetts Mutual Accident Insurance Association, for example, reported "great costs" arising from "fraudulent and fictitious claims." 26 Massachusetts Mutual's treasurer noted that claimants sought to deceive insurers as to the date of the injury, the duration of the disability, and the existence of preexisting conditions. ${ }^{527}$ According to another insurance industry observer, there were simply too many "varying factors," such as the "moral qualities" of the insured and his "cooperation in the treatment," that "greatly influenced the business" and yet were often beyond the control of the insurer. ${ }^{528}$ Indeed, the problems of moral hazard and adverse selection led to a kind of macabre humor among insurance company executives. Samuel Clemens (better known as Mark Twain), who served as a director of the Hartford Accident Insurance Company in the I87os, suggested darkly in one insurance convention after-dinner speech that an insurance company such as the Hartford was "an institution which is peculiarly to be depended on. ... No man can take out a policy in it and not get crippled before the year is out." 529 Sure enough, the Hartford failed later that year. ${ }^{530}$

3. Industrial Insurance. - Because of the commercial accident insurance companies' inability to address effectively the problems facing disability insurance markets, commercial accident insurance in the late nineteenth century never expanded beyond the narrow market of traveling businessmen and professionals. In contrast, marketing efforts in what became known as "industrial" insurance were aimed squarely at working-class families. ${ }^{531}$ Industrial insurance consisted of small life insurance policies paid for by weekly premiums of as little as five cents, collected by insurance agents who went door to door on payday. Though the Prudential Assurance Company had offered industrial policies in England since I854, the first company to offer industrial insurance in the United States, the Prudential Insurance Company of America (then the Prudential Friendly Society), began writing policies only in 1875.532 The Metropolitan Life Insurance Company and the John Hancock Mutual Life Insurance Company soon joined the field, and in the last decades of the nineteenth century, industrial insurance

526 MCNEILL, supra note 286, at 105.

527 Id. at I05-09.

528 CROBAUGH \& REDDING, supra note $32 \mathrm{I}$, at 29.

529 Mark Twain, Speech at the Hartford Accident Insurance Company, Hartford, Conn. (Oct. I 2, I874), in MARK TWAIN SPEAKING 89, 9i (Paul Fatout ed., I976).

530 GOODMAN, supra note 396, at $9 \mathrm{r}$ (1998).

531 MALVIN E. DAVIS, INDUSTRIAL LIFE INSURANCE IN THE UNITED STATES 3 (I944).

532 Id. at 3-24. 
grew at a rapid pace. In I 880 there was approximately $\$ 20$ million of industrial insurance in force in the United States, representing 228,357 policies, or one policy for every 217 Americans. ${ }^{53}$ By 1900 there was almost \$I.5 billion in force, representing approximately eleven million policies, or one policy for every seven Americans. ${ }^{534}$

Industrial insurance policies, however, were purchased by working families not so much to replace earnings or to sustain a family after the death of a wage-earner as to pay for the costs of burial. The average industrial insurance policy provided families with no more than enough to pay for funeral costs - typically "about $\$ 100$ for adults and $\$ 50$ for children" 535 - an amount hardly sufficient to sustain the families of disabled wage-earners. As one early twentieth-century student of urban working-class families observed, industrial insurance was "more properly described as burial-insurance than as lifeinsurance." 536 Families thus purchased policies not just for wageearners, but also for wives who worked in the home, as well as for children. ${ }^{537}$ Indeed, by the early twentieth century, women outnumbered men among industrial policyholders. Children under five, moreover, represented the single largest age cohort. ${ }^{538}$ Industrial insurance, then, functioned only as an insurance policy against a narrow subset of the costs of deaths from accident, sickness, or old age.

4. Trade Union Insurance Plans. - Some Americans in the late nineteenth century were able to acquire insurance against death and disability through trade unions. When German economist August Sartorius von Waltershausen toured the United States in the mid-I880s, he found that the recession of the 1870 s had decimated union membership levels. ${ }^{539}$ In response, he observed, many American labor leaders in the 1880 s had begun to use union benefit funds to bolster members' loyalty to the trade union system. ${ }^{540}$ As Waltershausen noted, however, such benefit funds had not had great success. ${ }^{541}$

In one sense, this lack of success is somewhat surprising. Trade union funds were well positioned to overcome the moral hazard and adverse selection problems that plagued commercial accident insur-

\footnotetext{
533 See STALSON, supra note 469 , at 809.

534 Id.

535 ROBERT COIT CHAPIN, THE STANDARD OF LIVING AMONG WORKINGMEN'S FAMILIES IN New YORK CITY I9I (I909); see also CHARLES RICHMOND HENDERSON, INDUSTRIAL INSURANCE IN THE UNITED STATES I 50 (I909) (estimating the average policy value in I899 at slightly more than \$IOO).

536 CHAPIN, supra note 535, at I9I.

537 See MAURICE TAYlOR, The SOCIAL COST OF INDUSTRIAL INSURANCE 54-55 (I 933).

538 Id. at 55-56.

539 WALTERSHAUSEN, supra note 86 , at 197.

$540 \mathrm{Id}$

541 See id. at 198.
} 
ance companies. Union locals fostered commitment and loyalty among their members, and the intimacy of members' face-to-face relationships allowed them to monitor one another's claims. The few trade union disability and death benefit plans that were successful worked hard to prevent the exit of low-risk members from insurance pools, as well as to combat malingering and fraudulent claims. Membership in such union funds was compulsory for all union members. ${ }^{542}$ Moreover, the few union benefit plans that became widespread in the latter part of the century included benefit disclaimers for injuries arising out of immoral or unnecessarily dangerous activities. ${ }^{543}$ Union benefit plans also implemented formal visiting committees whose roles were partially social and partially monitoring. Typically, a union appointed a committee of at least two members to visit a disabled fellow member; no two members of the committee were to visit at the same time, and each member was to report independently to the union on the disabled member's condition. ${ }^{544}$

Moreover, the trade unions seemed like the natural home for cooperative associations for the mutual protection of workingmen against the new industrial accident problem. If work accidents threatened the ideals of free labor citizenship, it would appear logical for the same trade unions that sought to sustain the dignity and independence of wage-earners in the workplace to have adopted cooperative mechanisms designed to protect against the effects of industrial accidents.

Trade unions, however, faced a difficult dilemma. Unions' interest in broadening their organizational base inhibited the widespread development of accident relief funds in the late nineteenth century. Relief funds could encourage loyalty to the union in tough times, ${ }^{545}$ but they also raised the cost of trade union membership. Furthermore, effective administration of the trade union insurance funds required the expulsion of members who failed to pay their insurance dues. Thus, by 1860 , it became a "well accepted doctrine that a trade union should not attempt to develop benevolent functions" because of the possibility of creating a drag on union membership. ${ }^{546}$ Prior to the 1880 , only a few national trade unions created funds insuring against disability and death. Indeed, in the r86os and I870s, only the railway brotherhoods,

\footnotetext{
542 See James B. Kennedy, Beneficiary features of American Trade Unions 9-10 (Johns Hopkins Univ. Stud. in Historical \& Political Sci., Series 26, Nos. I I-I 2, I 908).

54323 ANN. REP. COMM'R OF LABOR: WORKMEN'S INS. \& BENEFIT FUNDS IN THE U.S. 29-30 (I909) [hereinafter ANN. REP. COMM'R OF LABOR].

544 Id. at 29.

545 Id. at 23.

546 KENNEDY, supra note 542, at 9-10.
} 
for which the industrial accident problem was especially acute, established widespread union-based mutual insurance funds. ${ }^{547}$

A few nonrailway unions established insurance funds in the years immediately following the Civil War. The Cigar Makers' Union created a death benefit program in 1867 , as did the Iron Molders' Union in 1870 and the Granite Cutters' Union in 1877 . After 1880 a number of trade unions established similar death benefit programs; by I904, 53 of II 7 national unions affiliated with the American Federation of Labor provided death benefits for their membership. ${ }^{548}$ Nonetheless, in all of these nonrailway union programs, the death benefit seldom exceeded the cost of burial. "The ordinary death benefit in American trade unions," wrote one early twentieth-century student of union benefit programs, was only "a sum assumed to be sufficient to inter decently the deceased." 549 Thus trade union death benefits at the turn of the century closely resembled industrial insurance policy benefits, ranging from $\$ 50$ to $\$ 200$ depending on the union and the duration of the deceased's membership. ${ }^{550}$

Disability benefits - labeled "sick benefits," but payable for any disability preventing the member from working - were considerably less common than death benefits among nonrailway trades unions. ${ }^{551}$ From the late I860s onward, a number of local union lodges sought to create formal disability insurance funds. ${ }^{552}$ Only in the I880s, however, did national trade unions begin to offer formal disability benefits on a widespread basis; by r 904 less than a quarter of AFL trades unions offered such benefits. ${ }^{553}$ Most trade unions resisted the introduction of disability benefits, usually because of the great difficulty of administering disability, as opposed to death, benefits. It was significantly more difficult to verify disability claims than death claims. Moreover, disability benefits forced unions into the messy business of policing claims to determine whether a member qualified as disabled.

By contrast, railway brotherhoods offered their members substantially larger life insurance benefits, as well as sizeable permanent dis-

\footnotetext{
547 Id.
}

54824 PRoceEdings of the ANNUAL Convention OF THE AMERICAN FEderation OF LABOR 46 (I904).

549 KENNEDY, supra note 542 , at 53 n.I 2 .

$550 I d$. at 54-56. Like industrial insurance, trade union insurance often featured similar death benefits for members' wives and children. Id.

551 Fifty of eighty-four union benefit plans surveyed by the U.S. Commissioner of Labor in I908 offered death benefits but not temporary or permanent disability benefits. See 23 ANN. REP. COMM'R OF LABOR, supra note 543, at 36-39.

552 See, e.g., CONSTITUTION AND BY-LAWS OF THE BRICKLAYERS' AND Plasterers' Benevolent and Protective Union (New Haven, Pettle, Morehouse \& Taylor i868) [hereinafter BRICKLAYERS' \& Plasterers' CONSTITUtion \& BY-LAWS].

553 KENNEDY, supra note 542 , at 72 . 
ability benefits. Railway brotherhoods borrowed heavily from the cooperative insurance movement, adopting its ritualistic fraternal features and its lodge-based model of organization. ${ }^{554}$ Also like many of the cooperatives, the railway brotherhoods conceived their role as primarily addressing the industrial accident problem. Indeed, students of the railway brotherhood benefit funds understood them to respond directly to the liability regime for railroad work accidents. One leading student of the railway benefit funds observed that risk in railroad employment resulted from at least three sources: "the nature of the trade, the negligence of a fellow workman, or the negligence of the employers." 555 Under the common law of employers' liability, however, compensation was available at law only in the third class of accidents. The railway employee was therefore required to make provisions on his own against the other two kinds of accidents, and railway brotherhoods became the leading mechanism for self-insurance against these kinds of accidents. ${ }^{556}$

The railroad troubles of the 1890 and the recession that began in I 893 took serious tolls on railway union membership. Nonetheless, in the middle of the first decade of the twentieth century, railway brotherhood insurance remained the leading form of railroad worker insurance against death and disability from accidents. ${ }^{557}$ Indeed, the leading railway brotherhoods had a combined membership of more than one quarter million, representing as many as one in four railroad workers. ${ }^{558}$ In the first decade of the twentieth century, the seven great railway brotherhoods - the Brotherhood of Locomotive Firemen, the Grand Brotherhood of Locomotive Engineers, the Order of Railway Conductors of America, the Switchmen's Union of North America, the Brotherhood of Railway Trainmen, the Order of Railway Telegraphers, and the International Brotherhood of Maintenance-ofWay Employees ${ }^{559}$ - distributed more than $\$ 4$ million in death benefits each year to their memberships, as well as over one half million in permanent disability benefits. ${ }^{560}$ Typical railway brotherhood death

554 Edwin Clyde Robbins, Railway Conductors: A Study in ORganized Labor 20 (Colum. U. Stud. in Hist., Econ. \& L., No. I48, I9I4); Joel IsAaC SEIDMAN, THE Brotherhood OF RAILROAD TRAINMEN: THE INTERNAL POLITICAL LIFE OF A NATIONAL UNION 2-5 (I962).

555 KENNEDY, supra note 542, at 49.

556 Id. at 49.

557 See Emory R. Johnson, Railway Relief Departments, in 8 BULL. DEP'T OF LABOR 39, 39 (Washington, D.C., Gov't Printing Office I897).

558 For a discussion of the membership numbers, see KENNEDY, supra note 542, at $20-29$ (author's notes). For the total numbers of railroad workers in the late nineteenth and early twentieth century, see I HISTORICAL STATISTICS OF THE UNITED STATES, supra note 175, at I 39 (I975).

559 For a discussion of the seven great railway brotherhoods, see KENNEDY, supra note $54^{2}$, at I9 (author's notes).

56023 ANN. REP. COMM'R OF LABOR, supra note 543 , at 48, 50. 
benefits ranged from $\$ 1000$ to $\$ 3000^{561}$ and often reached as high as $\$ 4500.562$ The brotherhoods paid permanent disability benefits in similar amounts, usually in place of death benefits. ${ }^{563}$ In 1893 the railway brotherhoods even set up a Home for the Aged and Disabled Railroad Employees of America in Highland Park, Illinois, "to aid such who, by accident or from other causes, are permanently incapacitated for railroad work." 564

In at least some instances, a sophisticated theoretical foundation accompanied the successes of the trade union benefit funds. Losses in membership during the recessions of the 1870 - and again in the r 890 s - caused a number of union leaders to advocate union benefit funds as a way to promote commitment to the union in hard times. ${ }^{565}$ According to the editors of the German-language labor newspaper New-Yorker Gewerkschafts-Zeitung, for example, union funds "impose[d] a highly necessary discipline on the members" and "feelings of solidarity and fraternity." 566 Most of all, however, union relief funds offered a means of forcing employers to pay the costs of accidents, notwithstanding the narrow employers' liability rules of the common law. As the editors of the Gewerkschafts-Zeitung observed, Marx contended that wages equaled the subsistence cost of reproducing the workforce. Such subsistence costs, however, were socially constructed, and thus wages "depend[ed] on the needs, habits, and expectations of a country's workers." 567 Over time, the editors argued, payments into a union relief fund would "heighten expectations," which in turn (on Marx's theory) would result in higher wages. At the very least, the increased union solidarity fostered by the relief funds would increase the union's bargaining power and thus increase wages. ${ }^{568}$ "So it is already in our power," the editors concluded (too optimistically, no doubt), "to make the employers financially liable for the care of their victims." $\$ 69$

\footnotetext{
561 Id. at 78 .

562 KENNEDY, supra note 542 , at $4 \mathrm{I}$.

56323 ANN. REP. COMM'R OF LABOR, supra note 543 , at 32.

564 Id. at 79 .

565 See KENNEDY, supra note 542, at 5 I; WALTERSHAUSEN, supra note 86, at 197.

566 WALTERSHAUSEN, supra note 86 , at 197.
}

$567 I d$. at I 98 . The editors very likely referred to the passage in which Marx argued that wages were set according to the labor time necessary to sustain and reproduce the workforce but observed that the minimum necessities of any given workforce are themselves inevitably "products of history, and depend therefore ... on the habits and expectations with which, the class of free workers has been formed." I KARL MARX, CAPITAL 275 (Ben Fowkes trans., Penguin Books 1990) (I867).

568 WALTERSHAUSEN, supra note 86 , at 198.

569 Id. This Marxian theory of charging employers "for the care of their victims" via increases in wage levels resembles in certain respects the contemporary law and economics theory that parties to contracts will freely contract around liability rules so long as transaction costs are sufficiently low, see R.H. Coase, The Problem of Social Cost, 3 J.L. \& ECON. I (I960). The Marxian approach, 
Notwithstanding this general theoretical basis for union relief funds, union insurance for more than funeral expenses ultimately remained uncommon outside the railway brotherhoods. The geographical mobility of American workers and the frequency with which they changed trades presented significant problems for trade union accident insurance. Waltershausen, the German economist who toured the United States in the mid-r 880 os, observed that few workers wished to invest money in funds from which they were likely to depart before they received benefits. ${ }^{570}$ Moreover, trade union funds posed a special problem in hard times for specific industries; if the construction industry, for example, went into a particularly entrenched recession, members would face great difficulty making dues payments, and building trades unions would be hard pressed to pay benefits. Finally, unions experienced continuing tension between the competing goals of fostering loyalty among existing members and expanding union membership among unorganized workers. After long service as secretary-treasurer of the Brotherhood of Locomotive Firemen and editor of the Brotherhood's Locomotive Firemen's Magazine, Eugene V. Debs resigned from his leadership of the Brotherhood in 1892 because he opposed its insurance functions. "An order of this kind should be divorced from an insurance company," Debs announced to the Firemen's convention, "as thousands of men are expelled because they cannot maintain that branch of the order." 571 Because of similar qualms, the Knights of Labor included a mutual insurance program in their constitution but never implemented it. ${ }^{572}$

What American workingmen needed, then, was an insurance mechanism that took advantage of the trade union's singular capacity to police for moral hazard and adverse selection, but that was institutionally distinct from trade unions so as not to create tensions between organizing and insuring. Moreover, such an insurance mechanism ideally would not be tied to employment in any particular trade or establishment and would allow for geographical mobility. Cooperative insurance societies provided just such a system of insurance.

\footnotetext{
however, goes one step beyond the law and economics theory to posit an account of the construction of the parties' preferences.

570 See WALTERSHAUSEN, supra note 86, at 198-99. As Waltershausen noted, this fact posed less of a problem for protection against sickness and injury, in which rates reflected ongoing risks, than it did for life insurance, in which premiums might include payment toward a higher risk of death in the future. See id. at I99. Even for accident or sickness insurance, however, many union funds determined a member's dues by reference to his age of entry. Departure from such funds after the passage of a period of time acted as a forfeiture of the benefit of a lower rate.

571 SALVATORE, supra note I83, at I 12.

572 See TerenCe V. POWDERLy, Thirty YeARS OF LABOR: I859 TO I889, at 453 (Columbus, Ohio, Rankin \& O’Neal I89o).
} 


\section{CoOperative Self-INSURANCE AND THE CoOperative CRITIQUE OF INDUSTRIAL ACCIDENTS}

Cooperative insurance associations developed and flourished where other forms of insurance in the late nineteenth century struggled. This success was due, at least in part, to the remarkable methods that cooperatives developed to address the perennial problems of disability insurance markets. In this respect, cooperative life and disability insurance resembled the many varieties of mutual insurance against contingencies such as fire and maritime disaster that had developed among farmers and merchants in the eighteenth and nineteenth centuries. ${ }^{573}$ In addition, the success of the cooperatives reflected their attempt to preserve and reestablish mid-century free labor ideals in a rapidly changing economy. If industrial accidents stood as the starkest embodiment of the threat to free labor ideals posed by the new wageearning industrial economy, then the insurance societies, in turn, formed the leading wedge of a late nineteenth-century cooperative movement that advocated the transformation of America's competitive capitalist economy into a cooperative commonwealth.

\section{A. Cooperative Associations as Accident Insurance Mechanism}

I. The Incidence of Cooperative Insurance. - Even though American cooperative insurance associations emerged only after the Civil War, in a short twenty years cooperative life and disability insurance rivaled commercial life insurance in size. By I885 the almost $\$ 2$ billion of insurance in force that cooperative associations reported to state insurance officials represented just under half of all life insurance in force in the United States. ${ }^{574}$ 


\section{TABLE 3. INSURANCE IN FORCE IN THE UNITED STATES, I875-I910*}

\begin{tabular}{|l|l|l|l|l||}
\hline & \multicolumn{2}{|c|}{ Cooperatives } & \multicolumn{2}{c|}{ Commercial Life Companies } \\
\hline Year & Certificates & $\begin{array}{l}\text { Amount (millions of } \\
\text { dollars) (nonindexed) }\end{array}$ & Policies & $\begin{array}{l}\text { Amount (millions of } \\
\text { dollars) (nonindexed) }\end{array}$ \\
\hline $\mathrm{I} 875$ & & & 774,625 & $\$ \mathrm{I} 922$ \\
\hline $\mathrm{I} 880$ & & & $608,68 \mathrm{I}$ & $\mathrm{I} 476$ \\
\hline $\mathrm{I} 885$ & & $\$ \mathrm{I} 969$ & $8 \mathrm{I} 4,69 \mathrm{I}$ & 2024 \\
\hline $\mathrm{I} 890$ & & 3659 & $\mathrm{I}, 272,895$ & 3543 \\
\hline $\mathrm{I} 895$ & & 6589 & $\mathrm{I}, 877,808$ & $48 \mathrm{I} 8$ \\
\hline $\mathrm{I} 900$ & $4, \mathrm{II}, 848$ & 7580 & $3,07 \mathrm{I}, 253$ & 6947 \\
\hline $\mathrm{I} 905$ & $6, \mathrm{II} 8,938$ & $\mathrm{I0,412}$ & $5,306, \mathrm{IO} \mathrm{I}$ & $\mathrm{I0,554}$ \\
\hline $\mathrm{I} 910$ & $8,558,093$ & $\mathrm{I} 2,394$ & $6,050,6 \mathrm{I} 7$ & $\mathrm{II}, 670$ \\
\hline
\end{tabular}

* J. OWEN STAlson, MARKeting LIFE INSURANCE: ITS History IN AMERICA 80607, 8I7-I9 (I942); 72 ANN. REP. SUPERINTENDENT OF THE INS. DEP'T OF THE STATE OF N.Y., pt. II, at xxiii (I93I). ${ }^{575}$

By 1890 the quickly growing cooperative insurance movement had become the leading source of life insurance in the United States. By I895 fraternal and other cooperative insurance associations reported $\$ 6.6$ billion of life insurance in force, an amount substantially greater than the total life insurance in force through commercial companies mutual and stock companies combined. ${ }^{576}$

Throughout this period, the number of persons insured through cooperative insurance associations appears to have exceeded the number of persons insured by commercial life companies. There are no accurate figures for the total number of fraternal and cooperative insurance association members prior to $1900,{ }^{577}$ but by that year fraternal and cooperative societies reported over four million certificate holders, compared to just over three million policy holders in commercial com-

575 Stalson estimates that his figures underreport the total fraternal insurance in force by at least twenty percent. STALSON, supra note 469 , at 806 . The chart in the text above reflects Stalson's figures adjusted by his twenty percent estimate. It should be noted that Stalson divides cooperative insurance enterprises into "fraternal societies," which made up the overwhelming share of the cooperative insurance in force throughout the period, and "assessment societies," which represented roughly one tenth of the cooperative life insurance market. For the assessment societies, Stalson's statistics begin only in 1899 . See id. at 806-07.

$576 \mathrm{Id}$. at $8 \mathrm{I} 9$. This $\$ 6.6$ billion figure accounts for Stalson's estimate of twenty percent underreporting by fraternal societies.

577 See, e.g., KIP, supra note 49I, at I5 (beginning a count of the number of outstanding fraternal certificates in 1904); STALSON, supra note 469 , at 807-08 (beginning a count of the number of outstanding fraternal certificates in 1899 ). State insurance reports provide only a partial state-by-state picture of fraternal insurance association membership before the turn of the century. 
panies. ${ }^{578}$ Over the next ten years, the number of fraternal certificate holders doubled to well over eight million. ${ }^{579}$

Yet the reported statistics surely underestimate the total number of Americans who participated in cooperative insurance associations. Reported statistics generally reflected the activities of the large, national insurance cooperatives. But many cooperatives were organized informally on a purely local basis. By the mid-I89os, it became a commonplace among insurance experts that the cooperative insurance system was as much as twice the size of its commercial competition..$^{580}$ Moreover, careful studies of the populations of eastern states revealed that although the cooperative insurance data reported to state insurance commissioners indicated that one in fifteen Americans belonged to a cooperative insurance society, ${ }^{581}$ actual membership levels (including the smaller, local associations) were larger still. In Connecticut, for example, a study published in I89I by the state Bureau of Labor Statistics found that more than one in six residents of the state belonged to a cooperative insurance society. ${ }^{582}$ Given that the membership in these societies was virtually all male, ${ }^{583}$ it seems fair to say that perhaps one half of the adult men in Connecticut belonged to an insurance association. ${ }^{584}$ Among the residents of towns and cities, the figures appear to have been even higher. In New Haven, one in four residents belonged to a cooperative insurance association; in Danbury, the famous hat-making town, and Meriden, a small industrial city on the Connecticut River, cooperative insurance association membership was closer to one in three. ${ }^{585}$

2. Cooperative Life and Disability Benefits. - Cooperative associations provided a wide range of benefit levels. Many of the small, local mutual insurance societies appear to have offered only minimal life insurance benefits and little in the way of disability benefits. As

578 See 72 ANN. REP. SUPERINTENDENT OF THE INS. DEP'T OF THE STATE OF N.Y., pt. II, at xxiii (I93I) [hereinafter ANN. REP. N.Y. SUPERINTENDENT].

579 Id.; see also KIP, supra note 49I, at 15 (estimating 6.5 million members in I9Io). Life insurance company policyholder numbers kept pace, doubling to over six million by rgro. See ANN. REP. N.Y. SUPERINTENDENT, supra note 578 , at xxiii.

580 See Insurance Law as a Specialty, 2 YALE L.J. I45, I45 (I893) (attributed to "a Member of the New York Bar").

581 Meyer, supra note $47 \mathrm{I}$, at 647 .

582 See 7 ANN. ReP. Bureau of Labor Stat. of the State of CONN. FOR the Year ENDING NoV. 30, I89I, at II3 (Hartford, Fowler \& Miller Co. I892) [hereinafter CoNNECTICUT REPORT].

583 The study found that $\mathrm{I} 18,6 \mathrm{I} 3 \mathrm{3}$ of $\mathrm{I} 26,6 \mathrm{I} 33$ members were men. Id . at 68 .

584 David Beito concludes that during the late nineteenth century one in three adult males participated in fraternal cooperative insurance societies nationwide. See David T. Beito, Thy Brother's Keeper: The Mutual Aid Tradition of American Fraternal Orders, 70 POL'Y REV. 55, 56 (1994).

585 See CONNECTICUT REPORT, supra note 582, at Io9, I I I, I I3. 
we shall see, the inability of many of the associations to provide substantial insurance to their members contributed to the decline of the cooperative insurance movement in the first decade of the twentieth century. ${ }^{586}$

The more successful national cooperative associations, however, were able to offer their members disability and life insurance benefits that, although not exactly generous, provided meaningful income replacement in the event of the death or disability of a wage earner. National associations typically offered their members life insurance benefits of $\$ 1000$ or $\$ 2000$, often along with lump-sum permanent disability benefits of one half the life insurance benefit. ${ }^{587}$ In addition, many associations' local lodges offered temporary disability benefits that ranged from two to five dollars per week. ${ }^{588}$ In an era when typical workingmen earned roughly ten dollars per week, such temporary disability benefits represented somewhere between one fifth and one half of weekly wages. ${ }^{589}$

3. The Structure of Cooperative Disability and Life Insurance: Moral Hazard and Adverse Selection. - The rapidly increasing problem of accidents appears to have formed the primary impetus for the development of the postwar cooperative societies. As the members of one New Haven association announced in 1868 , workingmen founded cooperative insurance societies to protect members who became "disabled by reason of accident, at [their] own employment, not caused by [their own] immoral or disorderly conduct." ${ }^{590}$ Working-class men in urban or industrial areas constituted the majority of the cooperative insurance societies' membership. ${ }^{591}$ Contemporary observers uni-

586 See infra pp. 831-33.

587 See, e.g., Hutchinson v. Supreme Tent of Maccabees of the World, 22 N.Y.S. 80I, 80I-04 (Gen. Term I 893) (describing the $\$ 2000$ life insurance benefit and \$1000 permanent disability benefit of the Maccabees of the World); CONNECTICUT REPORT, supra note 582, at I69 (describing the $\$ 1000$ life insurance benefit of the Knights of Columbus); R.C. Hill, The Evolution of an Idea, Fraternal MONITOR, Aug. I, I890, at 2 (author's notes on file with the Harvard Law School Library) (describing the $\$ 2000$ life insurance benefit of the Ancient Order of United Workmen).

A note about The Fraternal Monitor: all issues dated before I 9 I I are available at the New York Public Library, which does not permit photocopying of these fragile volumes. The author's typewritten notes on the issues cited are on file with the Harvard Law School Library.

588 See, e.g., CONNECTICUT REPORT, supra note 582, at I68 (describing the five-dollar per week disability benefits offered through the local lodges of the Knights of Columbus); id. at 23I (describing the two- to five-dollar disability benefits offered through the local lodges of the Ancient Order of United Workmen).

589 See I HISTORICAL STATISTICS OF THE UNITED STATES, supra note I 75, at I68 (estimating average annual wages in manufacturing and railroad occupations in 1890 at $\$ 439$ and $\$ 560$, respectively).

590 BRICKLAYERS' \& Plasterers' CONSTITUTION \& BY-LAWS, supra note 552, at i 2.

591 Most historians of nineteenth-century fraternal associations have emphasized the fraternals' middle-class membership. These studies, however, have been preoccupied with the elite associations of the fraternal world, whose records were often more complete than those of the less well- 
formly remarked on the working-class base of the cooperative benefit societies, whose memberships were composed of "the lower-paid workmen and the well-paid mechanics." 592 Indeed, one Connecticut study found that over sixty percent of mutual insurance society members fit into these two groups. ${ }^{593}$ Cooperative insurance association members predominantly lived in industrial or urban areas. Agricultural associations, such as the Patrons Aid Society of Elmira, New York, occasionally sought to develop mutual insurance associations..$^{594}$ Such associations rarely flourished, however, apparently due to a lack of demand in agricultural settings for the kinds of mutual insurance programs that were sweeping across urban and industrial regions. ${ }^{595}$

Because cooperative insurance associations served a primarily working-class, urban population, they generally provided members with both disability insurance and death benefits. To be sure, a few mutual insurance associations provided only death and funeral benefits, but most offered disability benefits as well. ${ }^{596}$ Indeed, the number of insurance associations offering disability benefits grew steadily through the I870s and I880s, significantly outpacing the growth in pure life insurance associations. ${ }^{597}$

Cooperative insurance societies adopted precisely the kind of disciplinary rules and regulations that one would expect to see in organizations dealing with the moral hazard and adverse selection problems endemic to disability insurance. Cooperative insurance associations

heeled cooperative fraternal insurance associations of the working class. See CARNES, supra note 485, at 3-4 (describing fraternals as a middle-class phenomenon); ClAwSON, supra note 485, at 87I IO (arguing that although the working class participated in fraternals, such organizations were not organs of working-class solidarity); DUMENIL, supra note 485, at 9 (finding the Masonic Order to be primarily composed of the middle class); Daniel Greenberg, Worker and Community: Fraternal Orders in Albany, New York, I845-1885, 8 MD. HISTORIAN 38, 43 (1977) (finding that Odd Fellows membership consisted of the "great middle-industrial classes"); Roy Rosenzweig, Boston Masons, 1900-1935: The Lower Middle Class in a Divided Society, 6 J. VOLUNTARY ACTION RES. I I9, I 24 (I977) (concluding that the membership of the Boston Masons was primarily native-born, white, and middle-class).

592 CONNECTICUT REPORT, supra note 582, at I2; see also 23 ANN. REP. COMM'R OF LABOR, supra note 543 , at I5; HENDERSON, supra note 535, at I I 7 ; WALTERSHAUSEN, supra note 86 , at I 7 I-230.

593 CONNECTICUT REPORT, supra note 582, at I05.

594 See By-LAWS OF THE PATRONS AiD Society i I (Elmira, N.Y., Husbandman Print I876).

595 The Patrons Aid Society complained in $\mathrm{I} 88 \mathrm{I}$ that "[f]armers, as a class, have not yet learned to fully appreciate the importance of providing for their families that ready aid and protection which our Society offers them." SIXTH ANNUAL REPORT OF THE PATRONS AID SOCIETY, ELMIRA, N.Y. 6 (Elmira, N.Y., Husbandman Print I88I); see also CONNECTICUT REPORT, supra note 582 , at 105 (finding that farmers constituted less than one percent of the membership of Connecticut mutual insurance societies).

596 See 23 ANN. REP. COMM'R OF LABOR, supra note 543, at 17-I8; CONNECTICUT REPORT, supra note 582; WALTERSHAUSEN, supra note 86, at I 92, 205-I8.

597 See CONNECTICUT REPORT, supra note 582 , at 85 . 
universally required medical examinations of prospective members, ${ }^{598}$ and virtually all the associations made "[t]horough investigations as to the character of applicants." 599 Members faced expulsion from the associations for making false statements of their age or lying during their medical examinations. ${ }^{600}$ Association bylaws typically provided for the forfeiture of members' rights to relief when "disability [was] superinduced by drunkenness or fighting or other disgraceful practices." 601 Many associations also barred the recovery of death or disability benefits by members who had exposed themselves to "unusual danger." 602 Once a member filed a claim, his fellow members were usually under an obligation to visit and monitor his progress. In many instances, no doubt, members undertook such visits in the spirit of fraternal good will. But it is apparent that visitation requirements also served to identify "suspicious cases." 603 Members claiming benefits faced expulsion and denial of their claims for "evad[ing] supervision by the society," ${ }^{604}$ and visiting committees were obligated to report any irregularities promptly to their association's treasurer. ${ }^{605}$ Delinquency in the payment of assessments or fines for violations of an order's code of behavior - including, in some societies, an injunction against working for less than specified rates in particular trades - could also result in forfeiture of benefits. ${ }^{606}$

Cooperative insurance societies designed their insurance pools to foster group loyalty and mutuality. National cooperative insurance associations such as the Ancient Order of United Workmen organized around local lodges that typically ranged between 50 and I50 members. ${ }^{607}$ The national scale of the pool ensured actuarial stability. The

598 See, e.g., CONSTITUTION OF THE UNIVERSAL WORKMEN'S SiCK \& DEATH BENEFIT Fund OF THE UNITEd States OF North AMERICA 3-4 (New York, John Oehler, Steam Book \& Job Printer I893) [hereinafter SICK \& DEATH BENEFIT FUND]; GENERAL LAWS, RULES AND REGULATIONS OF THE BENEFICIARY DEgREE, JUNIOR ORDFR OF UNITED AMERICAN MECHANICS IO (I905).

599 The Order of the World, FRATERNAL MONITOR, Aug. I, I89o, at I 2 (author's notes).

600 See, e.g., SICK \& DEATH BENEFIT FUND, supra note 598, at 5.

601 Legal Environments, FRATERNAL MONITOR, Oct. I, I89o, at I4 (author's notes).

602 SICK \& DEATH BENEFIT FUND, supra note 598, at 5.

603 Id. at 7 .

604 Id. at 5 .

605 Id. at 7.

606 See People ex rel. Doyle v. N.Y. Benevolent Soc'y of Operative Masons, 6 Thompson \& Cook $85,86-89$ (N.Y. Sup. Ct. I875) (requiring a society to reinstate a member after his expulsion without notice and a hearing, but suggesting that such an expulsion would be allowable in the event of proper notice and a hearing); Cartan v. Father Matthew United Benevolent Soc'y, 3 Daly 20, 20-22 (N.Y. Ct. Comm. Pl. I 869) (holding that a society's refusal to pay disability benefits on the ground that the member was delinquent in paying dues was unreasonable); St. Mary's Beneficial Soc'y v. Burford, $70 \mathrm{~Pa}$. 32 I, 323-25 ( 1872 ) (upholding a denial of benefits because the member's intemperance caused his death); Legal Environments, supra note 6or (author's notes).

$607 \mathrm{See}$ CONNECTICUT REPORT, supra note 582, at 232-35. 
lodge units in turn helped to establish norms of social solidarity among the members. Each lodge adopted the traditional rituals of such venerable fraternal organizations as the Masons and the Odd Fellows. Secret handshakes and gestures, unwritten passwords, and mysterious and arcane initiation ceremonies all found their place in the cooperative insurance societies. ${ }^{608}$

Three additional elements of the structure and operation of the cooperatives functioned to foster mutuality and commitment to the society. First, most cooperatives, especially before the mid-I 890 , operated on an assessment plan. 609 Members were assessed a fixed amount often one dollar - each time the society needed to raise funds in order to pay claims, usually between fifteen and twenty times per year.610 By operating on an assessment basis, the associations argued, they could avoid the expensive and potentially corrupting practice of creating large reserve funds that characterized the old-line commercial companies. ${ }^{611}$ Moreover, the assessment basis served to emphasize the fraternal and reciprocal nature of the beneficiary societies; assessments became not a regular and fixed cost of maintaining one's own insurance account, but rather an irregular obligation linked to fellow members' needs.

Second, members paid equal rates regardless of their age or risk profile. ${ }^{612}$ As one fraternalist recalled, "[t]here was no discrimination on account of age or physical condition or occupation. It was true equality and fraternity." 613 Indeed, like the assessment plan, the use of equal assessment rates rather than risk-adjusted rates emphasized the collective spirit of the cooperative insurance project. To be sure, equal assessment rates effectively required young, low-risk members to subsidize high-risk (often older) members and thus created an adverse selection risk that low-risk members would stay out of the associations altogether. ${ }^{614}$ As we shall see, this adverse selection problem became acute after the turn of the century. But the use of equal rates also cre-

608 See, e.g., BRICKLAYERS' \& PlASTERERS' CONSTITUTION \& BY-LAWS, supra note 552, at 7 (reciting the duties of the door-keeper); CARNES, supra note 485 , at I04-07; THEO. A. ROSS, ODD FEllowSHIP: ITS HISTORY AND MANUAL 575-87 (New York, M.W. Hazen Co. I888); Albert C. STEVENS, THE CYClOPEDIA OF FRATERNITIES (I899) (describing rituals of cooperative and fraternal associations).

609 See William Morse Cole, Co-Operative Insurance and Endowment Schemes, 5 Q.J. ECON. 466, 469-70 (I89I).

610 See Hill, supra note 587 , at 2 (author's notes) (calculating the average annual number of assessments in the Ancient Order of United Workmen between I 875 and I890 as seventeen).

611 Cole, supra note 609, at $47 \mathrm{I}$.

612 See id.

613 INSURANCE RESEARCH AND REVIEW SERVICE, FRATERNAL LIFE INSURANCE 30 (I938) [hereinafter FRATERNAL LIFE INSURANCE].

614 This problem eventually helped to undo the cooperative insurance movement. See infra pp. $822-23$. 
ated a powerful incentive for members to stay in a given society for long periods. The assessments paid by a young member overstated his personal cost of insurance; as an older member, however, that same individual would receive the benefit of having newer members share some of the cost of insuring him against the greater risks that accompanied age.

Third, individuals whose membership lapsed because of failure to meet an assessment were unable to recover any of the investment they had made in the society. ${ }^{615}$ Like the equal rate structure across all age groups, the absence of surrender values created strong incentives for continued membership. By the $\mathrm{I} 880 \mathrm{os}$ some states had enacted regulations requiring that the "old-line" commercial life insurance companies allow a policyholder to recoup some percentage of his investment if he canceled his policy before it became payable. ${ }^{616}$ For the cooperative associations, by contrast, the social compact of the insurance societies emphasized mutuality first and foremost. Assessments were not treated as investments to be recouped by an investor, but rather as contributions to brothers or their families to be reciprocated in case of one's own disability or death.

4. Ethnic, Racial, and Religious Segregation in Cooperative Insurance. - Perhaps because of the importance of norms of mutuality and reciprocity in the cooperative insurance associations, the fraternal ethic generally did not extend across ethnic or religious lines. In virtually all cases it did not extend across racial boundaries. ${ }^{617}$ Over ninety-seven percent of the societies surveyed in the I89 I Connecticut study required that members be white. ${ }^{618}$ Upchurch's United Workmen provided in its constitution that "only white male persons should be eligible to membership" and that "this provision should never be altered, amended, or expunged." 619 Numerous cooperative associations followed the United Workmen's lead and established formal rules of racial exclusion. ${ }^{620}$ The Supreme Secretary of the Empire Knights of Relief of Buffalo, announced one Empire Knight proudly, was "of the pure Anglo-Saxon race." 621 Cooperatives often stooped to the crudest racial characterizations of the day to illustrate a point: The Fraternal

\footnotetext{
615 Cole, supra note 609 , at 476 .

616 STALSON, supra note 469 , at $318-19$.

617 Chronicler of the fraternal movement Walter Basye insisted that "the societies have not been confined by racial, religious, or other bonds." BASYE, supra note 467 , at I 7 . But Basye was nonetheless forced to concede that such ostensible inclusiveness existed only because there were different "organizations for almost all races and creeds." Id.

618 CONNECTICUT REPORT, supra note 582, at I I 9 .

619 STEVENS, supra notc 608, at I 28.

620 See, e.g., id. at I 23, I37, I4 I (discussing the American Legion of Honor, the Home Palladium, and the Independent Order of Mechanics).

621 FRATERNAL MONITOR, Nov. I, I894, at I4 (author's notes).
} 
Monitor, a monthly magazine dedicated to news and opinion relating to fraternal beneficiary associations, published cartoon advertisements for itself contrasting the foolish wastefulness and lack of foresight of three blackface characters with the prudent and upstanding character of the average white fraternalist. 622

Black Americans, excluded from the white cooperative insurance organizations, established their own cooperative insurance associations, such as the Colored Brotherhood and Sisterhood of Honor in Kentucky and the Colored Consolidated Brotherhood of Atlanta. ${ }^{623}$ Although many of the black cooperatives paralleled existing white institutions in structure and even name, ${ }^{624}$ black associations were distinct in a number of ways. Black women took a leading role in mutual insurance associations. ${ }^{625}$ Moreover, among black Americans, the line between cooperative insurance and commercial insurance enterprises was blurred. ${ }^{626}$ Black fraternal organizations such as the Grand United Order of True Reformers in Richmond, the Mutual Aid and Banking Company in New Bern, North Carolina, the Bank of Galilean Fishermen in Hampton, Virginia, and the Sons and Daughters of Peace in Newport News operated insurance programs that were described, in the case of the True Reformers, as the "Gibraltar of Negro Business." 627 In Florida the Afro-American Industrial Benefit Association evolved into the Afro-American Life Insurance Company. ${ }^{628}$ The two largest black life insurance companies - the North Carolina Mutual Life Insurance Company and Atlanta Life Insurance - began as humble affairs, but by the first decade of the twentieth century, they

622 FrATERnAL MONITOR, Dec. I, I 894, at I (author's notes).

623 Stevens, supra note 608, at I3I; see also M.S. STUART, AN ECONOMIC Detour: A HISTORY OF INSURANCE IN THE LIVES OF AMERICAN NEGROES I I-34 (I969) (describing the development of black fraternal organizations). See generally Monroe N. Work, Secret Societies as Factors in the Social and Economical Life of the Negro, in DEMOCRACY IN EARNEST: SOUTHERN SOCIOLOGICAL CONGRESS, I9I6-I9I8, at 342 (James E. McCulloch ed., I969) (I9i8) (same).

624 A black beneficiary organization called the Improved Benevolent and Protective Order of Elks existed until I9I2, when the Benevolent and Protective Order of the Elks, a white association, obtained an order restraining the black association from using the elk as its namesake. ARTHUR PREuSS, A DictionARY OF SECRET AND OTHER SOCIETIES 324-28 (I924). White associations strictly prohibited their members from fraternizing with members of the parallel black organizations. "The Negro Odd Fellows," wrote one Catholic lawyer, "are not recognized by the white lodges of the same name and a member of one of these white lodges who might visit a colored lodge, if indeed he could, would be expelled." Id. at 327.

625 See Elsa Barkley Brown, Womanist Consciousness: Maggie Lena Walker and the Independent Order of Saint Luke, I4 SignS 6ro, 6r6 (I989); Anne Firor Scott, Most Invisible of All: Black Women's Voluntary Associations, 56 J. SOUTHERN HIST. 3 (I990).

626 See STUART, supra note 623, at I9-20.

627 Juliet E.K. WALKer, THE History OF BlaCk Business in AMERiCA: Capitalism, RACE, ENTREPRENEURSHIP I66, I87, 4 I I nn.26-30 (I998).

628 Id. at $\mathrm{I} 88$. 
had emerged as institutions of the first rank in southern black life. ${ }^{629}$ Nor did black self-insurance societies appear exclusively in the South. Even before the great twentieth-century migration of blacks to northern cities, urban blacks in cities like Philadelphia established mutual beneficiary associations to provide for collective self-insurance. ${ }^{630}$

Religious differences also operated as barriers in the formation of fraternal insurance organizations. For example, the Catholic Church barred members from joining non-Catholic secret or fraternal associations. The rule appears to have broken down in later years, ${ }^{631}$ but in the late nineteenth century, the prohibition on non-Catholic associations seems to have had a significant impact. Catholics founded separate insurance associations, including the the Knights of Columbus, established in 1882 in New Haven, and the Catholic Order of Foresters, formed in Chicago in $1883 .{ }^{632}$ The same period witnessed the formation of separate Jewish beneficiary societies in New York and elsewhere. ${ }^{633}$

\section{B. Industrial Accidents, Cooperative Associations, and the Crisis of Free-Labor Citizenship}

Many features of the late nineteenth-century cooperative insurance associations made a good deal of sense in light of the moral hazard and adverse selection problems in disability insurance markets. In this sense, the economic problems endemic to disability insurance markets form a necessary - but not sufficient - part of the explanation of cooperative disability insurance's success. There were, after all, a number of different forms that private insurance might have taken to solve the market problems of disability insurance. ${ }^{634}$ The American cooperative insurance associations, however, adopted an approach to dis-

629 See Glenda Elizabeth Gilmore, Gender and Jim Crow i65-66 (I996); AlexA BENSON HENDERSON, ATLANTA LIFE INSURANCE COMPANY: GUARDIAN OF BLACK ECONOMIC Dignity 3-I9 (I990); WALKER, supra note 627, at I89-90. See generally WALTER B. WeARE, BLACK BUSINESS IN THE NEW SOUTH: A SOCIAL History OF THE NORTH CAROlINA MUTUAL LIFE INSURANCE COMPANY (I973).

$630 \mathrm{See}$ W.E.B. Du Bois, The Philadelphia Negro: A Social Study $22 \mathrm{I}-25$ (Schocken Books 1970) (1899); NiCK SAlvatore, We All Got History: The Memory BoOKS OF AMOS WEBBER 59-67 (I996).

631 In I 924 a publisher circulated a dictionary of non-Catholic fraternal societies as a "reference work" for the "reverend clergy ... on the subject of secret and other societies into which Catholics are liable to be drawn." PREUSS, supra note 624, at iii.

632 Charles W. Ferguson, Fifty Million Brothers: A Panorama of american LODGES AND CLUBS 3OI-303 (I937).

633 See DANIEl SOYER, JEWISH IMmigrant ASSOCIATIONS AND AMERICAN IDENTITY IN NEW YORK, I880-I 939 (I997).

634 The most likely alternative in nineteenth-century America might have involved expressly religious groupings. A host of other forms, such as intensely nationalistic organizations, might also have been adopted. 
ability benefits that centered on the ideals of independence, fraternity, equality, and manliness. Cooperative societies argued that cooperative insurance would allow American workingmen to preserve their independence in an era of wage-earning dependence. Fraternity and equality, they contended, represented virtues under sharp attack in the increasingly hierarchical organization of American economic life. Moreover, cooperative insurance also offered a means for wage-earners to preserve their roles as manly breadwinners for their families, notwithstanding the increasingly acute problems of death and disability from work accidents in industrialized labor.

In short, the cooperative insurance associations of the late nineteenth century sought to preserve the ideals of mid-century free labor ideology in the changing landscape of the postwar decades. For the cooperative insurance societies, the insurance certificate replaced proprietorship as the embodiment of free labor independence. Where once the self-owning wage laborer had been able to rise to the level of master craftsman or independent proprietor with at least a small property holding, now the insurance policy against death and disability allowed the self-owning workingman to invest in the value of his selfownership to protect against the consequences of injury. The worker's body itself would form the new property on which independence could be established by investing in the property value of that body over time through an insurance arrangement. In the equality and fraternity of the cooperative insurance association, the American workingman might thus find a new kind of independence despite the increasingly hierarchical structure of economic life.

Moreover, the cooperative insurance impulse reconceived manliness as the capacity to protect one's family from unforeseen contingencies. "Had it not been for lodge people persuading my husband to join," stated a typical cooperative insurance circular of the day, "myself and the little ones would to-day be in want." 635 Indeed, a typical motto for the cooperatives was "Lupus Repulsus": with the wolf at the door of the widow's modest home, the certificate of the cooperative insurance association promised (in loco patris) to chase the wolf away. ${ }^{636}$

Yet the cooperative associations' attempt to maintain workingmen's economic independence in the face of the accident crisis was, like the free labor ideal itself, a project of deeply ambiguous ideological import. Insurance associations simultaneously embodied a pointed critique of the iniquities of the competitive wage system and an accommodation to that competitive wage system. On one hand, coopera-

635 Contemporary Views, FRATERNAL MONITOR, Sept. I, I89o, at I4 (author's notes).

636 See Advertisement, Order of the International Fraternal Alliance (Boston), FRATERNAL MONITOR, Feb. I, I89I, at I 9 (author's notes). 
tive associations stood as one strand of the late nineteenth-century movement that sought to reconstruct the competitive wage labor system into a "cooperative commonwealth." From this perspective, the industrial accident problem was the starkest exemplar of the crippling effects of wage labor on the nation's workingmen, effects that warranted a thorough reorganization of economic production in the industrial age. On the other hand, for many, cooperative insurance represented a means by which workingmen might adapt to the new industrial order by extending the commodification of their bodies through a private and voluntarist insurance mechanism. ${ }^{637}$ Because the wage labor system rendered the workers' labor power a commodity, the life and disability insurance contract treated the worker's body itself as a marketable commodity. Moreover, from this perspective, life and disability insurance offered a means to manage the contingencies of the new industrial economy, short of a mass reorganization of American economic and social life.

\section{The Ambiguities of Cooperative Insurance}

If cooperative insurance was a response to the threat that industrial accidents posed to workingmen's free labor ideals, it also brought out the ambiguities of these ideals. Within the cooperative insurance movement itself, two competing accounts of cooperation vied for the meaning of the movement. The first account - called here the "thin" theory of cooperation - bore a number of close similarities to the classical liberalism of the law of torts. On this view, cooperation was a process by which rational, self-interested individuals could assume new levels of self-control and responsibility. By contrast, according to a second account - the "thick" theory of cooperation - the cooperative insurance movement was not merely a process for the pursuit of individual interests, but rather an adaptation of the substantive ideal of independence for the free labor workingman to an increasingly industrialized world. ${ }^{638}$

I. The Thin Theory of Cooperation: Cooperative Insurance and the Responsible Self. - No one better captured the thin strand of the post-

637 For discussions of the commodification theme in nineteenth-century life insurance, see Zelizer, supra note 495; and Viviana A. Zelizer, Pricing the Priceless Child: The Changing Social Value of ChILdRen i i 3-37 (I 985 ).

638 I borrow the terms "thin" and "thick" from the political theory literature - derived from Rawls's $A$ Theory of Justice - on the difference between "thin" or minimalist theories of justice, on one hand, which require few substantive commitments to particular notions of the good and take persons as prior to the rich particularities that constitute their ends; and "thick" or full theories of justice, on the other hand, which entail more significant commitments to particular conceptions of the good and take persons as necessarily encumbered by a rich set of social attachments. See JOHN RAWLS, A THEORY OF JUSTICE 396-99 (I97 I); see also JOHN RAWLS, POLITICAL LIBERALISM 178 (1993); SANDEL, LIBERALISM, supra note I53, at 50-65, I 20-2 I. 
Civil War insurance movement than Elizur Wright, Massachusetts's first insurance commissioner. Born in 1804 into a Congregationalist family in Litchfield County, Connecticut, Wright grew up in the heady antebellum world of New England evangelical reform. ${ }^{639}$ Like many antebellum American reformers in the evangelical Protestant tradition, Wright believed deeply in the human capacity for "direct communion to God through conscience."640 As Wright's correspondent and friend Theodore Weld put it, God had "committed to every moral agent the privilege, the right and the responsibility of personal ownership."641 In Wright's view, certain social beliefs followed directly from human beings' capacity for self-responsibility. Thus, for example, he advocated complete abstinence from alcohol and tobacco. Moreover, as a young man in the early r830s, Wright became a leading immediatist in the American abolitionist movement. ${ }^{642}$ Indeed, Wright was named the domestic secretary of William Lloyd Garrison's American Anti-Slavery Society at its inception in $1833 .^{643}$

At the center of Wright's view of the world, and at the heart of his abolitionism, lay his belief in responsibility for one's own moral choices. "God has devolved upon every individual," he wrote, "a certain responsibility towards making civil government what it should be." ${ }^{644}$ Thus, moral suasion and individual action held out the greatest promise for liberty, which could be gained only "by moral power." 645 In focusing on individual action and moral suasion, Wright tapped into the strong current of ideas about human perfectibility in nineteenth-century antislavery thought; if human beings could cast off the burden of original sin, many of the most radical abolitionists argued, then communities might no longer need coercive mechanisms of hierarchy, authority, and governance. ${ }^{646}$ Yet more so than many of his fellow abolitionists, Wright was preoccupied with the persistence of

639 See Philip Green Wright \& Elizabeth Q. Wright, Elizur Wright: The Father of LIFE INSURANCE I (1937). For accounts of the New England antebellum reformers, see generally ROBERT H. ABZUG, COSMOS CRUMBLING: AMERICAN REFORM AND THE RELIGIOUS IMAGINATION (I994); LAWRENCE J. FRIEDMAN, GREGARIOUS SAINTS: SELF AND COMMUNITY IN AMERICAN ABOLITIONISM, I830-I870 (I982); WALKER, supra note 246; and RONALD G. WALTERS, THE ANTISLAVERY APPEAL: AMERICAN ABOLITIONISM AFTER I830 (I976).

640 LaWrence B. GoOdheart, ABolitionist, ACTUARY, ATHEist: ElizUr Wright and THE Reform ImpUlse 44 (I990); $c f$. David Brion Davis, The Problem of Slavery in WESTERN CULTURE 333-64 (I966) (describing Christian ideas about human perfectibility in the eighteenth and early nineteenth centuries).

641 GoODHEART, supra note 640 , at 44 .

642 Id. at 4I; see also R. CARlyle BUley, The AMERICAN Life CONVENTION, I906-I952: A STUDY IN THE HISTORY OF LIFE INSURANCE 57-58 (1953).

643 GOODHEART, supra note 640 , at 64 .

644 Id. at 90 .

645 Id.

646 See David Brion Davis, The Problem of Slavery in the Age of Revolution, i770I823, at 554 (I975); DAVIS, supra note 640, at 298-300. 
tragedy in human life. "Men," Wright wrote to Garrison, "are not completely freed from sin by the grace of God."647 Indeed, Wright was no stranger to tragedy. Five of Wright's children died in the I830s and I840s, and in 1844 his house in Boston burned to the ground, almost taking his wife and remaining children with it. 648

Wright's hesitance to accept the strongest interpretations of human perfectibility led him in I839 to break with Garrison over the latter's increasingly radical platform, which advocated equality for women and the abolition of all forms of human government.649 After his break with Garrison, Wright became increasingly involved in the stillfledgling life insurance industry of the 1840 s and $505 .{ }^{650}$ In 1858 , Wright was named State Insurance Commissioner for Massachusetts, a position he held until $1867 .{ }^{651}$ In these years, as well as in his subsequent career as an independent insurance expert, Wright came increasingly to believe that life insurance offered the best means by which men could continue to assume responsibility for themselves, even in the face of the contingencies of modern life. Life insurance, he argued, solved "the great problem - how to secure independence by means of general dependence." ${ }^{52}$ Indeed, cooperative insurance arrangements of different kinds, according to Wright, would be "a long step taken towards the solution of the great labor questions" of the day. ${ }^{653}$ Thus Wright looked forward to a day when workingmen would adopt life insurance protections "as universally" as the various arrangements of "steam and lightning" that had called workingmen's insurance associations into being in the first place. ${ }^{654}$

In his theory of life insurance, Wright clung to the moral reform ideals of his antebellum abolitionism. Many of his contemporaries in the 1840 os viewed life insurance as little more than a lottery; indeed, before 1800 , life insurance had been seen as little more than a way of betting on lives. ${ }^{655}$ But Wright saw that insurance on lives could serve as a bulwark for the morally responsible self in unsettling times. Insurance against death offered the opportunity to realize "fraternity

647 GOODHEART, supra note 640 , at 103 .

648 Id. at $\mathrm{II}_{7}, \mathrm{I}_{2} 4$.

649 Id. at I03-06.

650 See BULEY, supra note 642, at 58-59; STALSON, supra note 469 , at 232-34; WRIGHT \& WRIGHT, supra note 639, at 220-39.

651 GOODHEART, supra note 640 , at 148 .

652 Id. at I 45 .

653 Id. at 164 .

654 Id. at 163 .

655 For discussion of the eighteenth-century background for the perceived relationship between life insurance and gambling, see generally BULEY, supra note 642, at 13-26; and GEOFFREY Clark, BetTing ON Lives: The Culture OF Life INSURANCE IN ENGLAND, I695-I 775 (I 999). 
without the destruction of independence and individuality." ver, life insurance offered a way to adapt the ideal of moral responsibility for one's own actions to modern conditions without coercively reorganizing the fabric of economic and social life. In essence, Wright viewed life insurance as a uniquely voluntary and individualistic solution to a social problem. Life insurance and other mechanisms of prudence, thrift, and individual responsibility, Wright believed, could make trade unions entirely unnecessary. ${ }^{657}$ Indeed, until his death in I885, Wright argued that if American workingmen would follow the teachings of the antebellum temperance advocates, they would be able to rise above the poverty of urban and industrial life. ${ }^{658}$

Wright was hardly alone in viewing life insurance arrangements as a mechanism for the achievement of personal moral responsibility. The Connecticut Board of Labor Statistics argued that cooperative insurance societies taught citizens the virtues of self-reliance - in the Board's words, "the wisdom of thrift, the independence of self-help, and the pride of self-government."659 Moreover, many cooperative association voices evinced a deeply rooted commitment to insurance as a voluntarist mechanism for accommodating the individual to the dilemmas of industrial life. From this perspective, insurance allowed individuals to solve the social problems that otherwise threatened to result in expansion of the state. The effective use of insurance could thus counter calls for new governmental functions. "We are not of the opinion that insurance forms any of the functions of government any more than the sale of groceries and dry goods," announced The Fraternal Monitor in I891. "Governmental insurance, whether voluntary or compulsory, can never be made a success even under monarchical forms of government." 660 Such opposition to governmental action extended beyond the role of the state in insurance. Many fraternal insurance societies bitterly opposed what they sensed was the "tendency ... towards saddling the government with functions which do not properly belong to it." 661

656 GOODHEART, supra note 640, at i 76 . For Wright's response to the persistent gambling critique of life insurance, see STALSON, supra note 469 , at $15 \mathrm{I}-52$.

657 See GoODHEART, supra note 640, at 165.

658 See id. at 208.

659 See CONNECTICUT REPORT, supra note 582, at 66.

660 Paternalism, FRATERNAL MONITOR, Feb. I, I89 I, at 12 (author's notes).

661 Id. State regulation and supervision of the economy and state assumption of roles such as a seller of insurance, groceries, and dry goods "differ only in degree," wrote the editors of The Fraternal Monitor, "they are both perversions of the true function of government." Id. (author's notes). This antistatist sentiment led many cooperative beneficiary organizations to stay out of politics. The Fraternal Monitor's editors argued as follows:

On general principles it is unwise for the fraternities to enter the domain of politics.... When ... the fraternities essay to occupy this field, their affairs to a certain extent become interwoven with its fortunes, and the advantages to be gained thereby are of a du- 
2. The Thick Theory of Cooperation: Cooperative Insurance and the Cooperative Commonwealth of the Workingman. - If one strand of the insurance movement of the post-Civil War years focused on life insurance's capacity to accommodate the moral responsibility of the individual to a new industrializing era of unforeseen contingencies, a competing approach to cooperative insurance offered very different lessons for the meaning of the accident crisis. On the "thick" account of the cooperative associations, cooperative insurance represented the opening of a new cooperative commonwealth of the independent workingman.

(a) The Cooperative Critique of the Wage System. - Post-Civil War America witnessed a proliferation of cooperative movements seeking to counter the vicissitudes of economic and social change. The key ideal linking all of these movements was the aspiration for what Americans from all walks of life came to think of as a "cooperative commonwealth." In the South and the Midwest, farmers in fraternal orders such as the Rochester-based Patrons of Husbandry (also known as The Grange) and the Texas-based Knights of Reliance founded regional and national Farmers' Alliances dedicated to the cooperative advancement of small farmers' interests in the increasingly troubled agricultural markets of the 1880s. ${ }^{662}$ Farmers' Alliances throughout the agricultural regions of the nation, but especially in the Dakotas and Texas, formed distributive cooperatives designed to cut out the middlemen who controlled farmers' access to markets. ${ }^{663}$ Many Alliances also established cooperative enterprises furnishing such diverse goods and services as coal, barbed wire, farm machinery, and life and fire insurance. ${ }^{664}$ Ultimately, the cooperative farmers' alliances inspired a political movement that had considerable success in the late I 880 s and early I890s running on a "cooperative commonwealth" platform. 665 The Farmers' Alliances and the People's Party, or Populists, which absorbed the Farmers' Alliances in 1896 , advocated the nationalization of railroads, ${ }^{666}$ the creation of state-owned distribution and

bious nature. ... It follows therefore, that no good purposes can be served by political alliances.

Seasonable Paragraphs, FrATERNAL MONITOR, Oct. I, I89I, at 3 (author's notes).

662 See Robert C. MCMATH, JR., AMERICAN POPUlism: A SOCIAL HiSTORY I877-I 898, at 83IO7 (1993) [hereinafter MCMath, AMERICAN POPUlism]; ROBERT C. MCMath, JR., POPUlist VANGUARD: A HISTORY OF THE SOUTHERN FARMERS' ALlIANCE I5 I-52 (I975) [hereinafter McMath, POPUlist VANGUaRd]; C. VANN WoOdward, ORIgins OF THE NEW SOUTH, I877I 1 I 3 , at I 88-90 (2d prtg. I 97 I).

663 Lawrence Goodwyn, Democratic Promise: The Populist Moment in America 39, 59 (I976).

664 MCMATH, AMERICAN POPULISM, supra note 662, at ror.

665 Id. at $83-107$.

666 Id. at I04, I09. 
storage institutions for agricultural goods, ${ }^{667}$ and the extension of below-market-rate loans to producers of agricultural and industrial goods. 668

The farmers were hardly alone in advocating cooperation as the "Key to the Solution of the Industrial Problem of the Age," as Texas Farmers' Alliance leader Charles Macune described it. ${ }^{669}$ In the I880s, middle- and upper-class reformers, as well as many important elements of the labor movement, turned to cooperation as the best alternative to the competitive capitalist organization of American economic and social life. Though they reached very different conclusions regarding the particular reforms necessary to mend the rent fabric of the nation, popular social reformers such as Edward Bellamy, Henry George, and Henry Demarest Lloyd saw some form of cooperation as critical to their projects of social reform. Bellamy's I887 novel Looking Backward envisioned a federally supervised reorganization of the economy on the model of a cooperative family and inspired a movement of $\mathrm{Na}$ tionalist Clubs advocating like-minded reforms. ${ }^{670}$ Unlike Bellamy, George advocated an approach to industrial difficulties that avoided a strong national state. Thus, George's 1879 Progress and Poverty argued in favor of heavily taxing ground rents and redistributing the revenue. ${ }^{671}$ But like Bellamy's nationalist utopia, George's tax plan was inspired by and sought to inculcate a new spirit of self-regulation by a "community of honest producers free from artificial restraints and special privileges" - a community in which cooperatively determined bounds would place sharp limits on the proper scope of the marketplace. ${ }^{672}$ Similarly, Lloyd's 1894 Wealth Against Commonwealth, an indictment of the Standard Oil Company, advanced cooperation among small independent producers as an alternative to monopoly production. ${ }^{673}$ Lloyd even became a director of the American Co-

\footnotetext{
667 GoodwyN, supra note 663 , at 90-93, 109-1 3 .

668 Id. at I09-10.

669 MCMATH, POPULIST VANGUARD, supra note 662 , at 90 .

670 EDWARD BELlAMY, LOOKING BACKWARD, 2000-I887 (Belknap Press I967) (I888). For more on Bellamy, see ARTHUR LIPOW, AUTHORITARIAN SOCIALISM IN AMERICA: EDWARD Bellamy \& The Nationalist Movement (I982); and John L. Thomas, Alternative America: Henry George, EdWARd Bellamy, Henry Demarest lloyd and the ADVERSARY TRADITION ( 1983 ).

671 See HenRy GeORge, Progress ANd Poverty 408-2 I (Robert Schalkenbach Found. 1929) (I879); THOMAS, supra note 670, at I I 8-22.

672 THOMAS, supra note 670 , at ro8. George thought of his self-regulated community as preserving the competitive functions of the market, see GEORGE, supra note 67I, at 316-19, but such competition only took place in George's schema within a general framework of cooperatively agreed-upon bounds. See generally ChARLES Albro BARKer, HeNRY GeORge 294 (I955); STEVEN B. CORD, HENRY GEORGE: DREAMER OR REALIST? 228-34 (I965); ANNA GEORGE DE MILLE, HENRY GEORGE: CITIZEN OF THE WORLD (Don C. Shoemaker ed., I 950).

673 See Henry Demarest Lloyd, Wealth Against Commonwealth i 7 I-84 (Thomas C. Cochran ed., Prentice-Hall, Inc. I963) (1894); see also ChEster MCARTHur Destler, HenRY
} 
operative Union, a leading American cooperative organization, and published a book for an American audience on experiments in "labor copartnership" in England and Ireland. ${ }^{674}$

Both the Farmers' Alliances and reform writers in the cooperative tradition forged connections in the late 1880 s to the labor movement, which had developed its own variation on the postwar cooperative ideal. The Farmers' Alliances in particular established farmer-worker coalitions with the Knights of Labor. ${ }^{675}$ Similarly, George and Lloyd established relationships with industrial workingmen in the Knights. ${ }^{676}$

Much as the Farmers' Alliances grew out of local agricultural fraternities, the Noble and Holy Order of the Knights of Labor developed in the I86os out of a mysterious and little-understood set of local tradesmen's secret societies in Philadelphia.677 With the addition of miners in the I870s, and then skilled tradesmen in the early I880s, the Knights became the United States's leading labor organization by the early to mid-I880s. ${ }^{678}$ Moreover, the Knights brought together under one tent a wide array of trades, and in a few instances they successfully crossed the ethnic and racial boundaries that divided American labor. ${ }^{679}$

Cooperation and the cooperative commonwealth ideal lay at the core of the Knights' mission. The preamble to their constitution announced that the Knights endeavored "to establish co-operative institutions, such as will tend to supersede the wage system by the introduction of a co-operative industrial system." 680 According to Terence Powderly, the Grand Master Workman of the Knights, the nation's workingmen would only be free of the bonds of wage slavery when the "rotten" competitive system "g[a]ve way to the true co-operative system." 681 As he typically proclaimed at the Knights' conventions, cooperation would make it possible to recapture the Lincolnian dream of "every man his own master - every man his own employer." 682

The Knights were only the most striking manifestation of a still broader movement among the "producing classes" of workingmen

DEMAREST LLOYD AND THE EMPIRE OF REFORM 296-300 (I963); THOMAS, supra note 670, at 30I-04.

674 See DESTLER, supra note 673 , at $380,389$.

675 See MCMATH, AMERICAN POPULISM, supra note 662, at 83-107.

676 See id. at I I3; THOMAS, supra note 670, at 280.

677 See LEON FINK, WORKINGMEN'S DEMOCRACY: THE KNIGHTS OF LABOR AND AMERICAN POlitics, at xii (I983); ROBERT E. WeIR, BEYOND LABOR'S VeIl: THE Culture OF THE KNIGHTS OF LABOR 2 (I996).

678 See FINK, supra note 677 , at xii.

679 See POWDERLY, supra note 572, at 347-5 I; see also FINK, supra note 677, at I49-77, 224.

680 POWDERLY, supra note 572 , at 230.

681 Id. at 233 .

682 Terence V. Powderly, The Path I Trod: The Autobiography of Terence V. POWDERlY 269 (Harry J. Carman, Henry David \& Paul N. Guthrie eds., I 940). 
against market trends that were undermining prevailing modes of production and social organization. Among industrial workers, this producerist worldview's central tenet was the labor theory of value. ${ }^{683}$ Drawing on both Locke and Marx, American workingmen in the I880s argued that wealth was the product of the noble labor of the working classes. ${ }^{684}$ Accordingly, the profits of production rightfully belonged to the producers. Yet the wage system of labor withheld from the worker his equitable share of the returns from production. In the process, the wage system stripped the workingman of his dignity in labor and reduced him to a state of wage slavery.

Cooperation, by contrast, offered a model of production that might preserve the dignity of the workingman and restore to him a fair return on his productive capacities. Thus, in the decades between the Civil War and the turn of the century, the main theme of the American labor movement centered on the cooperative alternative to wage labor. An outpouring of radical labor pamphlets decried the "degrading" and "monarchial"685 social economy by which capitalist wage labor "rob[bed]" 686 the producing classes of what was rightly theirs. In contrast, the promise of what labor radicals variously called an "American co-operative labor social economy," 687 an "[e]conomy of [c]ooperation,"688 or "universal co-operation" 689 was that it might ensure the workingman an equitable share of the wealth he created. ${ }^{690}$

(b) Cooperative Insurance and the Critique of the Accident Crisis. - For the cooperationists, the law of employers' liability for industrial accidents was a leading example of the inequitable distribution of the profits of enterprise. If labor was the source of value in the production process, the competitive capitalist economy stripped the workingman of his rightful share of the returns on production yet left him to bear

683 See DaNiel T. Rodgers, THE Work ETHIC IN INDUSTRIAL AMERICA I850-I920, at 2 I3I4 (1978). Rodgers emphasizes that common references to labor as the source of wealth were not necessarily doctrinaire Marxist claims about labor time and the production of surplus value. $I d$. at 2 I 7-I8. This proposition is surely correct, but the significance of the distinction may be relatively small. As David Montgomery has shown, for example, the American labor theory of value led labor radicals to a number of conclusions not altogether different from those that they might have drawn from Marx's Das Kapital. See MONTGOMERY, supra note I5 I, at 25 I-57.

684 RODGERS, supra note 683 , at 2 I3-14.

685 WALTER S. WALdie, AMERICAN CO-Operative Labor SOCIAL ECONOMY Vs. MONARCHIAl LABOR DEgRAdiNg SOCIAL ECONOMY 24 (Philadelphia, Sherman \& Co. I87I).

686 J.M. BloOMER, THE COOPERATIVe EduCATOR: A Key to the Mines OF Wealth ACCessible to Honest Producers Who Think AND ACt For Themselves 2 (Toledo, News

Publ'g Co. 1888).

687 WALDIE, supra note 685 .

688 BLOOMER, supra note 686, at 9.

689 William Haller, The New Idea: Universal Co-operation and Theories of FutURE GOVERNMENT 8 (Cincinnati, H. Watkin, Printer n.d.).

690 Franklin Henry Giddings, Twelve Principles of CoOperation (New York, Sociologic Society of America I887). 
the increasingly grave risks of personal injury and death. These circumstances stood squarely at odds with the moral economy of the cooperatives. Terence Powderly of the Knights of Labor became a labor radical as a child growing up near the anthracite mines of Pennsylvania, listening to miners' unions condemn the mine operators for their callous disregard of miner safety. ${ }^{691}$ Building trades union leader Edward H. Rogers argued that "justice and equity" required employers' liability reform. ${ }^{692}$ Similarly, fellow labor leader George E. McNeill explained that it was a "scandal" that "a man is pensioned for wounds" received in warfare, "but must be pauperized when receiving injuries in the peaceful pursuits of life."693 In industrial workplaces, McNeill observed, "[t]he slaughter continues" without the fanfare given to lives destroyed on the battlefield. ${ }^{694}$

Organized protest against the law of employers' liability appears to have been rare among American workingmen into the late $1860{ }^{695}$ In 1868 , the National Labor Union added Rogers's call for liability reform to its political platform. ${ }^{696}$ By the $\mathrm{r} 880 \mathrm{0}$, employers' liability law reform appeared regularly as a legislative goal of workers' organizations, alongside maximum hours laws, land reform, and repeal of the law of labor conspiracies. ${ }^{697}$ Similar liability reforms became important in the legislative agenda of the railway brotherhoods.698 Even then, however, labor unions in the late nineteenth century rarely made workplace safety or employer compensation of injured workers central issues in collective bargaining with employers. ${ }^{699}$

Protest against the political economy of the law of employers' liability emerged not so much in organized political lobbying for liability rule reform or in collective bargaining over safety conditions as in the overlap between the cooperative insurance societies and the coopera-

691 See POWDERLY, supra note 682, at 23-24.

692 The Labor Movement: The Problem of To-DaY $33^{2}$ (George E. McNeill ed., Boston,

A.M. Bridgman \& Co. 1887 ).

693 Id. at 490.

694 MCNEILL, supra note 286 , at 65.

695 John Fabian Witt, Note, The Transformation of Work and the Law of Workplace Accidents, I842-1910, IO7 YALE L.J. I467, I481-82, I482 n.79 (1998). In New York in the I850s, labor activists advocated land reform, mechanics' lien laws, minimum wage legislation for public works, maximum hours legislation, and repeal of the law of labor conspiracy, but not employers' liability reform. See The Congress of Trades, N.Y. HERALD, July 26, I850, at I; The New-York City Industrial Congress, N.Y. DAILY TRIB., Sept. $25, \mathrm{I} 850$, at 8.

696 See 9 A DOCUMENTARY HISTORY OF AMERICAN INDUSTRIAL SOCIETY 224 (John R. Commons \& John B. Andrews eds., I9IO).

697 See Robert Asher, Failure and Fulfillment: Agitation for Employers' Liability Legislation and the Origins of Workmen's Compensation in New York State, I876-I9Io, 24 LABOR HIST. I98, 20203 (I983); Witt, supra note 695, at 1482 n.79.

698 See SALVATORE, supra note $\mathrm{I}_{3}$, at $42-43$.

699 See William Graebner, Coal-Mining Safety in the Progressive Period: The POLITICAL ECONOMY OF REFORM I 28 (I976). 
tive commonwealth movement more generally. The Brotherhood of Locomotive Firemen, later led by Eugene Debs, formed in the early I870 not as a labor union, but as a fraternal mutual insurance society first and foremost. ${ }^{700}$ By the same token, many of the early producers' cooperatives featured collective insurance programs, ${ }^{701}$ and some were primarily organized as such..$^{702}$

Indeed, for many supporters of a cooperative political economy, cooperative insurance associations were just one part of the broader cooperative movement. ${ }^{703}$ Some cooperationists believed that the cooperative insurance societies, with their relatively simple assessmentbased administration, would serve as an entry wedge for the cooperative movement more generally; in the fraternal insurance associations, cooperative members would learn the habits of cooperation and its benefits. ${ }^{704}$ For other cooperationists, cooperative insurance societies represented a way-station that would provide benefits to the "casualties" of industrial capitalism during the interval before the cooperative economy established itself. ${ }^{705}$

The problem of upholding the independence of the workingman in the face of the onslaught of industrial injuries even led some free labor radicals and advocates of the cooperative commonwealth vision to turn to full-time work in mutual accident insurance. George E. McNeill led the American eight-hour movement from the I860s into the I88os, first as secretary of the Grand Eight-Hour League and then as president of the Workingmen's Institute and the Boston Eight-Hour League. ${ }^{706}$ In 1883 he joined the Knights of Labor, and throughout the 1890 os he maintained close ties to the AFL. ${ }^{707}$ Into the first decade

700 SALVATORE, supra note 183 , at 20.

701 See, e.g., ARticles of Association of THE WinNebago CoUnty INDUSTRIAL AND Provident Society 2 (Oshkosh, Wis., Levy \& Ryckman, Printers I878); Constitution OF THE WORKINGMEN's LEAGUE I (n.p., n.d.) [hereinafter WORKINGMEN'S LEAGUE CONSTITUTION]; CONSTITUTION OF THE WORKMEN'S SICK \& DEATH BENEFIT FUND OF THE UNITED STATES OF AMERICA I5 (New York, John Oehler, Printer I899) [hereinafter WORKMEN'S SICK \& DEATH Benefit Fund Constitution]; The Industrial Republic, Founded on Fraternal CoOPERATION (n.p., I89I).

702 See Workingmen's League Constitution, supra note 70I; WORKMEN's Sick \& DeATH BENEFIT FUND CONSTITUTION, supra note 70I, at 8.

703 See NELSON BOOTH, EXPERIENCES AS CO-OPERATORS 6 (n.p., n.d.).

704 See PROSPECTUS OF THE AMERICAN WORKERS' ALliaNCE FOR THE ADVANCEMENT OF EDUCATIONAL, INDUSTRIAL, COOPERATIVE, AND SOCIAL REFORM 6 (I879).

705 See William Nelson Black, Ultimate Finance: A True TheORy of Co-Operation 42 app. (New York, Humboldt Publ'g Co. ז888).

706 See MONTGOMERY, supra note I5 I, app. D at 467; I5 AMERICAN NATIONAL BIOGRAPHY I 70, I 70-7 I (John A. Garraty \& Mark C. Carnes eds., I999); I 2 DICTIONARY OF AMERICAN BIOGRAPHY I50, I 50-5 I (Dumas Malone ed., I933).

707 is See AMERICAN NATIONAL BIOGRAPHY, supra note 706, at I 7 I. 
of the new century, McNeill remained an important participant at cooperative movement conventions. ${ }^{708}$

In McNeill's view, the wage labor system usurped the independence of the free laborer and transformed him into "a man without the rights of manhood." 709 Moreover, McNeill believed that the accident problem among wage laborers was the most glaring instance of the ill effects of wage labor. Accidents reduced the workingman to a "physically ... deformed" creature, "ek[ing] out ... [a] mere pittance" "at the risk of health and limb, and perhaps life." 10 McNeill argued that ultimately only the consolidation of a "Grand Army of Labor" could "lift the laborer to a higher level of manhood." 11 In the meantime the problem of work accidents required the creation of collective worker institutions that could help maintain the independence of workingmen and their families during times of disability. Thus, in I $883 \mathrm{McNeill} \mathrm{es-}$ tablished the Massachusetts Mutual Accident Association. The Association's primary function, as the high proportion of work accidents among the accidents listed in its records reveals, was to provide insurance for men injured at work. ${ }^{712}$

The collectivist structure of the cooperative self-insurance societies often gave voice to the broad social philosophy and the labor theory of value of the cooperative commonwealth ideal. Cooperative insurance societies, the movement's leaders contended in I89I, involved nothing short of "the warp and woof of American citizenship." 13 Three years later Nathan S. Boynton, the president of the National Fraternal Conference, envisioned a cooperative reconstruction of the American economy as a producers' commonwealth. "If the national fraternal beneficiary societies can successfully combine," Boynton asked, "why cannot the labor organizations of the country absorb, manage, and direct the wealth they produce and keep it out of the pockets of the nonproducers, the Goulds and Vanderbilts?" Indeed, through "cooperation," Boynton contended, America's producing classes would soon be able

to own, control, and manage the railroads, the mines, the printing offices, and all of our manufacturing enterprises, without any strike, contention or paralysis of business just as the great fraternal beneficiary system has se-

708 See Handbill, National Co-Operative Conference at Lewiston, Maine, June 2024, I 902 (listing George McNeill, “'the grand old man'” of the labor movement, as the lead speaker).

709 THE LABOR MOVEMENT, supra note 75, at 455. McNeill argued, inter alia, that the wage laborer's "wife is forced from home, and his children from school." Id.

710 Id. at 466.

711 Id. at 468,463 .

712 See MCNEILL, supra note 286 , at 47 . More than four of every ten accidents reported to the association by its members were work-related, as compared to only I.5 of every ten for the next largest category, accidents "about house and grounds." See id.

713 Fraternal MONITOR, Aug. I, I89I, at 5 (author's notes). 
cured control of a vast business, representing four billions of dollars, and are successfully controlling and managing it without any conflict with capital, and without a single strike, boycott, or lockout.

In no other way, in my opinion, will the contention between labor and capital ever be settled .... It is only a matter of time in my opinion when it will be successfully carried out. ${ }^{714}$

Boynton, then, saw in workingmen's cooperative fraternal insurance the promise of cooperation writ large.

Boynton was hardly alone in this view. Abb Landis, a cooperative insurance advocate from Nashville, argued that the success of the cooperative insurance movement was a harbinger of the cooperative economy to come. "No thoughtful observer can regard our present industrial régime as final," wrote Landis just after the turn of the century. ${ }^{715}$ According to Landis, the "remittent warfare between capital and labor" showed that the existing economic system was "obviously a temporary condition." 716 Cooperative insurance societies, however, demonstrated that the "capitalist and labor may be combined in the same person, and that great industries may be competently managed by officers elected by the whole body of the workers." 11 "Why is it not possible," Landis asked, "to extend this principle of mutual cooperation and entirely eliminate the capitalist and forever be rid of his exploitation of labor with its attendants of friction and ferment?"718 In the place of trusts, bankers, and dividends to stockholders, Landis, like Boynton, envisioned an economic structure that rewarded labor in proportion to its equitable share of inputs in the productive process.

3. The Ambivalences of Cooperative Insurance. - Boynton's and Landis's shared vision of cooperation as a model for social life, however, was but one strand of the deeply ambiguous cooperative impulse in the late nineteenth century. Their view of the cooperative movement, and of cooperative workingmen's insurance in particular, promised a thoroughgoing reconstruction of American political economy. But the "thin" variation of cooperative insurance easily accommodated itself to competitive capitalist markets. On Wright's account, after all, cooperative insurance did not have sweeping implications for the shape of the economy. It promised instead to reconstruct the individual by fostering personal moral responsibility.

The difficulty for advocates of the transformative conception of the insurance associations was that the concept of cooperation was inde-

714 FRATERNAL MONITOR, Dec. I. I 894, at 7 (author's notes).

715 Abb Landis, Life Insurance by Fraternal Orders, 24 ANNALS AM. ACAD. POL. \& Soc. SCI. 475,487 (I904).

716 Id.

717 Id.

718 Id. at $487-88$. 
terminate. The corporation is easily redescribed as a profit-seeking capital cooperative. ${ }^{719}$ And in the hands of liberal advocates of laissez-faire such as E.L. Godkin, editor of The Nation, cooperation represented little more than a convenient mechanism by which workingmen could participate in the production of goods and services in an industrial economy. ${ }^{720}$ As geologist and Mormon theologian Dr. James Edward Talmage observed, cooperation could be reconceived as nothing more than the means by which "laborers became their own capitalists."721

Black and immigrant insurance associations shared the same deeply divided identity. W.E.B. Du Bois and Booker T. Washington both advocated cooperative insurance among blacks as a form of collective self-help in the context of racially discriminatory insurance and financial institutions. ${ }^{722}$ But the implications of their cooperative visions differed sharply. For Du Bois, cooperative insurance, like cooperative economic action more generally, constituted a step toward the cooperative reorganization of economic life. ${ }^{723}$ For Washington, however, black self-help institutions such as mutual insurance enterprises might be a way for black Americans to develop commercial acumen. ${ }^{724}$ Similarly, ethnic insurance societies among the new immigrants of the early twentieth century found themselves torn between a desire to foster tight bonds within their communities and an impulse to provide institutional support for the Americanization of immigrants and their introduction into the American commercial economy. ${ }^{725}$

In part, the conflicting ideologies in cooperative workingmen's insurance resulted from the need to adapt the cooperatives' ideological commitments to the realities of running a going concern. As one cooperative organ observed, cooperatives needed always to attend to the

719 For a review of the "capital cooperatives" analogy in the I990s, minus the "scheming capitalists" of the I89os version, see HANSMANN, supra note 492, at I2-14. See also WM. H. TEMPLETON, OFFICE OF THE EXECUTIVE COUNCIL, UNIVERSAL CO-OPERATIVE ASSOCIATION 2 (contending that the "scheeming [sic] capitalists" had "formed co-operative associations, not that justice might be done to the laboring man equally with themselves, but . . . that they might by their great strength of co-operation crush the power of the organizations of the laboring people").

720 See E.L. Godkin, Cooperation and Character, 43 NATION 305 (I886); see also RoDGERS, supra note 74 , at $44-47$. This is essentially the approach of Hansmann today, whose book studies a variety of enterprises and uses microeconomic theory to make sense of the use and success of different ownership structures in different sectors of the economy. See generally HANSMANN, supra note 492 .

721 What It Is Not. What It Is., INDUS. REPUBLIC, Sept. 24, I89 I.

722 See WALKER, supra note 627, at I87-93.

723 DU BoIs, supra note 630, at $22 \mathrm{I}-25,233-34$ (discussing economic self-help in the black communities of Philadelphia); W.E.B. Du Bois, Resolutions of the Conference, in ECONOMIC COOPERATION AMONG NEgRo AmERICANS 4 (W.E.B. Du Bois ed., I907).

724 See WALKER, supra note 627, at I87-93.

725 See, e.g., Lizabeth Cohen, Making a New Deal: INdustrial Workers in ChicaGo, I9I9-I 939, at 53-97 (I990); SOYER, supra note 633, at 3-9. 
"two sides" of cooperation, "the business side, and ... the social and educational side." ${ }^{26}$ Yet the ideological and business sides of the cooperatives were in some ways tightly interwoven because a cooperative society's survival depended upon the inculcation of loyalty to the society. Fostering group loyalty was prerequisite to a cooperative society's ability to combat the endemic difficulties of moral hazard and adverse selection. Without such loyalty and group commitment, cooperatives could unravel quickly, even when only a relatively small proportion of the membership lacked the requisite commitment to the enterprise. ${ }^{727}$ Such a propensity to unravel did not bode well for a movement split by a deep ideological divide.

\section{The Unraveling of Cooperative Fraternal Insurance}

I. The Shortcomings of Cooperative Insurance Societies: HighRisk Exclusions. - There is much to be said for the effectiveness and wide impact of the fraternal and cooperative insurance associations. Indeed, a growing literature has picked up this strand of the story to advance a dubious argument for the viability of private alternatives to the welfare state. ${ }^{728}$ But cooperative self-insurance also had a number of shortcomings, not the least of which were the exclusion of high-risk applicants from the insurance pool and the inadequacy of benefit levels in many smaller cooperative associations.

From the beginning, cooperatives instituted a rigorous process of medical screening for prospective members. R.N. Seaver, chair of the National Fraternal Congress's committee on Medical Examiners and

\footnotetext{
726 The Co-Operative Association of America, CO-OPERATOR, Nov. I89 I, at 4.
}

727 As Thomas Schelling has described in other contexts, the macroeffects of micromotives can be devastating for social movements. See generally THOMAS C. SCHELling, MiCROMOTIVES AND MACROBEHAVIOR (I978).

728 See supra pp. 78I-82. David Beito's recent book is a wonderful example of the disconnect between the historical record and the policy prescriptions in recent literature favoring resurrection of private cooperation. In the last few paragraphs of his book, Beito bemoans the fact that fraternal association membership "no longer includes the very poor" because state welfare programs have crowded out voluntary mutual assistance. Summoning an imaginary golden age of Victorian responsibility and self-help, he concludes that " $[\mathrm{t}] \mathrm{he}$ old relationships of voluntary reciprocity and autonomy have slowly given way to paternalistic dependency." BEITO, supra note 47 I, at 234 . Now there is much to be said for the claim that state entitlements and cooperative mutual assistance embody and foster two very different conceptions of politics. As I hope should be clear to the reader, it is not at all clear that cooperative associations uncomplicatedly represented the principle of autonomy rather than, say, mutualistic solidarity and collectivism. More troubling, however, is the implication that once upon a time the "very poor" belonged to mutual aid associations that offered substantial assistance to their members. Beito spends the better part of a chapter explaining that cooperative mutual assistance associations survived precisely by excluding the least fortunate members of the community from membership. The sick, the injured, the very poorest - all of these groups were excluded from most cooperative insurance associations, which were quite reasonably concerned with the heavy burdens that such individuals would place on association resources. See BEITO, supra note 47 I, at 44-62. 
Examinations, announced in grandiosely mixed metaphor that medical examinations were "the very foundation stones of the whole fabric of Fraternal Protection." 729 When Seaver turned to the question of how to admit new members, he abandoned the rhetoric of fraternity for the language of the business of insurance: "[I]n so far as the Medical Examinations are concerned ... it is a purely business enterprise in which we are each and every one mutually interested, and whatever affects the interests of one affects the interests of all others ..." 730 As another committee member put it, it was necessary that each fraternity's medical examiner be a physician "having the courage to fearlessly do his duty" and "guard[] our gates."731

In "guarding the gates," however, cooperative insurance societies excluded many of the most vulnerable segments of the community. Physicians conducting medical screenings asked prospective members about their families' medical histories, as well as their own; a parent's death from consumption might be enough to exclude a would-be member. ${ }^{732}$ The standard medical examination form of the Royal Arcanum required prospective applicants to list all physicians with knowledge of their physical condition and required the applicants to waive any doctor-patient privilege that might attach to medical information about the applicant or render a physician incompetent to testify against the applicant in court. ${ }^{73}$ Although such medical screenings made good actuarial and business sense, in practice they limited to the healthiest members of the community the scope of the associations' benevolence and fraternity.

2. Low-Risk Flight, Lapses, and Ponzi Schemes. - The exclusion of high-risk members from cooperative self-insurance societies highlighted the cooperatives' need to maintain a steady influx of young, low-risk members. Most commercial life insurance mechanisms in the late nineteenth century employed a system of building reserves while policyholders were young, charging higher premiums as policyholders aged, or reducing benefit levels for aging policyholders. ${ }^{734}$ But in the name of fraternal ties among members, the American cooperative societies adopted an assessment system of equal rates and equal benefits for members of all ages. ${ }^{735}$ As a result, young (typically, low-risk)

729 Document $F$, Nat'L Fraternal Cong., Journal OF Proceedings, Nov. 2 I, I888, at I5I6 [hereinafter NFC JOURNAL OF PROCEEDINGS].

730 Id. at $\mathrm{I} 6$.

731 Id. at 45 .

732 See, e.g., Davis v. Supreme Lodge Knights of Honor, 54 N.Y.S. 1023, I024 (App. Div. I898) (upholding a claim for benefits where an association alleged that the decedent had misrepresented his family's history of consumption).

733 See, e.g., Foley v. Royal Arcanum, 45 N.E. 456, 457 (N.Y. I896).

734 See Cole, supra note 609, at 470.

735 See supra p. 803. 
members effectively subsidized the insurance of older (typically, highrisk) members. Such a system could work, as insurance experts at the turn of century observed, but it required that each society have a stream of new young members able to pay for the insurance of aging members. ${ }^{736}$ In the caustic words of one insurance expert, for the cooperative insurers to succeed without robbing the final generation of new members of their assessment payments, they would need to "continu[e] business to the end of the world, always increasing in numbers." 737

Cooperative insurance societies continually worried about adding young and healthy members to their memberships, as well as screening out poor insurance risks. But they also had to worry about the flight of low-risk members once they joined. ${ }^{738}$ A younger member could significantly reduce the cost of his insurance by leaving a society burdened with a relatively large number of older, high-risk members. Indeed, when the cooperative associations began to mature in the late I 870 s and early I 880 s, the number of new cooperative insurance associations grew sharply as low-risk members of existing societies splintered off into new, lower-cost associations. ${ }^{739}$ One student of insurance associations estimated that by $\mathrm{I} 888$ there were as many as $\mathrm{I} 200$ American insurance societies. ${ }^{740}$ The creation of new cooperatives accelerated in the r89os. As one study found, of 568 societies whose founding dates could be ascertained, only 78 were founded before I880; far and away the largest cohort - some 230 societies - were founded in the five years after $1895 \cdot{ }^{741}$

As new societies sprang up, older societies died off in high numbers. Between $\mathrm{I} 88 \mathrm{I}$ and $\mathrm{I} 885$, seventy-three cooperative insurance associations failed in New York state alone. ${ }^{742}$ A year later, nineteen additional cooperative insurance societies had gone out of business. ${ }^{743}$ With each succeeding year a new host of failures arrived: seventeen in

\footnotetext{
736 See, e.g., HENDERSON, supra note 535 , at I 17.

737 Cole, supra note 609 , at 474 . In this respect, the cooperative associations anticipated the structure of the federal old-age pension system under the Social Security Act.

738 See Fraternal MONITOR, Nov. I, I894, at 9 (author's notes) (describing the problem of exit by younger or healthier members).

739 See, e.g., CONNECTICUT REPORT, supra note 582.

740 See William C. Niblack, The LaW of Voluntary Societies and Mutual Benefit INSURANCE \& I62, at I9I (Chicago, Callaghan \& Co. I888).

741 Meyer, supra note $47 \mathrm{I}$, at $655-56$.

74226 ANN. REP. SUPERINTENDENT OF THE INS. DeP'T of the STATE OF N.Y., pt. II, at xi (Albany, Weed, Parsons \& Co. I885).

74.327 ANN. REP. SUPERINTENDENT OF THE INS. DEP'T OF THE STATE OF N.Y., pt. II, at xviiixix (Albany, Argus Co. I886).
} 
$\mathrm{I} 887 ;^{744}$ ten in $\mathrm{I} 888 ;^{745}$ sixteen in $\mathrm{I} 889 .{ }^{746}$ By $\mathrm{I} 905$ several hundred associations either had ceased reporting to the state superintendent of insurance or had been officially placed in receivership. ${ }^{747}$

Criticism of the fraternals' financial structure mounted in the I89os as low-risk members continued to flee and new associations arose to lure away such members from older societies. ${ }^{748}$ The cooperatives responded to such criticism by pointing to lapse rates as the means by which societies could remain solvent while maintaining equal assessment rates and equal benefits for members without regard to age or risk profile. When members left a cooperative insurance association (or "lapsed"), they forfeited the value of their paid-in assessments. The resulting surplus, argued the fraternalists, allowed the cooperative insurance associations to maintain their fiscal solvency over time. ${ }^{749}$

The lapse argument, however, was startlingly unfraternal in its implications. Existing members essentially funded their own benefits by expropriating the paid-in assessments of lapsed and often less fortunate members. Moreover, the lapse imperative opened the floodgates in the 1880 os and 1890 os for a series of Ponzi-scheme operations in the guise of fraternal insurance associations. ${ }^{750}$ These newly-dubbed "endowment societies" observed that, because of high lapse rates and the consequent forfeiture of benefits by other members, death benefit insurance associations paid out to certain members significantly more than those members had paid in. For members who stayed in and reaped the benefits of lapsed members' contributions, such associations offered an extraordinary investment opportunity. The difficulty with

74429 ANN. REP. SUPERINTENDENT OF THE INS. DEP'T OF THE STATE OF N.Y., pts. II, III, at xxviii (n.p., Troy Press I888).

745 3 I ANN. REP. SUPERINTENDENT OF THE INS. DEP'T OF THE STATE OF N.Y., pts. II, III, at $\mathrm{xxv}$ (Albany, James B. Lyon I890).

746 Id.

74746 ANN. REP. SUPERINTENDENT OF THE INS. DEP'T OF THE STATE OF N.Y., pts. III, IV, at xxii-xxvi (Albany, J.B. Lyon I 905).

748 See, e.g., SHEPPARD HoMANS, Limitations of ASSESSMENT InSURANCE (New York, The Spectator Co. I $8 \rightarrow$ Francis B. Forbes, Notes on Fraternal Beneficiary Corporations Doing Business in Massachusetts, 8 PUBLICATIONS AM. STAT. Ass'N I, 2-3 (I902) (calling for greater state oversight of the cooperative insurance societies). Some of the criticism of fraternals came from commercial insurance companies, which rightly perceived fraternals as competitors in the life insurance market. As Henry Hyde, founder and president of the Equitable Life Assurance Society (one of the "Big Three" commercial companies), wrote to a vice president in 1887 , "we must make a sharp attack upon co-operatives, as we are being troubled by them a good deal." KELLER, supra note 493, at 7 I (internal quotation marks omitted). In league with other commercial life insurance companies, Hyde's firm implemented a propaganda campaign against the cooperatives. Id.

749 See, e.g., Editorial, FRATERNAL MONITOR, Sept. I, I890, at 8 (author's notes) (arguing that lapse rates support the financial viability of cooperative insurance societies); see also Annual Report of the Committee on Statistics and Good of the Orders, Fraternal. MONITOR, Aug. I, Igi I, at I6-I 8 (author's notes) (reporting on lapse rates).

750 See Frank P. Bennett, The "Endowment" Craze in Massachusetts, I892 AM. J. POL. 5I4; Cole, supra note 609 , at 487-9.3. 
the standard death benefit of the life and disability insurance associations, however, was that "you ha[d] to die to win." 751 What, reasoned the endowment associations, prevented an association from moving up the payment date? In fact, what prevented an association from accelerating the assessment schedule and accomplishing for live members in five years a result that took the death benefit societies thirty years to accomplish for dead members?752

In the late I 880 s and early I890s, endowment association lobbyists induced state legislatures to legalize endowment insurance contracts. ${ }^{753}$ At the outset, endowment benefit organizations such as The Iron Hall promised $\$ 1000$ certificates maturing in seven years, at a rate of $\$ 2.50$ per assessment. ${ }^{754}$ Not to be outdone, the Sexennial League promised $\$ 1000$ after six years; ${ }^{755}$ the Anti-Poverty Association of the Age advertised its ability to reduce the period before maturity on the same $\$ 1000$ to five years while guaranteeing sickness, accident, and funeral benefits in the meantime. ${ }^{756}$

Many of these associations were wholly fraudulent Ponzi schemes; others appear to have been the product of misplaced optimism and ignorant management. Usually it was difficult to tell which was which, and in any event the result was always the same. Those who got in early received stupendous returns, and those who came later seldom saw their money again. In 1883 the New York Superintendent of Insurance warned:

In every corner of the land great numbers of these scheming plans for money-making and personal aggrandizement are springing up and going among the people as life insurance associations under the plea of benevolent and charitable purposes. In many cases they are downright frauds, intended to rob the people. In many other cases they are wild and delusive schemes of crazy theorists, bubbles which are sure to burst.... [T] hey gather up vast sums of money from that class of our people who are least able to bear the drain, and carry it off to distant States, where the method of its expenditure is known to no one save those who receive and handle it. ${ }^{757}$

751 A Good Illustration, Fraternal MONITOR, Sept. I, I89o, at I4 (author's notes).

752 See id. (author's notes).

753 See 33 ANn. REP. Superintendent of the INS. DeP'T OF the STATE OF N.Y., pts. II-IV, at xxxv-xxxvi (Albany, James B. Lyon I892); 35 ANN. REP. SUPERINTENDENT OF THE INS. DEP'T OF THE STATE OF N.Y., pts. II-IV, at xxxvi (Albany, James B. Lyon I894).

754 See Advertisement, The Iron Hall, FRATERNAL MONITOR, Sept. I, I890, at I (author's notes).

755 See A Good Illustration, supra note 75 I, at I4 (author's notes).

756 See Advertisement, The Anti-Poverty Association of the Age, Fraternal MONITOR, Oct. I, I 890 , at I9 (author's notes).

75723 ANN. REP. SUPERINTENDENT OF THE INS. DEP'T OF THE STATE of N.Y., pt. I, at lx-lxi (Albany, Weed, Parsons \& Co. I882). 
"The pretenses and promises of some of the managers would be grotesque if they were not put forth in a serious way," wrote another insurance superintendent. ${ }^{758}$ The fraternal press lambasted endowment societies for approaching members "with the barefaced proposition that if "You will come in now, you will reap the advantage of being first." "759

Endowment orders appear to have had the most success recruiting members in Massachusetts, where they collected \$1 2.5 million from 364,000 members. Of this money collected, however, only about $\$ 3$ million was ever paid out to the holders of matured certificates. ${ }^{760}$ As many as fifty-six endowment corporations established themselves in Massachusetts; by I893, all fifty-six had collapsed, and the organizer of one of the largest - The Iron Hall - was under indictment. ${ }^{761}$

The flood of fraudulent and utopian schemes appears to have slowed by the mid-I 890 os as the first wave of five- to seven-year policies came due on which payments could not be made. The Iron Hall went into receivership in New York State in $1892,{ }^{762}$ and two years later Massachusetts banned endowment insurance contracts altogether. ${ }^{763}$ Many cooperative insurance associations resisted the lure of the endowment order schemes. ${ }^{764}$ But the episode had a permanent impact on the public perception of even the honest cooperative insurance associations. As late as I9I I, the New York State Department of Labor continued to monitor closely local fraternal organizations in immigrant communities to "weed[] out" fraud and to protect the "bona fide fraternal societies." 765

\section{E. The Failure of English-Style Collectivization}

I. The Quest for 'One National Organization.' - American cooperative insurance associations might have been able to reorganize themselves in the early twentieth century in such a way as to preserve their position as the nation's leading insurance mechanism. English friendly societies, after all, shared many of the traits of the American

758 See 26 ANN. REP. SUPERINTENDENT OF THE INS. DEP'T OF THE STATE OF N.Y., pt. II, at xxx (Albany, Weed, Parsons \& Co. I885).

759 Is It Time?, FRATERNAL MONITOR, Nov. I, I890, at 5 (author's notes).

760 See Cole, supra note 609, at 488; see also Bennett, supra note 750 , at 5 I 5 (discussing the height of endowment order popularity in Massachusetts).

76135 ANN. REP. SUPERINTENDENT OF THE INS. DeP'T OF THE STATE OF N.Y., pt. II, at xxxviii (Albany, James B. Lyon I894).

762 Glines v. Supreme Sitting of Order of Iron Hall, 2 I N.Y.S. 543, 544 (Gen. Term I892).

763 I 894 Mass. Acts 367.

764 See A Fraternal Beneficiary Society, FRATERnAL MONITOR, Jan. I, I895, at 7 (author's notes).

765 N.Y. ST. DEP'T OF LABOR, I9I I ANN. REP. BUREAU OF INDUS. \& IMMIGR. IOO. 
fraternals. ${ }^{766}$ Like the American cooperative self-insurance system, the friendly societies offered working-class members benefits in the event of accident, sickness, or death. And in the English case, the friendly societies managed to reform their practices to put their insurance pools on a sounder actuarial footing. Moreover, English friendly societies ultimately became a crucial building block in early British social insurance programs. In particular, friendly societies administered workingmen's health insurance under the National Insurance Act of I9I I, which required membership in a registered friendly society or another authorized insurer. ${ }^{767}$ Members and their employers paid mandatory premiums to the society; the society, in turn, paid the members' health care costs. ${ }^{768}$ Thus, as late as 1908, some students of workingmen's insurance in the United States thought it possible that the cooperative insurance societies might be integrated "into a great and powerful system covering the land."769

American cooperative insurance societies did indeed seek legislative change that would allow them to form a quasi-public, collectivized system of workingmen's insurance like the one established through the English friendly societies in I9I I. Beginning in I886, a number of the most important and well-established cooperative insurance associations - including the Ancient Order of United Workmen, the Knights of Honor, the Order of United American Mechanics, and the Royal Templars of Temperance - joined together to establish the National Fraternal Congress (NFC). ${ }^{770}$ From the start, the NFC's missions were to limit the entry of new fraternal associations into the field and to limit competition among existing associations for one another's younger and healthier members. ${ }^{771}$ The creation and enforcement of a standardized premium structure for all fraternal associations was a

\footnotetext{
766 See ABB LANDIS, FRIENDLY SOCIETIES AND FRATERNAL ORDERS 4-78 (I goo).

767 See Ogus, Great Britain, in THE EvOlution OF SOCIAL INSURANCE I88I-I98I: STUdies OF Germany, France, Great Britain, AUSTRIa AND SwitZERLAND 150, I85 (Peter A. Köhler $\&$ Hans F. Zacher eds., with Martin Partington, I982). The fact that by I9IO, many friendly societies were employer-managed relief funds rather than workingmen's self-insurance cooperatives somewhat complicates the story of the implementation of friendly societies into the national insurance scheme. See J.R. Hay, Employers' Attitudes to Social Policy and the Concept of 'Social Control', 1900-1920, in THE ORIGINS OF BRITISH SOCIAL POLICY 107, II9 (Pat Thane ed., I978). Moreover, last-minute changes to the National Insurance Act allowed commercial insurance companies to compete with the friendly societies as administrators. See RODGERS, supra note 74, at 233-34. The friendly societies, however, maintained their role as administrators of the National Health Insurance Act until the post-World War II reorganization of the English welfare state. See W.A. DINSDALE, HISTORY OF ACCIDENT INSURANCE IN GREAT BRITAIN I9-2 I (I954).

768 See A.I. Ogus, supra note 767 , at 150,185 .

769 HENDERSON, supra note 535, at 83; see also I.M. Rubinow, Labor Insurance, I 2 J. POL. ECON. 362, 362-63 (1904) (stating that "co-operative insurance" and the lodges of American fraternal associations "laid a foundation for future state universal insurance").

770 NFC JOURNAL OF PROCEEDINGS, supra note 728 , at I-3.

771 See id. at 38.
} 
critical part of these projects. Throughout the I8gos, the NFC encouraged member societies to revise their premium structures by moving away from the equal assessment basis and toward a premium rate that varied with the age of the member. ${ }^{772}$

As a private body, however, the NFC lacked the enforcement power necessary to prevent new societies from entering the market and offering lower rates to young members. As a result, the NFC was unable to control the unraveling tendencies of the cooperative insurance societies. Therefore, beginning in I 905 , the NFC sought uniform state legislation that would bar the entry of new societies offering premiums below the NFC's standard rates. ${ }^{773}$ By barring the entry of low-rate competitors, the NFC hoped to bring all new cooperative insurance association members into one of the existing societies. The influx of new members into the existing societies would keep rates low for older members. Moreover, the establishment of a fixed set of associations embracing all those seeking life and disability insurance through cooperative associations would stem the unraveling of the associations through the continual sorting and resorting of the membership into separate risk pools. Indeed, the uniform legislation movement sought to create nothing less than "one national organization" for the "welfare of the body politic" and "the welfare of each individual" therein. ${ }^{774}$

By I I I the NFC was able to report that thirteen state legislatures had enacted its proposed uniform bill setting rate standards and limiting the entry of new societies. ${ }^{775}$ The cooperationists' dream of creating "one national organization" for the collective self-insurance of its members, however, would never be realized. Beginning in 1908 and I909, the momentum in workingmen's insurance against accident shifted decisively away from the cooperative insurance associations.

2. The Failure of Collectivization. - (a) The Ideological Ambiguities of Cooperation. - Despite the leadership of the NFC, a persistent strand of voluntarism among many cooperationists divided the cooperative insurance movement over the questions of uniform legislation and barriers to entry. Thus, even as the NFC sought new regulations to stabilize the industry, many associations actively opposed new state regulation of cooperative insurance associations. ${ }^{776}$ Such opposition, of

772 See NAT'L Fraternal Cong., Report of the SPeCial Commission ON RATES, 2-8 (I899) (discussing several different plans); Meyer, supra note $47 \mathrm{I}$, at $65^{2}$.

773 See NAT'L FRATERNAL CONG., UNIFORM BILl RELATING TO FRATERNAL BENEFICIARY Associations 8-9 (I905).

774 One National Organization, FRATERNAL MONITOR, Apr. I, I9I 2, at 18 (author's notes).

775 NAT'L Fraternal CONGRESS, REP. OF JOHN J. HYNES, PRESIDENT, 7-8 (I 9 I I ).

776 See, e.g., Paternalism, Fraternal MONITOR, Feb. I, I89I, at I2 (author's notes) (arguing that the power of the state to effect social change is sharply limited and that "the government, either national or State, would be wise in diminishing rather than extending its functions in the direction of paternalism"). 
course, partly reflected the self-interest of upstart societies' leaders, whose leadership positions were threatened by limitations on the growth of new societies. ${ }^{777}$ But opposition to regulation also reflected the persistence of the voluntarist tradition in the cooperative insurance movement. The NFC thus experienced repeated difficulties controlling splinter coalitions opposed to its attempts to use uniform legislation to form a quasi-public body of cooperative insurance associations. ${ }^{778}$

(b) The Law of the Cooperative Insurance Contract. - Moreover, by the early twentieth century, developments in the law of insurance contracts made it increasingly difficult for cooperative insurance societies to police moral hazard and adverse selection problems. By the I 880 S and I89os, commercial life insurance companies had become extremely sophisticated in drafting life insurance policies. ${ }^{779}$ Commercial companies hired "able counsel" 780 to draft policies allowing them to deny claims on a variety of grounds, including voluntary assumption of increased risk, self-inflicted wounds, failure to maintain "sober and temperate habits," and death or disability from any number of causes that either posed risks of moral hazard or suggested the possibility of an undisclosed preexisting condition. ${ }^{781}$ Courts, however, reacted to insurance company drafting by interpreting insurance contracts contra proferentem - against the drafter - in all cases of ambiguity. ${ }^{782}$ In an ongoing dialectic between courts' interpretive decisions modifying apparently clear policy language in favor of sympathetic plaintiffs and insurance company lawyers' responses to those decisions, insurance contract litigation placed a premium on sophisticated policydrafting. ${ }^{783}$ Moreover, juries consistently favored plaintiffs in insur-

777 See, e.g., FRATERNAL MONITOR, Aug. I, I9I I, at I8 (author's notes) (recounting the Wisconsin Insurance Commissioner's efforts to assure the cooperatives that state insurance would not compete with cooperative insurance).

778 See, e.g., FRATERNAL MONITOR, Nov. I, I9I I, at 6 (author's notes) (discussing the split between the NFC and a competing group, Federated Fraternities).

779 See Contracts of Insurance, 3 U.L. REV. 297, 297 (I897).

780 Id.

781 Bliss, supra note 46, at I34-80; see DeXter Reynolds, TReatise on the LaW of Life AsSURANCE 85-II3 (Albany, Gould, Banks \& Co. 1853); William ReynoldS VANCE, HANDBOOK OF THE LAW OF INSURANCE 524-27 (I904); see also SPENCER L. KIMBALL, INSURANCE AND PUBLIC POLICY: A STUDY IN THE LEGAL IMPLEMENTATION OF SOCIAL AND ECONOMIC PUBLIC POLICY, BASED ON WISCONSIN RECORDS, I835-I959, at 2 I I (I960) (noting that company lawyers viewed contract drafting as a game to be played against the courts).

782 COOKE, supra note $46, \S 3$, at 3-4; VANCE, supra note 781, at 429-30.

783 For a discussion of insurance contract litigation in this period, see LAWRENCE $M$. Friedman, Contract LaW in AMERICA: A Social AND ECONOMiC CASE STUdY (1965); and FRIEDMAN, supra note 8, at 545-49. 
ance cases that pitted sympathetic claimants against deep-pocket insurance companies. ${ }^{784}$

Courts construed cooperative insurance contracts under the same interpretive principles applicable to commercial insurance policies. ${ }^{785}$ As in cases involving commercial companies, courts applied the doctrine of contra proferentem to cooperative policies. ${ }^{786}$ Yet cooperative insurance enterprises found themselves caught in the dialectic process of insurance contract writing and judicial interpretation without the legal acumen of the commercial insurers. ${ }^{787}$ Moreover, cooperative insurance agreements relied on broad and often vague standards to govern the conduct of associations and their members. Courts, however, insisted on a rule-bound construction of all insurance contracts, an approach that interpreted away all ambiguity. The result was two incommensurate approaches to insurance contract design and interpretation - one committed to standards and the other to rules. ${ }^{788}$ Not surprisingly, late nineteenth-century insurance lawyers thus observed that a disproportionate share of insurance litigation involved cooperative associations; as one insurance lawyer wrote, "the great mass of life insurance litigation arises on assessment certificates or policies."

784 See, e.g., William G. DAVIES, MYSTERIOUS DISAPPEARANCES AND PRESUMPTIONS OF DEATH IN INSURANCE CASES: Two PAPERS READ BEFORE THE NEW YORK MEDICO-LEGAL SOCIETY 9 (New York, L.W. Lawrence $188_{3}$ ) (observing the "tendency of the average jury to find a verdict against a life insurance company in all cases, without the slightest attention to the law or the facts involved"); FRIEDMAN, supra note 8, at 545-46.

785 Frederick H. BACON, A TREATISE ON THE LAW OF BENEFIT Societies AND INCIDENTALLY OF LIFE INSURANCE $§ 78$, at 94 (St. Louis, F.H. Thomas Law Book Co. I888) (explaining that "Benefit Societies doing a Life Insurance Business are like other Life Insurance Corporations" and that "[ $\mathrm{t}$ ]he contracts of all [cooperative or assessment companies] must be judged by the laws applicable to all similar contracts of other corporations").

786 See id. $\S 468$, at 704-05; CoOKE, supra note $46, \S 3$, at 3-4.

787 See Insurance Law as a Specialty, supra note 580, at 147-48 (ascribing high rates of cooperative insurance litigation to the cooperatives' reliance on lay persons to draft policies). Consider the example of the Maccabees' persistently frustrated policy-drafting. In I887 the Maccabees amended the disability provision of their bylaws. Under the new provision, a member was entitled to disability benefits if he became "unable to direct or perform the kind of business or labor which he has always followed, and by which alone he can thereafter earn a livelihood." Notwithstanding this restrictive language, at least one court required payment of disability benefits to a member who lost the fingers of his right hand while coupling railroad cars. Hutchinson v. Supreme Tent of Knights of Maccabees of the World, 22 N.Y.S. 80I, 80I-04 (Gen. Term I893). In response the Maccabees amended the disability provision again to provide disability benefits only to members unable "to perform or direct any kind of labor or business." Beach v. Supreme Tent of Knights of Maccabees of the World, 77 N.Y.S. 770, 77 I (App. Div. 1902) (quoting the defendant's bylaws) (emphasis added). Once again, however, courts defeated the Maccabees' own interpretation of their disability provision and held in favor of disabled members. Id. at 772, 775 (requiring payment of disability benefits to a member who lost the use of his right arm in a workplace sawmill accident, even though he could still direct and supervise work in the sawmill).

788 On rules versus standards, see Duncan Kennedy, Form and Substance in Private Law Adjudication, 89 HARV. L. REV. I685 (1976).

789 Insurance Law as a Specialty, supra note 580 , at 147. 
Moreover, cooperative insurers' special emphasis on policing moral hazard and adverse selection through medical examinations and strict codes of behavior made cooperatives less amenable to settlement than the commercial companies, and more likely to deny claims as well. 790 Yet courts placed restrictions and procedural limitations on the abilities of cooperative associations to amend their insurance provisions retroactively against existing members ${ }^{791}$ and to expel their members. ${ }^{792}$

By the first decade of the twentieth century, courts had thus severely hampered the effectiveness of the cooperatives' capacity to police for moral hazard and adverse selection. As a result, the cooperatives' special genius, which had allowed them to take a leading role in the provision of disability as well as life insurance in the late nineteenth century, came under increased pressure. Many associations in the late 1890 s and in the first decade of the twentieth century shifted their premium rates to a member-by-member basis in which rates sought to reflect the risk of a particular member, usually by the age of that member. ${ }^{793}$ And a number of societies exhibited new concerns about their inability to combat fraud and malingering by claimants. Cooperatives began to hire detective agencies to run background checks on prospective members and to investigate claims. ${ }^{794}$ Cooperative magazines ran regular columns alerting associations to particular kinds of fraud and particular repeat offenders in frauds on the cooperative societies. ${ }^{795}$

(c) The New Immigrants. - In addition, the massive influx of over one million new immigrants each year around the turn of the century radically changed the landscape of workingmen's insurance in the United States. ${ }^{796}$ New immigrants from Southern and Eastern Europe

\footnotetext{
790 The threat that settling cases would create incentives to manufacture claims would have been particularly acute for the cooperatives. Waltershausen suggested in his discussion of the cooperative insurance societies that some societies would themselves concoct reasons to expel members making long-term claims for permanent disability. WALTERSHAUSEN, supra note 86 , at 19293.

791 Amendment by a Mutual Benefit Society of Its Contract of Insurance, 37 CENT. L.J. 86, 87 (I893); see BACON, supra note 785 , § 92, at ro9-10. Significantly, the leading cases on retroactive amendment of benefits provisions were disability insurance cases, in which moral hazard issues were likely to be more of a problem than in life insurance cases. See id.

792 Expulsion of Members of Corporations and Societies, 24 AM. L. REV. 537, § 4, at 539-4I (I89o); see BACON, supra note 785 , §§ 95-I I I, at I I 3-40.

793 See Meyer, supra note $47 \mathrm{I}$, at 652.

794 See Advertisement, Thiel Detective Service Co., Fraternal MONITOR, Aug. I, IgI I, at 2 (author's notes).

795 See, e.g., Bogus Check Operations, Fraternal MONITOR, June I, I9I 2, at I5 (author's notes).

796 See generally JOHN BODNAR, THE TRANSPLANTED: A HISTORY OF IMMIGRANTS IN URBAN AMERICA I 20-30 (I985); OSCAR HANDLIN, THE UPROOTED: THE EPIC STORY OF THE GREAT MigRATIONS THAT MADE THE AMERICAN PEOPLE I 70-20I (I952).
} 
developed collective mutual protection societies of their own. ${ }^{797}$ Many such societies in immigrant communities, however, were never able to provide substantial benefits to workingmen or their families.

Indeed, it appears that as the influx of Eastern and Southern European immigrants accelerated, increasing numbers of American workingmen participated in small, local fraternal organizations in which death benefits provided families with only enough to pay for funeral expenses. The elite of the cooperative insurance associations, such as those that reported annually to state insurance commissioners, traditionally paid a death benefit of $\$ 1000$ or $\$ 2000 .^{798}$ Many mutual benefit associations, however, offered far less. Fifty-four percent of the families in the Wainwright Commission's study of work accidents in New York received some form of insurance benefit after the accidental death of a male wage-earner, but sixty percent of those receiving insurance benefits received less than $\$ 500 .{ }^{799}$ Similarly, in Chicago, a state commission found in 1918 that although four of five workingclass families had insured the life of at least one family member, most families' insurance policies were small: the average insurance policy in the Chicago study was for $\$ 419 .{ }^{800}$ Such policies ensured sufficient funds to pay for funeral costs, but they provided little more protection than that. As insurance expert E.H. Downey noted in the early I 920 , the insurance purchased by even the "better paid workmen" was "utterly inadequate as a permanent provision for a family which has lost its chief breadwinner." 801 In the grim words of one Polish mother in Chicago, the reasoning of those who worked to purchase insurance in the new immigrant communities was "[w]ork, work and earn for your grave." 802

By the middle of the first decade of the twentieth century, it was evident that the lowest-paid members of the working classes could not afford to insure themselves adequately against disability and death. In Pittsburgh only one in four working-class families possessed more than $\$ 500$ of insurance against death from industrial accident, and four of five of those families were from the upper half of the labor market. ${ }^{803}$

797 See, e.g., COHEN, supra note 725, at 64-72; SOYER, supra note 633, at 8I-I I 2.

$798 \mathrm{See}$, e.g., Hill, supra note 587 , at 2 (author's notes). In I89o the Ancient Order of United Workmen estimated that $\$ 2000$ in fraternal insurance cost $\$ 2$ I yearly. See id. (author's notes). One problem with the recent literature on fraternal associations as private alternatives to the welfare state is that it tends to analyze the well-funded elite fraternals and to draw conclusions from them about the entire movement. See, e.g., EMERY \& EMERY, supra note 486.

799 See FiRst REP. TO THE LEgIS. OF THE STATE OF N.Y. BY THE COMM'N APPOINTED UNDER CH. 5 I 8 OF THE LAWS OF I909 TO INQUIRE INTO THE QUESTION OF EMPLOYERS' LIABILITY AND OTHER MATTERS 26 (I9IO) [hereinafter WAINWRIGHT COMMISSION REPORT].

800 COHEN, supra note 725, at 65-66.

801 E.H. DOWNEY, WORKMEN'S COMPENSATION I 2 (I924).

802 COHEN, supra note 725 , at 65 .

803 See EASTMAN, supra note I64, at I34. 
In New York City Robert Coit Chapin of the Russell Sage Foundation found in 1909 that while I9I of 3 I8 working-class families purchased some kind of insurance, only 56 of them purchased life insurance in the amount of $\$ 500$ or more. ${ }^{804}$ Similarly, the Wainwright Commission, appointed in I909 to study work accidents in New York State, found that an appallingly low number of workingmen killed on the job had life insurance in any significant amount. ${ }^{805}$ Accordingly, the cooperative self-insurance approach to accident compensation seemed increasingly insufficient in many of the most compelling cases.

(d) The Transformation of Work, the Deterrence Problem, and the Decline of the First First-Party System. - The increased difficulties of combating moral hazard and adverse selection and the new influx of poor immigrants from Eastern and Southern Europe into the American workforce cannot entirely explain the decline of the cooperative insurance societies. After all, English-style collectivization could have swept the new immigrants and the working poor into state-mandated insurance societies and thus solved at least the adverse selection and unraveling problems by creating mandatory insurance pools.

A final force in the demise of the cooperative first-party insurance system was the dramatic reconceptualization and reorganization of work in America in the decade after I900. Work accidents lay at the heart of the turn-of-the-century accident problem. As a mechanism for compensating accident victims in the workplace, the first-party insurance system appears to have had many virtues. As a mechanism for encouraging safety and deterring accidents in the first place, however,

804 ChAPIN, supra note 535, at I9I-92. A similar study in Buffalo found similar results. See John R. Howard, Jr., Report on the Standard of Living Among Workingmen's Families in Buffalo, New York, in CHAPIN, supra note 535, app. 5, at 307, 310.

805 WAINWRIGHT COMMISSION REPORT, supra note 799, at 26.

TABLE 4. INSURANCE PAYMENTS TO MEN KILLED IN INDUSTRIAL ACCIDENTS, ERIE COUNTY, NEW YORK, DURING I907 AND I 908 , AND IN MANHATTAN DURING I 908 , BY WAGES

\begin{tabular}{|c|c|c|c|c|c|c|c|c|c|}
\hline \multirow{3}{*}{$\begin{array}{l}\text { Weekly } \\
\text { Wage }\end{array}$} & \multirow[t]{3}{*}{ Total } & \multicolumn{8}{|c|}{ Insurance Recovered } \\
\hline & & \multicolumn{2}{|c|}{$\$ 0$} & \multicolumn{2}{|c|}{$\$ I-499$} & \multicolumn{2}{|c|}{$\$ 500-999$} & \multicolumn{2}{|c|}{$\$ 1,000$ and over } \\
\hline & & No. & $\%$ & No. & $\%$ & No. & $\%$ & No. & $\%$ \\
\hline $\begin{array}{l}\text { Less than } \\
\$ 9\end{array}$ & I3 & 7 & 53.8 & 5 & 38.4 & I & 7.7 & - & - \\
\hline$\$ 9-$ I I.99 & 37 & 17 & 45.9 & I3 & 35.1 & 6 & I6.2 & $\mathrm{I}$ & 2.7 \\
\hline $\begin{array}{l}\$ 12- \\
15.99\end{array}$ & 77 & 48 & 62.3 & I6 & 20.7 & 3 & 3.8 & Io & 12.9 \\
\hline $\begin{array}{l}\$ 16- \\
20.99\end{array}$ & 44 & I6 & 36.3 & I7 & 38.6 & 4 & 9.0 & 7 & I5.9 \\
\hline $\begin{array}{l}\text { \$2 I and } \\
\text { over }\end{array}$ & 40 & 9 & 22.5 & I7 & 42.5 & 5 & I 2.5 & 9 & 22.5 \\
\hline Totals & 2 II & 97 & 45.9 & 68 & 32.2 & I9 & 9.0 & 27 & 12.7 \\
\hline
\end{tabular}

Id. at 26. 
first-party insurance relied on one of two assumptions. First, the success of cooperative self-insurance depended in part on the idea that workers themselves acted as effective agents in the administration of an accident law regime. Thus, for example, the mid-nineteenthcentury law of employers' liability rested on the claim - often inaccurate - that workers themselves were largely in control of the operations of the industrial workplace and therefore were the most effective preventers of work accidents. ${ }^{806}$ Lemuel Shaw and other judges elaborating and applying the rules of employers' liability argued that workers rather than employers were in the best position to prevent accidents. ${ }^{807}$ Moreover, sophisticated working-class advocates of firstparty insurance argued that self-insurance among workingmen held the promise of allowing workers to impose the costs of work accidents on employers. Workingmen who banded together to create mutual insurance programs, the argument went, would come to expect higher wages and would acquire the collective power to exact those higher wages from employers. ${ }^{808}$

Second, first-party approaches to accident law could also effectively address safety concerns and deter accidents if accompanied by a regulatory system that effectively enforced safety measures in workplaces. ${ }^{809}$ By the first decade of the twentieth century, however, state factory inspection regimes in the United States were seen as clear failures. ${ }^{810}$ In New York, for example, the 1886 factory inspector law, as amended in 1887 , sought to protect the "life or limbs" of factory employees by requiring employers to cover hoisting shafts and elevator openings, to build fire escapes for factories higher than three stories, and to install handrails and rubber skid-proof mats on all flights of stairs. The statute also required safeguards for belts and gears and mandated that employers report all workplace injuries to the state factory inspector. ${ }^{811}$ But persistent enforcement problems rendered the statute ineffective from the start. Fines of $\$ 50$ to $\$ 100$ were simply too small to induce compliance by many employers. ${ }^{812}$ Moreover, in the

806 See Witt, supra note 695, at $1469-84$.

807 See id. at $1469-70$.

808 See supra p. 795.

809 Today's accident law literature commonly makes the point that first-party or social insurance approaches require supplementary command-and-control deterrence and safety regulations. See, e.g., CALABRESI, supra note 9, at 284-85.

810 See, e.g., GRAEBNER, supra note 699 , at 72-I I I. The highly successful I 893 federal legislation requiring automatic couplers was a rare exception to the general failure of regulatory control. See ALDRICH, supra note $\mathrm{I} 3$, at 37. Other federal railroad safety requirements such as the air brake had mixed effects on railroad accident rates, because air brakes allowed railroad companies to increase the length and speed of their trains. See id. at 38 .

811 Ch. 409, §§ 9, I I, I886 N.Y. Laws 629, amended by ch. 576, § 2, I887 N.Y. Laws 575, 576.

812 See R. Rudy Higgens-Evenson, From Industrial Police to Workmen's Compensation: Public Policy and Industrial Accidents in New York, r880-rgro, 39 LAB. HIST. 365, 369-70 (I998). Cf. 
I 890 s and early igoos, the severely understaffed New York Factory Inspector's office typically issued tens of thousands of compliance orders to noncomplying employers each year but exacted only \$1000 to $\$ 2000$ in fines annually. 813 By I909, when the Wainwright Commission surveyed the industrial accident problem in the State of New York, few believed that the factory inspectors could effectively regulate industrial safety. 814

If regulatory approaches to making the workplace safer were unworkable, the ability of workers themselves to act as effective agents of accident prevention became critical to the continued centrality of first-party cooperative insurance in American accident law. So long as workers in many of the most dangerous industries exercised relative autonomy in the workplace, the safety incentives argument could plausibly be said to point toward placing the costs of accidents - and thus the incentives to avoid accidents - on employees. ${ }^{815}$ But if prescriptive ideas about how best to organize work changed, and if the organization of work itself changed in the American workplace, the deterrence argument would point the other way.

In the first decades of the twentieth century, the new prominence in the industrial safety debate of expanded employers' liability rules and workmen's compensation at once signaled and reproduced dramatic changes in the organization of the American workplace. Led by Frederick Winslow Taylor and his gospel of "scientific management," managerial experts in labor relations and in the organization of production processes assumed central roles in the American economy. In view of the reorganization of the workplace, contemporaries began to focus not merely on the incentive effects of liability rules on the workers themselves - as Shaw and other mid-nineteenth-century judges had - but rather on the poor incentives that the law of employers' liability created for employers to ensure workplace safety. ${ }^{816}$ The Wainwright Commission, for example, believed that the best way to have "a real effect" in making employers focus on work safety was not to increase the state's regulatory apparatus, but to place the economic cost of work accidents on the employer, thereby "making him put his

Donald W. Rogers, From Common Law to Factory Laws: The Transformation of Workplace Safety Law in Wisconsin Before Progressivism, 39 AM. J. LEGAL HIST. I77, 196-208 (1995) (describing the enforcement problems of industrial regulation in Wisconsin).

813 See WAINWRIGHT COMMISSION REPORT, supra note 799, at 6; Higgens-Evenson, supra note $8 \mathrm{I} 2$, at $37 \mathrm{I}$; $f$. Rogers, supra note $8 \mathrm{I} 2$, at 202 (describing Wisconsin's understaffed inspector offices).

814 See WAINWRIGHT COMMISSION REPORT, supra note 799, at 6.

815 Even if workers insured against such costs, their interest in self-preservation provided considerable incentives for deterrence.

816 See, $\rightarrow$ Woods, supra note $\mathrm{I} 33$, at 316-I 7 . 
mind constantly to the question of preventing accidents." ${ }^{17}$ Meanwhile, students of social insurance began increasingly to doubt the capacity of workingmen themselves to gauge the risk of accidents and to insure themselves accordingly. "[E]very man," it was said, "depreciates the risk of his peculiar calling. The car-coupler, the laborer on a construction train, or the electric-light lineman, is perfectly sure that there is no occupation safer than the one in which he is engaged." ${ }^{18}$

\section{Conclusion: A PATH Not TAKEN}

Given that the cooperative insurance associations faced mounting problems in the first decade of the twentieth century, how is it that they represent (as I have claimed) a viable path not taken in the development of American accident law? It is, after all, exceedingly difficult to imagine the lodges and fraternal rituals of the cooperatives surviving on a widespread basis through the twentieth century.

The key to understanding the long-term significance of the cooperatives as an alternative in the development of American accident law is that in other Western nations, insurance associations of one kind or another helped build twentieth-century social insurance programs. Systems of social insurance play a more important role in compensating accident victims in Western Europe than they do in the United States. And in Western Europe, nineteenth-century systems of workingmen's insurance became crucial intermediaries in the construction of twentieth-century social insurance programs. State-run social insurance programs require an infrastructure, and the need to construct a bureaucratic apparatus can be a considerable obstacle to the development of new state systems of insurance.

As the English example makes clear, cooperative workingmen's associations in the United States could have adapted to serve new and important functions in the twentieth century. In Great Britain, after all, friendly societies administered state insurance programs under the I 9 I I National Insurance Act, accepting contributions from members and their employers and administering benefit claims. Indeed, the friendly societies continued to play an important role in the administration of the national welfare state until World War II. Similarly, in Germany, the social insurance legislation of the I880s arose out of a welter of local and regional insurance programs, some compulsory and others voluntary.

\footnotetext{
817 WAINWRIGHT COMMISSION REPORT, supra note 799, at 7.

818 James R. Pitcher, Accidents and Accident Insurance, I2 FORUM I3I, I34 (189I). This psychological tendency toward overly optimistic assessments of risk (the "cognitive bias" toward optimism, in the language of behavioral science) remains to this day one of the central justifications for workers' compensation programs. See, e.g., CALABRESI, supra note 9, at 245.
} 
Some students of workingmen's insurance believed that the American cooperatives would, like their English counterparts, help to create a broad system of social insurance. ${ }^{819}$ In the United States, however, social insurance reformers did not begin to propose broad social insurance programs until around i9io. And by that time, developments such as mass immigration and the reorganization of the workplace developments uniquely powerful in the United States - meant that cooperative insurance seemed increasingly out of step with twentiethcentury conditions. Indeed, they seemed unable to fulfill their compensation function and inadequate as a means of deterring work accidents in the first place. As a result, the cooperative insurance associations dropped out of American reform debates just as social insurance reform proposals arrived on the legislative agenda.

Total cooperative life and disability insurance in force as a percentage of commercial life insurance in force fell from $137 \%$ in 1895 to $109 \%$ in 1900 to roughly $99 \%$ in 1905.820 In the wake of the enactment of workmen's compensation statutes in virtually every important industrial jurisdiction in the decade after I9Io, the importance of cooperative insurance associations declined still more rapidly. Cooperative life and disability insurance in force as a percentage of commercial life insurance in force fell sharply to $4 \mathrm{I} \%$ by $\mathrm{I} 9 \mathrm{I} 6$ and then to $23 \%$ by 1920.821 As shown in the table below, cooperative life insurance in force per capita in the United States fell from an all-time high of \$105 in I 910 to just $\$ 37$ in 1920 after adjusting for wartime inflation. 


\section{TABle 5. Life Insurance in Force Per Capita in THE UNITED STATES, IN CONSTANT I 890 DOllarS $^{822}$}

\begin{tabular}{|l|l|l|}
\hline Year & Cooperative & $\begin{array}{l}\text { Commercial } \\
\text { (stock and mutual combined) }\end{array}$ \\
\hline $\mathrm{I} 885$ & $\$ 39.32$ & $42.4 \mathrm{I}$ \\
\hline $\mathrm{I} 890$ & 58.10 & 54.09 \\
\hline $\mathrm{I} 900$ & 93.83 & 86.00 \\
\hline $\mathrm{I} 910$ & 104.99 & 98.85 \\
\hline $\mathrm{I} 920$ & 37.09 & 93.76 \\
\hline 1925 & 45.72 & 173.92 \\
\hline
\end{tabular}

More dramatically still, the relative financial importance of cooperative insurance to the average family enrolled in an insurance society decreased sharply after I900, and especially after I9I0. Measured in constant I89os dollars, the average size of a cooperative life insurance policy fell from $\$ 1362$ in 1900 to $\$ 873$ in 1910 to a mere $\$ 368$ in 1920.823

Moreover, actuarial reform drained the cooperatives of their distinct practices and cooperative ethos. By the I 920 s even those who continued to play a leadership role in fraternal insurance associations saw them as little different from commercial life insurance companies. ${ }^{824}$ No longer did the cooperatives play the special role among American insurers of insuring workingmen against the risk of disabil-

822 I derived the figures in the table as follows:

(I) I obtained the amount of each type of insurance from its respective source. For cooperative insurance figures, see $i d$. For ordinary commercial insurance figures, see 72 ANN. REP. SUPERINTENDENT OF THE INS. DEP'T OF THE STATE OF N.Y., pt. II, at xxiii (I93I).

(2) To correct for underreporting, I adjusted the cooperative insurance figures upward by twenty percent, as recommended in STALSON, supra note 469 , at 806 app. I 8.

(3) I adjusted for inflation by reference to the "Douglas" price index. See I Historical STATISTICS OF THE UNITED STATES, supra note $\mathrm{I}_{75}$, at $2 \mathrm{I} 3$. The Douglas price index does not go as far back as $\mathrm{I} 885$, so I estimated the Douglas index for I885 by comparison to the "Burgess" index. See id. I compared Burgess I9I3 (value $=100$ ) to Douglas I9I3 (value $=137$ ) and extrapolated backward to conclude that if Burgess $1885=64.6$, then Douglas $1885=88.5$. The algebra is $100 / 137=64.6 / x$.

(4) I then divided by population figures taken from HISTORICAL STATISTICS OF THE UNITED States: Two Centuries of The Census, I 790-1990, at I04 (Donald B. Dodd ed., I993). To calculate population figures for the midpoints between decades, I assumed constant population change within each decade.

823 I arrived at these amounts by dividing the total dollar amount of life insurance by the number of certificates for each year, see STALSON, supra note 469 , at 807 app. I9, and then adjusting for price inflation using the Douglas price index, see I HISTORICAL STATISTICS OF THE UNITED STATES, supra note I 75 , at 2 I 3 .

824 See, e.g., FRATERNAL LIFE INSURANCE, supra note 613, at 30 (explaining that in the old days "[t]here was no discrimination on account of age or physical condition or occupation. It was true equality and fraternity"). 
ity as well as death. And to the extent that cooperative insurance associations continued to insure families of modest means against the death of a wage-earner, they did so in ways not very different from those of commercial insurers.

The failure of the first American first-party system to go the way of the English friendly societies helped shape the basic institutional features of American accident law in the twentieth century. In the United States social insurance systems for accident compensation remain relatively limited outside the field of work accidents. Not coincidentally, American accident law in our own time is characterized by a high dependence on tort litigation relative to other Western nations. ${ }^{825}$ Accident victims in the United States are more likely than their English counterparts to file personal injury tort claims. ${ }^{826}$ Comparative studies indicate that injured Americans file roughly 327 tort suits per 100,000 people, whereas injury victims in England and Wales file only i 7 tort suits per 100,000 people. ${ }^{827}$ Moreover, Americans are more likely than the English and Welsh to consider claiming damages in the event of nonwork accidents, and studies suggest (though inconclusively) that they are also more likely to consult a lawyer. ${ }^{828}$

Of course, the failure of the first-party insurance system cannot in and of itself explain the peculiarities of the American law of accidents. The availability of juries in American personal injury actions, the English attorney's fee rule that places the burden of the winner's legal costs on the loser, and any number of other differences between American and European accident law regimes have played important roles.

Nonetheless, if the cooperative insurance associations' relative unimportance in the twentieth century has blinded us to the important role they played in the late nineteenth century, it bears repeating that the cooperative insurance societies of the 1880 s and 1890 s presented a very real alternative to the kind of accident law regime that eventually

825 See, e.g., George L. Priest, Compensation for Injury in the United States, in COMPENSATION FOR PERSONAL INJURY IN SWEDEN AND OTHER COUNTRIES I 27 , I38 (Carl Oldertz \& Eva Tidefelt eds., I 988 ).

826 To be sure, in neither the United States nor England does the tort system provide compensation to more than a small minority of accident victims. Just $6.5 \%$ of English accident victims receiving compensation for their injuries did so through the tort system. See REPORT OF THE ROYAL COMMISSION ON CIVIL LIABILITY AND COMPENSATION FOR PERSONAL INJURY I3 tbl.4 (I978). Meanwhile, $10.5 \%$ of American accidental injury victims receiving compensation did so through the tort system, including settlements. See COMPENSATION FOR ACCIDENTAL INJURIES, supra note I I6, at IoI.

827 See Richard A. Posner, Explaining the Variance in the Number of Tort Suits Across U.S. States and Between the United States and England, 26 J. LEGAL STUD. 477, 478-79 (1997).

828 See COMPENSATION FOR ACCIDENTAL INJURIES, supra note II6, at I27-29. The data are different for work accidents because British workers injured on the job are able to bring tort actions against their employers, whereas similarly situated Americans are not. 
developed in the twentieth century. To be sure, the first-party system of the late nineteenth century had its difficulties. Twenty-first century supporters of first-party approaches to accident law would do well to note the extent to which problems of moral hazard and adverse selection plagued their late nineteenth-century precursors. ${ }^{829}$ Yet the ultimate unraveling of the nineteenth-century cooperative insurance regime hardly indicates that the cooperative insurance associations had nothing to offer in the twentieth century. In a more hospitable legal climate that allowed the societies to combat adverse selection and moral hazard more actively and that preserved significant worker discretion in the production process, the nineteenth-century first-party insurance system might have changed the face of accident law into the early twentieth century.

Regardless of the precise long-term implications of the cooperative accident insurance movement, the story of the cooperative insurance societies suggests that the history of American accident law is considerably richer and more variegated than most accounts of tort law suggest. At the turn of the twentieth century, accidents and accident law became perhaps the most visible manifestations of the wrenching difficulty of accommodating nineteenth-century free labor ideals to the world of mass industrial production. In response to rising industrial accident rates, a wide array of Americans - ranging from workingmen and labor leaders to judges, lawyers, and scholars - experimented with an equally wide array of approaches to understanding and resolving the accident crisis. In particular, the contest between classical tort law and cooperative accident insurance embodied two contrasting conceptions of how best to reorganize the nation for a new age.

Ultimately, of course, neither classical tort law's liberalism nor the insurance societies' cooperative commonwealth emerged completely victorious. The cooperatives declined and failed, and administrative state programs replaced much of the common law in the first decades of the twentieth century; beginning in the I9Ios, state workmen's compensation statutes removed the most significant class of cases from tort law altogether. ${ }^{830}$ Nonetheless, the turn-of-the-century struggle to

829 Cf. Hanson \& Logue, supra note 48I (arguing that, because of moral hazard and adverse selection problems, first-party insurance systems are in many instances inferior to enterprise liability supplemented by third-party liability insurance). First-party systems are especially vulnerable to problems of moral hazard and adverse selection, with the prominent exception of automobile insurance - in which insureds' driving records may provide insurers with sufficient information to risk-rate. The automobile case is generally the favorite example for supporters of first-party systems. See, e.g., Priest, Current Insurance Crisis, supra note I, at I558.

830 See, e.g., Workmen's Compensation Law, ch. 816, I913 N.Y. Laws 2277 (abolishing the negligence action for injured employees against their employers and replacing it with a no-fault administrative compensation scheme). 
address the accident problem had lasting consequences for the shape of American accident law in the twentieth century.

Indeed, it is not too far-fetched to suggest that at the turn of a new century, we find ourselves in a not dissimilar position. As massive class actions, toxic torts, and complex litigation push tort law into uncharted territory, we too will have to ask hard questions about what we want from our accident law regime. And, as in I900, it seems likely that the choices we make will have lasting consequences for the shape of American accident law in the century to come. 